\begin{tabular}{|l|l|}
\hline 2. To: (Receiving organization) & 3. From: (Originating Organization) \\
Distribution & Numatec Hanford Corporation \\
\hline 5. Proj./Prog./Dept./Div.: & 6. Design Authority/ Design Agent/Cog. \\
Hanford Tanks Initiative & D. L.: Becker \\
\hline
\end{tabular}

8. Originator Remarks:

This document is being released into the Supporting Document system.
11. Receiver Remarks:
11A. Design Basel ine Document?
[] Yes [X] No

For Release.

\section{Related EDT No.: \\ $\mathrm{N} / \mathrm{A}$}

7. Purchase order No.:

$\mathrm{N} / \mathrm{A}$

9. Equip./Component No.:

$\mathrm{N} / \mathrm{A}$

10. System/Bldg./Facility:

$$
\mathrm{N} / \mathrm{A}
$$

12. Major Assn. Dwg. No.:

$\mathrm{N} / \mathrm{A}$

13. Permit/Permit Application No.: $N / A$

14. Required Response Date: $N / A$

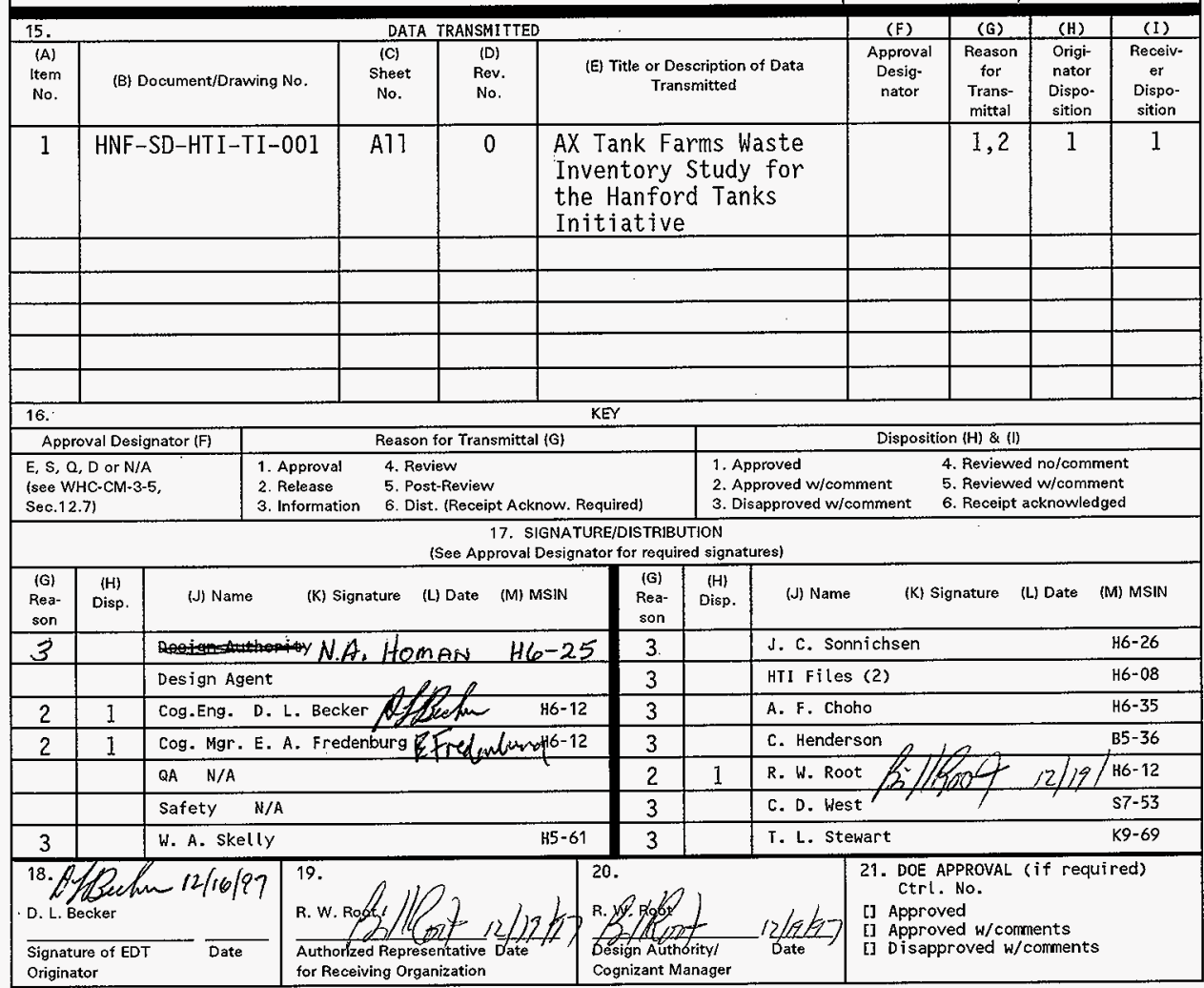




\title{
AX Tank Farm Waste Inventory Study for The Hanford Tanks Initiative Project
}

\author{
D. L. Becker, (SESC - D. W. Hendrickbłson, T. W. Staehr, \\ S. L. Lambert, D. C. Ramsower) \\ Numatec Hanford Corporation, Richland, WA 99352 \\ U.S. Department of Energy Contract DE-ACO6-96RL13200
}

$\begin{array}{ll}\text { EDT/ECN: } 622810 & \text { UC: UC-510 } \\ \text { Org Code: } 8 C 452 & \text { Charge Code: }-226 E 1-\text { D25ET } \\ \text { B\&R Code: EW3130010 } & \text { Total Pages: } 225 \text { fs }\end{array}$

Key Words: Waste Inventory Study, Ax Tank Farm

Abstract: ' In May of 1996, the U. S. Department of Energy implemented a four-year demonstration project identified as the Hanford Tanks Initiative (HTI). The HTI mission is to minimize technical uncertainties and programatic risks by conducting demonstrations to characterize and remove tank waste using technologies and methods that will be needed in the future to carry out tank waste remediation and tank farm closure at the Hanford site. Included in the HTI scope is the development of retrieval performance evaluation criteria supporting readiness to close single-shell tanks in the future. A path forward that includes evaluation of closure basis alternatives has been out lined to support the development of retrieval performance evaluation criteria for the AX Farm, and eventual preparation of the SEIS for AX Farm closure. This report documents the results of the Task 4, Waste Inventory, study performed to establ ish the best-bas is inventory of waste contaminants for the AX Farm, provides a means of estimating future soil inventories, and provides data for estimating the nature and extent of contamination (radionuclide and chemical) resulting from residual tank waste subsequent to retrieval. Included in the report are a best-basis estimate of the existing radionuclide and chemical inventory in the AX Farm Tanks, an estimate of the nature and extent of existing radiological and chemical contamination from past leaks, a best-basis estimate of the radionuclide and chemical inventory in the AX Farm Tanks after retrieval of 90 percent, 99 percent, and 99.9 percent of the waste, and an estimate of the nature and extent of radionuclide and chemical contamination resulting from retrieval of waste for an assumed $30.2 \mathrm{m3}$ ( $8 \mathrm{kgal}$ ) and $151 . \mathrm{m} 3$ (40 kgal) leakage from the tanks during retrieval.

TRADEMARK DISCLAIMER. Reference herein to any specific commercial product, process, or service by trade name, trademark, manufacturer, or otherwise, does not necessarily constitute or imply its endorsement, recommendation, or favoring by the United States Government or any agency thereof or its contractors or subcontractors.

Printed in the United States of America. To obtain copies of this document, contact: Document Control Services, P.O. Box 950, Mailstop H6-08, Richland WA 99352, Phone (509) 372-2420; Fax (509) 376-4989.
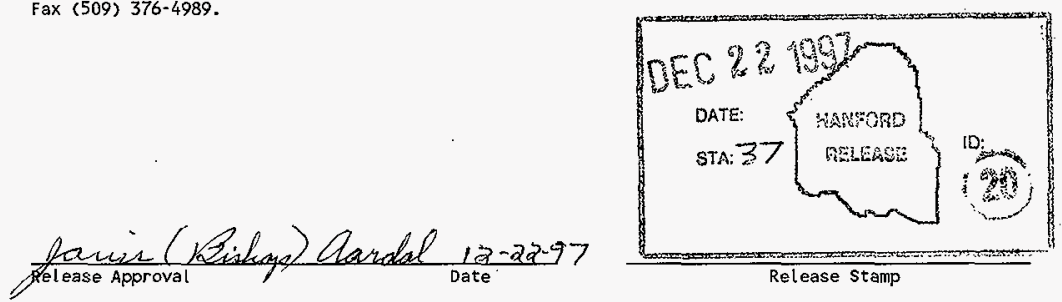

Release stamp

\section{Approved for Public Release}


HNF-SD-HTI-TI-001, Rev. 0

The current $A X$ Tank waste volume inventory estimates reported in this document were used as input for developing the Hanford best-basis tank inventory estimates reported in Kupfer et al. 1997, Hendrickson and Herting 1997, Hendrickson and Lambert 1997a, Hendrickson and Lambert 1997b, and Hendrickson et a1. 1997. Estimates of AX Tank waste inventories reported in this document may differ in some cases from the Hanford best-basis tank inventory estimates given in the referenced documents (Kupfer et al. 1997, Hendrickson and Herting 1997, Hendrickson and Lambert 1997a, Hendrickson and Lambert 1997b, and Hendrickson et a 1. 1997) due to refinements in the latter during preparation and finalization. The reader is advised to refer to the referenced documents (Kupfer et a1. 1997, Hendrickson and Herting 1997, Hendrickson and Lambert 1997a, Hendrickson and Lambert 1997b, and Hendrickson et a1. 1997), and subsequent revisions thereof, for best-basis estimates of current waste inventories in AX Farm Tanks. Results in this report are intended on fy for the purpose of evaluating retrieval and closure alternatives for the AX Farm.

In preparation of this document consideration was given to: (1) el iminating the water source term correction from the supernate mixing model for determining the salt cake in tank. 241-A-102, which was then used as a reference basis for determining the salt cake in Tanks 241-AX-101, - 102, and $103,(2)$ eliminating analytical adjustments for $\mathrm{Fe}, \mathrm{Ni}, \mathrm{CO}_{3}$ and $\mathrm{Si}$ in the 241AX-102 data, (3) correcting the best-basis $\mathrm{OH}$ estimate so that this estimate is consistent with the expanded list of analytes used in the HII study (including $\mathrm{Ag}, \mathrm{As}, \mathrm{B}, \mathrm{Ba}, \mathrm{Cd}, \mathrm{Cu}, \mathrm{Mg}$, $\mathrm{Se}, \mathrm{Zn}, \mathrm{EDTA}, \mathrm{NH}_{4}, \mathrm{Cr}^{+6}, \mathrm{CN}$ and $\mathrm{H}_{2} \mathrm{O}$ ), (4) accounting for the appropriate decay date (12/31/99) for all radionuclides, (5) basing the uranium inventory on the activities of its isotopes when referred to the Hanford Defined Waste mode 7 inventory, and (6) assessing the affect of the revised $K$ inventory on the previous leakage estimates for Tank 241-AX-104. This list of considerations has been submitted for incorporation into the Hanford best-basis inventories for AX Tanks. Accordingly, this document also includes additional data on the expanded list of analytes of importance to the HTI evaluations.

Attachments to letter SESC-97-646 have been incorporated into this document.

References:

Hendrickson, D. W. and D. L. Herting, 1997, Tank Characterization Report for Single She77 Tank 241-AX-102 [Appendix I], WHC-SD-WM-ER-472, SGN Eurisys Services Corporation for Fluor Daniel Hanford Company, Richland, Washington.

Hendrickson, D. W. and S. L. Lambert, 1997a, Preliminary Tank Characterization Report for Single She77 Tank 241-AX-104, Best Basis Inventory, HNF-SD-WM-ER-675, SGN Eurisys Services Corporation for Fluor Daniel Hanford Company, Richland, Washington.

Hendrickson, D. W. and S. L. Lambert, 1997b, Pre7iminary Tank Characterization Report for single Shell Tank 241-AX-103, Best Basis Inventory, HNF-SD-WM-ER-685, SGN Eurisys Services Corporation for Fluor Daniel Hanford Company, Richland, Washington. 
Hendrickson, D. W., D. E. Place and B. A. Higley, 1997, Preliminary Tank Characterization Report for Single Shel7 Tank 241-AX-101, Best Basis Inventory, HNF-SD-WM-ER-649, SGN Eurisys Services Corporation for Fluor Daniel Hanford Company, Richland, Washington.

Kupfer, M. J., A. L. Boldt, B. A. Higley, K. M. Hodgson, L. W. Shelton, R. A. Watrous, S. L. Lambert, D. E. Place, R. M. Orme, G. L. Borsheim, N. G. Colton, M. D. LeClair, R. T. Winward and W. W. Schulz, 1977, Standard Inventories of Chemicals and Radionuclides in Hanford Site Tank Wastes, HNF-SD-WM-TI-740, Lockheed Martin Hanford Corporation for FTuor Daniel Hanford Company, Richland, Washington. 
$1.0 \quad$ INTRODUCTION $\ldots \ldots \ldots \ldots \ldots \ldots \ldots \ldots \ldots \ldots \ldots \ldots \ldots \ldots \ldots \ldots$

$2.0 \quad 241$-AX TANK FARM DESCRIPTION AND HISTORY $\ldots \ldots \ldots \ldots \ldots \ldots \ldots$

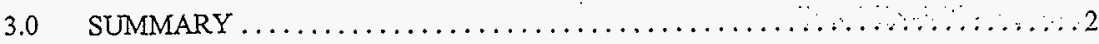

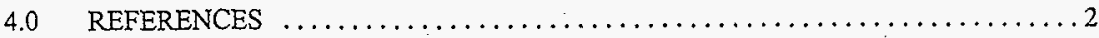

APPENDICES:

A - A SUMMARY OF LEAKS AND SPILLS CONTRIBUTING TO AX TANK FARM VADOSE ZONE CONTAMINATION.$\ldots \ldots \ldots \ldots \ldots \ldots \ldots \ldots \ldots \ldots \ldots \ldots$ A-i

B - BEST-BASIS INVENTORY, RETRIEVAL INVENTORY, AND LEAKAGE INVENTORY ESTMMATES FOR RETRIEVAL OF WASTE FROM SINGLE-SHELL

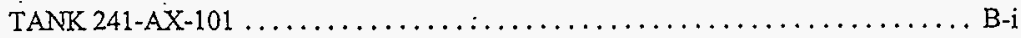

C - BEST-BASIS INVENTORY, RETRIEVAL INVENTORY, AND LEAKAGE INVENTORY ESTIMATES FOR RETRIEVAI OF WASTE FROM SINGLE-SHELL TANK 241-AX-102

D - BEST-BASIS INVENTORY, RETRIEVAL INVENTORY, AND LEAKAGE INVENTORY ESTIMATES FOR RETRIEVAL OF WASTE FROM SINGLE-SHELL TANK 241-AX-103 $\mathrm{D}-\mathrm{i}$

E - BEST-BASIS INVENTORY, RETRIEVAL INVENTORY, AND LEAKAGE INVENTORY ESTIMATES FOR RETRIEVAL OF WASTE FROM SINGLE-SHELI TANK 241 -AX-104 $\ldots \ldots \ldots \ldots \ldots \ldots \ldots \ldots \ldots \ldots \ldots$ E-i

F - REPORT OF BEST-ESTIMATE PAST RELEASE VADOSE ZONE CONTAMINATION OF THE 241-AX TANK FARM $F-i$ 


\subsection{INTRODUCTION}

This study establishes the best-basis waste contaminates inventory for the 241-AX Tank Farm. The purpose is to provide a means of estimating future soil inventories, and the nature and extent of contamination (radioactive and chemical) resulting from residual waste once the waste has been removed (retrieved) from the tanks. The data provided will be used to develop the retrieval reformanre evaluation criteria for the Hanford Tanks Initiative.

The data presented will provide the following information:

- A best-basis estimate of the existing radionuclide and chemical inventory in the 241-AX Tank Farms.

- An estimate of the nature and extent of existing radiological and chemical contamination from past leaks.

- A best-basis estimate of the radionuclide and chemical inventory in the 241-AX Tank Farms after retrieval of 90 percent of the waste, retrieval of 99 percent of the waste, and retrieval of 99.9 percent of the waste.

- An estimate of the nature and extent of radionuclide and chemical contamination resulting from retrieval of waste for an assumed $30.2 \mathrm{~m}^{3}(8 \mathrm{kgal})$ and $151.4 \mathrm{~m}^{3}(40 \mathrm{kgal})$ leakage from the tanks.

\subsection{1-AX TANK FARM DESCRIPTION AND HISTORY}

The 241-AX Tank Farm, the fifth and final generation of single-shell tanks (SST) built at Hanford, is located in the East Tank Farm area north of the A Tank Farm, east of Buffalo Avenue and west of Canton Avenue. They were placed in service in 1966. The farm consists of four 100 series, $3.785 \times 10^{3} \mathrm{~m}^{3}(1,000,000 \mathrm{gal}), 22.8 \mathrm{~m}$ ( $\left.75 \mathrm{ft}\right)$ dianieter SST with no cascade overflow lines between the tanks. The tanks were designed for PUREX and $B$ Plant aging waste, which is boiling or self-concentrating with a minimum fluid temperature of $121.1^{\circ} \mathrm{C}\left(250^{\circ} \mathrm{F}\right)$ and a boiling period of five to ten years. The $\mathrm{AX}$ tanks were sluiced in the early 1970 s to reduce the amount of heat generating strontium and cesium. Tanks AX-10,102, and 103 were sluiced to a small heel and released to a saltcake waste receiver. In 1977, Tank AX-104 was found to be leaking and was removed from service. Tank AX-102 was deactivated in 1980 and declared an assumed leaker in 1988. The two remaining tanks were also removed from service in 1980 but are categorized as sound. 


\subsection{SUMMARY}

The results of this study are presented in six stand alone appendices. Appendix A, A Summary of Leaks and Spills Contributing to 241-AX Tank Farm Vadose Zone Contamination, provides information relative to Item 2 above. Appendices B through E, Best-Basis Inventory, Retrieval Tnventory and Teakage Tnventory Estimates of Waste from Single-Shell Tanks 241-AX-101. through 241-AX-104 provide the information described in Items 1, 3, and 4 above. Appendix $r$, Report of Best-Estimate Past Release Vadose Zone Contamination of the 241-AX Tank Farm provides additional data for information relating to Item 2 . This report supplements and complements the vadose zone characterization information provided by U.S. Department of Energy - Richland Operations Office (DOE-RL) (1997).

\subsection{REFERENCES}

DOE-RL, 1997, AX-Tank Farm Preliminary Report, GJO-HAN-10, April 1997, U.S. Department of Energy, Richland Operations Office, Richland, Washington. 
HNF-SD-HTI-TI-001, REV. 0

SESC-EN-RPT-002, Rev. 1

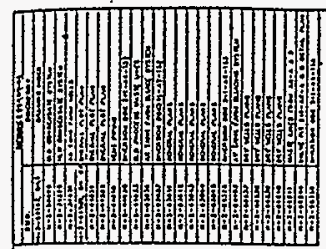

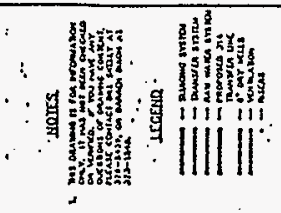

Figure 1. AX Tank Farm Borehole Arrangement

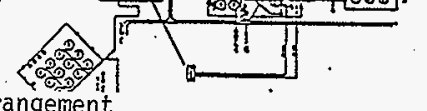

(formalty known as)

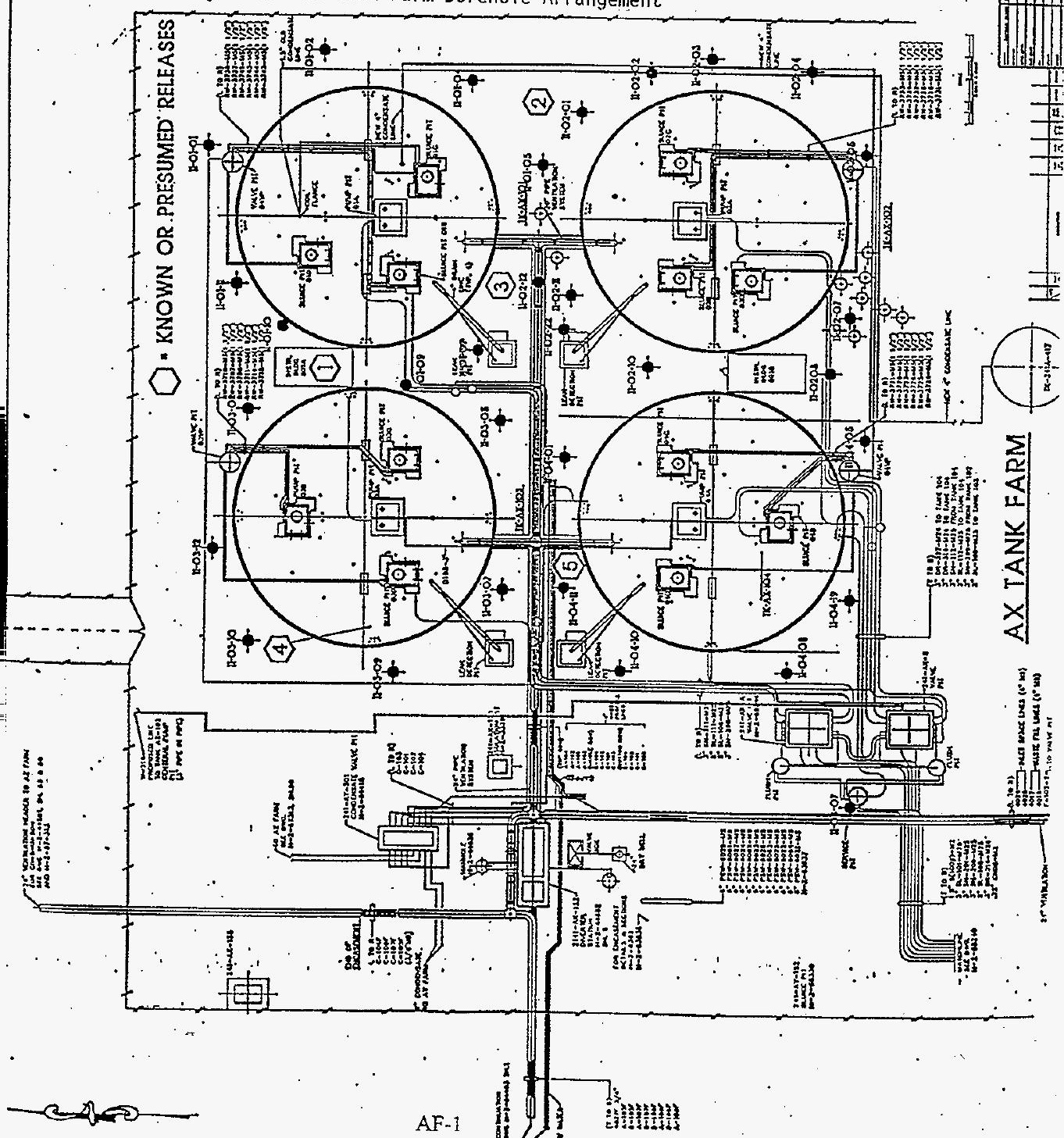




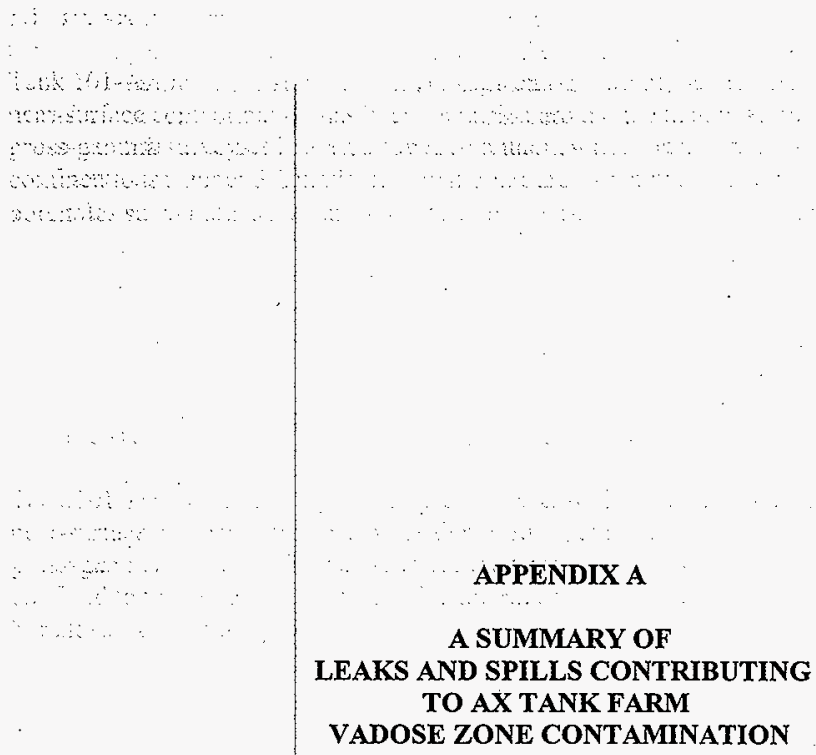

T. W. Staehr

SGN Eurisys Services Corporation

Richland, Washington 
1.0 PAST PRACTICE LEAKS AND SPILIS IN THE 241-AX TANK FARM $\ldots \ldots \ldots$ A-1

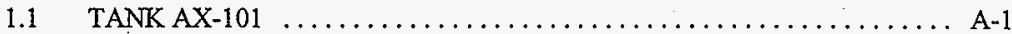

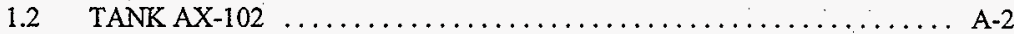

1.3 TANK AX-103 $\ldots \ldots \ldots \ldots \ldots \ldots \ldots \ldots \ldots \ldots \ldots \ldots \ldots \ldots \ldots \ldots, \ldots \ldots \ldots$

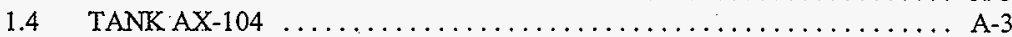

2.0 PAST PRACTICE LEAKS AND SPILLS OUTSIDE THE 241-AX TANK FARM . A-4

2.1 216-A-40 TRENCH $\ldots \ldots \ldots \ldots \ldots \ldots \ldots \ldots \ldots \ldots \ldots \ldots \ldots \ldots \ldots$ A-4

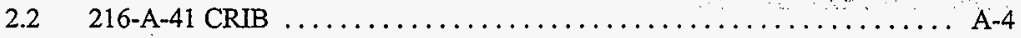

2.3 RAW WATER LINE $\ldots \ldots \ldots \ldots \ldots \ldots \ldots \ldots \ldots \ldots \ldots \ldots \ldots \ldots \ldots \ldots \ldots \ldots$

3.0 POTENTIAL FUTURE LEAKS DURING RETRIEVAL OPERATIONS $\ldots \ldots \ldots$ A-4

3.1 EXISTING TRANSFER LINES $\ldots \ldots \ldots \ldots \ldots \ldots \ldots \ldots \ldots \ldots \ldots \ldots$ A-4

3.25 W-314 TRANSFER LINES $\ldots \ldots \ldots \ldots \ldots \ldots \ldots \ldots \ldots \ldots \ldots \ldots \ldots$ A 5

3.3 AX-A AND AX-B VALVE PITS $\ldots \ldots \ldots \ldots \ldots \ldots \ldots \ldots \ldots \ldots$ A -5

4.0 SUMMARY OF KNOWN OR PRESUMED RELEASES $\ldots \ldots \ldots \ldots \ldots \ldots \ldots$ A-5

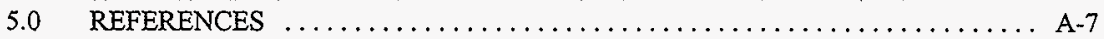

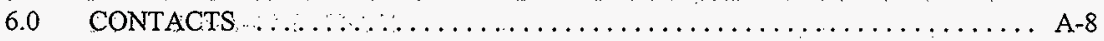

\section{FIGURES:}

1. AX Tank Farm Borehole Arrangement ............................ AF-1 
(formal1y known as)

The purpose of this study is to provide historical data to support estimates for the nature and extent of vadose zone contamination resulting from past-practice leaks and leaks during waste retrieval operations, in tanks AX-101, 102, 103, and 104. The data provided in this report are a combination of research of both published and unpublished reports, occurrence reports, letters, memos, and personnel interviews (Baumhardt 1989, Becker 1997, Deford and Carpenter 1995, Hamilton 1997, Hanlon 1995, and RHO 1979).

In general, the AX tanks were in service for approximately 17 years, from 1963 to 1980 . Tanks $\mathrm{AX}-101$ and $\mathrm{AX}-103$ have been categorized as non-leakers and tanks $\mathrm{AX}-102$ and $\mathrm{AX}-104$ are categorized as assumed leakers. The basis for categorizing the AX-102 and AX-104 tanks as assumed leakers was either through the detection of radiation in surrounding leak detection wells, or through excessive decreases in liquid level, beyond those attributed to evaporation. No evidence was found that indicates that there were any leaks due to a definite breach of any of the four AXtanks:

Monitoring boreholes were drilled around all four of the tanks between 1974 and 1978 .

Historical gross-gamma plots indicate that near-surface contamination was present in all tanks before the boreholes were drilled, thus the majority of the leaks/spills are assumed to have occurred whilie the tanks were in service prior to 1980 . Subsurface contamination may also be the result of surface contamination being carried down during the drilling operations.

Unfortunately, documentation of these incidents is difficult to find and often does not provide a detailed account of the volume and source of the leak or spill.

The most extensive source of information on vadose contamination sources is contained in recently published reports from the U.S. Department of Energy (DOE), Grand Junction Office (JCO), (DOE-JCO 1997a, 1997b, 1997c, 1997d). The JCO has recently completed a Spectral Gamma:Logging (SGL) study of the boreholes surrounding each of the AX farm tanks, to characterize and establish a baseline of man-made radionuclide concentrations in the vadose zone, The reports provide comprehensive studies of the SGL performed on individual boreholes for each tank; as well as a summary and explanation of possible sources of contamination.

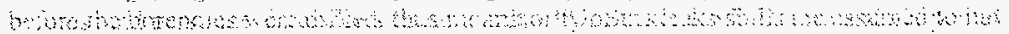
This report summarizes the results and conclusions drawn from the JCO reports concerning 241AX:Tank Farm contamination, and other sources. A summary of the known or presumed releases are contained in Section 5:0 of this Appendix:

\subsection{PAST PRACTICE LEAKS AND SPILLS IN THE 241-AX TANK FARM}

\subsection{TANK AX-101}

Tank 101 AX has no history of tank leakage and is currently considered a sound tank: However, near-surface contamination has been.identified around the tank base on the SGL and historical gross-gamma surveys. : The near-surface contamination consists mainly of ${ }^{137} \mathrm{Cs}$, and is generally confined to the upper $3: 1 \mathrm{~m} .(10 \mathrm{ft})$. Historical gross-gamma plots for the majority of the boreholes surrounding the tank show that the near-surface contamination was present before the 
boreholes were drilled and that the contamination has not migrated more than $1.5 \mathrm{~m}(5 \mathrm{ft})$ in the past 10 to 20 years.

A contributing cause of the surface contamination was a spill in the AX-801-A instrument building, located between the AX-101 and AX-102 tanks, that occurred in 1966 (Lacey 1994). The spill occurred when highly radioactive waste liquid pressurized a 103-AX tank recirculator line and flowed onto the floor of the instrument building. Dose rates from the spill were greater than $5 \mathrm{R} / \mathrm{hr}$ at a distance of $3.1 \mathrm{~m}(10 \mathrm{ft})$ from the spill. It was estimated that approximately $20 \mathrm{~L}$ (5.3 gal) of waste, containing $50 \mathrm{Ci}$ Beta, and $25 \mathrm{Ci}^{137} \mathrm{Cs}$, were spilled. The waste was washed from the instrument building, using a firehose, into a $0.9 \mathrm{~m}(3 \mathrm{ft})$ deep trench extending northward for approximately $15.2 \mathrm{~m}$ to $24.4 \mathrm{~m}(50 \mathrm{ft}$ to $80 \mathrm{ft}$ ) and then eastward for approximately $27.4 \mathrm{~m}$ (90 ft). (See note on Drawing H-2-44675). A second trench that paralleled the first trench (See drawing H-2-33295) was dug to receive a second washing. The trenches were later covered with soil. The shallow:zone of highly concentrated ${ }^{137} \mathrm{Cs}$ contamination detected by the SGL in borehole 11-01-10 may be associated with this incident.

Another oceurrence of ground contamination was reported in October 1975 (Lacey 1994) in an approximate $3: 1 \mathrm{~m}$ by $3.7 \mathrm{~m}(10 \mathrm{ft}$ by $12 \mathrm{ft})$ area between the $\mathrm{AX}-101$ and $\mathrm{AX}-102$ tanks and around monitoring borehole 11-02-01. An attempt was made to remove the contamination from around the casing.! The soil along the casing was contaminated to $90 \mathrm{mrad} / \mathrm{hr}$ at a depth of $22.9 \mathrm{~cm}$ ( $9 \mathrm{in}$ ). The source and concentration of contaminants is unknown.

Two occursence reports were issued in 1977 and another in 1980 for liquid level decreases exceeding the action criteria. However, there is no evidence indicating that these decreases were due to tank leaks.

Operating Limit Deviation Report No. 80-7 was issued in February 1980 for a liquid level decrease immediately after receiving a transfer from the 417 condensate receiver tank. The decrease was attributed to the mixing of dissimilar materials.

\subsection{TANK AX-102}

Tank AX-102 was designated as an assumed leaker in 1988 based on excessive liquid level decreases that could not be attributed to evaporation. Two occurrence reports were written in April 1975, detailing increased radiation readings in monitoring well 11-02-11 at a depth of $16: 8 \mathrm{~m}(55 \mathrm{ft})$. Many investigations, including the drilling of borehole 11-02-12, were performed between 1975 and 1988 to determine the source of the contamination (WHC 1988 and WHC 1989). However, no evidence was found indicating a tank breach. The most probable source of contamination was attributed to leakage from the tank's $50.8 \mathrm{~cm}$. (20 in.) direct buried vapor line at the point of juncture with the $61.0 \mathrm{~cm}(24 \mathrm{in}$.) vessel vent system header. The leak is presumed to have occurred at a Dresser coupling joining the $50.8 \mathrm{~cm}$ (20 in.) header from Tank AX-102 to a main 24-inch vapor header. In late 1975, an asphalt sealant was injected into the soil to contain the activity and seal the Dresser coupling leak. Activity at the $17.1 \mathrm{~m}$ ( $56 \mathrm{ft}$ ) level continued to increase until March 1976 and has since slowly diminished. Activity at the $3.7 \mathrm{~m}$ (12 ft) level in borehole 11-02-12 has remained stable, with activity below this point slowly receding. 


\subsection{TANK AX-103}

There have been no reportable occurrences of exceeding the liquid level decrease criteria or any contamination increases that would designate Tank AX-103 as an assumed leaker. SGL has indicated (DOE-JCO 1994c) that there is surface contamination in the upper sections of all seven monitoring boreholes surrounding the tank.

The SGL also indicates subsurface contamination at the $10.1 \mathrm{~m}$ to $11.3 \mathrm{~m}(33 \mathrm{ft}$ to $37 \mathrm{ft})$ level of the northwest side of the tank at monitoring boreholes 11-03-02 and 11-03-12. However, there is no evidence of a source for the contamination. Historical gross-gamma logs indicate that the contamination was present at the time the monitoring boreholes were drilled. Subsequent logs indicate that the gamma-ray activity has not migrated measurably downward into the vadose zone over time.

(3) 3 as

A possible source of this near-surface contamination was a transfer line leak, reported in 1968, that occurred while trying to unplug a transfer line from the AX-102 tank : Radiation levels on: the ground at the leak were $400 \mathrm{mrad} / \mathrm{hr}$ and gieater than $5 \mathrm{R} / \mathrm{hr}$ on the line. Some contaminated soll was removed for burial:

\section{4: TANK $A X-104$}

Tank AX-104 was designated as an assumed leaker in 1977: based on increasing radiation detected in monitoring boreholes. Increasing radiation at the $12.2 \mathrm{~m}$. $40 \mathrm{ft})$ depth of borehole 11-04 1, 1, located northwest of the AX-104 tank; was observed in early 1975 (ARCHO 1975). However; neither tank liquid level, leak detection pit liquid level, or radiation monitoring gave any indication of tank leakage. Through subsequent investigation, the source of the contamination was presumed to be from leaks at Dresser.coupling joints on the tanks $50.8 \mathrm{~cm}$ ( 20 in) vapor line at points where the line ties into the tank and where the line ties into the: $61: 0 \mathrm{~cm}$ (24in) yessel vent header.

Whasurat:

Increasing radiation was also detected in boreholes 11-04-01 and 11-04-11 in February 1976. The gamma profiles supported the assumption that leaks were from Dresser coupling connections at the $A X-104$ tanks and at the $61.0 \mathrm{~cm}$ (24 in:) vapor header. Historical gross-gamma profiles for Tank AX-104 identified contamination at borehole 11-04-11 at far lower depths than similar: Dresser coupling leaks for Tank AX-102: A possible explanation is that there was a tank breach, or that the leak at the juncture of the $50.8 \mathrm{~cm}$ (20 in.) vapor header and the AX-104 tank migrated down the outside of the tank.

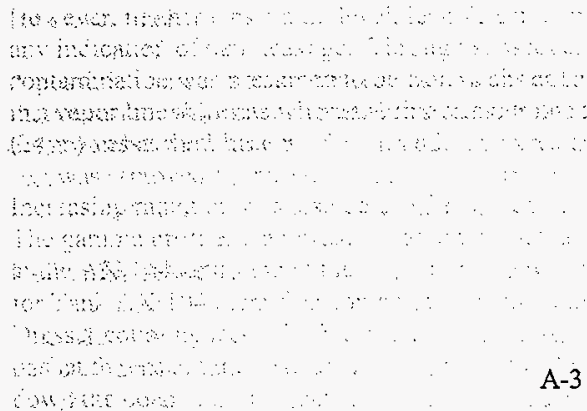




\subsection{PAST PRACTICE LEAKS AND SPILLS OUTSIDE THE 241-AX TANK FARM}

\subsection{6-A-40 TRENCH}

The $21.6-\mathrm{A}-40$ trench is reported to have received $9.5 \times 10^{5} \mathrm{~L}\left(2.5 \times 10^{5} \mathrm{gal}\right)$ of diverted cooling water and steam condensate from the 244AR vault, (WHC 1990). The open trench is $121.9 \mathrm{~m}$ $(400 \mathrm{ft})$ long by $6.1 \mathrm{~m}(20 \mathrm{ft})$ wide, and is located approximately $152.4 \mathrm{~m}(500 \mathrm{ft})$ west of the 241-241-AX Tank Farm. The trench has been described as "a rubber bag type diverter trench for the recovery of radioactive cooling water that might become contaminated from equipment failure."

\section{2\%216-A 41 CRIB}

The 216-A-41 crib was in service from 1968 to 1974 and received drainage from the 244AR yault canyon and icell exhauster stack (296-A-13) (WHC 1990). The gravel-filled crib has a $3.1 \mathrm{~m}$ by $3.1 \mathrm{~m}$ ( $10 \mathrm{ft}$ by $10 \mathrm{ft}$ ) bottom surface and is located approximately $152.4 \mathrm{~m}(500 \mathrm{ft})$ west and $61 \mathrm{~m}(200 \mathrm{ft})$ south of the 241-AX Tank Farms.

\subsection{RAW WATER LINE}

On February 3, 1993, raw water was valved in to the 241-AX Tank Farm to support a flushing operation of the 241 AX-B valve pit, (WHC 1993). The flushing operation was completed at approximately 1200 hours and all but one valve was returned to the original configuration. At approximately 2200 hours, the Computer Automated Surveillance system (CASS) operator informed the operations shift supervisor that a raw water meter was measuring water usage in 241- $\mathrm{AX}, \mathrm{AY}$, or $\mathrm{AZ}$ farms. The leak was determined to be located to the south of the AX-B Valve Pit, southwest of the 241-AX Tank Farms. Approximately 13,250 L (3,500 gal) of raw water was estimated to have been discharged to the soil.

a.s.

\section{A 3,0 POTENTIAL FUTURE LEAKS DURING RETRIEVAL OPERATIONS}

\subsection{EXISTING TRANSFER LINES}

There are currently two existing transfers lines in the vicinity of the 241-AX Tank Farm that are a:source for potential leaks. These lines have been in service for more than 20 years and will be used to provide waste feed from the $\mathrm{AZ}$ and $\mathrm{AN}$ tank farms to the privatized vitrification facilities: The lines are both $5.1 \mathrm{~cm}(2 \mathrm{in}$.) diameter schedule 80 pipe that are encapsulated (pipe-in-pipe) with 10:2 $\mathrm{cm}$ (4 in.) schedule 40 pipe. The lines run in a north-south direction between the AX-A valve pit to the 241-AZ Tank Farm, (drawings H-2-70763, and H-2-70765). The closest point that the lines gets to the 241-AX Tank Farm is at a $8.5 \mathrm{~m}(28 \mathrm{ft}$ ) long expansion loop run located due west of Tank AX-104 and approximately $33.5 \mathrm{~m}$ (110 ft) from the tank centerlinet The lines make a right angle to the west for $2.1 \mathrm{~m}(7 \mathrm{ft})$ before turning north again for 
(formally known as)

approximately $22.6 \mathrm{~m}$ (74 ft). From this point, the lines again make a right angle to the west for $3.4 \mathrm{~m}(11.25) \mathrm{ft}$ before turning north for $25.3 \mathrm{~m}(83 \mathrm{ft})$.

\subsection{W-314 TRANSFER LINES}

The W-314 Project is planning to install a $7.6 \mathrm{~cm}(3 \mathrm{in}$.) transfer line with a $15.2 \mathrm{~cm}(6 \mathrm{in}$.) secondary containment that would be located east of and running parallel to the existing transfer lines. The proposed line would tie into the west side of the 241-AX-B pit and run north to the 241-AZ-A pump pit located on the AZ-102 tank. The line would also be used to provide waste feed to the vitrification facilities.

\section{3:3 AX-A AND AX-B YALVE PITS}

The AX-A and AX-B valve pits are located just southwest of the 241-AX Tank Farm. The valve pits serve as a junction for transfer lines through the use of piping jumpers connected to the bridge transfer line: The replacement of piping jumpers has been a source of surface contamination in the past. Transfers from the AN, AZ, and $\mathrm{AY}$ farms to the vitrification facilities will be routed through the $\mathrm{AX}-\mathrm{A}$ and $\mathrm{AX}-\mathrm{B}$ valve pits.

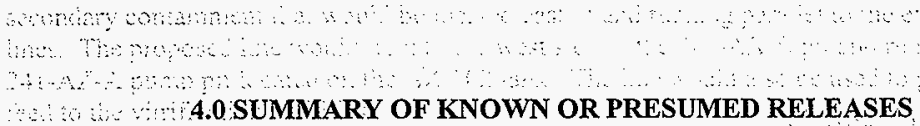

\section{TANLWAX-101}

TODATE:

O.: $:$ VOLUME:

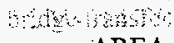

CAREA:

QTMFW:

CONCENTRATION: REFERENCE:
June 1966

$20 \mathrm{~L}(5.3 \mathrm{gal})$ of tank waste diluted with several hundred gallons (estimated) of wash water.

Surface spill from the north end of the 801-A instrument building into two parallel $0.9 \mathrm{~m}(3 \mathrm{ft})$ deep trenches running north $15.2 \mathrm{~m}$ to $24.4 \mathrm{~m}$ ( $50 \mathrm{ft}$ to $80 \mathrm{ft}$ ) and then east for approximately $27.4 \mathrm{~m}(90 \mathrm{ft})$. $50 \mathrm{Ci}$ Beta, $25 \mathrm{Ci}^{137} \mathrm{Cs}$ See 241-AX Tank Farm Figure 1, 241-AX Tank Farm Borehole Arrangement Plan View

October 1975

Unknown

Surface spill in an area approximately $3.1 \mathrm{~m}$ by $3.7 \mathrm{~m}(10 \mathrm{ft}$ by $12 \mathrm{ft}$ ) between $\mathrm{AX}-101$ and $\mathrm{AX}-102$ and around monitoring well 11-02-01.

$90 \mathrm{mrad} / \mathrm{hr}$ at $22.9 \mathrm{~cm}$ ( 9 in.) deep

See 241-AX Tank Farm Figure 1, 241-AX Tank:Farm Borehole Arrangement Plan View 
3. DATE:

VOLUME:

AREA:

CONCENTRATION:

REFERENCE:
May 1975

$11,356 \mathrm{~L}(3,000 \mathrm{gal})$

Presumed to originate from $50.8 \mathrm{~cm}(20 \mathrm{in}$.) vapor header at juncture with $61.0 \mathrm{~cm}(24 \mathrm{in}$.) header

Auger soil sample read $3 \mathrm{Rad}$ at contact

See 241-AX Tank Farm Figure 1, 241-AX Tank Farm

Borehole Arrangement Plan View

\section{TANKAX-103}

4. DATE:

A. VOLUME:

AREA:

CONCENTRATION:

REFERENCE:

STA

TANKAX-104

5. DATE:

VOLUME:

AREA:

CONCENTRATION:

REFERENCE:

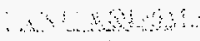

\section{AX EARM VICINITY}

6. DATE:

VOLUME:

1. AREA:

CONCENTRATION:

REFERENCE:

7. DATE:

VOLUME:

AREA:

CONCENTRATION:

REFERENCE:

\section{January 1968}

Unknown, soil removed for disposal

Transfer line at tank AX-103

$400 \mathrm{mrad} / \mathrm{hr}$ at the surface; $5 \mathrm{R} / \mathrm{hr}$ at the pipe surface

See 241-AX Tank Farm Figure 1, 241-AX Tank Farm

Borehole Arrangement Plan View:

April 1975

$30,283 \mathrm{~L}(8,000 \mathrm{gal})$

Borehole 11-04-11 at $12.2 \mathrm{~m}(40 \mathrm{ft})$ depth

Auger soil sample read $3 \mathrm{Rad}$ at contact

See 241-AX Tank Farm Figure 1, 241-AX Tank Farm

Borehole Arrangement Plan View .

$1968-1975$

$9.5 \times 10^{5} \mathrm{~L}\left(2.5 \times 10^{5} \mathrm{gal}\right)$

216-A-40 Trench - $121.9 \mathrm{~m}(400 \mathrm{ft})$ long by $6.1 \mathrm{~m} \mathrm{(20 \textrm {ft } )}$ wide, located approximately $152.4 \mathrm{~m}(500 \mathrm{ft})$ west of the 241-AX Tank Farm

Radionuclide content unknown

See 241-AX Tank Farm Figure 1, 241-AX Tank Farm

Borehole Arrangement Plan View

$1968-1974$

Unknown

216-A-41 Crib - 3.1-m (10-ft) by 3.1-m (10-ft) bottom surface, located approximately $152.4 \mathrm{~m}(500 \mathrm{ft})$ west and $61 \mathrm{~m}(200 \mathrm{ft})$ south of the 241-AX Tank Farm.

Small amounts of Beta, potentially slightly acidic See 241-AX Tank Farm Figure 1, 241-AX Tank Farm Borehole Arrangement Plan View 


\subsection{REFERENCES}

(formally known as)

ARCHO 1975, Increasing Dry Well Radiation Adjacent to Tank 104-AX, ARCHO Occurrence Report, April 9, 1975, Report No. 75-47.

Baumhardt, R. J., 1989, Letter to R.E. Gerton, Single Shell Tank Leak Volumes, dated May 17, 1989, Westinghouse Hanford Company, Richland, Washington

Becker, D.L., 1989, Letter to L. A. Fort, Engineering Data Requirements for Developing Retrieval Performance Evaluation Criteria, dated February 13, 1997, Numatec Hanford Corporation, Richland, Washington

Deford, D.H., and Carpenter, R.W., 1995, PUREX Plant Aggregate Area Management Study Technical Baseline Report, BHI-00178, May 1995, Bechtel Hanford, Inc., Richland, Washington.

DOE-JCO 1997a, Tank Sümmary Report for Tank AX-101, GJ-HAN-49, January 1997, U. S. Department of Energy-Grand Junction Office, Grand Junction, Colorado.

DOE-JCQ1997b, Tank Summary Repont for Tank AX-102, GJ-HAN-50, January 1997, U. S. Department of Energy-Grand Junction Office, Grand Junction, Colorado.

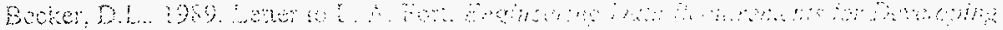

DOE-JCO 1997c, Tank Summary Report for Tank AX-103, GJ-HAN-51, Märch 1997, U. S. Department of Energy-Grand:Junction Office, Grand Junction, Colorado.

DOE-JCO 1997d, Tank Summary Report for Tank AX-104, GJ-HAN-52, January 1997, U. S. Department of Energy-Grand Junction Office, Grand Junction, Colorado. Bash,

Hamilton; D. H. 1997, Letter to R. W. Root, Hanford Tank Initiative - AX Tank Farm Source Dif. Term, Retrieval Performanice Evaluation Criteria, dated March 14, 1997, SGN Eurisys Services Corporation, Richland, Washington.

Hanlon, B M, 1995, Waste Tank Stummary Report for Month Ending May 31, 1995,

WHC-EP-0182-86, July 1995, Westinghouse Hanford Company, Richland, Washington.

Lacey, W:K 1994, East Tank Farms: Occurrence Reports.

RHO 1979, Handbook 200 Area Waste Sites, RHO-CD-673; Volume 1, Rockwell Hanford O), Operations, Richland, Washington.

WHC 1988, Tank:AX-102 Exceeding 1" Waste Level Decrease, WHC Unusual Occurrence Report, dated December 7, 1988; WHC-UO-88-029-TF-04, Westinghouse Hanford Company, Richland, Washington.

WHC 1989, Surface Level Measurement Decrease in SST AX-102, WHC Unusual Occurrence Awion Report, dated May 18, 1989; WHC-UO-89-023-TF-05, Westinghouse Hanford Company, Richland, Wáshingtón. 
WHC 1990, A History of the 200 Area Tank Farms, WHC-MR-0132, Westinghouse Hanford Company, Richland, Washington.

WHC 1993, 3500 Gallons of Raw Water Flow in Tank Farm 241-AX Indicates Line Failure, WHC Occurrence Report, dated February 6, 1993, RL--WHC-TANKFARM-1993-0021, Westinghouse Hanford Company, Richland, Washington.

\title{
6.0 CONTACTS
}

\author{
Barnes, Dave Environmental Engineering Support \\ Culmer, Jack Environmental Integration \\ 373-4942 2440STVCN/2616 \\ Farrell, Kelsey East Tank Farms Occurrence Reporting \\ W.7.:.: 373/91:81 : : 272AW/B111 \\ Lacey, Wendy - Environmental Health and Safety \\ 373-2973 MO281/A109/200W \\ Miller, Phil Environmental Cleanup and Compliance \\ 3. $373-6389 ; 2750 \mathrm{E} / \mathrm{A} 109$. \\ Reberger, Dan East Tank Farms Transfer Cog. Eng. \\ 373-3926 . MO268/1; \\ Scott-Proctor, Nancy East Tank Farms Operations Support \\ 1... 373-1945 272AW/B106
}




\section{APPENDIX B \\ BEST-BASIS INVENTORY, RETRIEVAL INVENTORY, AND LEAKAGE INVENTORY ESTIMATES FOR RETRIEVAL OF WASTE FROM SINGLE-SHELL TANK 241-AX-101}

D. W. Hendrickson, P.E.

S. L. Lambert, Ph.D.

SGN Eurisys Services Corporation

Richland, Washington

B-i 
CONTENTS

1.0 CHEMICAL INFORMATION SOURCES $\ldots \ldots \ldots \ldots \ldots \ldots \ldots \ldots \ldots \ldots, \mathrm{B}-1$

2.0 CHEMICAL/RADIONUCLIDE INVENTORY ESTIMATES BEFORE

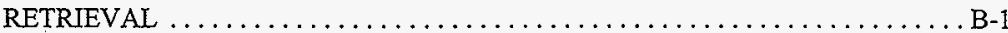

3.0 CHEMICAL/RADIONUCLIDE INVENTORY ESTIMATES AFTER

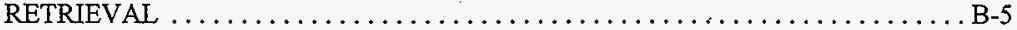

4.0 BEST-BASIS LEAKAGE INVENTORY ESTIMATES FOR RETRIEVAL OF

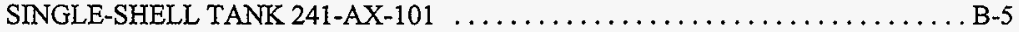

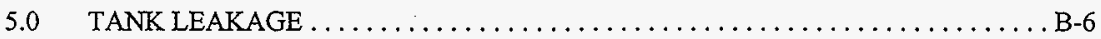

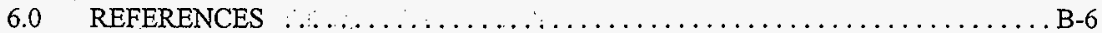

\section{TABLES:}

1. Estimated Inventory of Strontium Recovery Sludge Nonradioactive Components in Tänk 241-AX-101: Waste Sludge . ........................... BT-1

2. Estimated Inventory of Strontium Recovery Sludge Radioactive Components in Tank 241-AX-101 Waste Sludge (Decayed to January 1, 1994) ........... BT-2

3. SMMA1 Saltcake Composition and Inventory Projections for Tank 241-AX-101 Based on Core Samples from Tanks 241-A-102 and 241-A-103 and Auger Samples

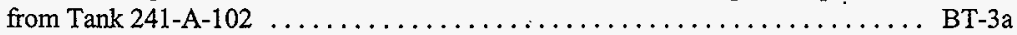

4. Analytical Results and Tank Inventory Estimates for Radioactive Components in SMMA1 Saltcake in Tank 241-AX-101 Based on Core Samples from

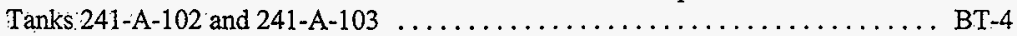

5. Comparison of Sample and Process Based and Hanford Defined Waste Inventory

Estimates for Nonradioactive Components in Tank 241-AX-101 .......... BT-5a

6. Comparison of Sample and Process Based and Hanford Defined Waste Inventory

Estimates for Radioactive Components in Tank 241-AX-101 ............ BT-6a

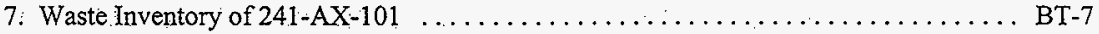

8. Waste Transaction Information for Tank $241-\mathrm{AX}-101 \ldots \ldots \ldots \ldots \ldots \ldots \ldots \ldots \ldots \ldots \ldots \ldots$

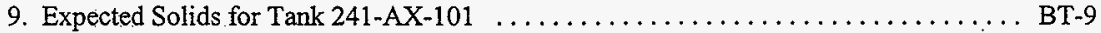

10. Hanford Defined Waste Model Solids for Tank 241-AX-101 ............... BT-10

11. Relative Volume of Layers in Tanks 241-A-102 and 241-AX-101 ............ BT-11

12. Best-Basis Inventory of Waste from Single-Shell Tank 241-AX-101 ......... BT-12a

13. Best-Basis Radionuclide Inventory Before Retrieval of Waste from Single-Shell

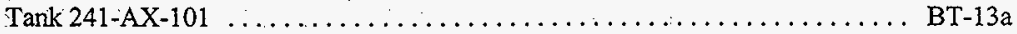

14. Retrieval Scenario Summary of Residual Waste and Fractional Removal . . . . . . . BT-14

15. Tank 241-AX-101 Nonradiological Waste Residual Inventory Following Retrieval BT-15a

16. Tank 241-AX-101 Radiological Waste Residual Inventory Following Retrieval ... BT-16a

17. Retrieval Scenario Product Solution Nonradiological Analyte Concentrations ..... BT-17a

18. Retrieval Scenario Product Solution Radiological Analyte Concentrations ........ BT-18a 


\section{CONTENTS (cont'd)}

\section{TABLES (cont'd):}

19. Tank 241-AX-101 Retrieval Scenario Nonradiological Constituent Leakage

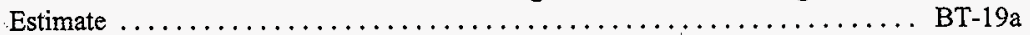

20. Tank 241-AX-101 Retrieval Scenario Nonradiological Constituent Leakage

Estimate 
The purpose of this study is to provide the best-basis estimate of the chemical and radiological waste inventory after retrieval of waste from the $\mathrm{AX}$ farm. As part of this effort, an evaluation of available information for Tank $241-\mathrm{AX}-101$ was performed and a best-basis inventory was established for three different retrieval scenarios. The first scenario is based on retrieving at least 90 percent of the waste to a residual volume of $101.94 \mathrm{~m}^{3}\left(3,600 \mathrm{ft}^{3}\right)$ of waste, or the current volume if this volume is less than $101.94 \mathrm{~m}^{3}\left(3,600 \mathrm{ft}^{3}\right)$ The second scenario assumes 99 percent retrieval of waste from the tank to meet the Hanford Federal Facility Agreement and Consent Order (Tri-Party Agreement) (Ecology et al. 1990) milestone of $10: 2 \mathrm{~m}^{3}\left(360 \mathrm{ft}^{3}\right)$ of residual waste, while the third scenario assumes 99.9 percent retrieval to a residual volume of $1.02 \mathrm{~m}^{3}$ $\left(36 \mathrm{ft}^{3}\right.$ ) of waste. This study, detailed in the following sections, is based on the methodology that was established by the standard inventory task.

\subsection{CHEMICAL INFORMATION SOURCES}

Chemical and radionuclide inventory estimates are generally derived from one of three sources of information: (1) sample analysis and sample derived inventory estimates, (2) component inventories predicted by the Hanford Defined Waste (HDW) model based on process knowledge and historical tank transfer information, or (3) a a tank-specific process estimate based on process flowsheets, reactor fuel data, essential materials records, or comparable sludge layers and sample information from other tanks.

Tank 241-AX-101 was placed into service in 1965. Initial tank receipts included Plutonium-Uranium Extraction (PUREX) process high-level waste (HLW), organic wash waste and B Plant fission product waste. Typically, these wastes were received from other tanks rather than directly from the plants: Steam coils were added to the tank in 1966 and the tank was used to concentrate the PUREX HLW, organic wash waste, and B Plant fission product additions.

During 1968 and 1969, the tank was used to accumulate $\mathrm{Sr}$ and Cs recovery waste for staging to Tank:241-A-102. The tank received little transfer activity until the end of 1973 when most of the supernatant was removed PUREX:HLW supernatant was sent to the tank in 19.73 and 1974. Pumping and sluicing of the tank contents for Sr and Cs recovery in 1975 and 1976 reduced the tank solids inventory to $11.35 \mathrm{kC}$ of strontium recovery (SRR) sludge (Rodenhizer 1987).

After sluicing, Tank-241-AX-101 was used to receive product slurry from the 242-A Evaporator (1976-1980) Several evaporator products were added to Tank 241-AX-101, including

Evaporator Bottoms; Hanford Defense Residual:Liquid, and Double-Shell Slurry Feed. The tank also received complex waste.

\subsection{CHEMICAL/RADIONUCLIDE INVENTORY ESTIMATES BEFORE RETRIEVAL}

No current analyses of SRR are available; however, application of the HDW SRR sludge compositions to the small SRR volume ratioed to the volume of sludge deposited. in Tank 
(formally known as)

241-AX-101 may provide a reasonable assessment of the sludge compositions. The summary of nonradioactive and radioactive constituents of this sludge analysis are contained in Tables 1 and 2 , respectively. The chemical species are reported without charge designation per the best-basis inventory convention.

SMMA1 saltcake analyses have been conducted upon samples withdrawn from both Tanks 241-A-102 and 241-A-103. As was represented in the standard inventory assessment for Tank 241-AX-103.(Lambert and Hendrickson 1997), these saltcakes, with adjustment for iron, silica, and nickel, are expected to yield a reasonable estimate of the composition and inventory of Supernatant Mixing Model 242-S Evaporator saltcake generated from 1973 until 1976. (SMMA.1) saltcake within Tank 241-AX-101. The summary of nonradioactive and radioactive constituents for this saltcake analysis are contained in Tables 3 and 4, respectively.

\subsection{COMPONENT INYENTORY EVALUATION}

i. nom som wion.

The following evaluation of tank contents is performed to identify potential errors and/or missing information that would influence the sampling-based and HDW model component inventories.

The HDW model is based primarily on process production waste compositions, waste transaction records for each tank, and assumed solubilities for key components. The sample and process based estimate is based upon HDW-based SRR sludge compositions and SMMA1 saltcake samples from Tanks 241-A-102 and 241-A-103. The sample and process based estimate does not encompass PUREX neutralized high-level (P2) waste of which $38 \mathrm{~kL}(10 \mathrm{kgal})$ is described as being present by the Waste. Status and Transaction Record Summary (WSTRS) model (Agnew et:al. 1997b). Because that model describes its placement into the tank, following sluicing in 1975 to 1976 as P2 waste was produced from 1963 to 1967 , it is not credible that direct placement of this waste type occurred in this tank. The volume ascribed to P2 waste is assumed to be SMMA1 saltcake from the subsequent operations yielding approximately 99.6 percent saltcake by volume in the tank.

Table 5 tabulates a comparison between the HDW model compositions for nonradioactive components with that estimated from sample data and limited (SRR sludge) HDW model input.

\subsection{CONTRIBUTING WASTE TYPES}

The current waste volumes for Tank 241-AX-101 are shown in Table 7 (Hanlon 1996).

Table 8 summarizes the documented quantities of waste discharged to Tank 241-AX-101 from the HDW model waste transaction database (Agnew et al. 1997b). Table entries with negative : values are for transfers out of the tank: Quantities removed by self-concentration have not been included These records indicate that the solids in this tank should be mostly salts from concentration of dilute wastes.

The types of solids that have accumulated in Tank 241-AX-101 are compiled in Tables 9 and 10. Waste types in brackets are expected to have been removed when the tank was sluiced in 1976. 


\subsection{EVALUATION OF SAMPLE AND PROCESS FLOWSHEET INFORMATION}

Waste samples from Tank 241-AX-101 are limited to sludge samples collected before the tank was sluiced in 1976 and a supernatant sample collected in 1980. These samples are of limited value in establishing the current inventory in this tank.

Review of Anderson (1990) and Agnew et al. (1997a) indicates that the following events have probably occurred:

- Between startup in 1965 and sluicing in 1976, Tank 241-AX-101 was used to store various wastes generated by PUREX and Waste Fractionization.

- In 1976, Tank 241-AX-101 was sluiced to a $11.35 \mathrm{~kL}$ heel. This met the sludge heel requirement for tanks scheduled to be used for saltcake storage of a $2.5-\mathrm{cm}$ to $5-\mathrm{cm}$ (1-in. to 2 -in.) sludge heel. The requirement was based on radiolytic heating temperature control limits (Rodenhizer 1987).

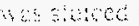

- $23373 \mathrm{~kL}$ (673 kgal) of solids were accumulated in the tank by the end of 1977 . The solids are identified as EVAP, RESID, and DSSF. These are all evaporator concentrates Se made from tank waste supernatants.

manty owert

- $\quad$ At the end of 1979, supernatant from Tank 241-AX-101 was sent to the 242-A Evaporator.: Evaporator product, potentially from a different source, was returned to the tank

- In 1980, the tank was used to stage supernatant and first pass slurry to the 242-A Evaporator: The solids level was measured at $1,094 \mathrm{~kL}$ (289 kgal).

- At the end of 1980 , the tank was filled with DSSF, bringing the solids level to $1,987 \mathrm{~kL}$ $(525 \mathrm{kgal})$ :

- Cooling of the waste caused additional salt precipitation, bringing the solids level to $2 ; 831 \mathrm{~kL} ;(748 \mathrm{kgal})$.

From these observations, it appears that the waste layers identified in the HDW model generally represent the current solids inventory in this tank:

Of the alternatives available for establishing the composition of the waste in Tank 241-AX-101, the only practical method is to use sample data for the same waste from another tank. The SORWT Model groups; Tanks 241-A-101, 241-A-102, 241-A-103, and 241-AX-101 as similar tanks. Both Tanks 241-A-102 and 241-A-103 have been sampled. However, the history of Tank 241-A-102 is somewhat unique. Tank 241-A-102 was the 242-A. Evaporator feed tank rather than a saltcake receiver tank during the time period that 241-AX-101. was filled.

A tank-by-tank review of the HDW. model was completed to identify other tanks with the waste layers found in.Tank 241-AX-101. Tanks 241-A-106 and 241-C-104 were found to contain some of the waste layers found in Tank 241-AX-101. However, Tank 241-A-106 has not been sampledand the layers in Tank $241 . \mathrm{C}-106$ are too thin to discriminate from each other: 
(formal1y known as)

Relative to the expected waste types in Tank 241-AX-101, Tank 241-A-102 has less contribution from the SMMA1 layer and more contribution from the other layers. The relative contribution of the layers for these two tanks is compared in Table D3-6. Use of the Tank 241-A-102 data is also biased by this tank being the evaporator feed tank. In this capacity, it would tend to preferentially accumulate those saits that first precipitate, e.g., $\mathrm{NaNO}_{3}$. Thus, the use of samples from both Tank 241-A-102 and Tank 241-A-103 is expected to better represent the saltcake present in 241-AX-101 than from 241-A-102 alone.

Table 11 compares the relative waste layers in Tanks 241-A-102 and 241-AX-101. This comparison shows that 91 percent of the waste in Tank 241-A-102 consists of SMMA1 and SMMA2 saltcakes from the 242-A evaporator, while 98 percent of the waste in Tank 241-AX-101 was derived from this source. Because Tank 241-A-102 was used as the evaporator feed tank, 241-A-102 waste could be enriched in those salts that first precipitate, e.g., $\mathrm{NaNO}_{3}$.

Based on the projected types of waste of each tank, samples from Tank 241-A-102 appear to be generally representative of the SMMA1 saltcake wastes in Tank 241-AX-101.

Currently, the only practical method for estimating the composition in this tank is to use sample data for similar wastes in another tank. The SORWT Model generally identifies tanks with similar wastes. According to this model, Tanks 241-A-101, 241-A-102, 241-A-103, and 241-AX-101 have been placed into the same group of tanks with common wastes. While the sample population is limited, sample records do show that two core samples were obtained from Tank 241-A-102 in 1986 and two auger samples in 1996. Even though these wastes were derived from a common source, some differences could exist because Tank 241-A-102 was used as the 242-A evaporator feed tank when Tank 241-AX-101 was being filled with DSSF waste:

Table 12 provides the estimated composition profile for Tank 241-AX-101 waste based on the core sample and auger data from Tank 241-A-102 (Jo 1996). The waste inventory estimates are based on a waste volume of $2,831 \mathrm{~kL}\left(99,850 \mathrm{ft}^{3}\right.$ ) (Table 1) and densities of $1.59 \mathrm{~kg} / \mathrm{L}$ and 1.7 $\mathrm{kg} / \mathrm{L}$ for the core sample and auger data, respectively. This table also provides composition data from each of the sampling events as well as the composite estimate for Tank 241-AX-101 waste. While sample recoveries were relatively low for the 1996 auger samples, the 1986 cores probably represent a reliable cross-section of the Tank 241-A-102 waste. The 1986 core sample estimate represents the average of two cores taken from riser 4 . Core segment recoveries were reported to be 100 percent. Since the auger sample was taken from a different riser, the sample data was averaged to produce a composite estimate of the likely inventory in Tank 241-AX-101.

Table 13 provides a summary of the radionuclide concentrations and tank inventory estimates based on the total volume of waste in this tank $\left(2,831 \mathrm{~kL}\left[99,850 \mathrm{ft}^{3}\right]\right)$. These radionuclide inventory values were derived for $46 \mathrm{key}$ radionuclides (Kupfer et al. 1997). Often waste sample analyses have only reported ${ }^{90} \mathrm{Sr},{ }^{137} \mathrm{Cs},{ }^{239 / 240} \mathrm{Pu}$, and total uranium (or total beta and total alpha), while other key radionuclides such as ${ }^{60} \mathrm{Co},{ }^{99} \mathrm{Tc},{ }^{129} \mathrm{I},{ }^{154} \mathrm{Eu},{ }^{155} \mathrm{Eu}$, and ${ }^{241} \mathrm{Am}$, etc., have been infrequently reported. For this reason it was necessary to derive most of the 46 key radionuclides by computer models. These models estimate radionuclide activity in batches of reactor fuel, account for the split of radionuclides to various separations plant waste streams, and track their movement with tank waste transactions. (Kupfer et al. 1997 and Watrous and Wootan 1997.) Model-generated values for radionuclides in any of the 177 tanks are reported in the HDW Rev. 4 model results (Agnew et al. 1997a). (No attempt has been made to ratio or normalize model 
results for all 46 radionuclides when values for measured radionuclides disagree with the model.) For a discussion of typical error between model-derived values and sample-deriveđ values, see Kupfer et al. (1997). Radionuclide results in Table 13 have been decayed to December 31, 1999.

\subsection{CHEMICAL/RADIONUCLIDE INVENTORY ESTIMATES AFTER RETRIEVAL}

As part of this study, a best basis inventory was established for three different retrieval scenarios. The first scenario is based on retrieving waste to minimum of either the existing waste volume or a residual waste volume of $101.94 \mathrm{~m}^{3}\left(3600 \mathrm{ft}^{3}\right)$. The second scenario assumes retrieval to a residual waste volume of $10.2 \mathrm{~m}^{3}\left(360 \mathrm{ft}^{3}\right)$ which corresponds to the assumed 99 percent retrieval of waste to meet the Tri-Party Agreement (Ecology et al. 1990). The third scenario assumes retrieval to a residual waste volume of $1.02 \mathrm{~m}^{3}\left(36 \mathrm{ft}^{3}\right)$. The first and third scenarios represent the retrieval of all tank wastes to 90 percent and 99.9 percent respectively.

Table 14 contains a summary matrix of resultant saltcake and sludge volumes, and their fractional removal, following retrieval according to the three scenarios of 90 percent, 99 percent, and 99.9 percent retrieval.

Following retrieval according to the three scenarios presented in Table 14, the residual tank waste inventory has been evaluated and is presented in Tables 15 and 16 for chemical and radiological constituents, respectively.

\subsection{BEST-BASIS LEAKAGE INVENTORY ESTIMATES FOR RETRIEVAL OF SINGLE-SHELL TANK 241-AX-101}

Retrieval scenarios described in Section 3.0 provide residual inventories following fractional removal of any saltcake and sludges contained within Tank 241-AX-101. This section assumes two different leakage conditions for each retrieval scenario. The first leakage condition assumes up to $30.2 \mathrm{~m}^{3}$ ( $\left.8 \mathrm{kgal}\right)$ of potential leakage, while the second leakage condition is based on an upper bounding estimate of $151.4 \mathrm{~m}^{3}(40 \mathrm{kgal})$ of potential leakage. In each case, solution concentrations and inventories will be based on the limiting conditions for waste retrieval, either a maximum supernate concentration of five gram moles per liter sodium or a maximum value of 10 weight percent solids in the slurry, or the total volume of the retrieval solution. These limits were established to minimize the possible crystallization of sodium rich salts in the slurry transfer lines and slurry pumping problems for the slurry pumps and sluicers. The following estimates are based on the methodology that was established by the standard inventory task.

The solution concentrations resulting from dissolution and slurry with water of the tank waste to the three retrieval scenarios are provided in Tables 17 and 18 for nonradiological and radiological constituents, respectively. Table 17 also displays the limiting volume assessment required for application of sodium loading or solids loading limits and the minimum retrieval 
water to meet the limiting volume assessment based upon product specific gravities of either 1.17 or $1: 18$ for sodium limited or solids limited solutions.

Tables 19 and 20 contain the nonradiological and radiological, resultant leakage inventory estimates based upon $30.2 \mathrm{~m}^{3}(8 \mathrm{kgal})$ and $151.4 \mathrm{~m}^{3}$ (40 kgal) releases during retrieval.

\subsection{TANK LEAKAGE}

Tank 241-AX-101 is currently considered to be a sound tank with no compelling evidence of leakage. A total of eight dry wells have been drilled around the periphery of Tank 241-AX-101. Dry: wells: $11-01-04 ; 11-01-05,11-01-09$; and $11-01-10$ have produced radiation counts more than 50 counts per second above background. If, during the course of spectral gamma logging, it is determined that some leakage did occur from this tank, the chemical and radionuclide source terms could be estimated from the available supernate composition data for this tank. A supernate sample was taken from this tank in October 1980 from which the potential leakage effects could be estimated. This data will not be included in this submittal because there is no evidence at the present time that this tank has ever leaked.

\subsection{REFERENCES}

Agnew, S.:F., J. Boyer, R. Corbin, T. Duran, J. FitzPatrick, K. Jurgensen, T. Ortiz, and B.

A...... Young, 1997a, Hanford Tank Chemical and Radionuclide Inventories: HDW Model Rev.

$\therefore 4$, LA-UR-96-3860, Los Alamos National Laboratory, Los Alamos, New Mexico.

$\therefore \therefore \cdots . \therefore$

Agnew, S. F, R: A. Corbin, T. B. Duran, K. A. Jurgensen, T. P. Ortiz, and B. L. Young, 1.997b, A.....Waste, Status and Transaction Records Summary (WSTRS Rev. 4), LA-UR-97-311, Rev.

$\therefore$..... Los Alamos National Laboratory, Los Alamos, New Mexico.

Anderson, J. D., 1990, A History of the 200 Area Farms, WHC-MR-0132, Westinghouse Hanford Company, Richland, Washington.

Ecology, EPA, and DOE, 1990, Hanford Federal Facility Agreement and Consent Order, 2

$\because \therefore$ vols.; as amended, Washington State Department of Ecology, U.S. Environmental

$\therefore \because$ Protection Agency, U.S. Department of Energy, Olympia, Washington.

Hanlon, B. M., 1996, Waste Tank Summary Report for Month Ending May 31, 1996; $\therefore$ WHC-EP-182-99, Westinghouse Hanford Company, Richland, Washington.

Hill,-J. G.; G. S. Anderson, and B. C. Simpson, 1995, The Sort on Radioactive Waste Type Model: A Method to Sort Single-Shell Tanks into Characteristic Groups, PNL-9814, Rev. 2, Pacific Northwest Laboratory, Richland, Washington.

$\therefore \because$ 
Hodgson, K. M., and M. D. LeClair, 1996, Work Plan for Defining a Standard Inventory Estimate for Wastes Stored in Hanford Site Underground Tanks, WHC-SD-WM-WP-311, Rev. 1, Lockheed Martin Hanford Corporation, Richland, Washington.

Jo, J., 1996, Tank Characterization Report for Single Shell Tank 241-A-102, WHC-SD-WM-ER-597, Rev. 0, Westinghouse Hanford Company, Richland, Washington.

Kupfer, M. J., A. L. Boldt, B. A. Higley, K. M. Hodgson, L. W. Shelton, and R. A. Watrous (LMHC), S. L. Lambert, and D. E. Place (SESC), R. M. Orme (NHC), G. L. Borsheim (Borsheim Associates), N. G. Colton (PNNL), M. D. LeClair (SAIC), R. T. Winward (Meier Associates), and W. W. Schulz (W2 S Corporation), 1997, Standard Inventories of Chemicals and Radionuclides in Hanford Site Tank Wastes, HNF-SD-WM-TI-740, Rev. 0, Lockheed Martin Hanford Corporation, Richland, Washington.

Kummerer, M., 1995, Heat Removal Characteristics of Waste Storage Tanks, WHC-SD-WM-SARR-010, Westinghouse Hanford Company, Richland, Washington.

Lambert, S. L., and D. W. Hendrickson, 1997, Preliminary Tank Characterization for Single-Shell Tank 241-AX-103: Best Basis Inventory, HNF-SD-WM-ER-685, Rev. 0, SGN Eurysis Services Corporation, Richland, Washington.

Rodenhizer, D. G., 1987, Hanford Waste Tank Sluicing History, SD-WM-TI-302, Rev. 0, Westinghouse Hanford Company, Richland, Washington.

Weiss, R. L. and K. E. Schull, 1988, Data Transmittal Package for Tank 241-A-102 Waste Tank Characterization, SD-RE-TI-201, Rockwell Hanford Company, Richland, Washington.

Watrous, R. A., and D. W. Wootan, 1997, Activity of Fuel Batches Processed Through Hanford Separations Plants, 1944 Through 1989, HNF-SD-WM-TI-794, Rev. 0, Lockheed Martin Hanford Corporation, Richland, Washington. 
Table 1. Estimated Inventory of Strontium Recovery Sludge Nonradioactive Components in Tank 241-AX-101 Waste Sludge

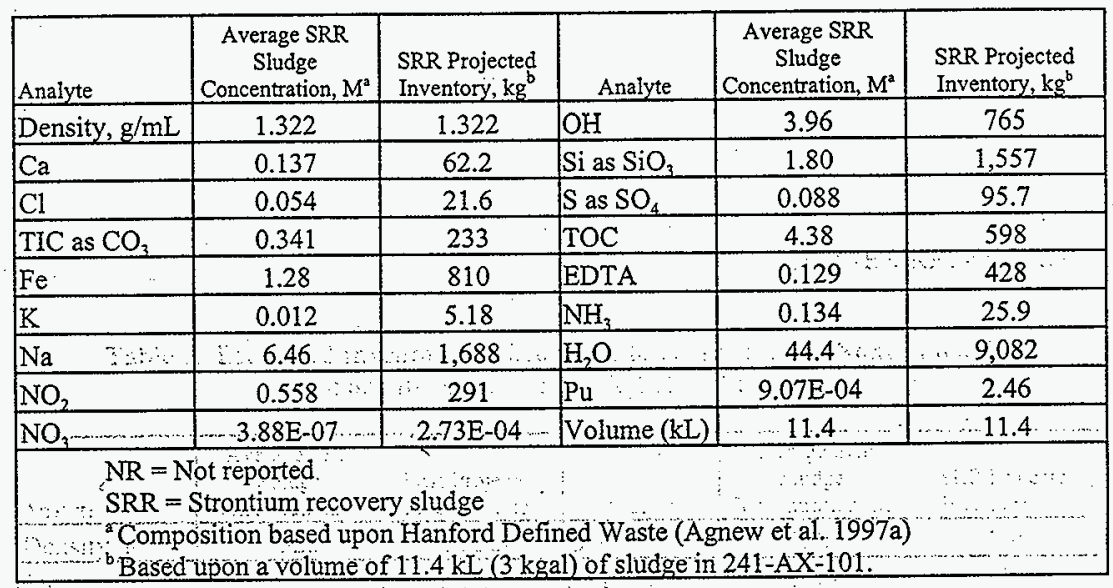


Table 2. Estimated Inventory of Strontium Recovery Sludge Radioactive Components in Tank 241-AX-101 Waste Sludge (Decayed to January 1, 1994)

\begin{tabular}{|c|c|c|c|c|c|}
\hline Analyte & $\begin{array}{l}\text { Average SRR } \\
\text { sludge } \\
\text { concentration } \\
(\mathrm{Ci} / \mathrm{L})^{2} \\
\end{array}$ & $\begin{array}{l}\text { SRR projected } \\
\text { inventory }(\mathrm{Ci})^{6}\end{array}$ & Analyte & $\begin{array}{l}\text { Average SRR } \\
\text { sludge } \\
\text { concentration } \\
(\mathrm{Ci} / \mathrm{L})^{2} \\
\end{array}$ & $\begin{array}{l}\text { SRR projected } \\
\text { inventory }(\mathrm{Ci})^{b}\end{array}$ \\
\hline${ }^{3} \mathrm{H}$ & $8.30 \mathrm{E}-05$ & 0.943 & ${ }^{227} \mathrm{AC}$ & 2.12 E-07 & 0.0024 \\
\hline${ }^{14} \mathrm{C}$ & 6.77 E-06 & 0.077 & ${ }^{228} \mathrm{Ra}$ & $1.86 \mathrm{E}-13$ & $2.11 \mathrm{E}-09$ \\
\hline${ }^{59} \mathrm{Ni}$ & $6.10 \mathrm{E}-04$ & 6.93 & ${ }^{229} \mathrm{Th}$ & $3.09 \mathrm{E}-11$ & 3.51 E- 07 \\
\hline${ }^{60} \mathrm{Co}$ & 1.37 E-05 & 0.156 & ${ }^{231} \mathrm{~Pa}$ & 3.17 E-07 & 0.0036 \\
\hline${ }^{63} \mathrm{Ni}$ & 0.060 & 681 & ${ }^{232} \mathrm{Th}$ & $2.51 \mathrm{E}-15$ & $2.85 \mathrm{E}-11$ \\
\hline${ }^{79} \mathrm{Se}$ & $3.40 \mathrm{E}-04$ & 3.86 & ${ }^{232} \mathrm{U}$ & $8.20 \mathrm{E}-12$ & $9.31 \mathrm{E}-08$ \\
\hline${ }^{90} \mathrm{Sr}$ & 9.57 & 108,717 & ${ }^{233} \mathrm{U}$ & $1.15 \mathrm{E}-13$ & $1.31 \mathrm{E}-09$ \\
\hline${ }^{90} Y$ & 9.57 & 108,717 & ${ }^{234} \mathrm{U}$ & $3.43 \mathrm{E}-08$ & $3.90 \mathrm{E}-04$ \\
\hline${ }^{93 \mathrm{~m}} \mathrm{Nb}$ & 0.0013 & 14.3 & ${ }^{235} \mathrm{U}$ & $1.34 \mathrm{E}-09$ & $1.52 \mathrm{E}-05$ \\
\hline${ }^{93} \mathrm{Zr}$ & 0.0015 & 16.7 & ${ }^{236} \mathrm{U}$ & $2.26 \mathrm{E}-09$ & $2.57 \mathrm{E}-05$ \\
\hline${ }^{99} \mathrm{Tc}$ & $4.57 \mathrm{E}-05$ & 0.519 & ${ }^{237} \mathrm{~Np}$ & $1.45 \mathrm{E}-07$ & 0.0016 \\
\hline${ }^{106} \mathrm{Ru}$ & 2.63 E-06 & 0.030 & ${ }^{238} \mathrm{Pu}$ & $4.77 \mathrm{E}-04$ & 5.42 \\
\hline${ }^{113 \mathrm{~m}} \mathrm{Cd}$ & 0.0031 & 35.5 & ${ }^{238} \mathrm{U}$ & $2.75 \mathrm{E}-08$ & $3.12 \mathrm{E}-04$ \\
\hline${ }^{125} \mathrm{Sb}$ & 8.09 E-05 & 0.19 & ${ }^{239} \mathrm{Pu}$ & 0.0128 & 145 \\
\hline${ }^{126} \mathrm{Sn}$ & $5.46 \mathrm{E}-04$ & 6.20 & ${ }^{240} \mathrm{Pu}$ & 0.00238 & 27.0 \\
\hline${ }^{129} \mathrm{I}$ & $8.89 \mathrm{E}-08$ & 0.001 & ${ }^{239 / 240} \mathrm{Pu}$ & $0: 0152$ & 171 \\
\hline${ }^{134} \mathrm{Cs}$ & 9.76 E-06 & 0.111 & ${ }^{241} \mathrm{Am}$ & 0.0144 & 164 \\
\hline${ }^{137} \mathrm{Cs}$ & 0.177 & 2,006 & ${ }^{241} \mathrm{Pu}$ & 0.0338 & 384 \\
\hline${ }^{1,37 \mathrm{~m}} \mathrm{Ba}$ & 0.167 & 1,898 & ${ }^{242} \mathrm{Cm}$ & $1.21 \mathrm{E}-05$ & 0.137 \\
\hline${ }^{151} \mathrm{Sm}$ & 1.27 & 14,439 & ${ }^{242} \mathrm{Pu}$ & 1.99 E-07 & 0.0023 \\
\hline${ }^{152} \mathrm{Eu}$ & $3.18 \mathrm{E}-04$ & 3.61 & ${ }^{243} \mathrm{Am}$ & $7.55 \mathrm{E}-07$ & 0.0086 \\
\hline${ }^{154} \mathrm{Eu}$ & 0.0075 & 84.9 & ${ }^{243} \mathrm{Cm}$ & $1.09 \mathrm{E}-06$ & 0.0124 \\
\hline${ }^{155} \mathrm{Eu}$. & 0.0195 & 221 & ${ }^{244} \mathrm{Cm}$ & 4.42 E- 05 & 0.502 \\
\hline${ }^{226} \mathrm{Ra}$ & $4.10 \mathrm{E}-08$ & $4.66 \mathrm{E}-04$ & & - & \\
\hline \multicolumn{6}{|c|}{$\begin{array}{l}\mathrm{NR}=\text { Not reported } \\
\text { SRR = Strontium recovery sludge } \\
{ }^{\mathrm{a}} \text { Composition based upon Hanford Defined Waste. } \\
{ }^{\mathrm{b}} \text { Based upon a volume of } 11.4 \mathrm{~kL} \text { of sludge in } 241-\mathrm{AX}-101 .\end{array}$} \\
\hline
\end{tabular}


Table 3. SMMA1 Saltcake Composition and Inventory Projections for Tank 241-AX-101 Based on Core Samples from Tanks 241-A-102 and 241-A-103 and Auger Samples from Tank 241-A-102 (page 1 of 2)

\begin{tabular}{|c|c|c|c|c|c|}
\hline \multirow[b]{2}{*}{ Anaiyte } & \multicolumn{2}{|c|}{ 241-A-102 Sample Data } & \multirow{2}{*}{$\begin{array}{c}\text { Tank } \\
241-\mathrm{A}-103 \\
\text { Core Sample } \\
\text { Data } \\
(\mu \mathrm{g} / \mathrm{g})^{\mathrm{b}}\end{array}$} & \multirow{2}{*}{$\begin{array}{c}\text { Average Analyte } \\
\text { Concentration in } \\
\text { SMMA A } \\
\text { Saltcake } \\
(\mu \mathrm{g} / \mathrm{g})\end{array}$} & \multirow{2}{*}{$\begin{array}{l}\text { Estimated } \\
\text { Inventory of } \\
\text { SMMAA saltcake } \\
\text { in tank } \\
241-\mathrm{AX}-101(\mathrm{~kg})\end{array}$} \\
\hline & $\begin{array}{c}1986 \text { Core } \\
\text { Sample } \\
(\mu \mathrm{g} / \mathrm{g})^{\mathrm{a}}\end{array}$ & $\begin{array}{c}1996 \text { Auger } \\
\text { Sample } \\
(\mu \mathrm{g} / \mathrm{g})^{2}\end{array}$ & & & \\
\hline Density & 1.59 & 1.7 & 1.345 & 1.495 & 1.495 \\
\hline $\mathrm{Ag}$ & 247 & 371 & 24.7 & 167 & 704 \\
\hline $\mathrm{Al}$ & 23,265 & 31,700 & 16,570 & 22,026 & 92,863 \\
\hline As & $\cdots \mathrm{NR}$ & NR & $\mathrm{NR}$ & NR & $\mathrm{NR}$ \\
\hline $\mathrm{B}$ & 14.2 & $\mathrm{NR}$ & 22.2 & 18 & 76.8 \\
\hline $\mathrm{Ba}$ & $\begin{array}{r}.882 \\
\end{array}$ & 139 & 575 & 543. & 2,289 \\
\hline $\mathrm{Bi}$ & 241,738 & 336 & 176 & 607 & 2,558 \\
\hline $\mathrm{Ca}$ & $\begin{array}{r}2,592 \\
\end{array}$ & 690 & 1,716 & 1,678 & 7,075 \\
\hline $\mathrm{Cd}$ & $-65-6$ & $\mathrm{NR}$ & $80 \ldots \ldots$ & $\ldots \cdots 72$ & $305 \ldots$ \\
\hline $\mathrm{Cl}$ & $\mathrm{NR}$ & $\mathrm{NR}$ & $\mathrm{NR}$ & $\mathrm{NR}$ & NR. \\
\hline $\mathrm{TIC}$ as $\mathrm{CO}_{3}$ & $\mathrm{NR}$ & 21,700 & NR & 21,700 & 91,487 \\
\hline $\mathrm{Cr}$ min & 5,270 & 8,800 & 1,531 & 4,283 & 18,057 \\
\hline $\mathrm{Cu}$ & 82.0 & $\mathrm{NR}$ & 12.3 & 47 & 199 \\
\hline $\mathrm{F}$ & $\mathrm{NR}$ & 277 & $\mathrm{NR}$ & 277 & 1,168 \\
\hline $\mathrm{Fe}$ & 13,936 & 19,600 & 355 & 8,561 & 36,095 \\
\hline $\mathrm{Hg}$ & $\mathrm{NR}$ & $\mathrm{NR}$ & $\mathrm{NR}$ & $\mathrm{NR}$ & $\mathrm{NR}$ \\
\hline $\mathrm{K}$ & 2,816 & 3,080 & 2,534 & 2,741 & 11,554 \\
\hline $\mathrm{Ga}$ & $\mathrm{NRS}$ & 103.0 & $\mathrm{NR}$ & 1,03 & 4342 \\
\hline $\mathrm{Mg}$ & 1,382 & $\mathrm{NR}$. & 795 & 1,088 & 4,589 \\
\hline $\mathrm{Mn}$ & 2,151 & 3,380 & 124 & 1,445 & 6,091 \\
\hline $\mathrm{Na}$ & 187,045 & 129,000 & 208,605 & 183,314 & 772,852 \\
\hline $\mathrm{Ni}$ & 526 & 41.3 & 93,3 & $281_{1:}$ & 1,186 \\
\hline $\mathrm{NO}_{2}$ & $\mathrm{NR}$ & 83,200 & $\mathrm{NR}$ & 83,200 & 350,772 \\
\hline $\mathrm{NO}_{3}$ & 178,500 & 90,300 & 113,500 & 123,950 & 522,574 \\
\hline $\mathrm{OH}$ & $\mathrm{NR}$ & $\mathrm{NR}$ & NR & $\mathrm{NR}$ & $\mathrm{NR}$ \\
\hline $\mathrm{Ph}$ & 1186 & 1.410 & 364 & $83 !$ & $3.5 n 3$ \\
\hline $\mathrm{P}$ as $\mathrm{PO}_{4}$ & 16,061 & 4,906 & $\mathrm{NR}$ & 10,483 & 44,198 \\
\hline $\mathrm{P}$ & 5,238 & $\mathrm{NR}$ & 2,170 & 3,704 & 15,617 \\
\hline $\mathrm{Se}$ & $\mathrm{NR}$ & NR & $\mathrm{NR}$ & $\mathrm{NR}$ & NR \\
\hline $\mathrm{Si}$ as $\mathrm{SiO}_{3}$ & 44,778 & 10,619 & 29,929 & 28,814 & 121,480 \\
\hline${\mathrm{S} \text { as } \mathrm{SO}_{4}}_{4}$ & $\mathrm{NR}$ & 4,480 & NR & 4,480 & 18,888 \\
\hline$S$ & $\mathrm{NR}$ & $\mathrm{NR}$ & $\mathrm{NR}$ & $\mathrm{NR}$ & $\mathrm{NR}$ \\
\hline
\end{tabular}


Table 3. SMMA1 Saltcake Composition and Inventory Projections for

Tank 241-AX-101 Based on Core Samples from Tanks 241-A-102 and 241-A-103 and Auger Samples from Tank 241-A-102 (page 2 of 2)

\begin{tabular}{|c|c|c|c|c|c|}
\hline \multirow[b]{2}{*}{ Analyte } & \multicolumn{2}{|c|}{ 241-A-102 Sample Data } & \multirow{2}{*}{$\begin{array}{c}\text { Tank } \\
241-A-103 \\
\text { Core Sample } \\
\text { Data } \\
(\mu g / g)^{b}\end{array}$} & \multirow{2}{*}{$\begin{array}{c}\text { Average Analyte } \\
\text { Concentration in } \\
\text { SMMA1 } \\
\text { Saltcake } \\
(\mu \mathrm{g} / \mathrm{g}) \\
\end{array}$} & \multirow{2}{*}{$\begin{array}{c}\text { Estimated } \\
\text { Inventory of } \\
\text { SMMA1 saltcake } \\
\text { in tank } \\
241-\mathrm{AX}-101(\mathrm{~kg})^{\mathrm{c}}\end{array}$} \\
\hline & $\begin{array}{c}1986 \text { Core } \\
\text { Sample } \\
(\mu g / g)^{2}\end{array}$ & $\begin{array}{c}1996 \text { Auger } \\
\text { Sample } \\
(\mu \mathrm{g} / \mathrm{g})^{\mathrm{a}}\end{array}$ & & & \\
\hline $\mathrm{Sr}$ & 97.6 & 31.5 & 12.0 & 38 & 161 \\
\hline TOC & 7,570 & 14,850 & 7,885 & 9,548 & 40,252 \\
\hline Total U & 1,041 & 35,300 & 1,435 & 9,803 & 41,327 \\
\hline $\mathrm{Zn}$ & 105 & NR & 54.0 & 79 & 335 \\
\hline $\mathrm{Zr}$ & 1,439 & NR & 209 & 824 & 3,474 \\
\hline EDTA & $\mathrm{NR}$ & NR & $\mathrm{NR}$ & $\mathrm{NR}$ & $\mathrm{NR}$ \\
\hline $\mathrm{NH}_{\text {itix }}$ & $\therefore N R_{3 \alpha}$ & $\therefore-i 2 N R_{2}=$ & $\mathrm{NR}$ & $\mathrm{NR}$ & $\therefore, i j=\mathrm{NR}$ \\
\hline $\mathrm{Cr}^{+6}$ & $\mathrm{NR}$ & and NRTES & 1.MNR snt & $120 \times 12 \times 2$ & S starive \\
\hline $\mathrm{CN}$ & NR & NR & NR & NR & NR \\
\hline $\mathrm{H}_{2} \mathrm{O}$ & 351,500 & 343,000 & 402,000 & 374,625 & $1,579,421$ \\
\hline $\begin{array}{l}\text { SMMA i } \\
\text { Volume (L) }\end{array}$ & 128,701 & & $1,374,075$ & & $2.82 \mathrm{e}+06$ \\
\hline $\begin{array}{l}\text { HDV } \\
\text { NR } \\
\text { SSR } \\
\text { SM } \\
\text { until } \\
\text { TCR } \\
\text { ajoe } \\
\text { 'Bas } \\
\text { 1988 } \\
\text { 'Bas } \\
\text { estin } \\
\text { and }\end{array}$ & $\begin{array}{l}=\text { Hanford De } \\
\text { Not reported } \\
=\text { Strontium rec } \\
\mathrm{A} 1=\text { Supernat } \\
980 \\
=\text { Tank Charac } \\
\text { al. (1996) } \\
\text { d on mean of } \\
\text { d on } 2,820 \mathrm{kI} \\
\text { te was derive } \\
\text { en averaging }\end{array}$ & $\begin{array}{l}\text { ined Waste } \\
\text { overy sludge } \\
\text { ant Mixing Mo } \\
\text { erization Repo } \\
\text { wo composite } \\
\text { of SMMA1 sal } \\
\text { by averaging } \\
\text { ie results for ta }\end{array}$ & $\begin{array}{l}\text { del 242-A Eva } \\
\text { it } \\
\text { core samples fi } \\
\text { tcake, with an } \\
\text { the core and au } \\
\text { mks } 241-\mathrm{A}-10\end{array}$ & $\begin{array}{l}\text { tank } 241-\mathrm{A}-103 \\
\text { rage density of } 1 \\
\text { sample results } \mathrm{fo} \\
\text { d } 241-\mathrm{A}-103 \text {. }\end{array}$ & $\begin{array}{l}\text { lerated from } 1976 \\
\text { (Weiss and Schull } \\
.495 \mathrm{~kg} / \mathrm{L} \text {. This } \\
\text { or tank } 241-\mathrm{A}-102 \text {, }\end{array}$ \\
\hline
\end{tabular}


Table 4. Analytical Resuits and Tank Inventory Estimates for

Radioactive Components in SMMA1 Saltcake in Tank 241-AX-101

Based on Core Samples from Tanks 241-A-102 and 241-A-103

\begin{tabular}{|c|c|c|c|c|c|}
\hline \multirow[b]{2}{*}{ Analyte } & \multicolumn{2}{|c|}{$\begin{array}{c}\text { Tank 241-A-102 Sample } \\
\text { Data }\end{array}$} & \multirow{2}{*}{$\begin{array}{c}\text { Tank } \\
\text { 241-A-103 } \\
\text { Core Sample } \\
\text { Data } \\
\text { uCi/g }\end{array}$} & \multirow{2}{*}{$\begin{array}{c}\text { Average } \\
\text { Aralyte } \\
\text { Concentration } \\
\text { in SMMA } \\
\text { Saltcake } \\
\mathrm{uCi} / \mathrm{g}\end{array}$} & \multirow{2}{*}{$\begin{array}{c}\text { Estimated } \\
\text { Inventory of } \\
\text { SMMA1 } \\
\text { saltcake in tank } \\
\text { 241-AX-103 } \\
\mathrm{Ci} \\
\end{array}$} \\
\hline & $\begin{array}{l}1986 \text { Core } \\
\text { Sample } \\
\mathrm{uCi} / \mathrm{g}\end{array}$ & $\begin{array}{l}1996 \text { Auger } \\
\text { Sample } \\
\text { uCi/g }\end{array}$ & & & \\
\hline Decay Date & $12 / 31 / 99$ & $12 / 31 / 99$ & $12 / 31 / 99$ & $12 / 31 / 99$ & $12 / 31 / 99$ \\
\hline${ }^{14} \mathrm{C}$ & 0.0011 & $\mathrm{NR}$ & 0.0026 & 0.0019 & 7.83 \\
\hline${ }^{60} \mathrm{Co}$ & 0.137 & $\mathrm{NR}$ & 0.015 & 0.0758 & 319 \\
\hline${ }^{90} \mathrm{Sr}$ & 436 & $\mathrm{NR}$ & 35.2 & 236 & 993,039 \\
\hline${ }^{80} \mathrm{Y}$ & 436 & $N R$ & 35.2 & 236 & 993,039 \\
\hline${ }^{99} \mathrm{Tc}$ & 0.100 & $\mathrm{NR}$ & 0.117 & 0.109 & 458 \\
\hline${ }^{129} \mathrm{I}$ & $3.90 \mathrm{e}-05$ & $\mathrm{NR}$ & $9.50 \mathrm{e}-06$ & $2.42 \mathrm{e}-05$ & 0.102 \\
\hline${ }^{137} \mathrm{Cs}$ & 101.8 & $\mathrm{NR}$ & 147 & 124 & 524,882 \\
\hline${ }^{137} \mathrm{mBa}$ & 96.3 & $\mathrm{NR}$ & 139 & 118 & $496,538^{\circ}$ \\
\hline${ }^{239 / 240} \mathrm{Pu}$ & 2.001 & NR & 0.130 & 1.065 & 4,491 \\
\hline${ }^{241} \mathrm{Am}$ & 1.185 & $\mathrm{NR}$ & 0.119 & 0.652 & 2,749 \\
\hline \multicolumn{6}{|c|}{$\begin{array}{l}\text { HDW }=\text { Hanford Defined Waste } \\
\text { NR }=\text { Not reported }\end{array}$} \\
\hline \multicolumn{6}{|c|}{ ostimate was derived by using the SMLAI concentrations! } \\
\hline
\end{tabular}


Table 5. Comparison of Sample and Process Based and Hanford Defined Waste Inventory Estimates for Nonradioactive Components in Tank 241-AX-101 (page 1 of 2)

\begin{tabular}{|c|c|c|}
\hline Analyte & HDW Model $(\mathrm{kg})^{2}$ & Sample and Process Based $(\mathrm{kg})^{b}$ \\
\hline Density & 1.54 & 1.494 \\
\hline Heat load (kW) & 10.39 & $4.19^{c}$ \\
\hline $\mathrm{Ag}$ & NR & $7.04 \mathrm{E}+02$ \\
\hline $\mathrm{Al}$ & $1.16 \mathrm{E}+05$ & $9.29 E+04$ \\
\hline As & NR & $\mathrm{NR}$ \\
\hline $\mathrm{B}$ & $\mathrm{NR}$ & $7.68 \mathrm{E}+01$ \\
\hline $\mathrm{Ba}$ & $\mathrm{NR}$ & $2.29 \mathrm{E}+03$ \\
\hline $\mathrm{Bi}$ & $6.54 \mathrm{E}+02$ & $2.56 \mathrm{E}+03$ \\
\hline $\mathrm{Ca}$ & $3.24 \mathrm{E}+03$ & $7.14 \mathrm{E}+03$ \\
\hline $\mathrm{Cd}$ & $\therefore \quad \mathrm{NR}$ & $3.05 \mathrm{E}+02$ \\
\hline $\mathrm{Cl}$ & $2.11 E+04$ & $2.16 \mathrm{E}+01$ \\
\hline TIC as $\mathrm{CO}_{3}$ & $7.92 \mathrm{E}+04$ & $9.17 \mathrm{E}+04$ \\
\hline $\mathrm{Cr}$ & $1.54 \mathrm{E}+04$ & $1.81 \mathrm{E}+04$ \\
\hline $\mathrm{Cu}$ & $\mathrm{NR}$ & $1.99 \mathrm{E}+02$ \\
\hline$F$ & $3.26 \mathrm{E}+03$ & $1.17 \mathrm{E}+03$ \\
\hline $\mathrm{Fe}$ & $8.37 \mathrm{E}+03$ & $3.69 \mathrm{E}+04$ \\
\hline $\mathrm{Hg}$ & $5.08 \mathrm{E}+00$ & $\mathrm{NR}$ \\
\hline $\mathrm{K}$ & $6.47 \mathrm{E}+03$ & $1.16 \mathrm{E}+04$ \\
\hline $\mathrm{La}$ & $7.86 \mathrm{E}+00$ & $4.34 \mathrm{E}+02$ \\
\hline $\mathrm{Mg}$ & $\mathrm{NR}$ & $4.59 \mathrm{E}+03$ \\
\hline $\mathrm{Mn}$ & $6.45 \mathrm{E}+02$ & $6.09 \mathrm{E}+03$ \\
\hline $\mathrm{Na}$ & $7.91 \mathrm{E}+05$ & $7.75 \mathrm{E}+05$ \\
\hline $\mathrm{Ni}$ & $8.82 \mathrm{E}+02$ & $1.19 E+03$ \\
\hline $\mathrm{NO}_{2}$ & $2.90 \mathrm{E}+05$ & $3.51 \mathrm{E}+05$ \\
\hline $\mathrm{NO}_{3}$ & $6.71 \mathrm{E}+05$ & $5.23 \mathrm{E}+05$ \\
\hline $\mathrm{OH}$ & $4.16 \mathrm{E}+05$ & $7.65 \mathrm{E}+02$ \\
\hline $\mathrm{Pb}$ & $7.18 \mathrm{E}+02$ & $3.50 \mathrm{E}+03$ \\
\hline $\mathrm{P}$ as $\mathrm{PO}_{4}$ & $2.25 \mathrm{E}+04$ & $4.42 \mathrm{E}+04$ \\
\hline $\mathrm{P}$ & $7.34 \mathrm{E}+03$ & $1.56 \mathrm{E}+04$ \\
\hline $\mathrm{Se}$ & $\mathrm{NR}$ & $\mathrm{NR}$ \\
\hline 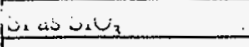 & $\therefore$ & 100 \\
\hline $\mathrm{S}$ as $\mathrm{SO}_{4}$ & $7.06 \mathrm{E}+04$ & $1.90 \mathrm{E}+04$ \\
\hline $\mathrm{S}$ & $2.36 E+04$ & $3.20 \mathrm{E}+01$ \\
\hline$S r$ & $7.48 \mathrm{E}+00$ & $1.61 \mathrm{E}+02$ \\
\hline TOC & $5.63 E+04$ & $4.09 \mathrm{E}+04$ \\
\hline Total U & $7.71 \mathrm{E}+03$ & $4.13 E+04$ \\
\hline
\end{tabular}


(format1y known as)

Table 6. Comparison of Sample and Process Based and Hanford Defined Waste Inventory Estimates for Radioactive Components in Tank 241-AX-101 (page 1 of 2)

\begin{tabular}{|c|c|c|}
\hline Analyte & HDW Model (Ci) & Sample and Process Based (Ci) \\
\hline Decay Date & $12 / 31 / 99$ & $12 / 31 / 99$ \\
\hline${ }^{3} \mathrm{H}$ & $4.46 \mathrm{E}+02$ & 9.43E-01 \\
\hline${ }^{14} \mathrm{C}$ & $9.87 \mathrm{E}+01$ & $7.91 \mathrm{E}+00$ \\
\hline${ }^{59} \mathrm{Ni}$ & $1.63 \mathrm{E}+01$ & $6.93 E+00$ \\
\hline${ }^{60} \mathrm{Co}$ & $5.76 \mathrm{E}+01$ & $3.20 \mathrm{E}+02$ \\
\hline${ }^{63} \mathrm{Ni}$ & $1.55 \mathrm{E}+03$ & $6.81 \mathrm{E}+02$ \\
\hline${ }^{79} \mathrm{Se}$ & $1.77 \mathrm{E}+01$ & $3.86 \mathrm{E}+00$ \\
\hline${ }^{90} \mathrm{Sr}$ & $8.83 E+05$ & $1.10 \mathrm{E}+06$ \\
\hline${ }^{90} \mathrm{Y}: \mathrm{m}: \mathrm{w}^{\mathrm{m}}$ & $8.83 \mathrm{E}+05$ & $1.10 E+06$ \\
\hline${ }^{93} \mathrm{mNb}$ & $2.20 \mathrm{E}+03$ & $1.43 \mathrm{E}+01$ \\
\hline $\begin{array}{ll}{ }_{93}^{93} \mathrm{Zr} \\
{ }^{2}\end{array}$ & $8.35 \mathrm{E}+01$ & $1.67 \mathrm{E}+01$ \\
\hline${ }^{99} \mathrm{Ten} 2 \mathrm{~m}$ & $7.53 \mathrm{E}+02$ & $4.58 \mathrm{E}+02$ \\
\hline${ }^{10.6} \mathrm{Ru}$ & $1.14 \mathrm{E}-03$ & $2.99 \mathrm{E}-02$ \\
\hline${ }^{113} \mathrm{mCd}$ & $2.84 \mathrm{E}+02$ & $3.55 \mathrm{E}+01$ \\
\hline${ }^{125} \mathrm{Sb}$ & $1.26 \mathrm{E}+02$ & 9.19E-01 \\
\hline${ }^{126} \mathrm{Sn}$ & $2.73 \mathrm{E}+01$ & $6.20 \mathrm{E}+00$ \\
\hline${ }^{129} \mathrm{Y}:$ & $1.45 \mathrm{E}+00$ & $1.03 \mathrm{E}-01$ \\
\hline${ }^{134} \mathrm{Cs}$ & $1.52 \mathrm{E}+00$ & $1.11 \mathrm{E}-01$ \\
\hline${ }^{135} \mathrm{Cs}$ & $\mathrm{NR}$ & $\mathrm{NR}$ \\
\hline \begin{tabular}{|lll}
${ }^{137} \mathrm{Cs}$ & $\vdots$ \\
\end{tabular} & $6.57 \mathrm{E}+05$ & $5.27 \mathrm{E}+05$ \\
\hline${ }^{137} \mathrm{mBa}$ & $6.21 \mathrm{E}+05$ & $4.98 \mathrm{E}+05$ \\
\hline${ }^{151} \mathrm{Sm}$ & $6.10 \mathrm{E}+04$ & $1.44 \mathrm{E}+04$ \\
\hline${ }^{152} \mathrm{Eu}$ & $1.57 \mathrm{E}+01$ & $3.61 \mathrm{E}+00$ \\
\hline${ }^{154} \mathrm{Eu}$ & $1.42 E+03$ & $8.49 \mathrm{E}+01$ \\
\hline${ }^{155} \mathrm{Eu}$ & $5.64 \mathrm{E}+02$ & $2.21 \mathrm{E}+02$ \\
\hline${ }^{226} \mathrm{Ra}$ & $1.10 \mathrm{E}-03$ & $4.66 \mathrm{E}-04$ \\
\hline${ }^{227} \mathrm{Ac}$ & $5.10 \mathrm{E}-03$ & $2.41 \mathrm{E}-03$ \\
\hline${ }^{228} \mathrm{Ra}$ & $4.97 \mathrm{E}-01$ & $2.11 \mathrm{E}-09$ \\
\hline${ }^{229} \mathrm{Th}$ & $2.35 \mathrm{E}-02$ & $3.51 \mathrm{E}-07$ \\
\hline${ }^{231} \mathrm{~Pa}$ & $1.80 \mathrm{E}-02$ & $3.60 \mathrm{E}-03$ \\
\hline${ }^{232} \mathrm{Th}$ & $1.10 \mathrm{E}-01$ & $2.85 \mathrm{E}-11$ \\
\hline${ }^{232} \mathrm{U}$ & $2.83 \mathrm{E}+00$ & $9.31 \mathrm{E}-08$ \\
\hline${ }^{233} \mathrm{U}:$ & $1.15 \mathrm{E}+01$ & $1.31 \mathrm{E}-09$ \\
\hline${ }^{234} \mathrm{U}$ & $1.84 \mathrm{E}+00$ & $3.90 \mathrm{E}-04$ \\
\hline${ }^{235} \mathrm{U}$ & $7.29 \mathrm{E}-02$ & $1.52 \mathrm{E}-05$ \\
\hline${ }^{236} \mathrm{U}$ & $5.93 \mathrm{E}-02$ & $2.57 \mathrm{E}-05$ \\
\hline${ }^{237} \mathrm{~Np}$ & $2.61 E+00$ & $1.65 \mathrm{E}-03$ \\
\hline
\end{tabular}


Table 6. Comparison of Sample and Process Based and Hanford Defined Waste Inventory Estimates for Radioactive Components in Tank 241-AX-101 (page 2 of 2)

\begin{tabular}{|l|c|c|}
\hline Analyte & HDW Model (Ci) & Sample and Process Based (Ci) \\
\hline Decay Date & $12 / 31 / 99$ & $12 / 31 / 99$ \\
\hline${ }^{238} \mathrm{Pu}$ & $1.23 \mathrm{E}+01$ & $5.42 \mathrm{E}+00$ \\
\hline${ }^{238} \mathrm{U}$ & $2.57 \mathrm{E}+00$ & $3.12 \mathrm{E}-04$ \\
\hline${ }^{239} \mathrm{Pu}$ & $3.68 \mathrm{E}+02$ & $3.79 \mathrm{E}+03$ \\
\hline${ }^{240} \mathrm{Pu}$ & $6.71 \mathrm{E}+01$ & $1.23 \mathrm{E}+03$ \\
\hline${ }^{239 / 240} \mathrm{Pu}$ & $4.35 \mathrm{E}+02$ & $5.02 \mathrm{E}+03$ \\
\hline${ }^{241} \mathrm{Am}$ & $4.62 \mathrm{E}+02$ & $2.91 \mathrm{E}+03$ \\
\hline${ }^{241} \mathrm{Pu}$ & $6.82 \mathrm{E}+02$ & $3.84 \mathrm{E}+02$ \\
\hline${ }^{242} \mathrm{Cm}$ & $6.27 \mathrm{E}-05$ & $1.37 \mathrm{E}-01$ \\
\hline${ }^{242} \mathrm{mAm}$ & $\mathrm{NR}$ & $\mathrm{NR}$ \\
\hline${ }^{242} \mathrm{Pu}$ & $5.22 \mathrm{E}-03$ & $2.26 \mathrm{E}-03$ \\
\hline${ }^{243} \mathrm{Am}$ & $8.57 \mathrm{E}-03$ \\
\hline${ }^{243} \mathrm{Cm}$ & $1.90 \mathrm{E}-02$ & $1.24 \mathrm{E}-02$ \\
\hline${ }^{244} \mathrm{Cm}$ & $5.45 \mathrm{E}-02$ & $5.02 \mathrm{E}-01$ \\
\hline $\mathrm{HDW}=$ Hanford Defined Waste & $9.11 \mathrm{E}-01$ & \\
\hline${ }^{2} \mathrm{P}$ Agnew et al. (1997a) & & \\
\hline
\end{tabular}

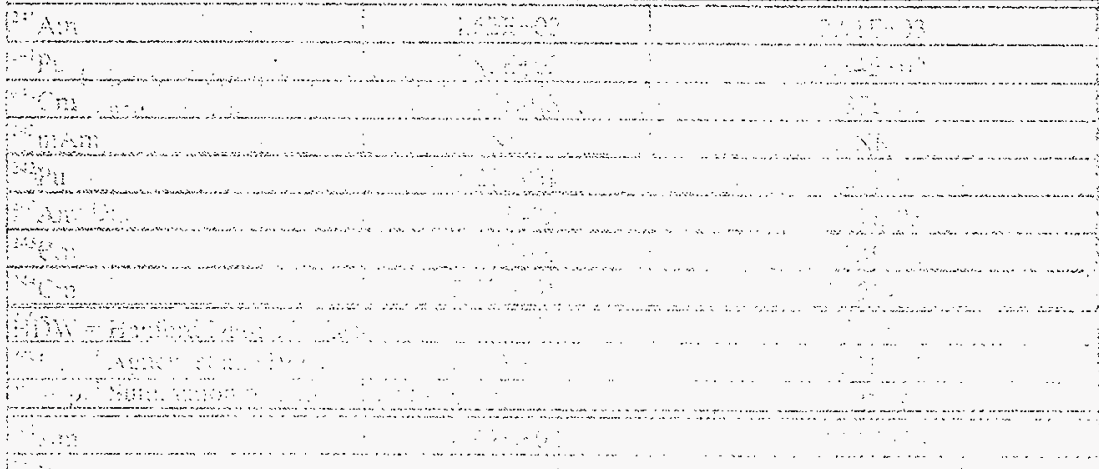


HNF-SD-HTI-TI-001, REV. 0

SESC-EN-RPT-002, Rev. 1

(formally known as)

Table 7. Waste Inventory of 241-AX-101 (Hanlon 1996)

\begin{tabular}{|l|c|c|}
\hline \multicolumn{1}{|c|}{ Waste } & Volume $(\mathrm{kL})$ & Volume (cubic feet) \\
\hline Sludge & 11 & 400 \\
\hline Saltcake & 2,820 & 99,450 \\
\hline Supernatant & 30 & 0 \\
\hline Drainable liquid & 1,211 & 42,720 \\
\hline Total waste & 2,831 & 99,850 \\
\hline
\end{tabular}


HNF-SD-HTI-TI-001, REV. O

SESC-EN-RPT-002, Rev. 1

(formally known as)

Table 8. Waste Transaction Information for Tank 241-AX-101 (Agnew et al. 1997b)

\begin{tabular}{|c|c|c|}
\hline Waste source & $\begin{array}{l}\text { Waste volume } \\
(\mathrm{kL})\end{array}$ & $\begin{array}{l}\text { Waste volume } \\
\text { (kgal) }\end{array}$ \\
\hline $\begin{array}{l}\text { PUREX HLW, organic wash waste, B Plant } \\
\text { Fission Product Waste }\end{array}$ & 3,198 & 845 \\
\hline B Plant Fission Product Waste & 12,933 & 3,417 \\
\hline Moved to tank A-102, AX-102, AX-103 & $-8,456$ & $-2,234$ \\
\hline PUREX HLW & 3,229 & 853 \\
\hline Moved to A-102, AX-102 & $-1,737$ & -459 \\
\hline PUREX acid waste after Sr removal at B Plant & 14,769 & 3,902 \\
\hline Moved to A-102, AX-103 & $-17,252$ & $-4,558$ \\
\hline PUREX sludge supernatant & 4,031 & 1,065 \\
\hline Moved to AX-103, $\mathrm{A}-103$ & $-3,274$ & -865 \\
\hline SRR waste $\quad y_{1}$ & 764 & 202 \\
\hline Tanksluiced to B Plant via AR Vault, AX-103 & $-2,055$ & -543 \\
\hline Sluiced tankempty except for $4.5 \mathrm{~kL}$ sludge heel & $\ldots$ & $\therefore \therefore$ \\
\hline EXAP & 3,622 & $-957 \div$ \\
\hline 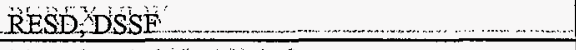 & 10,288 & $2,7,18$ \\
\hline 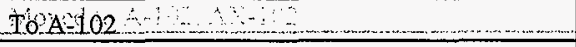 & $-10,746$ & $-2,839$ \\
\hline 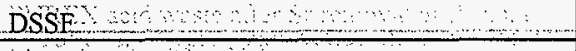 & 2,737 & 723 \\
\hline Moved to AW 103 & $-2,998$ & -792 \\
\hline Saltwell liquid moved to $\mathrm{AN}-103$ & -53 & -14 \\
\hline Total Waste Added post sluicing & $.16,646$ & 4,398 \\
\hline Tótal Waste Removed post sluicing & $-13,796 \ldots$ & $-3,645$ \\
\hline Current fruentory $\quad$, & $\cdots 2 ; 831 \ldots$ & $\therefore \quad \therefore 78 \quad \ldots$ \\
\hline \multicolumn{3}{|c|}{ 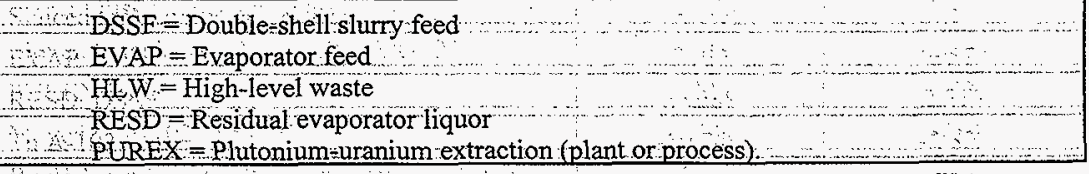 } \\
\hline
\end{tabular}


Table 9. Expected Solids for Tank 241-AX-101

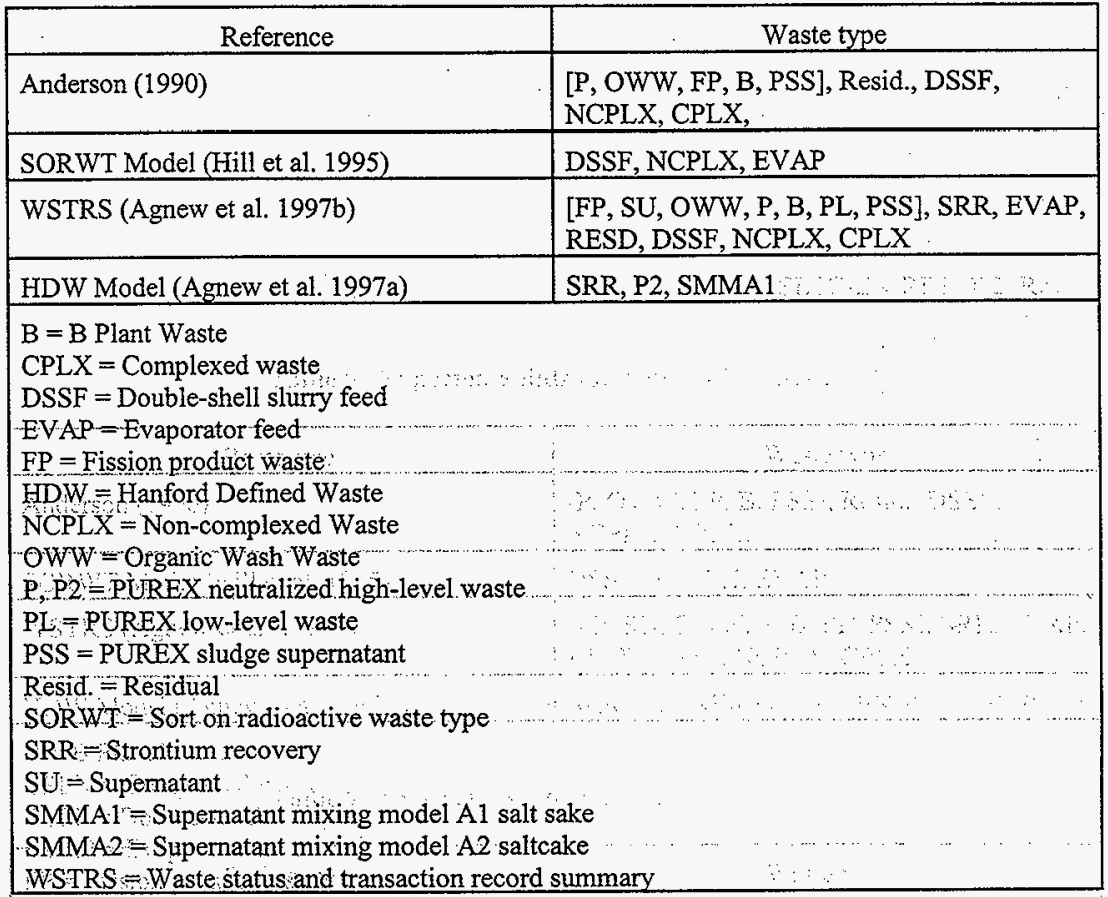


HNF-SD-HTI-TI-001, REV. 0

SESC-EN-RPT-002, Rev. 1

(formaily known as)

Table 10. Hanford Defined Waste Model Solids for Tank 241-AX-101

\begin{tabular}{|l|c|c|}
\hline Hanford Defined Waste solids layer & $\mathrm{kL}$ & $\mathrm{kgal}$ \\
\hline SRR & 11 & 3 \\
\hline P2 & 38 & 10 \\
\hline SMMA1 & 2,872 & 735 \\
\hline \multicolumn{2}{|c|}{ P2 = PUREX neutralized high-level waste } \\
$\begin{array}{l}\text { SMMA1 = Supernatant Mixing Model A1 saltcake } \\
\text { SRR }=\text { Strontium recovery waste. }\end{array}$ \\
\hline
\end{tabular}

Yos

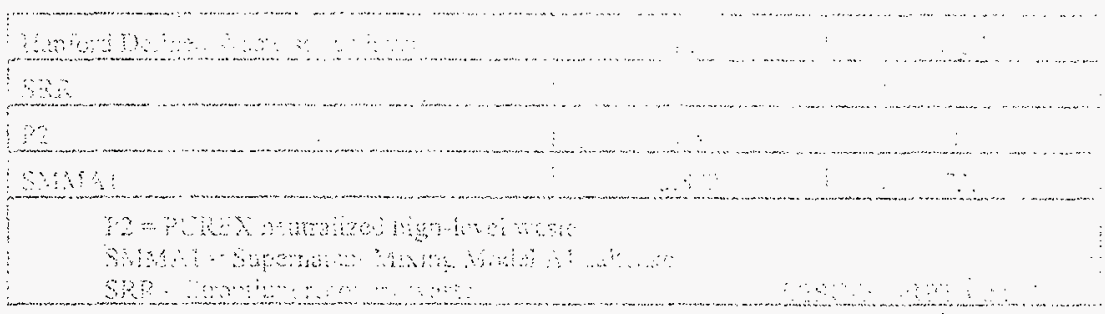


HNF-SD-HTI-TI-001, REV. 0

SESC-EN-RPT-002, Rev. 1

(forma17y known as)

Table 11. Relative Volume of Layers in Tanks 241-A-102 and 241-AX-101

\begin{tabular}{|c|c|c|c|c|}
\hline $\begin{array}{l}\text { Waste. } \\
\text { type }\end{array}$ & $\begin{array}{l}\text { Waste. Volume in. } \\
\text { Tank } 241-\mathrm{A}-102 \text {, } \\
\mathrm{kL}\end{array}$ & $\begin{array}{l}\text { Volume Percent in } \\
\text { Tank 241-A-102 }\end{array}$ & $\begin{array}{c}\text { Waste Volume in } \\
\text { Tank 241-AX-101, } \\
\text { kL }\end{array}$ & $\begin{array}{c}\text { Volume Percent } \\
\text { in Tank } \\
241-A X-101\end{array}$ \\
\hline SRR & 11.3 & 8.1 & 11.3 & 0.4 \\
\hline SMMA1 & 71.9 & 51 & 2,820 & 99.6 \\
\hline SMMA2 & 56.8 & 40 & 0 & 0 . \\
\hline
\end{tabular}


HNF-SD-HTI-TI-001, REV. 0

SESC-EN-RPT-002, Rev. 1

(formal 1y known as)

Table 12. Best-Basis. Inventory of Waste from Single-Shell Tank 241-AX-101 (page 1 of 2)

\begin{tabular}{|c|c|c|c|}
\hline & Sludge & Saltcake & Overall \\
\hline Density $\left(\mathrm{kg} / \mathrm{m}^{3}\right)$ & 1,690 & 1,495 & $\quad 1,496$ \\
\hline Volume $\left(\mathrm{m}^{3}\right)$ & 11.4 & $2,820.1$ & 2,831 \\
\hline \multicolumn{3}{|l|}{ Components (M) } & Inventory $(\mathrm{kg})$ \\
\hline $\mathrm{Ag}$ & NR & $2.31 \mathrm{E}-03$ & 703.7 \\
\hline $\mathrm{Al}$ & $8.26 \mathrm{E}+00$ & $1.22 \mathrm{E}+00$ & $95,393.7$ \\
\hline As & $\mathrm{NR}$ & $\mathrm{NR}$ & $\mathrm{NR}$ \\
\hline $\mathrm{B}$ & $\mathrm{NR}$ & $\mathrm{NR}$ & NR \\
\hline $\mathrm{Ba}$ & $7.00 \mathrm{E}-02$ & $5.91 \mathrm{E}-03$ & $2,398.1$ \\
\hline $\mathrm{Bi}$ & $\mathrm{NR}$ & $4.34 \mathrm{E}-03$ & $2,557.9$ \\
\hline $\mathrm{Ca}$ & $2.28 \mathrm{E}+00$ & $6.26 \mathrm{E}-02$ & $8,110.6$ \\
\hline $\mathrm{Cd}$ & $5.00 \mathrm{E}-02$ & $\therefore \mathrm{NR}$ & 63.8 \\
\hline $\mathrm{Cl} \quad \ldots \ldots$ & $5.37 \mathrm{E}-02 ;$ & $2.10 \mathrm{E}-01$ & $21,021.6$ \\
\hline TIC as $\mathrm{CO}_{3}$ & $3.41 \mathrm{E}-01$ & $5.41 \mathrm{E}-01$ & $91,719.9$ \\
\hline $\mathrm{Cr}$ & $2.03 \mathrm{E}-01$ & $1.23 \mathrm{E}-01$ & $18,177.0$ \\
\hline $\mathrm{Gu}$ & NR & $\mathrm{NR}$ & NR \\
\hline$F$ & $\mathrm{NR}$ & $2.18 \mathrm{E}-02$ & $1,167.8$ \\
\hline $\mathrm{Fe}$ & $1.90 \mathrm{E}+01$ & $2.29 \mathrm{E}-01$ & $48,129.9$ \\
\hline $\mathrm{Hg}$ & $\mathrm{NR}$ & $8.98 \mathrm{E}-06$ & 5.1 \\
\hline $\mathrm{K}$ & $1.17 \mathrm{E}-02$ & $1.05 \mathrm{E}-01$ & $11,559.7$ \\
\hline $\mathrm{La}$ & NR & $1.11 \mathrm{E}-03$ & $434: 2$ \\
\hline $\mathrm{Mg}$ & $5.70 \mathrm{E}-01$ & $\mathrm{NR}$ & 157.3 \\
\hline $\mathrm{Mn}$ & $2.82 \mathrm{E}-01$ & $3.93 \mathrm{E}-02$ & $6,267.1$ \\
\hline $\mathrm{Na}$ & $1.76 \mathrm{E}+01$ & $1.19 \mathrm{E}+01$ & $777,434.7$ \\
\hline $\mathrm{Ni}$ & 8.67E-01 & $7.17 \mathrm{E}-03$ & $1,764.1$ \\
\hline $\mathrm{NO}_{2}$ & $8.34 \mathrm{E}-01$ & $2.70 \mathrm{E}+00$ & $351,207.6$ \\
\hline $\mathrm{NO}_{3}$ & $4.10 \mathrm{E}+00$ & $2.99 \mathrm{E}+00$ & $525,460.9$ \\
\hline $\mathrm{OH}$ & $5.60 \mathrm{E}+01$ & $8.53 \mathrm{E}+00$ & $419,807.9$ \\
\hline $\mathrm{pb}$ & $\mathrm{NR}^{-1}$ & $5.99 \mathrm{E}-03$ & $3,502.7$ \\
\hline $\mathrm{P}_{\text {as }} \mathrm{PO}_{4}$ & $3.67 \mathrm{E}-01$ & $1.65 \mathrm{E}-01$ & $44,593.3$ \\
\hline $\mathrm{P}$ & $3.67 \mathrm{E}-01$ & $8.40 \mathrm{E}-02$ & $7,467.1$ \\
\hline $\mathrm{Se}$ & NR & $\mathrm{NR}$ & $\mathrm{NR}$ \\
\hline $\mathrm{Si}$ as $\mathrm{SiO}_{3}$ & $1.01 \mathrm{E}+01$ & $5.66 \mathrm{E}-01$ & $130 ; 193.8$ \\
\hline $\mathrm{S}$ as $\mathrm{SO}_{4}$ & $5.38 \mathrm{E}-01$ & $6.97 \mathrm{E}-02$ & $19,474.3$ \\
\hline S: & $5.38 \mathrm{E}-01$ & $2.58 \mathrm{E}-01$ & $23,558.9$ \\
\hline $\mathrm{Sr}$ & $\mathrm{NR}$ & $6.53 \mathrm{E}-04$ & 1613 \\
\hline $\mathrm{TOC}$ & $4.38 \mathrm{E}+00$ & $1.19 \mathrm{E}+00$ & $40,850.4$ \\
\hline Total U & $1.36 \mathrm{E}-05$ & $6.16 \mathrm{E}-02$ & $41 ; 327.5$ \\
\hline
\end{tabular}


Table 12. Best-Basis Inventory of Waste from Single-Shell Tank 241-AX-101 (page 2 of 2)

\begin{tabular}{|c|c|c|c|}
\hline & Sludge. & Saltcake & Overall \\
\hline Density $\left(\mathrm{kg} / \mathrm{m}^{3}\right)$ & 1,690 & 1,495 & 1,496 \\
\hline Volume $\left(\mathrm{m}^{3}\right)$ & 11.4 & $2,820.1$ & 2,831 \\
\hline \multicolumn{3}{|l|}{ Components (M) } & Inventory $(\mathrm{kg})$ \\
\hline $\mathrm{Zn}$ & NR & $\mathrm{NR}$ & NR \\
\hline $\mathrm{Zr}$ & $\mathrm{NR}$ & $8.59 \mathrm{E}-05$ & 22.1 \\
\hline EDTA & $1.29 \mathrm{E}-01$ & $3.18 \mathrm{E}-02$ & $26,628,4$ \\
\hline $\mathrm{NH}_{3}$ & $1.34 \mathrm{E}-01$ & $5.23 \mathrm{E}-02$ & $2,535.9$ \\
\hline $\mathrm{Cr}^{+6}$ & NR & NR & NR \\
\hline $\mathrm{CN}$ & $\mathrm{NR}$ & NR & NR \\
\hline $\mathrm{H}_{2} \mathrm{O}$ & $1.81 \mathrm{E}+02$ & $3.11 \mathrm{E}+01$ & $1,616,439.1$ \\
\hline Total & & $\therefore$ & $4.31 E+06$ \\
\hline \multicolumn{4}{|c|}{$\ldots, \mathrm{NR}:=$ Not reported } \\
\hline
\end{tabular}


HNF-SD-HTI-TI-001, REV， 0

SESC-EN-RPT-002, Rev. 1

(formally known as)

Table 13. Best-Basis Radionuclide Inventory Before Retrieval of Waste from Single-Shell Tank 241-AX-101 (page 1 of 2)

\begin{tabular}{|c|c|c|c|}
\hline Components $(\mathrm{Ci} / \mathrm{L})$ & SLUDGE & SALTCAKE & INVENTORY (CI) \\
\hline Decay Date & $12 / 31 / 99$ & $12 / 31 / 99$ & $12 / 31 / 99$ \\
\hline${ }^{3} \mathrm{H}$ & $8.30 \mathrm{E}-05$ & $\mathrm{NR}$ & $9.43 \mathrm{E}-01$ \\
\hline${ }^{14} \mathrm{C}$ & $6.77 \mathrm{E}-06$ & $2.78 \mathrm{E}-06$ & $7.91 \mathrm{E}+00$ \\
\hline${ }^{59} \mathrm{Ni}$ & $6.10 \mathrm{E}-04$ & $\mathrm{NR}$ & $6.93 E+00$ \\
\hline${ }^{60} \mathrm{Co}$ & 1.37E-05 & $1.13 \mathrm{E}-04$ & $3.20 \mathrm{E}+02$ \\
\hline${ }^{63} \mathrm{Ni}$ & $6.00 \mathrm{E}-02$ & $\mathrm{NR}$ & $6.81 \ddot{\mathrm{E}}+02$ \\
\hline${ }^{79} \mathrm{Se}$ & $3.40 \mathrm{E}-04$ & NR & $3.86 \mathrm{E}+00$ \\
\hline${ }^{90} \mathrm{Sx} \ldots$ & 9.57E+00 & $3.52 \mathrm{E}-01$ & $1.10 \mathrm{E}+06$ \\
\hline${ }^{90} \mathrm{Y}$ & $9.57 \mathrm{E}+00$ & $3.52 \mathrm{E}-01$ & $1.10 \mathrm{E}+06$ \\
\hline${ }^{93} \mathrm{mNb}$ & $1.26 \mathrm{E}-03$ & $\mathrm{NR}$ & $1.43 \mathrm{E}+01$ \\
\hline${ }^{93} \mathrm{Zr}$ & $1.47 \mathrm{E}-03$ & $\therefore \mathrm{NR}$ & $1.67 \mathrm{E}+01$ \\
\hline${ }^{99}$ Ten & $4.57 \mathrm{E}-05$ & $1.62 \mathrm{E}-04$ & $4.58 \mathrm{E}+02$ \\
\hline${ }^{106} \mathrm{Ru}$ & $2.63 \mathrm{E}-06$ & $\mathrm{NR}$ & $2.99 \mathrm{E}-02$ \\
\hline${ }^{113} \mathrm{mCd}$ & $3.13 \mathrm{E}-03$ & $\mathrm{NR}$ & $3.55 \mathrm{E}+01$ \\
\hline${ }^{125} \mathrm{Sb}$ & $8.09 \mathrm{E}-05$ & $\mathrm{NR}$ & 9.19E-01 \\
\hline${ }^{126} \mathrm{Sn}$ & $5.46 \mathrm{E}-04$ & $\mathrm{NR}$ & $6.20 \mathrm{E}+00$ \\
\hline${ }^{129} \mathrm{I}:$ & $8.89 \mathrm{E}-08$ & $3.63 \mathrm{E}-08$ & $1.03 \mathrm{E}-01$ \\
\hline${ }^{134} \mathrm{Cs}$ & $9.76 \mathrm{E}-06$ & $\mathrm{NR}$ & 1.11E-01 \\
\hline $135 \mathrm{Cs}$ & NR & $\mathrm{NR}$ & $\mathrm{NR}$ \\
\hline${ }^{137} \mathrm{Cs}$ & $1.77 \mathrm{E}=01$ & $1.86 \mathrm{E}-01$ & $5.27 \mathrm{E}+05$ \\
\hline${ }^{137} \mathrm{mBa}$ & 1.67E-01 & $1.76 \mathrm{E}-01$ & $4.98 \mathrm{E}+05$ \\
\hline${ }^{151} \mathrm{Sm}$ & $1.27 \mathrm{E}+00$ & $\mathrm{NR}$ & $1.44 \mathrm{E}+04$ \\
\hline${ }^{152} \mathrm{Eu}$ & $3.18 \mathrm{E}-04$ & $N R$ & $3.61 E+00$ \\
\hline${ }^{154} \mathrm{Eu}$ & $7.47 \mathrm{E}-03$ & $\mathrm{NR}$ & $8.49 \mathrm{E}+01$ \\
\hline $155 \mathrm{Eu}$ & $1.95 \mathrm{E}-02$ & $\mathrm{NR}$ & $2.21 \mathrm{E}+02$ \\
\hline${ }^{226} \mathrm{Ra}$ & $4.10 \mathrm{E}-08$ & $\mathrm{NR}$ & $4.66 \mathrm{E}-04$ \\
\hline${ }^{227} \mathrm{AC}$ & $2.12 \mathrm{E}-07$ & $\mathrm{NR}$ & $2.41 \mathrm{E}-03$ \\
\hline${ }^{228} \mathrm{Ra}$ & $1.86 \mathrm{E}-13$ & $\mathrm{NR}$ & $2.11 \mathrm{E}=09$ \\
\hline${ }^{229} \mathrm{Th}$ & $3.09 \mathrm{E}-11$ & $\mathrm{NR}$ & $3.51 \mathrm{E}-07$ \\
\hline${ }^{231} \mathrm{~Pa}$ & $3.17 \mathrm{E}-07$ & $\mathrm{NR}$ & $3.60 \mathrm{E}-03$ \\
\hline${ }^{232} \mathrm{Th}$ & $2.51 \mathrm{E}-15$ & NR: & $2.85 \mathrm{E}-11$ \\
\hline${ }^{232} \mathrm{U}$ & $8.20 \mathrm{E}-12$ & $\mathrm{NR}$ & $9.31 \mathrm{E}-08$ \\
\hline${ }^{233} \mathrm{U}$ & $115 \mathrm{E}-13$ & NR & $13: 1 \mathrm{E}-09$ \\
\hline $234 \mathrm{U}$ & $3.43 \mathrm{E}-0.8$ & $\mathrm{NR}$ & $3.90 \mathrm{E}-04$ \\
\hline${ }^{235} \mathrm{U}$ & $134 \mathrm{E}-09$ & $\mathrm{NR}$ & $1.52 \mathrm{E}-05$ \\
\hline${ }^{236} \mathrm{U}$ & $2.26 \mathrm{E}-09$ & $\mathrm{NR}$ & $2.57 \mathrm{E}-05$ \\
\hline Np & $1.45 \mathrm{E}-07$ & NR & $1.65 \mathrm{E}-03$ \\
\hline
\end{tabular}


Table 13. Best-Basis Radionuclide Inventory Before Retrieval of Waste from Single-Shell Tank 241-AX-101 (page 2 of 2)

\begin{tabular}{|l|c|c|c|}
\hline Components (Ci/L) & SLUDGE & SALTCAKE & INVENTORY (CI) \\
\hline Decay Date & $12 / 31 / 99$ & $12 / 31 / 99$ & $12 / 31 / 99$ \\
\hline${ }^{238} \mathrm{Pu}$ & $4.77 \mathrm{E}-04$ & NR & $5.42 \mathrm{E}+00$ \\
\hline${ }^{238} \mathrm{U}$ & $2.75 \mathrm{E}-08$ & NR & $3.12 \mathrm{E}-04$ \\
\hline${ }^{239} \mathrm{Pu}$ & $1.28 \mathrm{E}-02$ & $\mathrm{NR}$ & $1.45 \mathrm{E}+02$ \\
\hline${ }^{240} \mathrm{Pu}$ & $3.38 \mathrm{E}-02$ & $\mathrm{NR}$ & $3.84 \mathrm{E}+02$ \\
\hline${ }^{239240} \mathrm{Pu}$ & $4.66 \mathrm{E}-02$ & $1.59 \mathrm{E}-03$ & $5.02 \mathrm{E}+03$ \\
\hline${ }^{241} \mathrm{Am}$ & $1.44 \mathrm{E}-02$ & $9.75 \mathrm{E}-04$ & $2.91 \mathrm{E}+03$ \\
\hline${ }^{241} \mathrm{Pu}$ & $3.38 \mathrm{E}-02$ & $\mathrm{NR}$ & $3.84 \mathrm{E}+02$ \\
\hline${ }^{242} \mathrm{Cm}$ & $1.21 \mathrm{E}-05$ & NR & $1.37 \mathrm{E}-01$ \\
\hline${ }^{242} \mathrm{mAm}$ & $\mathrm{NR}$ & $\mathrm{NR}$ & $\mathrm{NR}$ \\
\hline${ }^{242} \mathrm{Pu}$ & $1.99 \mathrm{E}-07$ & $\mathrm{NR}$ & $2.26 \mathrm{E}-03$ \\
\hline${ }^{243} \mathrm{Am}$ & $7.55 \mathrm{E}-07$ & $\mathrm{NR}$ & $8.57 \mathrm{E}-03$ \\
\hline${ }^{243} \mathrm{Cm}$ & $1.09 \mathrm{E}-06$ & $\mathrm{NR}$ & $1.24 \mathrm{E}-02$ \\
\hline${ }^{244} \mathrm{Cm}$ & $4.42 \mathrm{E}-05$ & $\mathrm{NR}$ & $5.02 \mathrm{E}-01$ \\
\hline Total & & & $3.25 \mathrm{E}+06$ \\
\hline & & & \\
\hline
\end{tabular}


HNF-SD-HTI-TI-001, REV. 0

Table 14. Retrieval Scenario Summary of Residual Waste and Fractional Removal.

\begin{tabular}{|l|c|c|c|}
\hline & Case I & Case II & Case III \\
\hline Vol Base $\left(\mathrm{m}^{3}\right)$ & 101.94 & 10.19 & 1.02 \\
\hline$\%$ Base & $90.0 \%$ & $99.0 \%$ & $99.9 \%$ \\
\hline Target $\left(\mathrm{m}^{3}\right)$ & 101.94 & 10.19 & 1.02 \\
\hline Sludge $\left(\mathrm{m}^{3}\right)$ & 11.36 & 10.19 & 1.02 \\
\hline Saltcake $\left(\mathrm{m}^{3}\right)$ & 90.58 & 0.00 & 0.00 \\
\hline Sludge Remova1 & $0.0 \%$ & $10.2 \%$ & $91.0 \%$ \\
\hline SC Removal & $96.8 \%$ & $100.0 \%$ & $100.0 \%$ \\
\hline
\end{tabular}

s. 
(formality known as)

Table 15. Tank 241-AX-101 Nonradiological Waste Residual Inventory. Following Retrieval (page 1 of 2)

\begin{tabular}{|l|r|r|r|}
\hline Residual Waste $(\mathrm{kg})$ & Case I & Case II & Case III \\
\hline Target $\left(\mathrm{m}^{3}\right)$ & 101.94 & 10.19 & 1.02 \\
\hline Sludge $\left(\mathrm{m}^{3}\right)$ & 11.36 & 10.19 & 1.02 \\
\hline Saltcake $\left(\mathrm{m}^{3}\right)$ & 90.58 & 0.00 & 0.00 \\
\hline $\mathrm{Ag}$ & $2.26 \mathrm{E}+01$ & & \\
\hline $\mathrm{Al}$ & $5.51 \mathrm{E}+03$ & $2.27 \mathrm{E}+03$ & $2.27 \mathrm{E}+02$ \\
\hline As & NR & NR & NR \\
\hline $\mathrm{B}$ & $\mathrm{NR}$ & $\mathrm{NR}$ & $\mathrm{NR}$ \\
\hline $\mathrm{Ba}$ & $1.83 \mathrm{E}+02$ & $9.80 \mathrm{E}+01$ & $9.80 \mathrm{E}+00$ \\
\hline $\mathrm{Bi}$ & $8.22 \mathrm{E}+01$ & & \\
\hline $\mathrm{Ca}$ & $1.26 \mathrm{E}+03$ & $9.30 \mathrm{E}+02$ & $9.30 \mathrm{E}+01$ \\
\hline $\mathrm{Cd}$ & $6.38 \mathrm{E}+01$ & $5.73 \mathrm{E}+01$ & $5.73 \mathrm{E}+00$ \\
\hline $\mathrm{Cl}$ & $6.96 \mathrm{E}+02$ & $1.94 \mathrm{E}+01$ & $1.94 \mathrm{E}+00$ \\
\hline $\mathrm{TIC}$ as CO3 & $3.17 \mathrm{E}+03$ & $2.09 \mathrm{E}+02$ & $2.09 \mathrm{E}+01$ \\
\hline $\mathrm{Cr}$ & $7.00 \mathrm{E}+02$ & $1.08 \mathrm{E}+02$ & $1.08 \mathrm{E}+01$ \\
\hline $\mathrm{Cu}$ & $\mathrm{NR}$ & $\mathrm{NR}$ & $\mathrm{NR}$ \\
\hline $\mathrm{F}$ & $3.75 \mathrm{E}+01$ & & \\
\hline $\mathrm{Fe}$ & $1.32 \mathrm{E}+04$ & $1.08 \mathrm{E}+04$ & $1.08 \mathrm{E}+03$ \\
\hline $\mathrm{Hg}$ & $1.63 \mathrm{E}-01$ & & \\
\hline $\mathrm{K}$ & $3.76 \mathrm{E}+02$ & $4.65 \mathrm{E}+00$ & $4.65 \mathrm{E}-01$ \\
\hline $\mathrm{La}$ & $1.39 \mathrm{E}+01$ & & \\
\hline $\mathrm{Mg}$ & $1.57 \mathrm{E}+02$ & $1.41 \mathrm{E}+02$ & $1.41 \mathrm{E}+01$ \\
\hline $\mathrm{Mn}$ & $3.71 \mathrm{E}+02$ & $1.58 \mathrm{E}+02$ & $1.58 \mathrm{E}+01$ \\
\hline $\mathrm{Na}$ & $2.94 \mathrm{E}+04$ & $4.11 \mathrm{E}+03$ & $4.11 \mathrm{E}+02$ \\
\hline $\mathrm{Ni}$ & $6.16 \mathrm{E}+02$ & $5.19 \mathrm{E}+02$ & $5.19 \mathrm{E}+01$ \\
\hline $\mathrm{NO} 2$ & $1.17 \mathrm{E}+04$ & $3.91 \mathrm{E}+02$ & $3.91 \mathrm{E}+01$ \\
\hline $\mathrm{NO} 3$ & $1.97 \mathrm{E}+04$ & $2.59 \mathrm{E}+03$ & $2.59 \mathrm{E}+02$ \\
\hline $\mathrm{OH}$ & $2.39 \mathrm{E}+04$ & $9.70 \mathrm{E}+03$ & $9.70 \mathrm{E}+02$ \\
\hline $\mathrm{Pb}$ & $1.13 \mathrm{E}+02$ & & \\
\hline $\mathrm{P}$ as PO4 & $1.82 \mathrm{E}+03$ & $3.55 \mathrm{E}+02$ & $3.55 \mathrm{E}+01$ \\
\hline $\mathrm{P}$ & $3.65 \mathrm{E}+02$ & $1.16 \mathrm{E}+02$ & $1.16 \mathrm{E}+01$ \\
\hline $\mathrm{Se}$ & $\mathrm{NR}$ & $\mathrm{NR}$ & $\mathrm{NR}$ \\
\hline $\mathrm{Si}$ as SiO3 & $1.26 \mathrm{E}+04$ & $7.82 \mathrm{E}+03$ & $7.82 \mathrm{E}+02$ \\
\hline $\mathrm{S}$ as SO4 & $1.19 \mathrm{E}+03$ & $5.27 \mathrm{E}+02$ & $5.27 \mathrm{E}+01$ \\
\hline $\mathrm{S}$ & $9.46 \mathrm{E}+02$ & $1.76 \mathrm{E}+02$ & $1.76 \mathrm{E}+01$ \\
\hline $\mathrm{Sr}$ & $5.18 \mathrm{E}+00$ & & \\
\hline $\mathrm{TOC}$ & $1.89 \mathrm{E}+03$ & $5.37 \mathrm{E}+02$ & $5.37 \mathrm{E}+01$ \\
\hline $\mathrm{Total} \mathrm{U}$ & $1.33 \mathrm{E}+03$ & $3.30 \mathrm{E}-02$ & $3.30 \mathrm{E}-03$ \\
\hline
\end{tabular}


Table 15. Tank 241-AX-101 Nonradiological Waste Residual Inventory Following Retrieval (page 2 of 2)

\begin{tabular}{|l|c|c|c|}
\hline Residual Waste $(\mathrm{kg})$ & Case I & Case II & Case III \\
\hline $\mathrm{Zn}$ & $\mathrm{NR}$ & $\mathrm{NR}$ & $\mathrm{NR}$ \\
\hline $\mathrm{Zr}$ & $7.10 \mathrm{E}-01$ & & \\
\hline EDTA & $1.27 \mathrm{E}+03$ & $3.85 \mathrm{E}+02$ & $3.85 \mathrm{E}+01$ \\
\hline $\mathrm{NH} 3$ & $1.07 \mathrm{E}+02$ & $2.32 \mathrm{E}+01$ & $2.32 \mathrm{E}+00$ \\
\hline $\mathrm{Cr}+6$ & $\mathrm{NR}$ & $\mathrm{NR}$ & $\mathrm{NR}$ \\
\hline $\mathrm{CN}$ & $\mathrm{NR}$ & $\mathrm{NR}$ & $\mathrm{NR}$ \\
\hline H2O & $8.78 \mathrm{E}+04$ & $3.32 \mathrm{E}+04$ & $3.32 \mathrm{E}+03$ \\
\hline Tota1 & $2.19 \mathrm{E}+05$ & $7.50 \mathrm{E}+04$ & $7.50 \mathrm{E}+03$ \\
\hline
\end{tabular}


Table 16. Tank 241-AX-101 Radiological Waste Residual Inventory Following Retrieval (page 1 of 2)

\begin{tabular}{|l|c|c|c|}
\hline Residual Waste (Ci) & Case I & Case II & Case III \\
\hline Decay Date & $12 / 31 / 99$ & $12 / 31 / 99$ & $12 / 31 / 99$ \\
\hline $3 \mathrm{H}$ & $9.43 \mathrm{E}-01$ & $8.46 \mathrm{E}-01$ & $8.46 \mathrm{E}-02$ \\
\hline $14 \mathrm{C}$ & $7.69 \mathrm{E}-02$ & $6.90 \mathrm{E}-02$ & $6.90 \mathrm{E}-03$ \\
\hline $59 \mathrm{Ni}$ & $6.93 \mathrm{E}+00$ & $6.22 \mathrm{E}+00$ & $6.22 \mathrm{E}-01$ \\
\hline $60 \mathrm{Co}$ & $1.56 \mathrm{E}-01$ & $1.40 \mathrm{E}-01$ & $1.40 \mathrm{E}-02$ \\
\hline $63 \mathrm{Ni}$ & $6.81 \mathrm{E}+02$ & $6.12 \mathrm{E}+02$ & $6.12 \mathrm{E}+01$ \\
\hline $79 \mathrm{Se}$ & $3.86 \mathrm{E}+00$ & $3.47 \mathrm{E}+00$ & $3.47 \mathrm{E}-01$ \\
\hline $90 \mathrm{Sr}$ & $1.09 \mathrm{E}+05$ & $9.76 \mathrm{E}+04$ & $9.76 \mathrm{E}+03$ \\
\hline $90 \mathrm{Y}$ & $1.09 \mathrm{E}+05$ & $9.76 \mathrm{E}+04$ & $9.76 \mathrm{E}+03$ \\
\hline $93 \mathrm{mNb}$ & $1.43 \mathrm{E}+01$ & $1.28 \mathrm{E}+01$ & $1.28 \mathrm{E}+00$ \\
\hline $93 \mathrm{Zr}$ & $1.67 \mathrm{E}+01$ & $1.50 \mathrm{E}+01$ & $1.50 \mathrm{E}+00$ \\
\hline $99 \mathrm{Tc}$ & $5.19 \mathrm{E}-01$ & $4.66 \mathrm{E}-01$ & $4.66 \mathrm{E}-02$ \\
\hline $106 \mathrm{Ru}$ & $2.99 \mathrm{E}-02$ & $2.68 \mathrm{E}-02$ & $2.68 \mathrm{E}-03$ \\
\hline $113 \mathrm{mCd}$ & $3.55 \mathrm{E}+01$ & $3.19 \mathrm{E}+01$ & $3.19 \mathrm{E}+00$ \\
\hline $125 \mathrm{Sb}$ & $9.19 \mathrm{E}-01$ & $8.25 \mathrm{E}-01$ & $8.25 \mathrm{E}-02$ \\
\hline $126 \mathrm{Sn}$ & $6.20 \mathrm{E}+00$ & $5.57 \mathrm{E}+00$ & $-5.57 \mathrm{E}-01$ \\
\hline $129 \mathrm{I}$ & $1.01 \mathrm{E}-03$ & $9.06 \mathrm{E}-04$ & $9.06 \mathrm{E}-05$ \\
\hline $134 \mathrm{Cs}$ & $1.11 \mathrm{E}-01$ & $9.95 \mathrm{E}-02$ & $9.95 \mathrm{E}-03$ \\
\hline $135 \mathrm{Cs}$ & NR & NR & NR \\
\hline $137 \mathrm{Cs}$ & $2.01 \mathrm{E}+03$ & $1.80 \mathrm{E}+03$ & $1.80 \mathrm{E}+02$ \\
\hline $137 \mathrm{mBa}$ & $1.90 \mathrm{E}+03$ & $1.70 \mathrm{E}+03$ & $1.70 \mathrm{E}+02$ \\
\hline $151 \mathrm{Sm}$ & $1.44 \mathrm{E}+04$ & $1.30 \mathrm{E}+04$ & $1.30 \mathrm{E}+03$ \\
\hline $152 \mathrm{Eu}$ & $3.61 \mathrm{E}+00$ & $3.24 \mathrm{E}+00$ & $3.24 \mathrm{E}-01$ \\
\hline $154 \mathrm{Eu}$ & $8.49 \mathrm{E}+01$ & $7.62 \mathrm{E}+01$ & $7.62 \mathrm{E}+00$ \\
\hline $155 \mathrm{Eu}$ & $2.21 \mathrm{E}+02$ & $1.99 \mathrm{E}+02$ & $1.99 \mathrm{E}+01$ \\
\hline $226 \mathrm{Ra}$ & $4.66 \mathrm{E}-04$ & $4.18 \mathrm{E}-04$ & $4.18 \mathrm{E}-05$ \\
\hline $227 \mathrm{Ac}$ & $2.41 \mathrm{E}-03$ & $2.16 \mathrm{E}-03$ & $2.16 \mathrm{E}-04$ \\
\hline $228 \mathrm{Ra}$ & $2.11 \mathrm{E}-09$ & $1.90 \mathrm{E}-09$ & $1.90 \mathrm{E}-10$ \\
\hline $229 \mathrm{Th}$ & $3.51 \mathrm{E}-07$ & $3.15 \mathrm{E}-07$ & $3.15 \mathrm{E}-08$ \\
\hline $231 \mathrm{~Pa}$ & $3.60 \mathrm{E}-03$ & $3.23 \mathrm{E}-03$ & $3.23 \mathrm{E}-04$ \\
\hline $232 \mathrm{Th}$ & $2.85 \mathrm{E}-11$ & $2.56 \mathrm{E}-11$ & $2.56 \mathrm{E}-12$ \\
\hline $232 \mathrm{U}$ & $9.31 \mathrm{E}-08$ & $8.36 \mathrm{E}-08$ & $8.36 \mathrm{E}-09$ \\
\hline $233 \mathrm{U}$ & $1.31 \mathrm{E}-09$ & $1.17 \mathrm{E}-09$ & $1.17 \mathrm{E}-10$ \\
\hline $234 \mathrm{U}$ & $3.90 \mathrm{E}-04$ & $3.50 \mathrm{E}-04$ & $3.50 \mathrm{E}-05$ \\
\hline $235 \mathrm{U}$ & $1.52 \mathrm{E}-05$ & $1.37 \mathrm{E}-05$ & $1.37 \mathrm{E}-06$ \\
\hline $236 \mathrm{U}$ & $2.57 \mathrm{E}-05$ & $2.30 \mathrm{E}-05$ & $2.30 \mathrm{E}-06$ \\
\hline $237 \mathrm{~Np}$ & $1.65 \mathrm{E}-03$ & $1.48 \mathrm{E}-03$ & $1.48 \mathrm{E}-04$ \\
\hline & & & \\
\hline & & & \\
\hline & & & \\
\hline & & &
\end{tabular}


HNF-SD-HTI-TI-001, REV. 0

SESC-EN-RPT-002. Rev. 1

(formally known as)

Table 16. Tank 241-AX-101 Radiological Waste Residual Inventory

Following Retrieval (page 2 of 2)

\begin{tabular}{|l|c|c|c|}
\hline Residual Waste (Ci) & Case I & Case II & Case III \\
\hline Decay Date & $12 / 31 / 99$ & $12 / 31 / 99$ & $12 / 31 / 99$ \\
\hline $238 \mathrm{Pu}$ & $5.42 \mathrm{E}+00$ & $4.86 \mathrm{E}+00$ & $4.86 \mathrm{E}-01$ \\
\hline $238 \mathrm{U}$ & $3.12 \mathrm{E}-04$ & $2.80 \mathrm{E}-04$ & $2.80 \mathrm{E}-05$ \\
\hline $239 \mathrm{Pu}$ & $1.45 \mathrm{E}+02$ & $1.30 \mathrm{E}+02$ & $1.30 \mathrm{E}+01$ \\
\hline $240 \mathrm{Pu}$ & $3.84 \mathrm{E}+02$ & $3.44 \mathrm{E}+02$ & $3.44 \mathrm{E}+01$ \\
\hline $239 / 240 \mathrm{Pu}$ & $5.29 \mathrm{E}+02$ & $4.75 \mathrm{E}+02$ & $4.75 \mathrm{E}+01$ \\
\hline $241 \mathrm{Am}$ & $1.64 \mathrm{E}+02$ & $1.47 \mathrm{E}+02$ & $1.47 \mathrm{E}+01$ \\
\hline $241 \mathrm{Pu}$ & $3.84 \mathrm{E}+02$ & $3.44 \mathrm{E}+02$ & $3.44 \mathrm{E}+01$ \\
\hline $242 \mathrm{Cm}$ & $1.37 \mathrm{E}-01$ & $1.23 \mathrm{E}-01$ & $1.23 \mathrm{E}-02$ \\
\hline $242 \mathrm{mAm}$ & NR & NR & NR \\
\hline $242 \mathrm{Pu}$ & $2.26 \mathrm{E}-03$ & $2.03 \mathrm{E}-03$ & $2.03 \mathrm{E}-04$ \\
\hline $243 \mathrm{Am}$ & $8.57 \mathrm{E}-03$ & $7.70 \mathrm{E}-03$ & $7.70 \mathrm{E}-04$ \\
\hline $243 \mathrm{Cm}$ & $1.24 \mathrm{E}-02$ & $1.11 \mathrm{E}-02$ & $1.11 \mathrm{E}-03$ \\
\hline $244 \mathrm{Cm}$ & $5.02 \mathrm{E}-01$ & $4.51 \mathrm{E}-01$ & $4.51 \mathrm{E}-02$ \\
\hline Total & $2.38 \mathrm{E}+05$ & $2.14 \mathrm{E}+05$ & $2.14 \mathrm{E}+04$ \\
\hline
\end{tabular}


Table 17. Retrieval Scenario Product Solution Nonradiological Analyte Concentrations (page 1 of 2).

\begin{tabular}{|l|c|r|r|}
\hline Limiting Vol (L) & $6,507,475$ & $6,727,521$ & $6,759,731$ \\
\hline Sludge [Solids Basis (L)] & 0 & 40,344 & 358,900 \\
\hline Saltcake [Na Basis (L)] & $6,507,475$ & $6,727,521$ & $6,759,731$ \\
\hline Solution Concentrations (M) & Case 1 & Case II & Case III \\
\hline $\mathrm{Ag}$ & $9.70 \mathrm{E}-04$ & $9.70 \mathrm{E}-04$ & $9.65 \mathrm{E}-04$ \\
\hline $\mathrm{Al}$ & $5.12 \mathrm{E}-01$ & $5.13 \mathrm{E}-01$ & $5.22 \mathrm{E}-01$ \\
\hline $\mathrm{As}$ & & & \\
\hline $\mathrm{B}$ & & & \\
\hline $\mathrm{Ba}$ & $2.48 \mathrm{E}-03$ & $2.49 \mathrm{E}-03$ & $2.57 \mathrm{E}-03$ \\
\hline $\mathrm{Bi}$ & $1.82 \mathrm{E}-03$ & $1.82 \mathrm{E}-03$ & $1.81 \mathrm{E}-03$ \\
\hline $\mathrm{Ca}$ & $2.63 \mathrm{E}-02$ & $2.66 \mathrm{E}-02$ & $2.96 \mathrm{E}-02$ \\
\hline $\mathrm{Cd}$ & $1.49 \mathrm{E}-18$ & $8.64 \mathrm{E}-06$ & $7.65 \mathrm{E}-05$ \\
\hline $\mathrm{Cl}$ & $8.81 \mathrm{E}-02$ & $8.81 \mathrm{E}-02$ & $8.77 \mathrm{E}-02$ \\
\hline $\mathrm{TIC}$ as CO3 & $2.27 \mathrm{E}-01$ & $2.27 \mathrm{E}-01$ & $2.26 \mathrm{E}-01$ \\
\hline $\mathrm{Cr}$ & $5.17 \mathrm{E}-02$ & $5.17 \mathrm{E}-02$ & $5.17 \mathrm{E}-02$ \\
\hline $\mathrm{Cu}$ & & & \\
\hline $\mathrm{F}$ & $9.14 \mathrm{E}-03$ & $9.14 \mathrm{E}-03$ & $9.09 \mathrm{E}-03$ \\
\hline $\mathrm{Fe}$ & $9.61 \mathrm{E}-02$ & $9.93 \mathrm{E}-02$ & $1.25 \mathrm{E}-01$ \\
\hline $\mathrm{Hg}$ & $3.77 \mathrm{E}-06$ & $3.76 \mathrm{E}-06$ & $3.75 \mathrm{E}-06$ \\
\hline $\mathrm{K}$ & $4.40 \mathrm{E}-02$ & $4.39 \mathrm{E}-02$ & $4.37 \mathrm{E}-02$ \\
\hline $\mathrm{La}$ & $4.65 \mathrm{E}-04$ & $4.65 \mathrm{E}-04$ & $4.62 \mathrm{E}-04$ \\
\hline $\mathrm{Mg}$ & $1.70 \mathrm{E}-17$ & $9.84 \mathrm{E}-05$ & $8.72 \mathrm{E}-04$ \\
\hline $\mathrm{Mn}$ & $1.65 \mathrm{E}-02$ & $1.65 \mathrm{E}-02$ & $1.68 \mathrm{E}-02$ \\
\hline $\mathrm{Na}$ & $5.00 \mathrm{E}+00$ & $5.00 \mathrm{E}+00$ & $5.00 \mathrm{E}+00$ \\
\hline $\mathrm{Ni}$ & $3.01 \mathrm{E}-03$ & $3.15 \mathrm{E}-03$ & $4.32 \mathrm{E}-03$ \\
\hline $\mathrm{NO} 2$ & $1.13 \mathrm{E}+00$ & $1.13 \mathrm{E}+00$ & $1.13 \mathrm{E}+00$ \\
\hline $\mathrm{NO} 3$ & $1.25 \mathrm{E}+00$ & $1.25 \mathrm{E}+00$ & $1.25 \mathrm{E}+00$ \\
\hline $\mathrm{OH}$ & $3.58 \mathrm{E}+00$ & $3.58 \mathrm{E}+00$ & $3.64 \mathrm{E}+00$ \\
\hline $\mathrm{Pb}$ & $2.51 \mathrm{E}-03$ & $2.51 \mathrm{E}-03$ & $2.50 \mathrm{E}-03$ \\
\hline $\mathrm{P}$ as PO4 & $6.92 \mathrm{E}-02$ & $6.92 \mathrm{E}-02$ & $6.94 \mathrm{E}-02$ \\
\hline $\mathrm{P}$ & $3.52 \mathrm{E}-02$ & $3.53 \mathrm{E}-02$ & $3.56 \mathrm{E}-02$ \\
\hline $\mathrm{Se}$ & & & \\
\hline $\mathrm{Si}$ as SiO3 & $2.37 \mathrm{E}-01$ & $2.39 \mathrm{E}-01$ & $2.52 \mathrm{E}-01$ \\
\hline $\mathrm{S}$ as SO4 & $2.92 \mathrm{E}-02$ & $2.93 \mathrm{E}-02$ & $2.99 \mathrm{E}-02$ \\
\hline $\mathrm{S}$ & $1.08 \mathrm{E}-01$ & $1.08 \mathrm{E}-01$ & $1.09 \mathrm{E}-01$ \\
\hline $\mathrm{Sr}$ & $2.74 \mathrm{E}-04$ & $2.74 \mathrm{E}-04$ & $2.72 \mathrm{E}-04$ \\
\hline $\mathrm{TOC}$ & $4.98 \mathrm{E}-01$ & $4.99 \mathrm{E}-01$ & $5.02 \mathrm{E}-01$ \\
\hline
\end{tabular}


HNF-SD-HTI-TI-001, REV. 0

SESC-EN-RPT-002, Rev. 1

Table 17. Retrieval Scenario Product Solution

(formally known as)

Nonradiological Analyte Concentrations (page 2 of 2)

\begin{tabular}{|l|r|r|r|}
\hline Limiting Vol (L) & $6,507,475$ & $6,727,521$ & $6,759,731$ \\
\hline Sludge [Solids Basis (L)] & 0 & 40,344 & 358,900 \\
\hline Saltcake [Na Basis (L)] & $6,507,475$ & $6,727,521$ & $6,759,731$ \\
\hline Solution Concentrations (M) & Case I & Case II & Case III \\
\hline Total U & $2.58 \mathrm{E}-02$ & $2.58 \mathrm{E}-02$ & $2.57 \mathrm{E}-02$ \\
\hline $\mathrm{Zn}$ & & & \\
\hline $\mathrm{Zr}$ & $3.60 \mathrm{E}-05$ & $3.60 \mathrm{E}-05$ & $3.58 \mathrm{E}-05$ \\
\hline EDTA & $1.33 \mathrm{E}-02$ & $1.33 \mathrm{E}-02$ & $1.35 \mathrm{E}-02$ \\
\hline $\mathrm{NH} 3$ & $2.19 \mathrm{E}-02$ & $2.19 \mathrm{E}-02$ & $2.20 \mathrm{E}-02$ \\
\hline $\mathrm{Cr}+6$ & & & \\
\hline $\mathrm{CN}$ & & & \\
\hline H2O & 13.04 & 13.06 & 13.25 \\
\hline Retrieval H2O & 32.23 & 32.23 & 32.27 \\
\hline
\end{tabular}


Table 18. Retrieval Scenario Product Solution Radiological Analyte Concentrations (page 1 of 2)

\begin{tabular}{|l|c|c|c|}
\hline Solution Concentrations (Ci/L) & Case I & Case II & Case III \\
\hline Decay Date & $12 / 31 / 99$ & $12 / 31 / 99$ & $12 / 31 / 99$ \\
\hline $3 \mathrm{H}$ & $2.47 \mathrm{E}-21$ & $1.43 \mathrm{E}-08$ & $1.27 \mathrm{E}-07$ \\
\hline $14 \mathrm{C}$ & $1.16 \mathrm{E}-06$ & $1.17 \mathrm{E}-06$ & $1.17 \mathrm{E}-06$ \\
\hline $59 \mathrm{Ni}$ & $1.81 \mathrm{E}-20$ & $1.05 \mathrm{E}-07$ & $9.33 \mathrm{E}-07$ \\
\hline $60 \mathrm{Co}$ & $4.75 \mathrm{E}-05$ & $4.75 \mathrm{E}-05$ & $4.73 \mathrm{E}-05$ \\
\hline $63 \mathrm{Ni}$ & $1.79 \mathrm{E}-18$ & $1.04 \mathrm{E}-05$ & $9.18 \mathrm{E}-05$ \\
\hline $79 \mathrm{Se}$ & $1.01 \mathrm{E}-20$ & $5.87 \mathrm{E}-08$ & $5.20 \mathrm{E}-07$ \\
\hline $90 \mathrm{Sr}$ & $1.48 \mathrm{E}-01$ & $1.49 \mathrm{E}-01$ & $1.62 \mathrm{E}-01$ \\
\hline $90 \mathrm{Y}$ & $1.48 \mathrm{E}-01$ & $1.49 \mathrm{E}-01$ & $1.62 \mathrm{E}-01$ \\
\hline $93 \mathrm{mNb}$ & $3.75 \mathrm{E}-20$ & $2.18 \mathrm{E}-07$ & $1.93 \mathrm{E}-06$ \\
\hline $93 \mathrm{Zr}$ & $4.37 \mathrm{E}-20$ & $2.54 \mathrm{E}-07$ & $2.25 \mathrm{E}-06$ \\
\hline $99 \mathrm{Tc}$ & $6.81 \mathrm{E}-05$ & $6.81 \mathrm{E}-05$ & $6.78 \mathrm{E}-05$ \\
\hline $106 \mathrm{Ru}$ & $7.83 \mathrm{E}-23$ & $4.54 \mathrm{E}-10$ & $4.02 \mathrm{E}-09$ \\
\hline $113 \mathrm{mCd}$ & $9.31 \mathrm{E}-20$ & $5.41 \mathrm{E}-07$ & $4.79 \mathrm{E}-06$ \\
\hline $125 \mathrm{Sb}$ & $2.41 \mathrm{E}-21$ & $1.40 \mathrm{E}-08$ & $1.24 \mathrm{E}-07$ \\
\hline $126 \mathrm{Si}$ & $1.62 \mathrm{E}-20$ & $9.43 \mathrm{E}-08$ & $8.35 \mathrm{E}-07$ \\
\hline $129 \mathrm{I}$ & $1.52 \mathrm{E}-08$ & $1.52 \mathrm{E}-08$ & $1.53 \mathrm{E}-08$ \\
\hline $134 \mathrm{Cs}$ & $2.90 \mathrm{E}-22$ & $1.69 \mathrm{E}-09$ & $1.49 \mathrm{E}-08$ \\
\hline $135 \mathrm{Cs}$ & & & \\
\hline $137 \mathrm{Cs}$ & $7.81 \mathrm{E}-02$ & $7.81 \mathrm{E}-02$ & $7.79 \mathrm{E}-02$ \\
\hline $137 \mathrm{mBa}$ & $7.39 \mathrm{E}-02$ & $7.38 \mathrm{E}-02$ & $7.37 \mathrm{E}-02$ \\
\hline $151 \mathrm{Sm}$ & $3.78 \mathrm{E}-17$ & $2.20 \mathrm{E}-04$ & $1.94 \mathrm{E}-03$ \\
\hline $152 \mathrm{Eu}$ & $9.46 \mathrm{E}-21$ & $5.49 \mathrm{E}-08$ & $4.86 \mathrm{E}-07$ \\
\hline $154 \mathrm{Eu}$ & $2.22 \mathrm{E}-19$ & $1.29 \mathrm{E}-06$ & $1.14 \mathrm{E}-05$ \\
\hline $155 \mathrm{Eu}$ & $5.80 \mathrm{E}-19$ & $3.37 \mathrm{E}-06$ & $2.98 \mathrm{E}-05$ \\
\hline $226 \mathrm{Ra}$ & $1.22 \mathrm{E}-24$ & $7.08 \mathrm{E}-12$ & $6.27 \mathrm{E}-11$ \\
\hline $227 \mathrm{Ac}$ & $6.31 \mathrm{E}-24$ & $3.66 \mathrm{E}-11$ & $3.24 \mathrm{E}-10$ \\
\hline $228 \mathrm{Ra}$ & $5.53 \mathrm{E}-30$ & $3.21 \mathrm{E}-17$ & $2.84 \mathrm{E}-16$ \\
\hline $229 \mathrm{Th}$ & $9.19 \mathrm{E}-28$ & $5.34 \mathrm{E}-15$ & $4.73 \mathrm{E}-14$ \\
\hline $231 \mathrm{~Pa}$ & $9.43 \mathrm{E}-24$ & $5.47 \mathrm{E}-11$ & $4.85 \mathrm{E}-10$ \\
\hline $232 \mathrm{Th}$ & $7.47 \mathrm{E}-32$ & $4.34 \mathrm{E}-19$ & $3.84 \mathrm{E}-18$ \\
\hline $232 \mathrm{U}$ & $2.44 \mathrm{E}-28$ & $1.42 \mathrm{E}-15$ & $1.25 \mathrm{E}-14$ \\
\hline $233 \mathrm{U}$ & $3.42 \mathrm{E}-30$ & $1.99 \mathrm{E}-17$ & $1.76 \mathrm{E}-16$ \\
\hline $234 \mathrm{U}$ & $1.02 \mathrm{E}-24$ & $5.92 \mathrm{E}-12$ & $5.24 \mathrm{E}-11$ \\
\hline $235 \mathrm{U}$ & $3.99 \mathrm{E}-26$ & $2.31 \mathrm{E}-13$ & $2.05 \mathrm{E}-12$ \\
\hline $236 \mathrm{U}$ & $6.72 \mathrm{E}-26$ & $3.90 \mathrm{E}-13$ & $3.46 \mathrm{E}-12$ \\
\hline $237 \mathrm{~Np}$ & $4.31 \mathrm{E}-24$ & $2.50 \mathrm{E}-11$ & $2.22 \mathrm{E}-10$ \\
\hline & & & \\
\hline & & & \\
\hline & & &
\end{tabular}


Table 18. Retrieval Scenario Product Solution Radiological Analyte Concentrations (page 2 of 2)

\begin{tabular}{|l|c|c|c|}
\hline Solution Concentrations (Ci $/ \mathrm{L})$ & Case I & Case II & Case III \\
\hline Decay Date & $12 / 31 / 99$ & $12 / 31 / 99$ & $12 / 31 / 99$ \\
\hline $238 \mathrm{Pu}$ & $1.42 \mathrm{E}-20$ & $8.24 \mathrm{E}-08$ & $7.29 \mathrm{E}-07$ \\
\hline $238 \mathrm{U}$ & $8.18 \mathrm{E}-25$ & $4.75 \mathrm{E}-12$ & $4.21 \mathrm{E}-11$ \\
\hline $239 \mathrm{Pu}$ & $3.81 \mathrm{E}-19$ & $2.21 \mathrm{E}-06$ & $1.96 \mathrm{E}-05$ \\
\hline $240 \mathrm{Pu}$ & $1.01 \mathrm{E}-18$ & $5.84 \mathrm{E}-06$ & $5.17 \mathrm{E}-05$ \\
\hline $239 / 240 \mathrm{Pu}$ & $6.68 \mathrm{E}-04$ & $6.76 \mathrm{E}-04$ & $7.36 \mathrm{E}-04$ \\
\hline $241 \mathrm{Am}$ & $4.09 \mathrm{E}-04$ & $4.11 \mathrm{E}-04$ & $4.29 \mathrm{E}-04$ \\
\hline $241 \mathrm{Pu}$ & $1.01 \mathrm{E}-18$ & $5.84 \mathrm{E}-06$ & $5.17 \mathrm{E}-05$ \\
\hline $242 \mathrm{Cm}$ & $3.60 \mathrm{E}-22$ & $2.09 \mathrm{E}-09$ & $1.85 \mathrm{E}-08$ \\
\hline $242 \mathrm{mAm}$ & & & \\
\hline $242 \mathrm{Pu}$ & $5.92 \mathrm{E}-24$ & $3.44 \mathrm{E}-11$ & $3.04 \mathrm{E}-10$ \\
\hline $243 \mathrm{Am}$ & $2.25 \mathrm{E}-23$ & $1.30 \mathrm{E}-10$ & $1.15 \mathrm{E}-09$ \\
\hline $243 \mathrm{Cm}$ & $3.24 \mathrm{E}-23$ & $1.88 \mathrm{E}-10$ & $1.67 \mathrm{E}-09$ \\
\hline $244 \mathrm{Cm}$ & $1.32 \mathrm{E}-21$ & $7.63 \mathrm{E}-09$ & $6.76 \mathrm{E}-08$ \\
\hline
\end{tabular}


Table 19. Tank 241-AX-101 Retrieval Scenario Nonradiological Constituent Leakage Estimate (page 1 of 2)

\begin{tabular}{|c|c|c|c|c|c|c|}
\hline Release Volume (L) & 30,283 & 30,283 & 30,283 & 151,413 & 151,413 & 151,413 \\
\hline Analyte $(\mathrm{kg})$ & Case I & Case II & Case III & Case I & Case II & Case III \\
\hline $\mathrm{Ag}$ & $3.17 \mathrm{E}+00$ & $3.17 \mathrm{E}+00$ & $3.15 \mathrm{E}+00$ & $1.58 \mathrm{E}+01$ & $1.58 \mathrm{E}+01$ & $1.58 \mathrm{E}+01$ \\
\hline $\mathrm{Al}$ & $4.18 \mathrm{E}+02$ & $4.19 \mathrm{E}+02$ & $4.26 \mathrm{E}+02$ & $2.09 E+03$ & $2.10 \mathrm{E}+03$ & $2.13 E+03$ \\
\hline \multicolumn{7}{|l|}{ As } \\
\hline \multicolumn{7}{|l|}{$B$} \\
\hline $\mathrm{Ba}$ & $1.03 \mathrm{E}+01$ & $1.04 \mathrm{E}+01$ & $1.07 \mathrm{E}+01$ & $5.15 \mathrm{E}+01$ & $5.18 \mathrm{E}+01$ & $5.35 \mathrm{E}+01$ \\
\hline $\mathrm{Bi}$ & $1.15 \mathrm{E}+01$ & $1.15 \mathrm{E}+01$ & $1.15 \mathrm{E}+01$ & $5.76 \mathrm{E}+01$ & $5.76 \mathrm{E}+01$ & $5.73 \mathrm{E}+01$ \\
\hline $\mathrm{Ca}$ & $3.19 \mathrm{E}+01$ & $3.23 \mathrm{E}+01$ & $3.59 \mathrm{E}+01$ & $1.59 \mathrm{E}+02$ & $1.62 \mathrm{E}+02$ & $1.80 \mathrm{E}+02$ \\
\hline $\mathrm{Cd}$ & $5.06 \mathrm{E}-15$ & $2.94 \mathrm{E}-02$ & $2.60 \mathrm{E}-01$ & $2.53 \mathrm{E}-14$ & 1.47E -01 & $1.30 \mathrm{E}+00$ \\
\hline $\mathrm{Cl}$ & $9.46 \mathrm{E}+01$ & $9.45 \mathrm{E}+01$ & $9.42 \mathrm{E}+01$ & $4.73 \mathrm{E}+02$ & $4.73 \mathrm{E}+02$ & $4.71 \mathrm{E}+02$ \\
\hline TIC as $\mathrm{CO} 3$ & $4.12 \mathrm{E}+02$ & $4.12 \mathrm{E}+02$ & $4.11 \mathrm{E}+02$ & $2.06 \mathrm{E}+03$ & $2.06 \mathrm{E}+03$ & $2.05 \mathrm{E}+03$ \\
\hline $\mathrm{Cr}$ & $8.13 \mathrm{E}+01$ & $8.13 E+01$ & $8.14 \mathrm{E}+01$ & $4.07 \mathrm{E}+02$ & $4.07 \mathrm{E}+02$ & $4.07 \mathrm{E}+02$ \\
\hline \multicolumn{7}{|l|}{$\mathrm{Cu}$} \\
\hline$F$ & $5.26 \mathrm{E}+00$ & $5.26 E+00$ & $5.23 \mathrm{E}+00$ & $2.63 \mathrm{E}+01$ & $2.63 \mathrm{E}+01$ & $2.62 E+01$ \\
\hline $\mathrm{Fe}$ & $1.63 \mathrm{E}+02$ & $1.68 \mathrm{E}+02$ & $2.11 \mathrm{E}+02$ & $8.13 \mathrm{E}+02$ & $8.40 \mathrm{E}+02$ & $1.05 \mathrm{E}+03$ \\
\hline $\mathrm{Hg}$ & $2.29 \mathrm{E}-02$ & $2.29 \mathrm{E}-02$ & $2.28 \mathrm{E}-02$ & $1.14 \mathrm{E}-01$ & $1: 14 \mathrm{E}-01$ & $1.14 \mathrm{E}-01$ \\
\hline $\mathrm{K}$ & $5.20 \mathrm{E}+01$ & $5.20 E+01$ & $5.18 \mathrm{E}+01$ & $2.60 \mathrm{E}+02$ & $2.60 \mathrm{E}+02$ & $2.59 \mathrm{E}+02$ \\
\hline $\mathrm{La}$ & $1.96 \mathrm{E}+00$ & $1.95 \mathrm{E}+00$ & $1.95 \mathrm{E}+00$ & $9.78 \mathrm{E}+00$ & $9.77 \mathrm{E}+00$ & $9.73 \mathrm{E}+00$ \\
\hline $\mathrm{Mg}$ & $1.25 \mathrm{E}-14$ & $7.25 \mathrm{E}-02$ & $6.42 \mathrm{E}-01$ & $6.24 \mathrm{E}-14$ & $3.62 \mathrm{E}-01$ & $3.21 E+00$ \\
\hline $\mathrm{Mn}$ & $2.74 \mathrm{E}+01$ & $2.75 \mathrm{E}+01$ & $2.80 \mathrm{E}+01$ & $1.37 \mathrm{E}+02$ & $1.38 \mathrm{E}+02$ & $1.40 \mathrm{E}+02$ \\
\hline $\mathrm{Na}$ & $3.48 \mathrm{E} \div 03$ & $3.48 \mathrm{E}+03$ & $3.48 E+03$ & $1.74 E+04$ & $1.74 \mathrm{E}+04$ & $1.74 \mathrm{E}+04$ \\
\hline $\mathrm{Ni}$ & $5.34 \mathrm{E}+00$ & $5.61 \mathrm{E}+00$ & $7.67 \mathrm{E}+00$ & $2.67 \mathrm{E}+01$ & $2.80 \mathrm{E}+01$ & $3.84 \mathrm{E}+01$ \\
\hline $\mathrm{NO} 2$ & $1.58 \mathrm{E}+03$ & $1.58 \mathrm{E}+03$ & $1.57 \mathrm{E}+03$ & $7.90 \mathrm{E}+03$ & $7.90 \mathrm{E}+03$ & $7.87 \mathrm{E}+03$ \\
\hline $\mathrm{NO} 3$ & $2.35 \mathrm{E}+03$ & $2.35 \mathrm{E}+03$ & $2.35 \mathrm{E}+03$ & $1.18 \mathrm{E}+04$ & $1.18 \mathrm{E}+04$ & $1.18 \mathrm{E}+04$ \\
\hline $\mathrm{OH}$ & $1.84 \mathrm{E}+03$ & $1.85 \mathrm{E}+03$ & $1.88 \mathrm{E}+03$ & $9.21 \mathrm{E}+03$ & $9.23 \mathrm{E}+03$ & $9.38 \mathrm{E}+03$ \\
\hline $\mathrm{Pb}$ & $1.58 \mathrm{E}+01$ & $1.58 \mathrm{E}+01$ & $1.57 \mathrm{E}+01$ & $7.89 \mathrm{E}+01$ & $7.88 \mathrm{E}+01$ & $7.85 \mathrm{E}+01$ \\
\hline $\mathrm{P}$ as $\mathrm{PO} 4$ & $1.99 \mathrm{E}+02$ & $1.99 \mathrm{E}+02$ & $2.00 \mathrm{E}+02$ & $9.95 \mathrm{E}+02$ & $9.96 \mathrm{E}+02$ & $9.98 E+02$ \\
\hline$P$ & $3.31 \mathrm{E}+01$ & $3.31 E+01$ & $3.34 \mathrm{E}+01$ & $1.65 \mathrm{E}+02$ & $1.65 \mathrm{E}+02$ & $1.67 \mathrm{E}+02$ \\
\hline \multicolumn{7}{|l|}{$\mathrm{Se}$} \\
\hline $\mathrm{Si}$ as $\mathrm{SiO} 3$ & $5.47 \mathrm{E}+02$ & $5.51 \mathrm{E}+02$ & $5.80 \mathrm{E}+02$ & $2.74 \mathrm{E}+03$ & $2.75 E+03$ & $2.90 \mathrm{E}+03$ \\
\hline $\mathrm{S}$ as $\mathrm{SO} 4$ & $8.51 E+01$ & $8.53 \mathrm{E}+01$ & $8.70 \mathrm{E}+01$ & $4.25 \mathrm{E}+02$ & $4.26 \mathrm{E}+02$ & $4.35 \mathrm{E}+02$ \\
\hline$S$ & $1.05 \mathrm{E}+02$ & $1.05 \mathrm{E}+02$ & $1.05 \mathrm{E}+02$ & $5.26 \mathrm{E}+02$ & $5.26 \mathrm{E}+02$ & $5.27 \mathrm{E}+02$ \\
\hline $\mathrm{Sr}$ & $7.26 \mathrm{E}-01$ & 7.26E-01 & $7.23 \mathrm{E}-01$ & $3.63 \mathrm{E}+00$ & $3.63 E+00$ & $3.61 \mathrm{E}+00$ \\
\hline TOC & $1.81 \mathrm{E}+02$ & $1.81 \mathrm{E}+02$ & $1.83 \mathrm{E}+02$ & $9.06 \mathrm{E}+02$ & $9.07 \mathrm{E}+02$ & $9.14 \mathrm{E}+02$ \\
\hline Total U & $1.86 \mathrm{E}+02$ & $1.86 \mathrm{E}+02$ & $1.85 \mathrm{E}+02$ & $9.31 \mathrm{E}+02$ & $9.30 \mathrm{E}+02$ & $9.26 \mathrm{E}+02$ \\
\hline \multicolumn{7}{|l|}{$\mathrm{Zn}$} \\
\hline $\mathrm{Zr}$ & $9.95 \mathrm{E}-02$ & $9.94 \mathrm{E}-02$ & $9.90 \mathrm{E}-02$ & $4.97 \mathrm{E}-01$ & $4.97 \mathrm{E}-01$ & $4.95 \mathrm{E}-01$ \\
\hline
\end{tabular}


Table 19. Tank 241-AX-101 Retrieval Scenario Nonradiological

Constituent Leakage Estimate (page 2 of 2)

\begin{tabular}{|l|c|c|c|c|c|c|}
\hline Release Volume (L) & 30,283 & 30,283 & 30,283 & 151,413 & 151,413 & 151,413 \\
\hline Arialyte $(\mathrm{kg})$ & Case I & Case II & Case III & Case I & Case II & Case III \\
\hline EDTA & $1.18 \mathrm{E}+02$ & $1.18 \mathrm{E}+02$ & $1.19 \mathrm{E}+02$ & $5.90 \mathrm{E}+02$ & $5.91 \mathrm{E}+02$ & $5.96 \mathrm{E}+02$ \\
\hline $\mathrm{NH} 3$ & $1.13 \mathrm{E}+01$ & $1.13 \mathrm{E}+01$ & $1.13 \mathrm{E}+01$ & $5.65 \mathrm{E}+01$ & $5.66 \mathrm{E}+01$ & $5.67 \mathrm{E}+01$ \\
\hline $\mathrm{Cr}+6$ & & & & & & \\
\hline $\mathrm{CN}$ & & & & & & \\
\hline $\mathrm{H} 2 \mathrm{O}$ & $7.11 \mathrm{E}+03$ & $7.13 \mathrm{E}+03$ & $7.23 \mathrm{E}+03$ & $3.56 \mathrm{E}+04$ & $3.56 \mathrm{E}+04$ & $3.61 \mathrm{E}+04$ \\
\hline Retrieval water & $1.76 \mathrm{E}+04$ & $1.76 \mathrm{E}+04$ & $1.76 \mathrm{E}+04$ & $8.79 \mathrm{E}+04$ & $8.79 \mathrm{E}+04$ & $8.80 \mathrm{E}+04$ \\
\hline Total (kg) & $3.66 \mathrm{E}+04$ & $3.67 \mathrm{E}+04$ & $3.69 \mathrm{E}+04$ & $1.83 \mathrm{E}+05$ & $1.83 \mathrm{E}+05$ & $1.84 \mathrm{E}+05$ \\
\hline
\end{tabular}


Table 20. Tank 241-AX-101 Retrieval Scenario Nonradiological Constituent Leakage Estimate (page 1 of 2)

\begin{tabular}{|c|c|c|c|c|c|c|}
\hline Release Volume $(\mathrm{L})$ & 30,283 & 30,283 & 30,283 & 151,413 & 151,413 & 151,413 \\
\hline Analyte (Ci) & Case I & Case II & Case III & Case I & Case II & Case III \\
\hline Decay Date & $12 / 31 / 99$ & $12 / 31 / 99$ & $12 / 31 / 99$ & $12 / 31 / 99$ & $12 / 31 / 99$ & $12 / 31 / 99$ \\
\hline $3 \mathrm{H}$ & $7.48 \mathrm{E}-17$ & $4.34 \mathrm{E}-04$ & 3.84E-03 & $3.74 \mathrm{E}-16$ & $2.17 \mathrm{E}-03$ & $1.92 \mathrm{E}-02$ \\
\hline $14 \mathrm{C}$ & $3.53 \mathrm{E}-02$ & $3.53 \mathrm{E}-02$ & $3.54 \mathrm{E}-02$ & $1.76 \mathrm{E}-01$ & $1.76 \mathrm{E}-01$ & $1.77 \mathrm{E}-01$ \\
\hline $59 \mathrm{Ni}$ & $5.50 \mathrm{E}-16$ & $3.19 \mathrm{E}-03$ & $2.82 \mathrm{E}-02$ & $2.75 \mathrm{E}-15$ & $1.60 \mathrm{E}=02$ & $1.41 \mathrm{E}-01$ \\
\hline $60 \mathrm{Co}$ & $1.44 \mathrm{E}+00$ & $1.44 \mathrm{E}+00$ & $1.43 \mathrm{E}+00$ & $7.19 \mathrm{E}+00$ & $7.19 \mathrm{E}+00$ & $7.16 \mathrm{E}+00$ \\
\hline $63 \mathrm{Ni}$ & $5.41 \mathrm{E}-14$ & $3.14 \mathrm{E}-01$ & $2.78 \mathrm{E}+00$ & $2.70 \mathrm{E}-13$ & $1.57 \mathrm{E}+00$ & $1.39 \mathrm{E}+01$ \\
\hline $79 \mathrm{Se}$ & $3.06 \mathrm{E}-16$ & $1.78 \mathrm{E}-03$ & $1.57 \mathrm{E}-02$ & $1.53 \mathrm{E}-15$ & $8.89 \mathrm{E}-03$ & $7.87 \mathrm{E}-02$ \\
\hline $90 \mathrm{Sr}$ & $4.47 \mathrm{E}+03$ & $4.52 \mathrm{E}+03$ & $4.89 \mathrm{E}+03$ & $2.24 \mathrm{E}+04$ & $2.26 E+04$ & $2.45 E+04$ \\
\hline $90 Y$ & $4.47 \mathrm{E}+03$ & $4.52 \mathrm{E}+03$ & $4.89 \mathrm{E}+03$ & $2.24 \mathrm{E}+04$ & $2.26 \mathrm{E}+04$ & $2.45 \mathrm{E}+04$ \\
\hline $93 \mathrm{mNb}$ & $1.14 \overline{\mathrm{E}}-15$ & $6.59 \mathrm{E}-03$ & $5.83 \mathrm{E}-02$ & $5.68 \mathrm{E}-15$ & $3.30 \mathrm{E}-02$ & 2.92E-01 \\
\hline $93 \mathrm{Zr}$ & 1.32E-15 & $7.68 \mathrm{E}-03$ & $6.80 \mathrm{E}-02$ & $6.62 \mathrm{E}-15$ & $3.84 \mathrm{E}-02$ & $3.40 \mathrm{E}-01$ \\
\hline $99 \mathrm{Tc}$ & $2.06 \mathrm{E}+00$ & $2.06 \mathrm{E}+00$ & $2.05 \mathrm{E}+00$ & $1.03 \mathrm{E}+01$ & $1.03 E+01$ & $1.03 E+01$ \\
\hline 106Ru & $2.37 \mathrm{E}-18$ & $1.38 \mathrm{E}-05$ & $1.22 \mathrm{E}-04$ & $1.18 \mathrm{E}-17$ & $6.88 \mathrm{E}-05$ & $6.09 \mathrm{E}-04$ \\
\hline $113 \mathrm{mCd}$ & $2.82 \mathrm{E}-15$ & $1.64 \mathrm{E}-02$ & $1.45 \mathrm{E}-01$ & $1.41 \mathrm{E}-14$ & $8.19 \mathrm{E}-02$ & $7.25 \mathrm{E}-01$ \\
\hline $125 \mathrm{Sb}$ & $7.29 \mathrm{E}-17$ & $4.23 \mathrm{E}-04$ & $3.75 \mathrm{E}-03$ & $3.64 \mathrm{E}-16$ & $2.12 \mathrm{E}-03$ & $1.87 \mathrm{E}-02$ \\
\hline $126 \mathrm{Sn}$ & $4.92 \mathrm{E}-16$ & $2.86 \mathrm{E}-03$ & $2.53 \mathrm{E}-02$ & $2.46 \mathrm{E}-15$ & $1.43 \mathrm{E}-02$ & $1.26 \mathrm{E}-01$ \\
\hline $129 \mathrm{I}$ & $4.60 \mathrm{E}-04$ & $4.61 \mathrm{E}-04$ & $4.62 \mathrm{E}-04$ & $2.30 \mathrm{E}-03$ & $2.30 \mathrm{E}-03$ & $2.31 \mathrm{E}-03$ \\
\hline $134 \mathrm{Cs}$ & $8.79 \mathrm{E}-18$ & $5.10 \mathrm{E}-05$ & $4.52 \mathrm{E}-04$ & $4.40 \mathrm{E}-17$ & $2.55 \mathrm{E}-04$ & $2.26 \mathrm{E}-03$ \\
\hline \multicolumn{7}{|l|}{$135 \mathrm{Cs}$} \\
\hline $137 \mathrm{Cs}$ & $2.36 \mathrm{E}+03$ & $2.36 \mathrm{E}+03$ & $2.36 \mathrm{E}+03$ & $1.18 \mathrm{E}+04$ & $1.18 \mathrm{E}+04$ & $1.18 \mathrm{E}+04$ \\
\hline $137 \mathrm{mBa}$ & $2.24 \mathrm{E}+03$ & $2.24 \mathrm{E}+03$ & $2.23 \mathrm{E}+03$ & $1.12 \mathrm{E}+04$ & $1.12 \mathrm{E}+04$ & $1.12 \mathrm{E}+04$ \\
\hline $151 \mathrm{Sm}$ & $1.15 \mathrm{E}-12$ & $6.65 \mathrm{E}+00$ & $5.89 \mathrm{E}+01$ & $5.73 \mathrm{E}-12$ & $3.32 \mathrm{E}+01$ & $2.94 E+02$ \\
\hline 152Eu & $2.87 \mathrm{E}-16$ & $1.66 \mathrm{E}-03$ & $1.47 \mathrm{E}-02$ & $1.43 \mathrm{E}-15$ & $8.32 \mathrm{E}-03$ & $7.36 \mathrm{E}-02$ \\
\hline $154 \mathrm{Eu}$ & $6.73 \mathrm{E}-15$ & $3.91 \mathrm{E}-02$ & $3.46 \mathrm{E}-01$ & $3.37 \mathrm{E}-14$ & $1.95 \mathrm{E}-01$ & $1.73 E+00$ \\
\hline 155Eu & $1.76 \mathrm{E}-14$ & $1.02 \mathrm{E}-01$ & $9.02 \mathrm{E}-01$ & $8.78 \mathrm{E}-14$ & $5.10 \mathrm{E}-01$ & $4.51 \mathrm{E}+00$ \\
\hline $226 \mathrm{Ra}$ & $3.69 \mathrm{E}-20$ & $2.14 \mathrm{E}-07$ & $1.90 \mathrm{E}-06$ & $1.85 \mathrm{E}-19$ & $1.07 \mathrm{E}-06$ & $9.49 \mathrm{E}-06$ \\
\hline $227 \mathrm{AC}$ & $1.91 \mathrm{E}-19$ & $1.11 E-06$ & 9.82E-06 & $9.55 \mathrm{E}-19$ & $5.54 \mathrm{E}-06$ & $4.91 \mathrm{E}-05$ \\
\hline $228 \mathrm{Ra}$ & $1.68 \mathrm{E}-25$ & $9.73 \mathrm{E}-13$ & $8.61 \mathrm{E}-12$ & $8.38 \mathrm{E}-25$ & $4.86 \mathrm{E}-12$ & $4.31 \mathrm{E}-11$ \\
\hline $229 \mathrm{Th}$ & $2.78 \mathrm{E}-23$ & $1.62 \mathrm{E}-10$ & $1.43 \mathrm{E}-09$ & $1.39 \mathrm{E}-22$ & $8.08 \mathrm{E}-10$ & $7.15 \mathrm{E}-09$ \\
\hline $231 \mathrm{~Pa}$ & $2.86 \mathrm{E}-19$ & $1.66 \mathrm{E}-06$ & $1.47 \mathrm{E}-05$ & $1.43 \mathrm{E}-18$ & $8.29 \mathrm{E}-06$ & $7.34 \mathrm{E}-05$ \\
\hline $232 \mathrm{Th}$ & $2.26 \mathrm{E}-27$ & $1.31 \mathrm{E}-14$ & $1.16 \mathrm{E}-13$ & $1.13 \mathrm{E}-26$ & $6.56 \mathrm{E}-14$ & $5.81 \mathrm{E}-13$ \\
\hline $232 \mathrm{U}$ & 7.39E-24 & $4.29 \mathrm{E}-11$ & $3.80 \mathrm{E}-10$ & $3.69 \mathrm{E}-23$ & $2.14 \mathrm{E}-10$ & 1.90E-09 \\
\hline $233 \mathrm{U}$ & $1.04 \mathrm{E}-25$ & $6.01 \mathrm{E}-13$ & $5.33 \mathrm{E}-12$ & $5.18 \mathrm{E}-25$ & $3.01 \mathrm{E}-12$ & $2.66 \mathrm{E}-11$ \\
\hline $234 \mathrm{U}$ & $3.09 \mathrm{E}-20$ & $1.79 \mathrm{E}-07$ & $1.59 \mathrm{E}-06$ & $1.55 \mathrm{E}-19$ & $8.97 \mathrm{E}-07$ & $7.94 \mathrm{E}-06$ \\
\hline $235 \mathrm{U}$ & $1.21 \mathrm{E}-21$ & $7.01 \mathrm{E}-09$ & $6.21 \mathrm{E}-08$ & $6.04 \mathrm{E}-21$ & $3.50 \mathrm{E}-08$ & $3.10 \mathrm{E}-07$ \\
\hline $236 \mathrm{U}$ & $2.04 \mathrm{E}-21$ & $1.18 \mathrm{E}-08$ & $1.05 \mathrm{E}-07$ & $1.02 \mathrm{E}-20$ & $5.91 \mathrm{E}-08$ & $5.23 \mathrm{E}-07$ \\
\hline
\end{tabular}


Table 20. Tank 241-AX-101 Retrieval Scenario Nonradiological Constituent Leakage Estimate (page 2 of 2)

\begin{tabular}{|l|c|c|c|c|c|c|}
\hline Release Volume (L) & 30,283 & 30,283 & 30,283 & 151,413 & 151,413 & 151,413 \\
\hline Analyte (Ci) & Case I & Case II & Case II & Case I & Case II & Case II \\
\hline Decay Date & $12 / 31 / 99$ & $12 / 31 / 99$ & $12 / 31 / 99$ & $12 / 31 / 99$ & $12 / 31 / 99$ & $12 / 31 / 99$ \\
\hline $237 \mathrm{~Np}$ & $1.31 \mathrm{E}-19$ & $7.58 \mathrm{E}-07$ & $6.71 \mathrm{E}-06$ & $6.53 \mathrm{E}-19$ & $3.79 \mathrm{E}-06$ & $3.36 \mathrm{E}-05$ \\
\hline $238 \mathrm{Pu}$ & $4.30 \mathrm{E}-16$ & $2.49 \mathrm{E}-03$ & $2.21 \mathrm{E}-02$ & $2.15 \mathrm{E}-15$ & $1.25 \mathrm{E}-02$ & $1.10 \mathrm{E}-01$ \\
\hline $238 \mathrm{U}$ & $2.48 \mathrm{E}-20$ & $1.44 \mathrm{E}-07$ & $1.27 \mathrm{E}-06$ & $1.24 \mathrm{E}-19$ & $7.19 \mathrm{E}-07$ & $6.37 \mathrm{E}-06$ \\
\hline $239 \mathrm{Pu}$ & $1.15 \mathrm{E}-14$ & $6.69 \mathrm{E}-02$ & $5.93 \mathrm{E}-01$ & $5.76 \mathrm{E}-14$ & $3.35 \mathrm{E}-01$ & $2.96 \mathrm{E}+00$ \\
\hline $240 \mathrm{Pu}$ & $3.04 \mathrm{E}-14$ & $1.77 \mathrm{E}-01$ & $1.56 \mathrm{E}+00$ & $1.52 \mathrm{E}-13$ & $8.84 \mathrm{E}-01$ & $7.82 \mathrm{E}+00$ \\
\hline $239 / 240 \mathrm{Pu}$ & $2.02 \mathrm{E}+01$ & $2.05 \mathrm{E}+01$ & $2.23 \mathrm{E}+01$ & $1.01 \mathrm{E}+02$ & $1.02 \mathrm{E}+02$ & $1.11 \mathrm{E}+02$ \\
\hline $241 \mathrm{Am}$ & $1.24 \mathrm{E}+01$ & $1.24 \mathrm{E}+01$ & $1.30 \mathrm{E}+01$ & $6.19 \mathrm{E}+01$ & $6.22 \mathrm{E}+01$ & $6.49 \mathrm{E}+01$ \\
\hline $241 \mathrm{Pu}$ & $3.04 \mathrm{E}-14$ & $1.77 \mathrm{E}-01$ & $1.56 \mathrm{E}+00$ & $1.52 \mathrm{E}-13$ & $8.84 \mathrm{E}-01$ & $7.82 \mathrm{E}+00$ \\
\hline $242 \mathrm{Cm}$ & $1.09 \mathrm{E}-17$ & $6.33 \mathrm{E}-05$ & $5.60 \mathrm{E}-04$ & $5.45 \mathrm{E}-17$ & $3.16 \mathrm{E}-04$ & $2.80 \mathrm{E}-03$ \\
\hline $242 \mathrm{mAm}$ & - & & & & & \\
\hline $242 \mathrm{Pu}$ & $1.79 \mathrm{E}-19$ & $1.04 \mathrm{E}-06$ & $9.21 \mathrm{E}-06$ & $8.97 \mathrm{E}-19$ & $5.20 \mathrm{E}-06$ & $4.61 \mathrm{E}-05$ \\
\hline $243 \mathrm{Am}$ & $6.80 \mathrm{E}-19$ & $3.95 \mathrm{E}-06$ & $3.50 \mathrm{E}-05$ & $3.40 \mathrm{E}-18$ & $1.97 \mathrm{E}-05$ & $1.75 \mathrm{E}-04$ \\
\hline $243 \mathrm{Cm}$ & $9.82 \mathrm{E}-19$ & $5.70 \mathrm{E}-06$ & $5.05 \mathrm{E}-05$ & $4.91 \mathrm{E}-18$ & $2.85 \mathrm{E}-05$ & $2.52 \mathrm{E}-04$ \\
\hline $244 \mathrm{Cm}$ & $3.98 \mathrm{E}-17$ & $2.31 \mathrm{E}-04$ & $2.05 \mathrm{E}-03$ & $1.99 \mathrm{E}-16$ & $1.16 \mathrm{E}-03$ & $1.02 \mathrm{E}-02$ \\
\hline Total & $1.36 \mathrm{E}+04$ & $1.37 \mathrm{E}+04$ & $1.45 \mathrm{E}+04$ & $6.78 \mathrm{E}+04$ & $6.83 \mathrm{E}+04$ & $7.23 \mathrm{E}+04$ \\
\hline
\end{tabular}




\section{APPENDIX C \\ BEST-BASIS INVENTORY, RETRIEVAL INVENTORY, AND LEAKAGE INVENTORY ESTIMATES FOR RETRIEVAL OF WASTE FROM SINGLE-SHELL TANK 241-AX-102}

D. W. Hendrickson, P.E. S. L. Lambert, Ph.D. SGN Eurisys Services Corporation Richländ; Washington 
HNF-SD-HTI-TI-001, REV. 0

SESC-EN-RPT-002, Rev. 1

(formally known as)

CONTENTS

1.0 CHEMICAL INFORMATION SOURCES $\ldots \ldots \ldots \ldots \ldots \ldots \ldots \ldots \ldots \ldots, 1$

2.0 CHEMICAL/RADIONUCLIDE INVENTORY ESTIMATES BEFORE

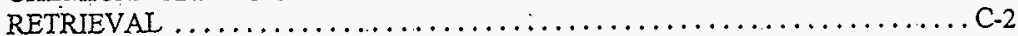

2.1 CONTRIBUTING WASTE TYPES $\ldots \ldots \ldots \ldots \ldots \ldots \ldots \ldots \ldots \ldots, \mathrm{C}-3$

2.1 .1 Sludge Layer $\ldots \ldots \ldots \ldots \ldots \ldots \ldots \ldots \ldots \ldots \ldots \ldots \ldots, \mathrm{C}-3$

2.1 .2 Saltcake Layer $\ldots \ldots \ldots \ldots \ldots \ldots \ldots \ldots \ldots \ldots \ldots \ldots, \mathrm{C}-4$

3.0 CHEMICAL/RADIONUCLDE INVENTORY ESTIMATES AFTER

RETRIEVAL .................................

3.1 CHEMICAL AND RADIONUCLIDE NNVENTORIES BASED ON 90

PERCENT RETRIEVAL $\ldots \ldots \ldots \ldots \ldots \ldots \ldots \ldots \ldots \ldots \ldots \ldots \ldots \ldots$

4.0 BEST-BASIS LEAKAGE INVENTORY ESTIMATES FOR RETRIEVAL OF SINGLE-SHELL TANK 241 AX-102 $\ldots \ldots \ldots \ldots \ldots \ldots \ldots \ldots \ldots \ldots \ldots$, C-5

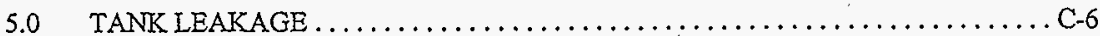

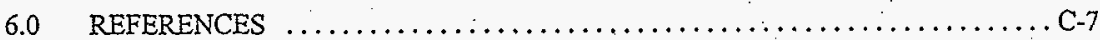

\section{TABLES:}

1. Volume Data (in kgal/kL) for Tank 241-AX-102 Sludge and Saltcake $\ldots \ldots \ldots \ldots$ CT-1

2. Best-Basis Nonradiological Inventory Before Retrieval of Waste From Single-Shell

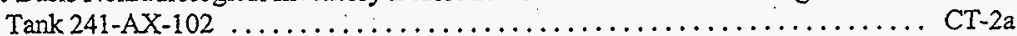

3. Best-Basis Radiological Inventory Before Retrieval of Waste From Single-Shell

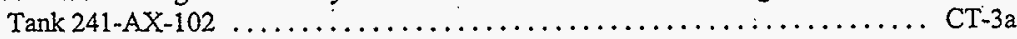

4. Comparison of 1988 Supernatant Liquid Sample from Tank 241-AX-102 with

Supernatant Liquid Samples from Concentrated Complexed Waste

Tanks 241-AN-102 and 241-AN-107

CT-4

5. Comparison of Supernate Mixing Model, Samples from Tanks 241-AN-102 and

241-AN-107 and Best-Basis Saltcake Composition Estimates for the Saltcake

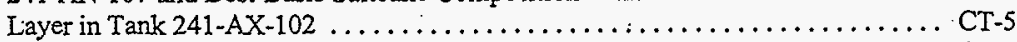

6. Retrieval Scenario Summary of Residual Waste and Fractional Removal .......... CT-6

7. Tank 241-AX-102 Nonradiological Waste Residual Inventory Following Retrieval .. CT-7a

8. Tank 241-AX-102 Radiological Waste Residual Inventory Following Retrieval ..... CT-8a

- Rotrinval Cromarin Prnturt Solution Nonradiological Analyte Concentrations . . . . . . CT-9a

10. Retrieval Scenario Product Solution Radiological Analyte Concentrations ....... $\cup_{1-1 \text { va }}$

11. Tank 241-AX-102 Retrieval Scenario Nonradiological Constituent Leakage

Estimate ...................................... CT-11a

12. Tank 241-AX-102 Retrieval Scenario Radiological Constituent Leakage Estimate . CT-12a

13. 1988 Supernate Composition and Inventories of Chemicals and Radionuclides That

Potentially Leaked from Tank 241-AX-102

CT-13 
The purpose of this study is to provide the best-basis estimate of the chemical and radiological waste inventory after retrieval of waste from the AX farm. As part of this effort, an evaluation of available information for Tank 241-AX-102 was performed and a best-basis inventory was established for three different retrieval scenarios. The first scenario is based on either retrieving at least 90 percent of the waste to a residual volume of $101.94 \mathrm{~m}^{3}\left(3,600 \mathrm{ft}^{3}\right)$ of waste, or the current volume if this volume is less than $101.94 \mathrm{~m}^{3}$ (3,600 $\mathrm{ft}^{3}$. The second scenario assumes 99 percent retrieval of waste from the tank to meet the Hanford Federal Facility Agreement and Consent Order (Ecology et al. 1990) (Tri-Party Agreement) milestone of $101.9 \mathrm{~m}^{3}\left(360 \mathrm{ft}^{3}\right)$ of residual waste, while the third scenario assumes 99.9 percent retrieval to a residual volume of $1.02 \mathrm{~m}^{3}\left(36 \mathrm{ft}^{3}\right)$ of waste. This study, detailed in the following sections, is based on the methodology that was established by the standard inventory task.

\subsection{CHEMICAL INFORMATION SOURCES}

Chemical and radionuclide inventory estimates are generally derived from one of three sources of information: (1) sample analysis and sample derived inventory estimates, (2) component inventories predicted by the Hanford Defined Waste (HDW) model based on process knowledge and historical tank transfer information, or (3) a tank-specific process estimate based on process flowsheets, reactor fuel data, essential materials records, or comparable sludge layers and sample information from other tanks.

A total of seven sampling events have occurred for Tank 241-AX-102. One sludge sample was taken in 1974, as the tank was being prepared for sluicing. The tank then contained 189;000 L. ( $50 \mathrm{kgal})$ of sludge derived primarily from B Plant waste. The sample was analyzed for percent water, density, radionuclides, and a few metals. After sluicing (1976/1977), the tank contained a heel of approximately $26,000 \mathrm{~L}$ ( $7 \mathrm{kgal})$ of sludge. Six samples of the remaining sludge were analyzed for radionuclide content only.

After sluicing was completed, the tank was used as both a feed and slurry storage tank for the 242-A evaporator-crystallizer (1977 to 1980). The evaporator was processing complexed waste during that time. Analytical results for two liquid grab samples taken in early 1980 show the composition of the evaporator feed solution in the tank at that time. These results provide no quantitative estimates of the solids deposited on top of the sludge heel, but they do indicate the type of waste that was being stored in the tank.

In 1988, the tank was declared a leaker, and a liquid grab sample was taken to establish the composition of the liquid to be pumped out of the tank by salt well pumping. This sample contained no solids, but analysis of the liquid firmly identifies the waste as concentrated complexed (CC) waste (waste having a total organic carbon concentration over $10 \mathrm{~g} / \mathrm{L}$ at the aluminate phase boundary). The composition of the solids deposited during the evaporator operations (approximately 98,000 L) can be assumed to be similar in composition to the solids deposited by CC wastes in double-shell Tanks 241-AN-107 and 241-AN-102, where the solids have been analyzed (Herting 1994a and 1996). The projected composition of these solids also generally matches, except for some of the minor components, the composition profile for SMMA1 saltcake from the 242-A evaporator, based on two cores and one auger sample from 
Tank 241-A-102 and two core samples from Tank 241-A-103 (best-basis standard inventory for Tank 241-AX-103).

Two auger samples were also taken from the surface of Tank 241-AX-102 in February 1995, to support the safety assessment of the tank. Limited analyses were obtained from these samples.

\subsection{CHEMICAL/RADIONUCLIDE INVENTORY ESTIMATES BEFORE RETRIEVAL}

Hanlon (1996) estimates that Tank 241-AX-102 contains $26,500 \mathrm{~L}$ ( $7 \mathrm{kgal}$ ) of sludge, 110,000 L ( $29 \mathrm{kgal})$ of saltcake, and $11,000 \mathrm{~L}$ ( $3 \mathrm{kgal}$ ) of supernatant liquid. These values are based on the surface level measurements and tank photographs taken at the time the tank was pumped in 1988. More recent photographs show that there is no supernatant liquid left in the tank.

A 1993 report on waste level discrepancies (Swaney 1993) indicate that the surface reading used for the Hanlon volume estimates was probably high by $5.5 \mathrm{~cm}(2.18 \mathrm{in}$.) because the manual tape appeared to contact a small pipe protruding from the waste. No adjustment was made to the Hanlon inventory.

Current waste level readings are fairly consistent at $24 \mathrm{~cm}(9.5 \mathrm{in}$.). The drop in the surface level from $30.5 \mathrm{~cm}$ (12.02 in.) in 1993 to $24 \mathrm{~cm}$ (9.5 in.) in 1997 is probably due to evaporation of water, which is consistent with the photographic evidence of the disappearance of supernatant liquid. The bulk of the analytical data applies to the composition of the waste before the recent drying trend, so the earlier surface level reading (Swaney 1993) was used for the best-basis inventory evaluation.

According to the HDW model, Tank 241-AX-102 contains $23,000 \mathrm{~L}$ ( $6 \mathrm{kgal}$ ) of sludge, $125,000 \mathrm{~L}$ ( $33 \mathrm{kgal})$ of saltcake; and no supernatant liquid.

Table 1 shows a summary of the volume data available, and the data chosen for the best-basis inventory evaluation. The best-basis inventory will be estimated from $26.5 \mathrm{~kL}\left(934 \mathrm{ft}^{3}\right)$ of sludge and $98.4 \mathrm{~kL}\left(3,470 \mathrm{ft}^{3}\right)$ of saltcake.

Tables 2 and 3 provide the best-basis inventory estimates for the combined sludge and saltcake layers in Tank $241-\mathrm{AX}-102$ for nonradiological and radiological constituents, respectively. These estimates incorporated HDW model (Agnew et al. 1997a) estimates where sample data does not address the waste composition. The radionuclide inventory values were derived for 46 key radionuclides (Kupfer et al. 1997). Waste sample analyses have often only reported ${ }^{90} \mathrm{Sr}$, ${ }^{137} \mathrm{Cs}$, ${ }^{239 / 240} \mathrm{Pu}$, and total uranium (or total beta and total alpha), while other key radionuclides, such as ${ }^{60} \mathrm{Co},{ }^{99} \mathrm{Tc},{ }^{129} \mathrm{I},{ }^{154} \mathrm{Eu},{ }^{155} \mathrm{Eu}$, and ${ }^{241} \mathrm{Am}$, etc., have been infrequently reported. For this reason it was necessary to derive most of the $46 \mathrm{key}$ radionuclides by computer models. These models estimate radionuclide activity in batches of reactor fuel, account for the split of radionuclides to various separations plant waste streams, and track their movement with tank waste transactions (Kupfer et al. 1997 and Watrous and Wootan 1997) Model-generated values for radionuclides in any of the 177 tanks are reported in the HDW Rev. 4 model results 
(Agnew et al. 1997a). No attempt has been made to ratio or normalize model results for all 46 radionuclides when values for measured radionuclides disagree with the model. For a discussion of typical error between model-derived values and sample derived values see Kupfer et al. (1997).

\subsection{CONTRIBUTING WASTE TYPES}

There is general agreement among various sources that Tank 241-AX-102 contains two layers of waste, the bottom layer referred to as sludge and the top layer as saltcake. Each layer is discussed below.

\subsection{Sludge Layè}

The HDW model indicates that the sludge layer is composed of $3.8: \mathrm{kL}$ (1 kgal) of PUREX low-level waste sludge (PL) and $19 \mathrm{~kL}(5 \mathrm{kgal})$ of $B$ Plant waste (B) from strontium extraction operations.

One grab sample of sludge was taken in 1974 in preparation for sluicing the sludge from the tank Six more samples were taken after the sluicing was completed, but analyses were limited to a few radionuclides. The ${ }^{137} \mathrm{Cs}$ and ${ }^{90} \mathrm{Sr}$ activities reported for the pre-sluicing sample were within the range of activities reported in the six post-sluicing samples, so the chemical analyses from the pre-sluicing sample are believed to be representative of the heel left after sluicing. Tisusentin

Tables 1 and 2 incorporate the composition as determined by adjusting the HDW model estimates to account for the apparent bias in percent water. The pre-sluicing sludge sample had a higher density andlower percent water than the HDW estimate. If the differences are assumed to have been caused by evaporation of water from the sludge, then both differences:(density and percent water) are consistènt.

semetisits

The HDW concentrations were adjusted by algebraically calculating how much the concentrations would have changed when the water evaporated: The calculation is as follows, using sodium as an example:

Assume $100 \mathrm{~g}$ of sludge at $63.7 \% \mathrm{H}_{2} \mathrm{O}$ and $4.78 \% \mathrm{Na}$ before evaporation.

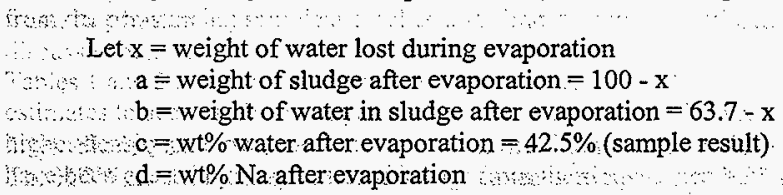


Concentrations derived from the adjusted HDW model predictions are in general agreement with sampling data, but there are some noteworthy exceptions. Manganese was predicted to be absent in the sludge, but analyses show a significant concentration from the PUREX organic wash (OWW2) waste added to this tank. The HDW model predicted less ${ }^{137} \mathrm{Cs}$ and more ${ }^{90} \mathrm{Sr}$ than found in samples. The concentration of uranium in samples varied over a wide range, from $0.13 \mu \mathrm{g} / \mathrm{g}\left(1.7 \times 10^{-6} \mathrm{lb} / \mathrm{gal}\right)$ to $990 \mu \mathrm{g} / \mathrm{g}(0.013 \mathrm{lb} / \mathrm{gal})$, but all of the values were far less than the HDW model prediction.

\subsubsection{Saltcake Layer}

The saltcake layer of waste in the tank was deposited during the years, 1977 to 1980 , when the tank was being used in conjunction with 242-A Evaporator-Crystallizer Operations. The HDW model uses the Supernate Mixing Model (SMM) subroutine to predict an inventory of $125 \mathrm{~kL}$ $(33 \mathrm{kgal})$ : of saltcake.

In 1988; the tank was declared a leaker and a liquid grab sample was taken to establish the composition of the liquid to be pumped out of the tank by salt well pumping. This sample contained no solids, but analysis of the liquid firmly identifies the waste as $\mathrm{CC}$ waste (Table 4). Specific "markers" for $\mathrm{CC}$ waste include the concentrations of carbonate, total organic carbon (TOC), ${ }^{241} \mathrm{Am}$; and ${ }^{90} \mathrm{Sr}$, all of which are much higher in $\mathrm{CC}$ waste than in other types of liquid Hanford waste.

The composition of the solids deposited during evaporator operations (approximately $98.4 \mathrm{~kL}$ ) can be:assumed to be similar in composition to the solids deposited by $\mathrm{CC}$ wastes in double-shell Tanks 241-AN-102 and 241-AN-107, where the solids have been analyzed. The projected composition of these solids also generally matches, except for some of the minor components, the composition profile for SMMA1 saltcake from the 242-A evaporator, based on two cores and one auger sample from Tank 241-A-102 and two core samples from Tank 241-A-103 (best-basis standard inventory for Tank 241-AX-103). Table 5 shows a comparison of the compositions of the saltcake as predicted by the SMM subroutine and as determined by analysis in Tanks 241-AN-102 and 241-AN-107.

Agreement between SMM predictions and analytical data is generally good, but the SMM subroutine appears to have a tendency to underestimate the concentrations of sparingly soluble components $(\mathrm{Fe}, \mathrm{Pb}, \mathrm{Ni}, \mathrm{Mn})$ and overestimate concentrations of very soluble components $\left(\mathrm{NO}_{3}\right.$, $\left.\mathrm{NO}_{2}, \mathrm{CO}_{3}\right)$ :

Two atiger samples were taken from the surface of the 241-AX-102 waste in February 1995, to support the safety assessment of the tank. Limited analyses were obtained from these samples (Section 4). The moisture content of the auger samples (30.5 percent) was less than the SMM prediction: (39.3 percent) and the 241-AN tank samples (average 42.3 percent). The lower moisture content is consistent with the drying trend in the tank that has caused the surface level to drop from $30.5 \mathrm{~cm}$ (12 in) in 1988 to the current $24.1 \mathrm{~cm}(9.5 \mathrm{in})$.

The nitrate concentration in the auger samples $(172,000 \mu \mathrm{g} / \mathrm{g})$ is higher than in 241-AN samples and slightly lower than in the SMM prediction. The nitrite concentration in the auger samples $(40,700 \mu \mathrm{g} / \mathrm{g})$ is slightly lower than sample average, but well below the SMM estimate. The TOC value for the auger samples $(56,550 \mu \mathrm{g} / \mathrm{g})$ is approximately twice the value from the 
241-AN samples and five times the SMM prediction. The analytical values for the auger samples were not used in developing the best-estimate inventory because the inverttory was based on the analytical data that represented the sludge at the time when the wastelevel in the tank was $30.5 \mathrm{~cm}$ (12 in.), i.e., before the sludge dried out due to evaporation of water.

\subsection{CHEMICAL/RADIONUCLIDE INVENTORY ESTIMATES AFTER RETRUEVAL}

As part of this study, a best basis inventory was established for three different retrieval scenarios. The first scenario is based on retrieving waste to minimum of either the existing waste volume or a residual waste volume of $101.94 \mathrm{~m}^{3}\left(3600 \mathrm{ft}^{3}\right)$. The second scenario assumes retrieval to a residual waste volume of $10.2 \mathrm{~m}^{3}\left(360 \mathrm{ft}^{3}\right)$ which corresponds to the assumed 99 percent retrieval of waste to meet the Tri-Party Agreement (Ecology et al. 1990). The third scenario assumes retrieval to a residual waste volume of $1.02 \mathrm{~m}^{3}\left(36 \mathrm{ft}^{3}\right)$. The first and third scenarios represent the retrieval of all tank wastes to 90 percent and 99.9 percent respectively.

\subsection{CHEMICAL AND RADIONUCLIDE INVENTORUES BASED ON 90 PERCENT RETRIEVAL}

The first retrieval scenario assumes that 90 percent of the waste will be retrieved to a residual volume of $101.94 \mathrm{~m}^{3}\left(3,600 \mathrm{ft}^{3}\right)$. Since the current sludge inventory is estimated to be $26.45 \mathrm{~m}^{3}$ $\left(934 \mathrm{ft}^{3}\right)$ and overlying saltcake inventory $98.3 \mathrm{~m}^{3}\left(3,470 \mathrm{ft}^{3}\right)$, about 23.2 percent of the saltcake would have to be removed to meet this inventory target. Table 6 provides a summary of the chemical and radionuclide composition and tank inventory estimates based on the volume and density of the sludge layer ( $26.5 \mathrm{~kL}$ and $1.57 \mathrm{~kg} / \mathrm{L}$, respectively), and volume and density of the residual saltcake layer ( $75.6 \mathrm{~kL}$ and $1.5 \mathrm{~kg} / \mathrm{L}$, respectively). These values were derived from the best-basis standard inventory estimates for this tank.

Table 6 contains a summary matrix of resultant saltcake and sludge volumes, and their fractional removal, following retrieval according to the three scenarios of 90 percent, 99 percent, and 99.9 percent retrieval.

Following retrieval according to the three scenarios presented in Table 6, residual tank waste inventory has been evaluated and is presented in Tables 7 and 8 for chemical and radiological constituents, respectively.

\subsection{BEST-BASIS LEAKAGE INVENTORY ESTIMATES FOR RETRIEVAL OF SINGLE-SHELL TANK 241-AX-102}

Retrieval scenarios described in Section 3.0 provide residual inventories following fractional removal of any saltcake and sludges contained within Tank 241-AX-101. This section assumes 
two different leakage conditions for each retrieval scenario. The first leakage condition assumes up to $30.2 \mathrm{~m}^{3}$ (8 $\left.\mathrm{kgal}\right)$ of potential leakage, while the second leakage condition is based on an . upper bounding estimate of $151.4 \mathrm{~m}^{3}(40 \mathrm{kgal})$ of potential leakage. In each case, solution concentrations and inventories will be based on the limiting conditions for waste retrieval, either a maximum supernate concentration of five gram moles per liter sodium or a maximum value of 10 weight percent solids in the slurry, or the total volume of the retrieval solution. These limits were established to minimize the possible crystallization of sodium rich salts in the slurry transfer lines and slurry pumping problems for the slurry pumps and sluicers. The following estimates are based on the methodology that was established by the standard inventory task.

The solution concentrations resulting from dissolution and slurry with water of the tank waste to the three retrieval scenarios are provided in Tables 9 and 10 for nonradiological and radiological constituents, respectively. Table 9 also provides the limiting volume assessment required for application of sodium loading or solids loading limits and the minimum retrieval water to meet the:limiting volume assessment based upon product-specific gravities of either 1.17 or 1.18 for sodium limited or solids limited solutions.

mentar.

Tables: 11 and 12 contain the nonradiological and radiological, resultant leakage inventory estimates based upon $30.2 \mathrm{~m}^{3}$. (8 kgal) and $151.4 \mathrm{~m}^{3}$ (40 kgal) releases during retrieval.

\subsection{TANK LEAKAGE}

In:August 1988, Tank 241-AX-10 was declared an assumed leaker with $11.35 \mathrm{~kL}$ (3: kgal) of potential leakage: A liquid grab sample was taken in November 1988 to establish the composition of the liquid to be pumped out of the tank by saltwell pumping: This sample contained no solids; but analysis of the liquid firmly identifies the waste as CC waste (Table 4).

An occurrence report was filed April 9, 1975 detailing the observed radiation increase in dry well 11-04-11, located about 3.05 m (10 ft) northwest of Tank 241-AX-104. Apparently, a two-fold increase in radiation count was found at the $12.19 \mathrm{~m}$ ( $40 \mathrm{ft})$ level shortly after the well was drilled in January 1975. Based on auger testing of the soil, the soil around the vapor exhaust header was found to be highly contaminated, with readings as high as 3 RAD at contact. This finding relates to a similar finding near the vapor exhaust header joint between Tanks 241-AX-101 and 241-AX-102. If this is the leakage source of interest for Tank 241-AX-102, most of the leakage must have been caused by tank condensates that collected in the exhaust header system. Since the composition of this condensate is not known, we have no basis at the present-time for estimating the chemical and radionuclide source terms for condensate leakage. However, upper bounding estimates could be developed from the supernate composition data for this tank and used as such to evaluate any condensate leakage that might have occurred at the vapor exhaust header between Tanks 241-AX-101 and 241-AX-102.

If the leakage event occurred during the mid to late 1980 s as suggested by the 1988 leakage declaration, we should be able to generate reasonable estimates for the relevant source terms from the 1988 supernate composition data for this tank. The supernate composition and 
estimated inventories of chemicals and radionuclides that might have leaked from the tank during this period are summarized in Table 13.

\subsection{REFERENCES}

Agnew, S. F., J. Boyer, R. Corbin, T. Duran, J. FitzPatrick, K. Jurgensen, T. Ortiz, and B. Young, 1997a, Hanford Tank Chemical and Radionuclide Inventories: HDW Model Rev. 4, LA-UR-96-3860, Los Alamos National Laboratory, Los Alamos, New Mexico.

Agnew, S. F., R. A. Corbin, T. B. Duran, K. A. Jurgensen, T. P. Ortiz, and B. L. Young, 1997b, ... Waste Status and Transaction Records Summary (WSTRS Rev. 4), LA-UR-97-311, Rev.

. . 0, Los Alamos National Laboratory, Los Alamos, New Mexico.

Douglas, J. G., J. Jo, L. C. Amato, J. D. Franklin and T. T. Tran, March 1996, Tank Characterization Report for Double Shell Tank 241-AN-102, WHC-SD-WM-ER-545, Rev. 0, Westinghouse Hanford Company, Richland, Washington.

Ecology, EPA, and DOE, 1990, Hanford Federal Facility Agreement and Consent Order, 2 Aune: vols., as amended, Washington State Department of Ecology, U.S. Environmentäl Protection Agency, U.S. Department of Energy, Olympia, Washington.

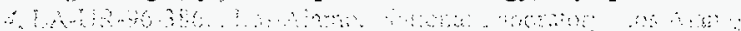

Hanlon, B. M., 1996, Waste Tank Summary Report for Month Ending May 31, 1996,

A., WHC-EP-182-99, Westinghouse Hanford Company, Richland, Washington.

Herting, D. L., 1993, Tank 241-AN-107 Caustic Demand, (internal memorandum 12110-PCL93-042 to K. G. Carothers, May 13), Westinghouse Hanford Company, Dos... Richland, Washington.

Herting;D: L, 1994a; Characterization of Sludge Samples from Tank 241-AN-107, (internal memorandum 8E110-PCL94-064 to K. G. Carothers, August 10), Westinghouse Hanford Company; Richland, Washington.

Herting, D. L, 1994b, Characterization of Supernate Samples from Tank 241-AN-102, (internal memorandum 8E110-PCL94-112 to J.M: Jones, December 28), Westinghouse Hanford and Company, Richland, Washington.

Herting, D. L., 1996, Tank 241-AN-102 Caustic Demand and Sludge Characterization, (internal ....... memorandum 75764-PCS96-085 to.K. G. Carothers; August 22), Westinghouse Hanford Company, Richland, Washington.

Kupfer, M. J., M. D. LeClair, W. W. Schulz, and L. W. Shelton, 1995; Work Plan for Defining $A$ Standard Inventory Estimate for Wastes Stored in Hanford Site Underground Tanks, WHC-SD-WM-WP-311, Rev. 0, Westinghouse Hanford Company, Richland; Washington. 
(formally known as)

Kupfer, M.J., A. L. Boldt, B. A. Higley, K. M. Hodgson, L. W. Shelton, and R. A. Watrous (LMHC), S. L. Lambert, and D. E. Place (SESC), R. M. Orme (NHC), G. L. Borsheim (Borsheim Associates), N. G. Colton (PNNL), M. D. LeClair (SAIC), and R. T. Winward (Meier Associates), and W. W. Schulz (W'2 Corporation), 1997, Standard Inventories of Chemicals and Radionuclides in Hanford Site Tank Wastes, HNF-SD-WM-TI-740, Rev. 0 , (to be issued), Lockheed Martin Hanford Corporation, Richland, Washington.

Swaney, S. L., 1993, Waste Level Discrepancies between Manual Level Readings and Current Waste Inventory for Single Shell Tanks, (internal memorandum 7C242-93-038 to G. T. Frater, December 10), Westinghouse Hanford Company, Richland, Washington. 
HNF-SD-HTI-TI-001, REV. 0

(formally known as)

Table 1. Volume Data (in kgal/kL) for Tank 241-AX-102 Sludge and Saltcake ${ }^{2}$

\begin{tabular}{|c|c|c|c|c|c|c|c|c|}
\hline & \multicolumn{2}{|c|}{ Hanlon } & \multicolumn{2}{c|}{ Swaney } & \multicolumn{2}{c|}{ Agnew } & \multicolumn{2}{c|}{ Best-Basis } \\
\hline & kgal & kL & kgal & kL & kgal & kL & kgal & kL \\
\hline Sludge & 7 & 26.5 & -- & -- & 6 & 23 & 7 & 26.5 \\
\hline Saltcake & 29 & 110 & -- & -- & 33 & 125 & 26 & 98.4 \\
\hline Supernate & 3 & 11 & -- & -- & 0 & 0 & 0 & 0 \\
\hline Total & 39 & 148 & 33 & 125 & 39 & 148 & 33 & 125 \\
\hline
\end{tabular}

a The terms "sludge" and "saltcake" both include the interstitial liquid associated with the solids, which are predominantly water-insoluble metal oxides/hydroxides in the sludge and water-soluble sodium salt crystals in the saltcake.

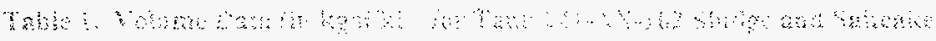

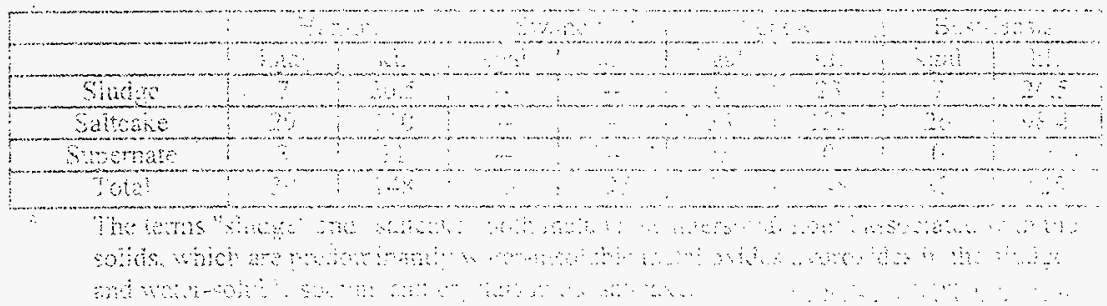


(formally known as)

Table 2. Best-Basis Non radiological Inventory Before Retrieval of Waste From Single-Shell Tank 241-AX-102 (page 1 of 2)

\begin{tabular}{|c|c|c|c|}
\hline & Sludge & Saltcake & Overall \\
\hline Density $\left(\mathrm{kg} / \mathrm{m}^{3}\right)$ & $1,570.0$ & $1,500.0$ & $1,514.8$ \\
\hline Volume $\left(\mathrm{m}^{3}\right)$ & 26.5 & 98.4 & 124.9 \\
\hline \multicolumn{2}{|l|}{ Components (M) } & & Inventory $(\mathrm{kg})$ \\
\hline$\overline{\mathrm{Ag}}$ & $\mathrm{NR}$ & $\mathrm{NR}$ & NR \\
\hline $\mathrm{Al}$ & $1.80 \mathrm{E}+00$ & 7.45E-01 & $3,262.9$ \\
\hline As & $\mathrm{NR}$ & NR & NR: \\
\hline $\mathrm{B}$ & $9.74 \mathrm{E}-03$ & $7.98 \mathrm{E}-01$ & 851.8 \\
\hline $\mathrm{Ba}$ & NR & NR & NR \\
\hline $\mathrm{Bi}$ & & $1.59 \mathrm{E}-03$ & 32.6 \\
\hline $\mathrm{Ca}$ & $1.99 \mathrm{E}-01$ & $2.12 \mathrm{E}-02$ & 294.6 \\
\hline $\mathrm{Cd}$ & $\mathrm{NR}$ & $2.16 \mathrm{E}-05$ & 0.2 \\
\hline $\begin{array}{ll:}\mathrm{Cl} & \\
\end{array}$ & $3.29 \mathrm{E}-02$ & $8.48 \mathrm{E}-02$ & 326.6 \\
\hline IIC as $\mathrm{CO}_{3}$ & $4.52 \mathrm{E}-01$ & $1.59 \mathrm{E}+00$ & $10,092: 5$ \\
\hline $\mathrm{Cr}$ & $4.49 \mathrm{E}-03$ & $3.00 \mathrm{E}-02$ & 159.7 \\
\hline $\mathrm{Cu}$ & $\mathrm{NR}$ & $4.76 \mathrm{E}-03$ & 29.8 \\
\hline$F$ & & $9.47 \mathrm{E}-02$ & 177.2 \\
\hline $\mathrm{Fe}$ & $2.55 \mathrm{E}+00$ & $5.91 \mathrm{E}-02$ & $4,093.8$ \\
\hline $\mathrm{Hg}$ & & $1.21 \mathrm{E}-05$ & 0.2 \\
\hline $\mathrm{K}$ & $7.19 \mathrm{E}-03$ & $4.99 \mathrm{E}-02$ & 199.4 \\
\hline $\mathrm{La}$ & & $3.31 \mathrm{E}-05$ & 0.5 \\
\hline $\mathrm{Mg}$ & $5.73 \mathrm{E}-05$ & $1.32 \mathrm{E}-02$ & 31.6 \\
\hline $\mathrm{Mn}$ & $2.17 \mathrm{E}-01$ & $1.13 \mathrm{E}-02$ & 37.7 .3 \\
\hline $\mathrm{Na}$ & $5.17 \mathrm{E}+00$ & $1.20 \mathrm{E}+01$ & $30,288.1$ \\
\hline $\mathrm{Ni}$ & $9.15 \mathrm{E}-02$ & $8.60 \mathrm{E}-03$ & $192.0^{\circ}$ \\
\hline $\mathrm{NO}_{2}$ & $4.83 \mathrm{E}-01$ & $1.48 \mathrm{E}+00$ & $7,295.6$ \\
\hline $\mathrm{NO}_{3}$ & 5.77E-01 & $3.14 \mathrm{E}+00$ & $20,140.3$ \\
\hline $\mathrm{OH}$ & $7.57 \mathrm{E}+00$ & $8.72 \mathrm{E}+00$ & $18,012.9$ \\
\hline $\mathrm{Pb}$ & $1.20 \mathrm{E}-05$ & $1.92 \mathrm{E}-03$ & 39.2 \\
\hline $\mathrm{P}$ as $\mathrm{PO}_{4}$ & $2.44 \mathrm{E}-02$ & $6.04 \mathrm{E}-02$ & 626.3 \\
\hline $\mathrm{P}$ & $4.07 \mathrm{E}-03$ & $1.24 \mathrm{E}-01$ & 381.0 \\
\hline $\mathrm{Se}$ & NR & $\mathrm{NR}$ & $\mathrm{NR}$ \\
\hline Sias $\mathrm{SiO}_{3}$ & $7.56 \mathrm{E}-0.1$ & $3.65 \mathrm{E}-02$ & $1,797.6$ \\
\hline $\mathrm{S}$ as $\mathrm{SO}_{4}$ & $3.42 \mathrm{E}-02$ & $2.83 \mathrm{E}-01$ & $2,759.0$ \\
\hline $\mathrm{S}$ & $2.15 \mathrm{E}-02$ & $4.60 \mathrm{E}-02$ & 163.3 \\
\hline Sr: & $5.70 \mathrm{E}-02$ & $1.27 \mathrm{E}-05$ & 132.4 \\
\hline TOC & $7.43 \mathrm{E}-02$ & $2.76 \mathrm{E}+00$ & $3,286.2$ \\
\hline 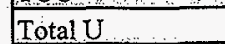 & $6.56 \mathrm{E}-03$ & $1.61 \mathrm{E}-02$ & 419.1 \\
\hline
\end{tabular}


Table 2. Best-Basis Nonradiological Inventory Before Retrieval of Waste From Single-Shell Tank 241-AX-102 (page 2 of 2)

\begin{tabular}{|l|r|r|c|}
\hline & \multicolumn{1}{|c|}{ Sludge } & Saltcake & Overall \\
\hline Density $\left(\mathrm{kg}^{2} \mathrm{~m}^{3}\right)$ & $1,570.0$ & $1,500.0$ & $1,5.14 .8$ \\
\hline Volume $\left(\mathrm{m}^{3}\right)$ & 26.5 & 98.4 & 124.9 \\
\hline Components $(\mathrm{M})$ & & & Inventory $(\mathrm{kg})$ \\
\hline $\mathrm{Zn}$ & $4.22 \mathrm{E}-03$ & $1.64 \mathrm{E}-05$ & 7.4 \\
\hline $\mathrm{Zr}$ & $\mathrm{NR}$ & $1.50 \mathrm{E}-04$ & 1.3 \\
\hline $\mathrm{EDTA}$ & $\mathrm{NR}$ & $3.43 \mathrm{E}-02$ & 987.0 \\
\hline $\mathrm{NH}_{3}$ & $\mathrm{NR}$ & $\mathrm{NR}$ & $\mathrm{NR}$ \\
\hline $\mathrm{Cr}^{+6}$ & $\mathrm{NR}$ & $\mathrm{NR}$ & $\mathrm{NR}$ \\
\hline $\mathrm{CN}$ & $4.98 \mathrm{E}+01$ & $1.34 \mathrm{E}+01$ & $68,670.0$ \\
\hline $\mathrm{H}_{2} \mathrm{O}$ & $1.79 \mathrm{E}-03$ & $1.78 \mathrm{E}-02$ & $3.24 \mathrm{E}+01$ \\
\hline Total & & & $1.75 \mathrm{E}+05$ \\
\hline
\end{tabular}

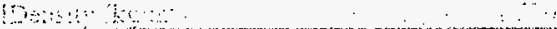

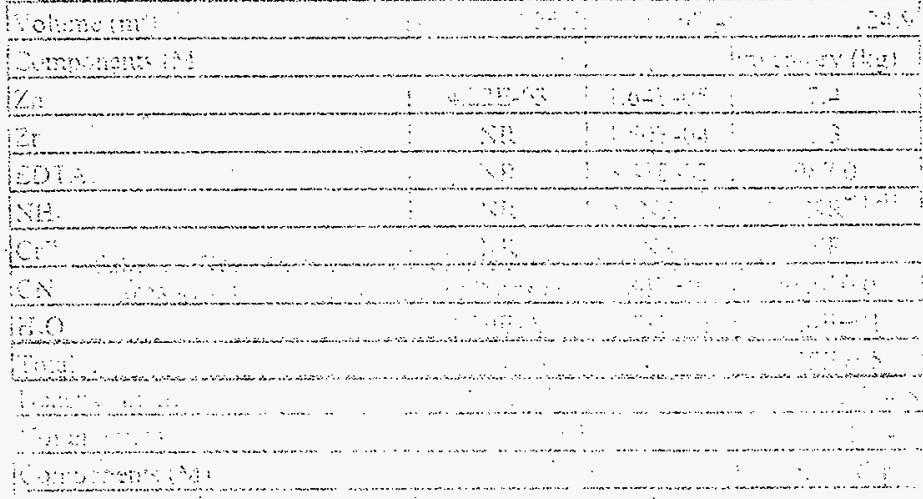

$\therefore+$ 
(formally known as)

Table 3. Best-Basis Radiological Inventory Before Retrieval of Waste From Single-Shell Tank 241-AX-102 (page 1 of 2)

\begin{tabular}{|c|c|c|c|}
\hline Components $(\mathrm{Ci} / \mathrm{L})$. & Sludge & Saltcake ... & Overall (Ci) $\ldots$ \\
\hline Decay Date..... & $12 / 31 / 99$ & $12 / 31 / 99$ & $12 / 31 / 99 \ldots \ldots$ \\
\hline${ }^{3} \mathrm{H} \quad \therefore \quad \ldots \ldots$ & $3.23 \mathrm{E}-05$ & $3.20 \mathrm{E}-04$ & $3.24 \mathrm{E}+01$ \\
\hline${ }^{14} \mathrm{C}$ & $9.96 \mathrm{E}-06$ & $4.91 \mathrm{E}-05$ & $5.09 \mathrm{E}+00$ \\
\hline $59 \mathrm{Ni}$ & 4.83E-05 & $2.89 \mathrm{E}-06$ & $1.56 \mathrm{E}+00$ \\
\hline${ }^{60} \mathrm{Co}$ & $2.39 \mathrm{E}-05$ & $6.08 \mathrm{E}-05$ & $6.61 E+00$ \\
\hline${ }^{63} \mathrm{Ni} \cdots$ & $5.02 \mathrm{E}-03$ & $2.84 \mathrm{E}-04$ & $1.61 E+02$ \\
\hline${ }^{79} \mathrm{Se}$ & $1.82 \mathrm{E}-04$ & $4.87 \mathrm{E}-06$ & $5.29 E+00$ \\
\hline${ }^{90} \mathrm{Sr} \cdots$ & $5.09 \mathrm{E}+00$ & $1.46 \mathrm{E}-01$ & $1.49 \mathrm{E}+05$ \\
\hline${ }^{90} Y$ & $5.09 \mathrm{E}+00$ & $1.46 \mathrm{E}-01$ & $1.49 \mathrm{E}+05$ \\
\hline${ }^{93} \mathrm{mNb}$ & $5.25 \mathrm{E}-04$ & $1.73 \mathrm{E}-05$ & $1.56 \mathrm{E}+01$ \\
\hline${ }^{93} \mathrm{Zr}: \mathrm{O}^{2}$ & $7.93 \mathrm{E}-04$ & $2.40 \mathrm{E}-05$ & $2.34 \mathrm{E}+01$ \\
\hline${ }^{99} \mathrm{Tc} \quad \ldots$ & $6.60 \mathrm{E}-05$ & $3.65 \mathrm{E}-04 \ldots$ & $3.76 \mathrm{E}+01$ \\
\hline${ }^{106} \mathrm{Ru}$ & $2.20 \mathrm{E}-05$ & $1.05 \mathrm{E}-08$ & $5.85 \mathrm{E}-01$ \\
\hline${ }^{113} \mathrm{mCd}$ & $3.96 \mathrm{E}-03$ & $1.30 \mathrm{E}-04:$ & $1.18 \mathrm{E}+02$ \\
\hline${ }^{125} \mathrm{Sb}$ & $1.49 \mathrm{E}-04$ & $2.72 \mathrm{E}-04$ & $3.08 \mathrm{E}+01$ \\
\hline${ }^{126} \mathrm{Sn}$ & $2.88 \mathrm{E}-04$ & $7.35 \mathrm{E}-06$ & $8.34 \mathrm{E}+00$ \\
\hline${ }^{129} \mathrm{I}$ & $1.29 \mathrm{E}-07$ & $7.05 \mathrm{E}-07$ & $7.28 \mathrm{E}-02$ \\
\hline${ }^{134} \mathrm{Cs}$ & $1.15 \mathrm{E}_{-06}$ & $4.81 \mathrm{E}-06$ & $5.04 \mathrm{E}-01$ \\
\hline${ }^{135} \mathrm{Cs}$ & NR & NR & NR \\
\hline${ }^{137} \mathrm{Cs}$ & $7.04 \mathrm{E}-01$ & $3.04 \mathrm{E}-01$ & $4.86 \mathrm{E}+04$ \\
\hline${ }^{137} \mathrm{mBa}$ & $6.66 \mathrm{E}-01$ & $2.87 \mathrm{E}-01$ & $4.59 \mathrm{E}+04$ \\
\hline${ }^{15 !} \mathrm{Sm}$ & $5.23 \mathrm{E}-01$ & $1.71 \mathrm{E}-02$ & $1.55 \mathrm{E}+04$ \\
\hline${ }^{152} \mathrm{Eu} \quad \therefore \therefore$ & $7.70 E-04$ & $6.33 \mathrm{E}-06$ & $2.10 \mathrm{E}+01$ \\
\hline${ }^{154} \mathrm{Eu}$ & $5.89 \mathrm{E}-02$ & $9.47 \mathrm{E}-04$ & $1.65 \mathrm{E}+03$ \\
\hline${ }^{155} \mathrm{Eu}$ & $3.73 \mathrm{E}-02$ & $3.75 \mathrm{E}-04$ & $1.03 E+03$ \\
\hline${ }^{226} \mathrm{Ra}$ & $8.11 \mathrm{E}-09$ & $1.91 E-10$ & $2.34 \mathrm{E}-04$ \\
\hline${ }^{227} \mathrm{Ac}$ & $3.85 \mathrm{E}-08$ & $1.19 \mathrm{E}-09$ & $1.14 \mathrm{E}-03$ \\
\hline${ }^{228} \mathrm{Ra}$ & $3.22 \mathrm{E}-13$ & $3.85 \mathrm{E}-07$ & $3.79 \mathrm{E}-02$ \\
\hline${ }^{229} \mathrm{Th}$ & $3.02 \mathrm{E}-11$ & $8.95 \mathrm{E}-09$ & $8.82 \mathrm{E}-04$ \\
\hline${ }^{231} \mathrm{~Pa}$ & $1.20 \mathrm{E}-09$ & $5.68 \mathrm{E}-09$ & $5.91 \mathrm{E}-04$ \\
\hline${ }^{232} \mathrm{Th}$ & $4.19 \mathrm{E}-15$ & $3.92 \mathrm{E}-08$ & $3.86 \mathrm{E}-03$ \\
\hline${ }^{232} \mathrm{U}$ & $1.57 \mathrm{E}-11$ & $1.28 \mathrm{E}-06$ & $1.26 \mathrm{E}-01$ \\
\hline${ }^{233} \mathrm{U}$ & $2.08 \mathrm{E}-13$ & $4.90 \mathrm{E}-06$ & $4.82 E-01$ \\
\hline${ }^{234} \mathrm{U}$ & $5.59 \mathrm{E}-08$ & $9.91 \mathrm{E}-07$ & $9.90 \mathrm{E}-02$ \\
\hline${ }^{235} \mathrm{U}:$ & $2.14 \mathrm{E}-09$ & $3.96 \mathrm{E}-08$ & $3.96 \mathrm{E}-03$ \\
\hline${ }^{236} \mathrm{U}$ & $4.30 \mathrm{E}-09$ & $3.17 \mathrm{E}-08$ & $3.23 \mathrm{E}-03$ \\
\hline${ }^{237} \mathrm{~Np}$ & $2.13 \mathrm{E}-07$ & $1.29 \mathrm{E}-06$ & $1.33 \mathrm{E}-01$ \\
\hline
\end{tabular}


HNF-SD-HTI-TI-001, REV. 0

SESC-EN-RPT-002, Rev. 1

Table 3. Best-Basis Radiological Inventory Before Retrievarmal (fy known as)
From Single-Shell Tank 241-AX-102 (page 2 of 2)

\begin{tabular}{|c|c|c|c|}
\hline Components $(\mathrm{Ci} / \mathrm{L})$ & Sludge & Saltcake & Overall (Ci) \\
\hline Decay Date & $12 / 31 / 99$ & $12 / 31 / 99$ & $12 / 31 / 99$ \\
\hline${ }^{238} \mathrm{Pu}$ & $2.28 \mathrm{E}-03$ & $1.95 \mathrm{E}-06$ & $6.07 \mathrm{E}+01$ \\
\hline${ }^{238} \mathrm{U}$ & $4.19 \mathrm{E}-08$ & $1.28 \mathrm{E}-06$ & $1.27 \mathrm{E}-01$ \\
\hline${ }^{239} \mathrm{Pu}$ & $1.54 \mathrm{E}-02$ & $6.34 \mathrm{E}-05$ & $4.15 \mathrm{E}+02$ \\
\hline${ }^{240} \mathrm{Pu}$ & $5.55 \mathrm{E}-03$ & $1.10 \mathrm{E}-05$ & $1.48 \mathrm{E}+02$ \\
\hline${ }^{239 / 240} \mathrm{Pu}$ & $2: 10 \mathrm{E}-02$ & $7.44 \mathrm{E}-05$ & $5.63 \mathrm{E}+02$ \\
\hline${ }^{241} \mathrm{Am}$ & $4.98 \mathrm{E}-02$ & $8.04 \mathrm{E}-05$ & $133 \mathrm{E}+03$ \\
\hline${ }^{24 \mathrm{Pu}}$ & $1.58 \mathrm{E}-01$ & $1.34 \mathrm{E}-04$ & $4.19 \mathrm{E}+03$ \\
\hline 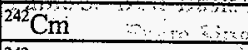 & $6.64 \mathrm{E}-05$ & $2.35 \mathrm{E}-07$ & $1.78 \mathrm{E}+00$ \\
\hline${ }^{242} \mathrm{mAm}$ & NR & NR & NR \\
\hline${ }^{242} \mathrm{Pu} \quad \mathrm{a}$ & $1.14 \mathrm{E}-06$ & $7.42 \mathrm{E}-10$ & $3: 04 \mathrm{E}-02$ \\
\hline $243 \mathrm{Am}$ & $5.59 \mathrm{E}-06$ & $3.09 \mathrm{E}-09$ & $1.48 \mathrm{E}-01$ \\
\hline${ }^{243} \mathrm{Cm}$ & 8:15E 06 & $2.26 \mathrm{E}-08$ & $2.18 \mathrm{E}-01$ \\
\hline${ }^{244} \mathrm{Cm}$ & $3.37 \mathrm{E}-04$ & $1.75 \mathrm{E}-07$ & $8.96 \mathrm{E}+00$ \\
\hline Tótal & $1 \div 02$ & 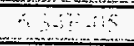 & $4.18 \mathrm{E}+05$ \\
\hline 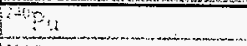 & 5820 & 90 & $-3-2$ \\
\hline mis & 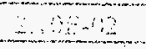 & $\therefore-6$ & 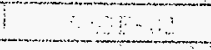 \\
\hline $2+\mathrm{Bm}$ & 8606 & 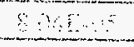 & 82 \\
\hline $\begin{array}{l}4 \\
4\end{array}$ & 80 & $\begin{array}{r}4 \\
86 \\
6\end{array}$ & $\begin{array}{c}+4 \cdot 3 \\
6\end{array}$ \\
\hline $6 \mathrm{sm}$ & 8 & 5 & 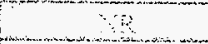 \\
\hline 4, & 50 & 58 & \\
\hline 30 & $3+10$ & $\therefore \cdots$ & -2 \\
\hline Si: & $8,-60$ & $3 y+1 \times x$ & 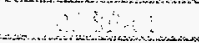 \\
\hline 4 & & & 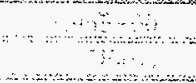 \\
\hline
\end{tabular}


Table 4. Comparison of 1988 Supernatant Liquid Sample from Tank 241-AX-102 with Supernatant Liquid Samples from Concentrated Complexed Waste Tanks 241-AN-102 and 241-AN-107 (concentrations in molarity except as noted)

\begin{tabular}{|c|c|c|c|}
\hline Component & $\begin{array}{c}241-\mathrm{AX}-102^{\mathrm{a}} \\
(\mathrm{M})\end{array}$ & $\begin{array}{c}\text { 241-AN-102 } \\
(\mathrm{M}) \\
\end{array}$ & $\begin{array}{c}241-\mathrm{AN}-107^{\mathrm{c}} \\
\text { (M) }\end{array}$ \\
\hline $\mathrm{NO}_{3}$ & 3.7. & 3.6 & 3.8 \\
\hline $\mathrm{NO}_{2}$ & 1.4 & 1.8 & $1: 1$ \\
\hline $\mathrm{CO}_{3}$ & 0.98 & 1.1 & 1.2 \\
\hline $\operatorname{TOC}(\mathrm{g} / \mathrm{L})$ & 36.8 & 26.3 & 42.9 \\
\hline $\mathrm{Al}$ & 0.006 & 0.55 & 0.044 \\
\hline $\mathrm{Ca}$ & 0.014 & 0.011 & $\mathrm{NR}$ \\
\hline $\mathrm{Fe}$ & 0.033 & $\cdots \mathrm{NR}$ & 0.027 \\
\hline $\mathrm{Na}$ & 7.32 & $112+\cdots+1-1$ & -8.6 \\
\hline${ }^{241} \mathrm{Am}(\mu \mathrm{Ci} / \mathrm{mL})$ & 1.0 & $\mathrm{NR}$ & 0.63 \\
\hline${ }^{-239 / 240} \mathrm{Pü}(\mathrm{jCl} / \mathrm{mL})$ & 0.097 & $\mathrm{NR}$ & 0.034 \\
\hline${ }^{-137} \mathrm{Cs}(\mu \mathrm{Ci} / \mathrm{mL})$ & 350 & 382 & 253 \\
\hline${ }^{-90} \mathrm{Sr}(\mu \mathrm{Ci} / \mathrm{mL})$ & 175 & 74 & 93 \\
\hline
\end{tabular}

1988 grab sample from Tank $241-\mathrm{AX}=102$.

${ }^{6}$ Herting 1993.

' Herting 1994b. 
(formally known as)

Table 5. Comparison of Supernate Mixing Model, Samples from Tanks 241-AN-102 and 241-AN-107 and Best-Basis Saltcake Composition Estimates for the Saltcake Layer in Tank 241-AX-102

(values in ug/g, except as noted)

\begin{tabular}{|c|c|c|c|c|c|}
\hline Component & $\begin{array}{c}\text { SMM } \\
\text { estimates for } \\
241-\mathrm{AX}-102^{\mathrm{a}} \\
\end{array}$ & $241-\mathrm{AN}-102^{\mathrm{b}}$ & $\begin{array}{l}241-\mathrm{AN}-10 \\
2^{\mathrm{c}}\end{array}$ & $241-A N-107^{d}$ & $\begin{array}{c}\text { Best-Basis } \\
\text { Saltcake } \\
\text { Composition } \\
\end{array}$ \\
\hline $\begin{array}{l}\text { Density } \\
(\mathrm{g} / \mathrm{mL})\end{array}$ & 1.53 & 1.53 & 1.50 & 1.47 & 1.50 \\
\hline $\mathrm{Wt} \% \mathrm{H}_{2} \mathrm{O}$ & 39.3 & 41.0 & 40.3 & 45.6 & 42.3 \\
\hline $\mathrm{Na}$ & 169,000 & 177,000 & 234,000 & 140,500 & 184,000 \\
\hline $\mathrm{Al}$ & $\therefore 27,900$ & 12,000 & 12,200 & 16,000 & 13,400 \\
\hline $\mathrm{Fe}$ & 236 & 1,200 & 1,500 & $3,900^{\circ}$ & 2,200 \\
\hline $\mathrm{Cr}$ & 1,720 & 1,300 & 1,370 & 450 & 1,040 \\
\hline $\mathrm{Pb}$ & 157 & 200 & $<270$ & 330 & 265 \\
\hline $\mathrm{Ni}$ & 208 & 260 & 420 & 330 & 337 \\
\hline $\mathrm{Mn}$ & $\begin{array}{r}152 \\
\end{array}$ & 250 & 480 & 5.10 & (1) 413 \\
\hline $\mathrm{Ca}$ & 767 & $450^{\circ}$ & 810 & 440 & 567 \\
\hline $\mathrm{K}$ & $1,400^{-}$ & 1,500 & $<1,700$ & 1,100 & 1,300 \\
\hline $\mathrm{NO}_{3}$ & 183,000 & 136,000 & 112,000 & 142,000 & 130,000 \\
\hline $\mathrm{NO}_{2}$ & 69,900 & 55,000 & 39,300 & 42,000 & 45,400 \\
\hline $\mathrm{CO}_{3}$ & 92,000 & 80,000 & 61,500 & 49,000 & 63,500 \\
\hline $\mathrm{PO}_{4}$ & 5,420 & 4,400 & 3,030 & 4,050 & 3,830 \\
\hline $\mathrm{SO}_{4}$ & 16,300 & 20,000 & 25,900 & 8,400 & $18 ; 100 \cdots$ \\
\hline $\mathrm{F}$ & 873 & 1,250 & $<<90^{\circ}$ & 1,150 & 1,200 \\
\hline $\mathrm{Cl}^{-}$ & 4,620 & 2,600 & $2,060^{\circ}$ & 1,350 & 2,000 \\
\hline $\mathrm{TOC}$ & $11,800^{\circ}$ & 23,000 & 16,300 & $27,000^{\circ}$ & 22,100 \\
\hline $\begin{array}{c}-239840 \mathrm{Pu} \\
(\mu \mathrm{Ci} / \mathrm{g})\end{array}$ & $\begin{array}{r}0.05 \\
- \\
\end{array}$ & $\mathrm{NR}$ & $\begin{array}{l}\text { NR } \\
\vdots\end{array}$ & 0.085 & 0085 \\
\hline${ }^{137} \mathrm{Cs}(\mu \mathrm{Ci} / \mathrm{g})$ & 184 & 215 & 285 & 300 & $232^{\mathrm{e}}$ \\
\hline${ }^{90} \mathrm{Sr}-(\mathrm{HC} / \mathrm{g})$ & -72 & $\begin{array}{r}105 \\
-10\end{array}$ & 169 & 115 & $113^{\mathrm{e}}$ \\
\hline
\end{tabular}

${ }^{a}$ Agnew et al. (1996)

b-based on grab samples taken in 1994 and 1995 (Herting 1996)

cbased on core sample taken in 1990 (Douglas 1996)

based on grab samples taken in 1994. (Herting 1994)

average of analytical data in columns 3-5. Radionuclides decayed to December 31, 1999. 
Table 6. Retrieval Scenario Summary of Residual Waste and Fractional Removal

\begin{tabular}{|l|r|r|r|}
\hline & Case I & \multicolumn{1}{c|}{ Case II } & Case III \\
\hline Volume Base $\left(\mathrm{m}^{3}\right)$ & 101.94 & 10.19 & 1.02 \\
\hline$\%$ Base & $90.0 \%$ & $99.0 \%$ & $99.9 \%$ \\
\hline Target $\left(\mathrm{m}^{3}\right)$ & 101.94 & 10.19 & 1.02 \\
\hline Sludge $\left(\mathrm{m}^{3}\right)$ & 26.50 & 10.19 & 1.02 \\
\hline Saltcake $\left(\mathrm{m}^{3}\right)$ & 75.44 & 0.00 & 0.00 \\
\hline Sludge Removal & $0.0 \%$ & $61.5 \%$ & $96.2 \%$ \\
\hline Saltcake Removal & $23.3 \%$ & $100.0 \%$ & $100.0 \%$ \\
\hline
\end{tabular}

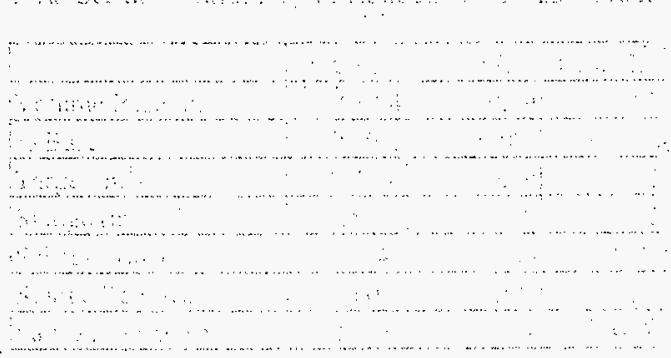


Table 7. Tank 241-AX-102 Nonradiological Waste Residual (formally known as) Inventory Following Retrieval (page 1 of 2)

\begin{tabular}{|c|c|c|c|}
\hline Resicual Waste $(\mathrm{kg})$ & Case I & Case II & Case III \\
\hline Target $\left(\mathrm{m}^{3}\right) \cdots \cdots \cdots$ & 101.94 & $\begin{array}{r}10.19 \\
\end{array}$ & 1.02 \\
\hline Sludge $\left(\mathrm{m}^{3}\right)$ & 26.50 & $\therefore \quad 10: 19$ & $\therefore \quad 1.02$ \\
\hline Saltcake $\left(\mathrm{m}^{3}\right)$ & $\therefore 75.44$ & $\because \quad 0.00$ & 0.00 \\
\hline $\mathrm{Ag} \cdots$ & $\mathrm{NR}$ & NR & $\mathrm{NR}$ \\
\hline $\mathrm{Al} \quad \cdots$ & $2.80 \mathrm{E}+03$ & $4.94 \mathrm{E}+02$ & $4.94 \mathrm{E}+01$ \\
\hline As & $\mathrm{NR}$ & NR & $\mathrm{NR}$ \\
\hline $\mathrm{B}$ & $6.54 \mathrm{E}+02$ & $1.07 \mathrm{E}+00$ & $1.07 \mathrm{E}-01$ \\
\hline $\mathrm{Ba}$ & NR. & $\mathrm{NR}$ & NR \\
\hline & $2.50 \mathrm{E}+01$ & NR & NR \\
\hline $\mathrm{Ca}$ & $2.75 \mathrm{E}+02$ & $8.11 \mathrm{E}+01$ & $8.11 E+00$ \\
\hline $\mathrm{Cd}: \therefore$ & $1.83 \mathrm{E}-01$ & NR & $\mathrm{NR}$ \\
\hline $\mathrm{Cl}: \mathrm{a}$ & $2.58 \mathrm{E}+02$ & $1.19 \mathrm{E}+01$ & $1.19 \mathrm{E}+00$ \\
\hline $\mathrm{TIC}$ as $\mathrm{CO}_{3}$ & $7.90 \mathrm{E}+03$ & $2.76 \mathrm{E}+02$ & $2.76 \mathrm{E}+01$ \\
\hline $\mathrm{Cr}$ & $1.24 \mathrm{E}+02$ & $2.38 \mathrm{E}+00$ & $2.38 \mathrm{E}-01$ \\
\hline $\mathrm{Cu}$ & $2.28 \mathrm{E}+01$ & NR & $\mathrm{NR}$ \\
\hline F: & $1.36 \mathrm{E}+02$ & $\mathrm{NR}$ & NR \\
\hline $\mathrm{Fe}$ & $4.02 \mathrm{E}+03$ & $1.45 \mathrm{E}+03$ & $1.45 \mathrm{E}+02$ \\
\hline $\mathrm{Hg}$ & $1.83 \mathrm{E}-01$ & NR & NR \\
\hline$K$ & $1.55 \mathrm{E}+02$ & $2.86 \mathrm{E}+00$ & $2.86 \mathrm{E}-01$ \\
\hline $\mathrm{La}$ & $3.46 \mathrm{E}=01$ & NR. & NR \\
\hline $\mathrm{Mg}$ & $2.43 \mathrm{E}+01$ & $1.42 \mathrm{E}-02$ & $1.42 \mathrm{E}-03$ \\
\hline $\mathrm{Mn}$ & $3.63 \mathrm{E}+02$ & $1.22 \mathrm{E}+02$ & $1.22 \mathrm{E}+01$ \\
\hline $\mathrm{Na}$ & $2.40 \mathrm{E}+04$ & $1.21 \mathrm{E}+03$ & $1.21 \mathrm{E}+02$ \\
\hline $\mathrm{Ni}$ & $1.80 \mathrm{E}+02$ & $5.47 \mathrm{E}+01$ & $5.47 \mathrm{E}+00$ \\
\hline $\mathrm{NO}_{2}$ & $5.73 \mathrm{E}+03$ & $2.26 \mathrm{E}+02$ & $2.26 \mathrm{E}+01$ \\
\hline $\mathrm{NO}_{3}$ & $1.57 \mathrm{E}+04$ & $3.65 \mathrm{E}+02$ & $3.65 \mathrm{E}+01$ \\
\hline $\mathrm{OH}$ & $1.46 \mathrm{E}+04$ & $1.31 \mathrm{E}+03$ & $1.31 \mathrm{E}+02$ \\
\hline $\mathrm{Pb}$ & $3.01 \mathrm{E}+01$ & $2.53 \mathrm{E}-02$ & $2.53 E-03$ \\
\hline $\mathrm{Pas} \mathrm{PO}_{4}$ & $4.94 \mathrm{E}+02$ & $2.36 \mathrm{E}+01$ & $2.36 \mathrm{E}+00$ \\
\hline $\mathrm{P}$ & $2.93 \mathrm{E}+02$ & $1.28 \mathrm{E}+00$ & $1.28 \mathrm{E}-01$ \\
\hline $\mathrm{Se}$ & $\mathrm{NR}$ & NR & NR \\
\hline Sias $\mathrm{SiO}_{3}$ & $1.73 \mathrm{E}+03$ & $5.87 \mathrm{E}+02$ & $5.87 \mathrm{E}+01$ \\
\hline $\mathrm{Sas} \mathrm{SO}_{4}$ & $2.14 \mathrm{E}+03$ & $3.35 \mathrm{E}+01$ & $3.35 \mathrm{E}+00$ \\
\hline$S$ & $1.29 \mathrm{E}+02$ & $7.04 \mathrm{E}+00$ & $7.04 \mathrm{E}=01$ \\
\hline $\mathrm{Sr}$ & $1.32 \mathrm{E}+02$ & $5.09 \mathrm{E}+01$ & $5.09 \mathrm{E}+00$ \\
\hline TOC & $2.52 \mathrm{E}+03$ & $9.10 \mathrm{E}+00$ & $9.10 \mathrm{E}=01$ \\
\hline Tótal U & $3.31 \mathrm{E}+02$ & $1.59 \mathrm{E}+01$ & $1.59 \mathrm{E}+00$ \\
\hline
\end{tabular}


Table 7. Tank 241-AX-102 Nonradiological Waste Resirmal hy known as) Inventory Following Retrieval (page 2 of 2)

\begin{tabular}{|l|c|c|c|}
\hline Residual Waste $(\mathrm{kg})$ & Case I & Case II & Case III \\
\hline $\mathrm{Zn}$ & $7.38 \mathrm{E}+00$ & $2.81 \mathrm{E}+00$ & $2.81 \mathrm{E}-01$ \\
\hline $\mathrm{Zr}$ & $1.03 \mathrm{E}+00$ & $\mathrm{NR}$ & $\mathrm{NR}$ \\
\hline $\mathrm{EDTA}$ & $7.57 \mathrm{E}+02$ & $\mathrm{NR}$ & $\mathrm{NR}$ \\
\hline $\mathrm{NH}_{3}$ & $\mathrm{NR}$ & $\mathrm{NR}$ & $\mathrm{NR}$ \\
\hline $\mathrm{Cr}^{6}$ & $\mathrm{NR}$ & $\mathrm{NR}$ & $\mathrm{NR}$ \\
\hline $\mathrm{CN}$ & $6.07 \mathrm{E}+04$ & $1.32 \mathrm{E}+04$ & $1.32 \mathrm{E}+03$ \\
\hline $\mathrm{H}_{2} \mathrm{O}$ & $2.50 \mathrm{E}+01$ & $3.29 \mathrm{E}-01$ & $3.29 \mathrm{E}-02$ \\
\hline Total & $1.46 \mathrm{E}+05$ & $1.95 \mathrm{E}+04$ & $1.95 \mathrm{E}+03$ \\
\hline
\end{tabular}

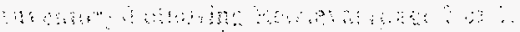


HNF $\angle$ SD $=$ HTI-TI $-00 I$, REV, 0

SESC-EN-RPT-002, Rev. 1

(formally known as)

Table 8. Tank 241-AX-102 Radiological Waste Residual Inventory Following Retrieval (page 1 of 2)

\begin{tabular}{|c|c|c|c|}
\hline Residual Waste (Ci) & Case I & Case II & Case III \\
\hline Decay Date & $12 / 31 / 99$ & $12 / 31 / 99$ & $12 / 31 / 99$ \\
\hline${ }^{3} \mathrm{H}$ & $2.50 \mathrm{E}+01$ & $3.29 \mathrm{E}-0 \mathrm{I}$ & $3.29 \mathrm{E}-02$ \\
\hline${ }^{14} \mathrm{C}$ & $3.97 \mathrm{E}+00$ & $1.02 \mathrm{E}-01$ & $1.02 \mathrm{E}-02$ \\
\hline $59 \mathrm{Ni}$ & $1.50 \mathrm{E}+00$ & $4.92 \mathrm{E}-0 \mathrm{l}$ & $4.92 \mathrm{E}-02$ \\
\hline${ }^{60} \mathrm{Co}$ & $5.22 \mathrm{E}+00$ & $2.44 \mathrm{E}-01$ & $2.44 \mathrm{E}-02$ \\
\hline${ }^{63} \mathrm{Ni}$ & $1.54 \mathrm{E}+02$ & $5.12 \mathrm{E}+01$ & $5.2 \mathrm{E}+00$ \\
\hline${ }^{79} \mathrm{Se}$ & $5.18 \mathrm{E}+00$ & $1.85 \mathrm{E}+00$ & $1.85 \mathrm{E}-01$ \\
\hline${ }^{90} \mathrm{Sr}$ & $1.46 \mathrm{E}+0.5$ & $5.19 \mathrm{E}+04$ & $5.19 \mathrm{E}+03$ \\
\hline${ }^{90} \mathrm{Y}$ & $1,46 \mathrm{E}+05$ & $5.19 \mathrm{E}+04$ & $5.19 E+03$ \\
\hline${ }^{93} \mathrm{mNb}$ & $1.52 \mathrm{E}+01$ & $5.35 \mathrm{E}+00$ & $5.35 \mathrm{E}-01$ \\
\hline $93 \mathrm{Zr} \backsim \mathrm{ai} \quad \mathrm{Q}$ & $2.28 \mathrm{E}+01$ & $8.08 \mathrm{E}+00$ & $8.08 \mathrm{E}-01$ \\
\hline $\mathrm{Tc}$ & $2.93 \mathrm{E}+01$ & $6.73 \mathrm{E}-01$ & $6.73 \mathrm{E}-02$ \\
\hline${ }^{106} \mathrm{Ru}$ & $5.85 \mathrm{E}-01$ & $2.25 \mathrm{E}-01$ & $2.25 \mathrm{E}-02$ \\
\hline${ }^{113 \mathrm{mCd}}$ & $1.15 E+02$ & $4.04 \mathrm{E}+01$ & $4.04 \mathrm{E}+00$ \\
\hline${ }^{125} \mathrm{Sb}$ & $2.45 \mathrm{E}+01$ & $1.52 \mathrm{E}+00$ & $1.52 \mathrm{E}-01$ \\
\hline${ }^{126} \mathrm{Sn}$ & $8.17 \mathrm{E}+00$ & $2.93 \mathrm{E}+00$ & $2.93 \mathrm{E}-01$ \\
\hline 129 & $5.66 \mathrm{E}-02$ & $1.31 \mathrm{E}=03$ & 1.3.1E-04 \\
\hline${ }^{134} \mathrm{Cs}$ & $3.93 \mathrm{E}-01$ & $1.17 \mathrm{E}=02$ & $1.17 \mathrm{E}-03$ \\
\hline${ }^{135} \mathrm{Cs}$ & $\mathrm{NR}$ & $\mathrm{NR}$ & $\mathrm{NR}$ \\
\hline${ }^{137} \mathrm{Cs}$ & $4.16 \mathrm{E}+04$ & $7.17 \mathrm{E}+03$ & $7.17 \mathrm{E}+02$ \\
\hline${ }^{137} \mathrm{mBa}$ & $3.93 E+04$ & $6.79 \mathrm{E}+03$ & $6.79 \mathrm{E}+02$ \\
\hline${ }^{15} \mathrm{Sm}$ & $1.51 \mathrm{E}+04$ & $5.33 E+03$ & $5: 33 \mathrm{E}+02$ \\
\hline${ }^{152} \mathrm{Eu}$ & $2.09 \mathrm{E}+0 \mathrm{i}$ & $7.85 \mathrm{E}+00$ & $7.85 \mathrm{E}-01$ \\
\hline${ }^{154} \mathrm{Eu}$ & $1.63 \mathrm{E}+03$ & $6.00 \mathrm{E}+02$ & $6.00 \mathrm{E}+01$ \\
\hline${ }^{155} \mathrm{Eu}$ & $1.02 \mathrm{E}+03$ & $3.80 \mathrm{E}+02$ & $3.80 \mathrm{E}+01$ \\
\hline${ }^{226} \mathrm{Ra}$ & $2.29 \mathrm{E}-04$ & $8.27 \mathrm{E}-0 \mathrm{~S}$ & $8.27 \mathrm{E}-06$ \\
\hline${ }^{227} \mathrm{Ac}$ & $111 \mathrm{E}-03$ & $3.92 \mathrm{E}=04$ & $3.92 \mathrm{E}-05$ \\
\hline${ }^{228} \mathrm{Ra}$ & $2.91 \mathrm{E}-02$ & $3.28 \mathrm{E}-09$ & $3.28 \mathrm{E}-1.0$ \\
\hline${ }^{229} \mathrm{Th}$ & $6.76 \mathrm{E}-04$ & $3.08 \mathrm{E}-07$ & $3.08 \mathrm{E}-08$ \\
\hline${ }^{23 !} \mathrm{Pa}$ & $4.60 \mathrm{E}-04$ & $1.23 \mathrm{E}-05$ & $1.23 \mathrm{E}-06$ \\
\hline${ }^{232} \mathrm{Th}$ & $2,96 \mathrm{E}-03$ & $4.27 \mathrm{E}-1 \mathrm{~F}$ & $4.27 \mathrm{E}-12$ \\
\hline${ }^{23} \mathrm{US}$ & $9.66 \mathrm{E}-02$ & $1.60 \mathrm{E}-07$ & $1.60 \mathrm{E}-08$ \\
\hline${ }^{233} \mathrm{U}$ & $3,69 \mathrm{E}-01$ & $212 \mathrm{E}-09$ & $212 \mathrm{E}-10$ \\
\hline${ }^{234} \mathrm{U}$ & $7.62 \mathrm{E}-02$ & $5.69 \mathrm{E}-04$ & $5.69 \mathrm{E}-05$ \\
\hline${ }^{235} \mathrm{U}:$ & $3.05 \mathrm{E}-03$ & $2.18 \mathrm{E}=05$ & $2.18 \mathrm{E} \div 06$ \\
\hline${ }^{236} \mathrm{U}$ & $251 \mathrm{E}-03$ & 4.39E-05 & $4.39 \mathrm{E}=06$ \\
\hline${ }^{237} \mathrm{~Np}$ & $1.03 \mathrm{E}-01$ & $2.17 \mathrm{E}-03$ & $2.17 \mathrm{E}-04$ \\
\hline
\end{tabular}

CT -8 a 
Table 8. Tank 241-AX-102 Radiological Waste Residual ${ }^{\text {(forma } 7 \text { y known as) }}$ Inventory Following Retrieval (page 2 of 2)

\begin{tabular}{|l|c|c|c|}
\hline Residual Waste (Ci) & Case I & Case II & Case III \\
\hline Decay Date & $12 / 31 / 99$ & $12 / 31 / 99$ & $12 / 31 / 99$ \\
\hline${ }^{238} \mathrm{pu}$ & $6.06 \mathrm{E}+01$ & $2.33 \mathrm{E}+01$ & $2.33 \mathrm{E}+00$ \\
\hline${ }^{238} \mathrm{U}$ & $9.77 \mathrm{E}-02$ & $4.27 \mathrm{E}-04$ & $4.27 \mathrm{E}-05$ \\
\hline${ }^{239} \mathrm{Pu}$ & $4.14 \mathrm{E}+02$ & $1.57 \mathrm{E}+02$ & $1.57 \mathrm{E}+01$ \\
\hline${ }^{240} \mathrm{Pu}$ & $1.48 \mathrm{E}+02$ & $5.66 \mathrm{E}+01$ & $5.66 \mathrm{E}+00$ \\
\hline${ }^{2391240} \mathrm{Pu}$ & $5.62 \mathrm{E}+02$ & $2.14 \mathrm{E}+02$ & $2.14 \mathrm{E}+01$ \\
\hline${ }^{241} \mathrm{Am}$ & $1.33 \mathrm{E}+03$ & $5.08 \mathrm{E}+02$ & $5.08 \mathrm{E}+01$ \\
\hline${ }^{241} \mathrm{Pu}$ & $4.19 \mathrm{E}+03$ & $1.61 \mathrm{E}+03$ & $1.61 \mathrm{E}+02$ \\
\hline${ }^{242} \mathrm{Cm}$ & $1.78 \mathrm{E}+00$ & $6.77 \mathrm{E}-01$ & $6.77 \mathrm{E}-02$ \\
\hline${ }^{242} \mathrm{mAm}$ & $\mathrm{NR}$ & NR & NR \\
\hline${ }^{242} \mathrm{Pu}$ & $3.04 \mathrm{E}-02$ & $1.17 \mathrm{E}-02$ & $1.17 \mathrm{E}-03$ \\
\hline${ }^{243} \mathrm{Am}$ & $1.48 \mathrm{E}-01$ & $5.69 \mathrm{E}-02$ & $5.69 \mathrm{E}-03$ \\
\hline${ }^{243} \mathrm{Cm}$ & $2.18 \mathrm{E}-01$ & $8.31 \mathrm{E}-02$ & $8.31 \mathrm{E}-03$ \\
\hline${ }^{244} \mathrm{Cm}$ & $8.95 \mathrm{E}+00$ & $3.44 \mathrm{E}+00$ & $3.44 \mathrm{E}-01$ \\
\hline Total & $3.97 \mathrm{E}+05$ & $1.27 \mathrm{E}+05$ & $1.27 \mathrm{E}+04$ \\
\hline
\end{tabular}


Table 9. Retrieval Scenario Product Solution Non radiological Analyte Concentrations (page 1 of 2)

\begin{tabular}{|c|c|c|c|}
\hline Limiting Vol (L) & 55,115 & 264,884 & 413,948 \\
\hline Sludge [Solids Basis (L)] & 0 & 264,884 & 413,948 \\
\hline Saltcake [Na Basis (L)] & 55,115 & 252,952 & 262,438 \\
\hline Solution Concentrations (M) & Case I & Case II & Case III \\
\hline $\mathrm{Ag}$ & NR & NR & $\mathrm{NR}$ \\
\hline $\mathrm{Al}$ & $3.11 \mathrm{E}-01$ & $3.87 \mathrm{E}-01$ & $2.88 \mathrm{E}-01$ \\
\hline As & $\mathrm{NR}$ & NR & $\mathrm{NR}$ \\
\hline $\mathrm{B}$ & $3.33 \mathrm{E}-01$ & $2.97 \mathrm{E}-01$ & $1.90 \mathrm{E}-01$ \\
\hline $\mathrm{Ba}$ & NR. & NR & NR. \\
\hline $\mathrm{Bi}$ & $6.61 \mathrm{E}-04$ & $5.89 \mathrm{E}-04$ & $3.77 \mathrm{E}-04$ \\
\hline $\mathrm{Ca}$ & $8.84 \mathrm{E}-03$ & 2.01E-02 & $1.73 \mathrm{E}-02$ \\
\hline $\mathrm{Cd}$ & $9.01 \mathrm{E}-06$ & $8.03 \mathrm{E}-06$ & $5.14 \mathrm{E}-06$ \\
\hline 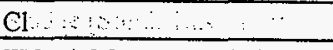 & $3.53 \mathrm{E}-02$ & $3.35 \mathrm{E}-02$ & $2.22 \mathrm{E}-02$ \\
\hline $\mathrm{IIC}$ as $\mathrm{CO}_{3}$ & $6.62 \mathrm{E}-01$ & $6.18 \mathrm{E}-01$ & 4.05E-01 \\
\hline $\mathrm{Cr} \quad$ & $1.25 \mathrm{E}-02$ & $1.14 \mathrm{E}-02$ & $7.41 \mathrm{E}-03$ \\
\hline $\mathrm{Cu}$ & $1.99 \mathrm{E}-03$ & $1.77 \mathrm{E}-03$ & $1.13 \mathrm{E}-03$ \\
\hline $\mathrm{F}$ : & $3.95 \mathrm{E}-02$ & $3.52 \mathrm{E}-02$ & $2.25 \mathrm{E}-02$ \\
\hline $\mathrm{Fe}$ & $2.46 \mathrm{E}-02$ & $1.79 E-01$ & $1.71 \mathrm{E}-01$ \\
\hline $\mathrm{Hg}$ & $5.05 \mathrm{E}-06$ & $4.50 \mathrm{E}-06$ & $2.88 \mathrm{E}-06$ \\
\hline $\mathrm{K}$ & $2.08 \mathrm{E}-02$ & $1.90 \mathrm{E}-02$ & $1.23 \mathrm{E}-02$ \\
\hline $\mathrm{La}$ & $1.38 \mathrm{E}-05$ & 1.23E-05 & $7.86 \mathrm{E}-06$ \\
\hline $\mathrm{Mg}$ & $5.51 \mathrm{E}-03$ & $4.91 \mathrm{E}-03$ & $3: 14 \mathrm{E}-03$ \\
\hline $\mathrm{Mn}$ & $4.70 \mathrm{E}-03$ & $1.76 \mathrm{E}-02$ & $1.61 \mathrm{E}-02$ \\
\hline $\mathrm{Na}$ & $5.00 \mathrm{E}+00$ & $4.77 \mathrm{E}+00$ & $3.17 E+00$ \\
\hline $\mathrm{Ni} \ldots$ & $3.59 \mathrm{E}-03$ & $8.83 \mathrm{E}-03$ & $7.68 \mathrm{E}-03$ \\
\hline $\mathrm{NO}_{2}$. & $6.18 \mathrm{E}-01$ & $5.80 \mathrm{E}-01$ & $3.82 \mathrm{E}-01$ \\
\hline $\mathrm{NO}_{2}$ & $1.31 \mathrm{E}+00$ & $1.20 \mathrm{E}+00$ & $7.83 \mathrm{E}-01$ \\
\hline $\mathrm{OH}$ & $3.64 \mathrm{E}+00$ & $3.71 \mathrm{E}+00$ & $2.54 \mathrm{E}+00$ \\
\hline $\mathrm{Pb}$ & $8.00 \mathrm{E}-04$ & $7.14 \mathrm{E}-04$ & $4.57 \mathrm{E}-04$ \\
\hline $\mathrm{P}$ as $\mathrm{PO}_{4}$ & $2.52 \mathrm{E}-02$ & $2.40 \mathrm{E}-02$ & $1.59 \mathrm{E}-02$ \\
\hline$P$ & $5.17 \mathrm{E}-02$ & $4.63 \mathrm{E}-02$ & $2.97 \mathrm{E}-02$ \\
\hline $\mathrm{Se}$ & $\mathrm{NR}$ & $\mathrm{NR}$ & $\mathrm{NR}$ \\
\hline Si as $\mathrm{SiO}_{3}$ & $1.52 \mathrm{E}-02$ & $6.01 E-02$ & $5.52 \mathrm{E}-02$ \\
\hline $\mathrm{S}_{\mathrm{SSO}} \mathrm{SO}_{4}$ & $1.18 \mathrm{E}-01$ & $1.07 \mathrm{E}-01$ & $6.93 \mathrm{E}-02$ \\
\hline $\mathrm{S}$ & $.1 .92 \mathrm{E}-02$ & $1.84 \mathrm{E}-02$ & $1.23 \mathrm{E}-02$ \\
\hline$S r$ & $5.29 \mathrm{E}-06$ & $3.51 \mathrm{E}-03$ & $3.51 \mathrm{E}-03$ \\
\hline TOC. & $1.15 \mathrm{E}+00$ & $1.03 \mathrm{E}+00$ & $6.61 \mathrm{E}-01$ \\
\hline Total U & $6.72 \mathrm{E}-03$ & $6.39 \mathrm{E}-03$ & $4.24 \mathrm{E}-03$ \\
\hline
\end{tabular}


Table 9. Retrieval Scenario Product Solution Nonradiological Analyte Concentrations (page 2 of 2)

\begin{tabular}{|l|r|c|c|}
\hline Limiting Vol (L) & 55,115 & 264,884 & 413,948 \\
\hline Sludge [Solids Basis (L)] & 0 & 264,884 & 413,948 \\
\hline Saltcake [Na Basis (L)] & 55,115 & 252,952 & $262 ; 438$ \\
\hline Solution Concentrations (M) & Case I & Case II & Case III \\
\hline $\mathrm{Zn}$ & $6.85 \mathrm{E}-06$ & $2.66 \mathrm{E}-04$ & $2.63 \mathrm{E}-04$ \\
\hline $\mathrm{Zr}$ & $6.24 \mathrm{E}-05$ & $5.56 \mathrm{E}-05$ & $3.56 \mathrm{E}-05$ \\
\hline EDTA & $1.43 \mathrm{E}-02$ & $1.28 \mathrm{E}-02$ & $8.16 \mathrm{E}-03$ \\
\hline $\mathrm{NH}_{3}$ & $\mathrm{NR}$ & $\mathrm{NR}$ & $\mathrm{NR}$ \\
\hline $\mathrm{Cr}^{+6}$ & $\mathrm{NR}$ & $\mathrm{NR}$ & NR \\
\hline $\mathrm{CN}$ & $5.59 \mathrm{E}+00$ & $8.05 \mathrm{E}+00$ & $6.25 \mathrm{E}+00$ \\
\hline $\mathrm{H}_{2} \mathrm{O}$ & 0.01 & 0.01 & 0.00 \\
\hline $\mathrm{Retrieval} \mathrm{H}_{2} \mathrm{O}$ & 32.37 & 31.47 & 38.89 \\
\hline
\end{tabular}

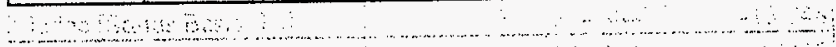


Table 10. Retrieval Scenario Product Solution Radiological

(formally known as) Analyte Concentrations (page 1 of 2)

\begin{tabular}{|c|c|c|c|}
\hline Solution Concentrations $(\mathrm{Ci} / \mathrm{L})$ & Case I & Case II & Case III \\
\hline Decay Date & $12 / 31 / 99$ & $12 / 31 / 99$ & $12 / 31 / 99$ \\
\hline 3 & $1.33 \mathrm{E}-04$ & $1.21 \mathrm{E}-04$ & $7.81 \mathrm{E}-05$ \\
\hline${ }^{14} \mathrm{C}$ & $2.05 \mathrm{E}-05$ & $1.88 \mathrm{E}-05$ & $1.23 \mathrm{E}-05$ \\
\hline${ }^{59} \mathrm{Ni}$ & $1.20 \mathrm{E}-06$ & $4.05 \mathrm{E}-06$ & $3.66 \mathrm{E}-06$ \\
\hline${ }^{60} \mathrm{CO}$ & $2.53 \mathrm{E}-05$ & $2.40 \mathrm{E}-05$ & $1.59 \mathrm{E}-05$ \\
\hline${ }^{63} \mathrm{Ni}$ & 1.19E-04 & $4.15 \mathrm{E}-04$ & $3.77 \mathrm{E}-04$ \\
\hline${ }^{79} \mathrm{Se}$ & $2.03 \mathrm{E}-06$ & $1.30 \mathrm{E}-05$ & $1.23 \mathrm{E}-05$ \\
\hline${ }^{90} \mathrm{Sr}$ & $6.10 \mathrm{E}-02$ & $3.68 \mathrm{E}-01$ & $3.48 \mathrm{E}-01$ \\
\hline${ }^{90} \mathrm{Y}$ & $6.10 \mathrm{E}-02$ & $3.68 \mathrm{E}-01$ & $3.48 \mathrm{E}-01$ \\
\hline${ }^{93} \mathrm{mNb}$ & $7.20 \mathrm{E}-06$ & $3.87 \mathrm{E}-05$ & $3.64 \mathrm{E}-05$ \\
\hline${ }^{93} \mathrm{Zr}$ & $1.00 \mathrm{E}-05$ & 5.77E-05 & $5.45 \mathrm{E}-05$ \\
\hline${ }^{99} \mathrm{Tc}:$ & $1.52 \mathrm{E}-04$ & $1.40 \mathrm{E}-04$ & $9.08 \mathrm{E}-05$ \\
\hline${ }^{106} \mathrm{Ru}$ & $4.36 \mathrm{E}-09$ & $1.36 \mathrm{E}-06$ & $1.36 \mathrm{E}-06$ \\
\hline${ }^{113} \mathrm{mCd}$ & 5.42E-05 & 2.92E-04 & $2.75 \mathrm{E}-04$ \\
\hline${ }^{125} \mathrm{Sb}$ & 1.14E-04 & $1.10 \mathrm{E}-04$ & $7.39 \mathrm{E}-05$ \\
\hline${ }^{126} \mathrm{Sn}$ & $3.06 \mathrm{E}-06$ & $2.04 \mathrm{E}-05$ & $1.94 \mathrm{E}-05$ \\
\hline${ }^{129} \mathrm{I}$ & $2.94 \mathrm{E}-07$ & $2.70 \mathrm{E}-07$ & $1.76 \mathrm{E}-07$ \\
\hline${ }^{134} \mathrm{Cs}$ & $2.00 \mathrm{E}-06$ & 1.86E-06 & $1.21 \mathrm{E}-06$ \\
\hline${ }^{133} \mathrm{Cs}$ & NR & $\mathrm{NR}$ & $\mathrm{NR}$ \\
\hline${ }^{137} \mathrm{Cs}$ & $1.27 \mathrm{E}-01$ & $1.56 \mathrm{E}-01$ & $1.16 \mathrm{E}-01$ \\
\hline${ }^{137} \mathrm{mBa}$ & $1.20 \mathrm{E}-01$ & $1.48 \mathrm{E}-01$ & $1.09 \mathrm{E}-01$ \\
\hline${ }^{151} \mathrm{Sm}$ & 7.14E-03 & $3.85 \mathrm{E}-02$ & $3.63 \mathrm{E}-02$ \\
\hline${ }^{152} \mathrm{Eu}$ & $2.64 \mathrm{E}-06$ & $4.97 \mathrm{E}-05$ & $4.89 \mathrm{E}-05$ \\
\hline${ }^{154} \mathrm{Eu}$ & 3.95E-04 & $3.98 \mathrm{E}-03$ & $3.85 \mathrm{E}-03$ \\
\hline${ }^{155} \mathrm{Eu}$ & $1.56 \mathrm{E}-04$ & $2.44 \mathrm{E}-03$ & $2.39 \mathrm{E}-03$ \\
\hline${ }^{226} \mathrm{Ra}$ & $7.96 \mathrm{E}-11$ & $5.70 \mathrm{E}-10$ & $5.45 \mathrm{E}-10$ \\
\hline${ }^{227} \mathrm{AC}$ & $4.96 \mathrm{E}-10$ & $2.81 \mathrm{E}-09$ & $2.65 \mathrm{E}-09$ \\
\hline${ }^{228} \mathrm{Ra}$ & $1.61 \mathrm{E}-07$ & $1.43 \mathrm{E}-07$ & $9.16 \mathrm{E}-08$ \\
\hline${ }^{229} \mathrm{Th}$ & 3.73E-09 & 3.33E-09 & $2.13 \mathrm{E}-09$ \\
\hline${ }^{231} \mathrm{~Pa}$ & $2.37 \mathrm{E}-09$ & $2.18 \mathrm{E}-09$ & $1.42 \mathrm{E}-09$ \\
\hline${ }^{232} \mathrm{Th}$ & $1.63 \mathrm{E}-08$ & $1.46 \mathrm{E}-08$ & $9.32 \mathrm{E}-09$ \\
\hline${ }^{232} \mathrm{U}$ & $5.34 \mathrm{E}-07$ & $4.76 \mathrm{E}-07$ & $3.04 \mathrm{E}-07$ \\
\hline${ }^{233} \mathrm{U}$ & $2.04 \mathrm{E}-06$ & $1.82 \mathrm{E}-06$ & $1.16 \mathrm{E}-06$ \\
\hline${ }^{234} \mathrm{U}$. & $4.13 \mathrm{E}-07$ & $3.72 \mathrm{E}-07$ & $2.39 \mathrm{E}-07$ \\
\hline${ }^{235} \mathrm{U}$ & $1.65 \mathrm{E}-08$ & $1.49 \mathrm{E}-08$ & $9.55 \mathrm{E}-09$ \\
\hline${ }^{236} \mathrm{U}$ & $1.32 \mathrm{E}-08$ & $1.20 \mathrm{E}-08$ & $7.80 \mathrm{E}-09$ \\
\hline${ }^{237} \mathrm{~Np}$ & $5.38 \mathrm{E}-07$ & $4.93 \mathrm{E}-07$ & $3.20 \mathrm{E}-07$ \\
\hline
\end{tabular}


Table 10. Retrieval Scenario Product Solution Radiological

Analyte Concentrations (page 2 of 2)

\begin{tabular}{|l|c|c|c|}
\hline Solution Concentrations (Ci/L) & Case I & Case II & Case III \\
\hline Decay Date & $12 / 31 / 99$ & $12 / 31 / 99$ & $12 / 31 / 99$ \\
\hline${ }^{238} \mathrm{Pu}$ & $8.13 \mathrm{E}-07$ & $1.41 \mathrm{E}-04$ & $1.41 \mathrm{E}-04$ \\
\hline${ }^{238} \mathrm{U}$ & $5.34 \mathrm{E}-07$ & $4.78 \mathrm{E}-07$ & $3.07 \mathrm{E}-07$ \\
\hline${ }^{239} \mathrm{Pu}$ & $2.64 \mathrm{E}-05$ & $9.74 \mathrm{E}-04$ & $9.65 \mathrm{E}-04$ \\
\hline${ }^{240} \mathrm{Pu}$ & $4.57 \mathrm{E}-06$ & $3.46 \mathrm{E}-04$ & $3.44 \mathrm{E}-04$ \\
\hline${ }^{2391240} \mathrm{Pu}$ & $3.10 \mathrm{E}-05$ & $1.32 \mathrm{E}-03$ & $1.31 \mathrm{E}-03$ \\
\hline${ }^{241} \mathrm{Am}$ & $3.35 \mathrm{E}-05$ & $3.10 \mathrm{E}-03$ & $3.09 \mathrm{E}-03$ \\
\hline${ }^{241} \mathrm{Pu}$ & $5.59 \mathrm{E}-05$ & $9.76 \mathrm{E}-03$ & $9.74 \mathrm{E}-03$ \\
\hline${ }^{242} \mathrm{mAm}$ & $9.78 \mathrm{E}-08$ & $4.18 \mathrm{E}-06$ & $4.14 \mathrm{E}-06$ \\
\hline${ }^{242} \mathrm{Pu}$ & $\mathrm{NR}$ & NR & NR \\
\hline${ }^{243} \mathrm{Am}$ & $3.09 \mathrm{E}-10$ & $7.07 \mathrm{E}-08$ & $7.06 \mathrm{E}-08$ \\
\hline${ }^{243} \mathrm{Cm}$ & $1.29 \mathrm{E}-09$ & $3.45 \mathrm{E}-07$ & $3.45 \mathrm{E}-07$ \\
\hline${ }^{244} \mathrm{Cm}$ & $9.40 \mathrm{E}-09$ & $5.10 \mathrm{E}-07$ & $5.07 \mathrm{E}-07$ \\
\hline
\end{tabular}


(formally known as)

Table 11. Tank 241-AX-102 Retrieval Scenario Non radiological Constituent Leakage Estimate (page 1 of 2)

\begin{tabular}{|c|c|c|c|c|c|c|}
\hline $\begin{array}{l}\text { Release } \\
\text { Volume (L) }\end{array}$ & 30,283 & 30,283 & 30,283 & 55,115 & 151,413 & 151,413 \\
\hline Analyte $(\mathrm{kg})$ & Case I & Case II & Case III & Case I & Case II & Case III \\
\hline $\mathrm{Ag}$ & $\mathrm{NR}$ & NR & $\mathrm{NR}$ & & $10 \Omega$ & \\
\hline $\mathrm{A} \mathrm{I}^{\mathrm{B}}$ & $2.54 \mathrm{E}+02$ & $3.17 \mathrm{E}+02$ & $2.35 \mathrm{E}+02$ & $52 \mathrm{E}+02$ & $1.58 \mathrm{E}+03$ & $8 \mathrm{E}+03$ \\
\hline As & $\mathrm{NR}$ & NR & $\mathrm{NR}$ & $\mathrm{NR}$ & $\mathrm{NR}$ & NR \\
\hline $\mathrm{B}$ & $1.09 \mathrm{E}+02$ & $9.73 \mathrm{E}+01$ & $6.23 \mathrm{E}+01$ & $98 \mathrm{E}+02$ & $86 \mathrm{E} \div 02$ & $12 \mathrm{E}+02$ \\
\hline $\mathrm{Ba}$ & $\mathrm{NR}$ & NR & $\mathrm{NR}$ & NR & 87 & $\sqrt{R}$ \\
\hline $\mathrm{Bi}$ & $4.18 \mathrm{E}+00$ & $3.73 \mathrm{E}+00$ & $2.38 \mathrm{E}+00$ & $61 \mathrm{E}+00$ & $1.86 \mathrm{E}+01$ & $\mathrm{E}+01$ \\
\hline $\mathrm{Ca}$ & $1.07 \mathrm{E}+01$ & $2.44 \mathrm{E}+01$ & $2.10 \mathrm{E}+01$ & $1.95 \mathrm{E}+01$ & $1.22 \mathrm{E}+02$ & $.05 \mathrm{E}+02$ \\
\hline $\mathrm{Cd}$ & 3.07E-02 & $73 \mathrm{E}-02$ & $1.75 \mathrm{E}-02$ & -02 & 1.3 & -02 \\
\hline $\mathrm{Cl}$ & $3.79 \mathrm{E}+01$ & $3.60 \mathrm{E} \div 01$ & $2.38 \mathrm{E}+01$ & +01 & +02 & +02 \\
\hline TIC a & $1.20 \mathrm{E}+03$ & $1.12 \mathrm{E}+03$ & $7.36 \mathrm{E}+02$ & $2.19 \mathrm{E}+03$ & $5.61 \mathrm{E}+03$ & +03 \\
\hline $\mathrm{Cr}$ & $1.97 \mathrm{E}+01$ & $1.80 \mathrm{E}+01$ & $1.17 \mathrm{E}+01$ & $3.58 \mathrm{E}+01$ & $8.99 \mathrm{E}+01$ & +01 \\
\hline $\mathrm{Cu}$ & $3.82 \mathrm{E}+00$ & $3.41 E+00$ & $2.18 \mathrm{E}+00$ & $6 \mathrm{E}+00$ & $1.70 \mathrm{E}+01$ & +01 \\
\hline $\mathrm{F}$ & $2.27 E+01$ & $2.03 \mathrm{E}+01$ & $1.30 \mathrm{E}+01$ & $4.14 E+01$ & $1.01 \mathrm{E}+02$ & $E+01$ \\
\hline $\mathrm{Fe}$ & $4.17 \mathrm{E}+01$ & $3.02 \mathrm{E}+02$ & $2.89 \mathrm{E}+02$ & $7.58 \mathrm{E}+01$ & $1.51 \mathrm{E}+03$ & +03 \\
\hline $\mathrm{Hg}$ & $3.07 \mathrm{E}-02$ & & $1.75 \mathrm{E}-02$ & & $=01$ & \\
\hline $\mathrm{K}$ & $2.46 \mathrm{E}+01$ & $2.25 \mathrm{E}+01$ & $1.46 \mathrm{E}+01$ & $4.48 \mathrm{E}+01$ & $1.12 \mathrm{E}+02$ & +01 \\
\hline $\mathrm{La}$ & $5.80 \mathrm{E}-02$ & E-02 & $3.31 \mathrm{E}-02$ & 1. & -01 & -01 \\
\hline $\mathrm{Mg}$ & $4.05 \mathrm{E}+00$ & $+\infty$ & $2.31 \mathrm{E}+00$ & $+\infty$ & +01 & +01 \\
\hline $\mathrm{Mn}$ & $7.83 E+00$ & $2.92 \mathrm{E}+01$ & $2.67 \mathrm{E}+01$ & +01 & +02 & +02 \\
\hline $\mathrm{Na}$ & $3.48 \mathrm{E}+03$ & $3.32 \mathrm{E}+03$ & $2.21 \mathrm{E}+03$ & +03 & $1.66 \mathrm{E}+04$ & +04 \\
\hline $\mathrm{Ni}$ & $6.37 \mathrm{E}+00$ & $1.57 \mathrm{E}+01$ & $1.36 \mathrm{E}+01$ & +01. & $7.85 \mathrm{E}+01$ & $E+01$ \\
\hline $\mathrm{NO}$ & $8.60 \mathrm{E}+02$ & $8.08 \mathrm{E}+02$ & $5.32 \mathrm{E}+02$ & +03 & $4.04 \mathrm{E}+03$ & $\mathrm{E}+03$ \\
\hline $\mathrm{NO}_{3}$ & $2.46 \mathrm{E}+03$ & $2.26 \mathrm{E}+03$ & $1.47 \mathrm{E}+03$ & +03 & +04 & $E+03$ \\
\hline $\mathrm{OH}$ & $1.87 \mathrm{E}+03$ & $1.91 \mathrm{E}+03$ & $1.31 \mathrm{E}+03$ & $3.41 E+03$ & $9.55 \mathrm{E}+03$ & $\mathrm{E}+03$ \\
\hline $\mathrm{Pb}$ & $5.02 \mathrm{E}+00$ & $4.48 \mathrm{E}+00$ & $2.87 \mathrm{E}+00$ & +00 & $2.24 \mathrm{E}+01$ & $E+01$ \\
\hline $\mathrm{P}$ as & $7.25 \mathrm{E}+01$ & $6.89 \mathrm{E}+01$ & $4.56 \mathrm{E}+01$ & $1.32 \mathrm{E}+02$ & $3.44 \mathrm{E}+02$ & $\mathrm{E}+02$ \\
\hline P & $4.84 \mathrm{E}+01$ & $4.34 \mathrm{E}+01$ & $2.79 \mathrm{E}+01$ & $8.82 \mathrm{E}+01$ & $2.17 \mathrm{E}+02$ & $1.39 \mathrm{E}+02$ \\
\hline $\mathrm{Se}$ & $N R$ & NR & NR & NR & NR. & $\mathrm{NR}$ \\
\hline Sias & $3.50 \mathrm{E}+01$ & $1.38 \mathrm{E}+02$ & $1.27 \mathrm{E}+02$ & $6.37 \mathrm{E}+01$ & $6.92 \mathrm{E}+02$ & $6.36 \mathrm{E}+02$ \\
\hline & $3.43 E+02$ & $3.12 E+02$ & $2.02 \mathrm{E}+02$ & $6.24 \mathrm{E}+02$ & $1.56 \mathrm{E}+03$ & $1.01 \mathrm{E}+03$ \\
\hline S: & $1.86 \mathrm{E}+01$ & $1.79 \mathrm{E}+01$ & $1.19 \mathrm{E}+01$ & $3.38 \mathrm{E}+01$ & $8.93 E+01$ & $5.95 \mathrm{E}+01$ \\
\hline $\mathrm{Sr}$ & $1.40 \mathrm{E}-02$ & $9.32 \mathrm{E}+00$ & $9.31 \mathrm{E}+00$ & $2.55 \mathrm{E}-02$ & $4.66 \mathrm{E}+01$ & $4.66 \mathrm{E}+01$ \\
\hline TOC & $4.18 \mathrm{E}+02$ & $3.75 E+02$ & $2.40 \mathrm{E}+02$ & $7.62 E+02$ & $1.87 \mathrm{E}+03$ & $1.20 \mathrm{E}+03$ \\
\hline Total & $4.84 \mathrm{E}+01$ & $4.61 \mathrm{E}+01$ & $3.05 \mathrm{E}+01$ & $8.82 \mathrm{E}+01$ & $2.30 \mathrm{E}+02$ & $1.53 \mathrm{E}+02$ \\
\hline & $1.36 \mathrm{E}-02$ & $5.26 \mathrm{E}-01$ & $5.21 \mathrm{E}-01$ & $2: 47 \mathrm{E}-02$ & $2.63 E+00$ & $2.61 \mathrm{E}+00$ \\
\hline
\end{tabular}


HNF-SD-HTI-TI-001; REV. 0

SESC-EN-RPT-002, Rev. 1

(formatly known as)

Table 11. Tank 241-AX-102 Retrieval Scenario Nonradiological

Constituent Leakage Estimate (page 2 of 2)

\begin{tabular}{|l|c|c|c|c|c|c|}
\hline $\begin{array}{l}\text { Release } \\
\text { Volume (L) }\end{array}$ & 30,283 & 30,283 & 30,283 & 55,115 & 151,413 & 151,413 \\
\hline Analyte (kg) & Case I & Case II & Case III & Case I & Case II & Case III \\
\hline $\mathrm{Zr}$ & $1.72 \mathrm{E}-01$ & $1.54 \mathrm{E}-01$ & $9.83 \mathrm{E}-02$ & $3.14 \mathrm{E}-01$ & $7.68 \mathrm{E}-01$ & $4.91 \mathrm{E}-01$ \\
\hline $\mathrm{EDTA}$ & $1.27 \mathrm{E}+02$ & $1.13 \mathrm{E}+02$ & $7.22 \mathrm{E}+01$ & $2.30 \mathrm{E}+02$ & $5.64 \mathrm{E}+02$ & $3.61 \mathrm{E}+02$ \\
\hline $\mathrm{NH}_{3}$ & $\mathrm{NR}$ & $\mathrm{NR}$ & $\mathrm{NR}$ & $\mathrm{NR}$ & $\mathrm{NR}$ & $\mathrm{NR}$ \\
\hline $\mathrm{Cr}$ & $\mathrm{NR}$ & $\mathrm{NR}$ & $\mathrm{NR}$ & $\mathrm{NR}$ & $\mathrm{NR}$ & $\mathrm{NR}$ \\
\hline $\mathrm{CN}$ & $4.40 \mathrm{E}+03$ & $6.34 \mathrm{E}+03$ & $4.93 \mathrm{E}+03$ & $8.02 \mathrm{E}+03$ & $3.17 \mathrm{E}+04$ & $2.46 \mathrm{E}+04$ \\
\hline $\mathrm{H}_{2} \mathrm{O}$ & $4.04 \mathrm{E}+00$ & $3.66 \mathrm{E}+00$ & $2.36 \mathrm{E}+00$ & $7.35 \mathrm{E}+00$ & $1.83 \mathrm{E}+01$ & $1.18 \mathrm{E}+01$ \\
\hline $\begin{array}{l}\text { Retrieval } \\
\text { water }\end{array}$ & $1.77 \mathrm{E}+04$ & $1.72 \mathrm{E}+04$ & $2.12 \mathrm{E}+04$ & $3.21 \mathrm{E}+04$ & $8.58 \mathrm{E}+04$ & $1.06 \mathrm{E}+05$ \\
\hline Total $(\mathrm{kg})$ & $3.32 \mathrm{E}+04$ & $3.46 \mathrm{E}+04$ & $3.37 \mathrm{E}+04$ & $6.05 \mathrm{E}+04$ & $1.73 \mathrm{E}+05$ & $1.68 \mathrm{E}+05$ \\
\hline
\end{tabular}


HNF-SD-HTI-TI-001, REV. $0^{\circ}$

SESC-EN-RPT-002, Rev. 1

(formally known as)

Table 12. Tank 241-AX-102 Retrieval Scenario Radiological Constituent Leakage Estimate (page 1 of 2)

\begin{tabular}{|c|c|c|c|c|c|c|}
\hline $\begin{array}{l}\text { Release } \\
\text { Volume (L) }\end{array}$ & 30,283 & 30,283 & 30,283 & 55,115 & 151,413 & 151,413 \\
\hline Analyte (Ci) & Case I & Case II & Case III & Case I & Case II & Case III \\
\hline Decay Date & $12 / 31 / 99$ & $12 / 31 / 99$ & $12 / 31 / 99$ & $12 / 31 / 99$ & $12 / 31 / 99$ & $12 / 31 / 99$ \\
\hline $\mathrm{H}$ & +00 & $3.66 \mathrm{E}+00$ & $2.36 \mathrm{E}+00$ & $7.35 \mathrm{E}+00$ & $1.83 \mathrm{E}+01$ & $1.18 \mathrm{E}+01$ \\
\hline${ }^{14} \mathrm{C}$ & $6.20 \mathrm{E}-01$ & $5.71 \mathrm{E}-01$ & $3.72 \mathrm{E}-01$ & $1.13 \mathrm{E}+00$ & $2.85 \mathrm{E}+00$ & $1.86 \mathrm{E}+00$ \\
\hline${ }^{5} \mathrm{Ni}$ & $3.64 \mathrm{E}-02$ & $1.23 \mathrm{E}-01$ & $1.11 \mathrm{E}-01$ & $6.63 \mathrm{E}-02$ & $6.13 \mathrm{E}-01$ & $5.54 \mathrm{E}-0.1$ \\
\hline${ }^{60} \mathrm{Co}$ & $7.67 \mathrm{E}-01$ & $7.28 \mathrm{E}-01$ & $4.82 \mathrm{E}-01$ & $1.40 \mathrm{E}+00$ & $3.64 \mathrm{E}+00$ & $2.41 \mathrm{E} \div 00$ \\
\hline${ }^{63} \mathrm{Ni}$ & $3.59 \mathrm{E}+00$ & $1.26 \mathrm{E}+01$ & $1.14 \mathrm{E}+01$ & $6.54 \mathrm{E}+00$ & $6.28 \mathrm{E}+01$ & $5.70 \mathrm{E}+01$ \\
\hline${ }^{79} \mathrm{Se}$ & 6.1 & $3.93 \mathrm{E}-01$ & $3.73 \mathrm{E}-01$ & $1.12 \mathrm{E}-01$ & $1.97 \mathrm{E}+00$ & $1.87 \mathrm{E}+00$ \\
\hline${ }^{90} \mathrm{Sr}$ & $1.85 E+03$ & $1.11 \mathrm{E}+04$ & $1.05 \mathrm{E}+04$ & $\mathrm{E}+03$ & $5.57 \mathrm{E}+04$ & $5.27 \mathrm{E}+04$ \\
\hline${ }^{90} \mathrm{Y}$ & 1.85 & $1.11 \mathrm{E}+04$ & $1.05 \mathrm{E}+04$ & $8+03$ & +04 & $5.27 \mathrm{E}+04$ \\
\hline${ }^{3} \mathrm{mNb}$ & $2.18 \mathrm{E}-01$ & $17 \mathrm{E}+00$ & +00 & -01. & +00 & $5.51 \mathrm{E}+00$ \\
\hline${ }^{93} \mathrm{Zr}:$ & -01 & $1.75 \mathrm{E}+00$ & $1.65 \mathrm{E}+00$ & $5.51 \mathrm{E}-01$ & $8.73 \mathrm{E}+00$ & $8.25 \mathrm{E}+00$ \\
\hline${ }^{99} \mathrm{Tc}$ & $4.60 \mathrm{E}+00$ & $4.23 \mathrm{E}+00$ & $2.75 \mathrm{E}+00$ & $8+00$ & +01 & $8+01$ \\
\hline${ }^{106} \mathrm{Ru}$ & -04 & $\mathrm{E}-02$ & -02 & E-04 & $2.06 \mathrm{E}-01$ & $\mathrm{E}-01$ \\
\hline${ }^{113} \mathrm{mCd}$ & $1.64 \mathrm{E}+00$ & $8.85 E+00$ & $8.32 \mathrm{E}+00$ & $2.99 \mathrm{E}+00$ & $4.42 \mathrm{E}+01$ & $8+01$ \\
\hline${ }^{125} \mathrm{Sb}$ & $3.44 E+00$ & $3.34 \mathrm{E}+00$ & $2.24 \mathrm{E}+00$ & $6.26 \mathrm{E}+00$ & $1.67 \mathrm{E}+01$ & $8+01$ \\
\hline${ }^{126} \mathrm{Sn}$ & $9.27 \mathrm{E}-02$ & $6.19 \mathrm{E}-01$ & $5.89 \mathrm{E}-01$ & $1.69 \mathrm{E}-01$ & $3.09 \mathrm{E}+00$ & $2.94 \mathrm{E}+00$ \\
\hline${ }^{129} \mathrm{I}$ & $8.90 \mathrm{E}-03$ & $8.17 \mathrm{E}-03$ & $5.32 \mathrm{E}-03$ & $1.62 \mathrm{E}-02$ & -02 & $2.66 \mathrm{E}-02$ \\
\hline${ }^{134} \mathrm{Cs}$ & 6.07E-02 & $5.62 \mathrm{E}-02$ & $\mathrm{E}-02$ & $\mathrm{E}-01$ & $2.81 \mathrm{E}-01$ & $1.84 \mathrm{E}-01$ \\
\hline${ }^{135} \mathrm{Cs}$ & $R$ & $\mathrm{R}$ & NR & $\mathrm{R}$ & $\mathrm{IR}$ & \\
\hline${ }^{137} \mathrm{Cs}$ & $3.84 \mathrm{E}+03$ & $4.73 E+03$ & $3.50 \mathrm{E}+03$ & $6.98 \mathrm{E}+03$ & $2.37 \mathrm{E}+04$ & $1.75 \mathrm{E}+04$ \\
\hline${ }^{137} \mathrm{mBa}$ & $3.63 \mathrm{E}+03$ & $4.48 \mathrm{E}+03$ & $3.31 \mathrm{E}+03$ & $6.60 \mathrm{E}+03$ & $2.24 \mathrm{E}+04$ & $1.66 \mathrm{E}+04$ \\
\hline${ }^{151} \mathrm{Sm}$ & $2.16 \mathrm{E}+02$ & $1.17 \mathrm{E}+03$ & $1.10 \mathrm{E}+03$ & $3.94 \mathrm{E}+02$ & $5.84 \mathrm{E}+03$ & $5.49 \mathrm{E}+03$ \\
\hline${ }^{152} \mathrm{Eu}$ & $7.99 \mathrm{E}-02$ & $1.51 \mathrm{E}+00$ & $1.48 \mathrm{E}+00$ & $1.45 \mathrm{E}-01$ & $7.53 \mathrm{E}+00$ & $7.40 \mathrm{E}+00$ \\
\hline${ }^{154} \mathrm{Eu}$ & $1.20 \mathrm{E}+01$ & $1.20 \mathrm{E}+02$ & $1.17 \mathrm{E}+02$ & $2.18 \mathrm{E}+01$ & $6.02 \mathrm{E}+02$ & $5.83 \mathrm{E}+02$ \\
\hline${ }^{155} \mathrm{Eu}$ & $4.73 \mathrm{E}+00$ & $7.38 \mathrm{E}+01$ & $7.23 \mathrm{E}+01$ & $8.61 \mathrm{E}+00$ & $3.69 E+02$ & $3.61 \mathrm{E}+02$ \\
\hline${ }^{226} \mathrm{Ra}$ & $2.41 \mathrm{E}-06$ & 05 & $1.65 \mathrm{E}-05$ & $4.39 E-06$ & $8.64 \mathrm{E}-05$ & $8.25 \mathrm{E}-05$ \\
\hline${ }^{227} \mathrm{Ac}$ & $1.50 \mathrm{E}-05$ & $8.51 \mathrm{E}-05$ & 8.03E-05 & $2.73 \mathrm{E}-05$ & $4.26 \mathrm{E}-04$ & 4.02E-04 \\
\hline${ }^{228} \mathrm{Ra}$ & $4.86 \mathrm{E}-03$ & 4.3 & $2.77 \mathrm{E}-03$ & $8.85 \mathrm{E}-03$ & $2.17 \mathrm{E}-02$ & $1.39 \mathrm{E}-02$ \\
\hline${ }^{229} \mathrm{Th}$ & $1.13 \mathrm{E}-04$ & $1.01 \mathrm{E}-04$ & $6.45 \mathrm{E}-05$ & $2.06 \mathrm{E}-04$ & $5.04 \mathrm{E}-04$ & $3.23 \mathrm{E}-04$ \\
\hline${ }^{231} \mathrm{~Pa}$ & $7.17 \mathrm{E}-05$ & $6.62 \mathrm{E}-05$ & $4.31 \mathrm{E}-05$ & $1.30 \mathrm{E}-04$ & $3.31 \mathrm{E}-0.4$ & \begin{tabular}{|l|}
$2.16 \mathrm{E}-04$ \\
\end{tabular} \\
\hline${ }^{232} \mathrm{Th}$ & $4.95 \mathrm{E}-04$ & $4.41 \mathrm{E}-04$ & 2.82E-04 & $9.01 \mathrm{E}-04$ & $2.21 \mathrm{E}-03$ & $1.41 \mathrm{E}-03$ \\
\hline${ }^{232} \mathrm{U}$ & $1.62 \mathrm{E}-02$ & $1.44 \mathrm{E}-02$ & $9.22 \mathrm{E}-03$ & $2.94 \mathrm{E}-02$ & $7.20 \mathrm{E}-02$ & $4.61 \mathrm{E}-02$ \\
\hline${ }^{233} \mathrm{U}$ & $6.18 \mathrm{E}=02$ & $5.51 \mathrm{E}-02$ & $3.53 \mathrm{E}-02$ & $1.13 \mathrm{E}-01$ & $2.76 \mathrm{E}-01$ & $1.76 \mathrm{E}-01$ \\
\hline${ }^{234} \mathrm{U}$ & $1.25 \mathrm{E}-02$ & $1.13 \mathrm{E}-02$ & $7.24 \mathrm{E}-03$ & $2.28 \mathrm{E}-02$ & $5.63 \mathrm{E}-02$ & $3.62 \mathrm{E}-02$ \\
\hline U & & $4.50 \mathrm{E}-04$ & -04 & -04 & $2.25 \mathrm{E}=03$ & \\
\hline
\end{tabular}


HNF-SD-HTI-TI-001, REV. 0

SESC-EN-RPT-002, Rev. 1

(formal1y known as)

Table 12. Tank 241-AX-102 Retrieval Scenario Radiological Constituent Leakage Estimate (page 2 of 2)

\begin{tabular}{|l|c|c|c|c|c|c|}
\hline $\begin{array}{l}\text { Release } \\
\text { Volume (L) }\end{array}$ & 30,283 & 30,283 & 30,283 & 55,115 & 151,413 & 151,413 \\
\hline Analyte (Ci) & Case I & Case II & Case III & Case I & Case II & Case III \\
\hline Decay Date & $12 / 31 / 99$ & $12 / 31 / 99$ & $12 / 31 / 99$ & $12 / 31 / 99$ & $12 / 31 / 99$ & $12 / 31 / 99$ \\
\hline${ }^{236} \mathrm{U}$ & $4.00 \mathrm{E}-04$ & $3.65 \mathrm{E}-04$ & $2.36 \mathrm{E}-04$ & $7.28 \mathrm{E}-04$ & $1.82 \mathrm{E}-03$ & $1.18 \mathrm{E}-03$ \\
\hline${ }^{237} \mathrm{~Np}$ & $1.63 \mathrm{E}-02$ & $1.49 \mathrm{E}-02$ & $9.69 \mathrm{E}-03$ & $2.96 \mathrm{E}-02$ & $7.46 \mathrm{E}-02$ & $4.84 \mathrm{E}-02$ \\
\hline${ }^{238} \mathrm{Pu}$ & $2.46 \mathrm{E}-02$ & $4.28 \mathrm{E}+00$ & $4.27 \mathrm{E}+00$ & $4.48 \mathrm{E}-02$ & $2.14 \mathrm{E}+01$ & $2.13 \mathrm{E}+01$ \\
\hline${ }^{238} \mathrm{U}$ & $1.62 \mathrm{E}-02$ & $1.45 \mathrm{E}-02$ & $9.30 \mathrm{E}-03$ & $2.94 \mathrm{E}-02$ & $7.24 \mathrm{E}-02$ & $4.65 \mathrm{E}-02$ \\
\hline${ }^{239} \mathrm{Pu}$ & $8.00 \mathrm{E}-01$ & $2.95 \mathrm{E}+01$ & $2.92 \mathrm{E}+01$ & $1.46 \mathrm{E}+00$ & $1.47 \mathrm{E}+02$ & $1.46 \mathrm{E}+02$ \\
\hline${ }^{240} \mathrm{Pu}$ & $1.39 \mathrm{E}-01$ & $1.05 \mathrm{E}+01$ & $1.04 \mathrm{E}+01$ & $2.52 \mathrm{E}-01$ & $5.23 \mathrm{E}+01$ & $5.21 \mathrm{E}+01$ \\
\hline${ }^{239240} \mathrm{Pu}$ & $9.39 \mathrm{E}-01$ & $3.99 \mathrm{E}+01$ & $3.96 \mathrm{E}+01$ & $1.71 \mathrm{E}+00$ & $2.00 \mathrm{E}+02$ & $1.98 \mathrm{E}+02$ \\
\hline${ }^{241} \mathrm{Am}$ & $1.01 \mathrm{E}+00$ & $9.38 \mathrm{E}+01$ & $9.34 \mathrm{E}+01$ & $1.85 \mathrm{E}+00$ & $4.69 \mathrm{E}+02$ & $4.67 \mathrm{E}+02$ \\
\hline${ }^{241} \mathrm{Pu}$ & $1.69 \mathrm{E}+00$ & $2.96 \mathrm{E}+02$ & $2.95 \mathrm{E}+02$ & $3.08 \mathrm{E}+00$ & $1.48 \mathrm{E}+03$ & $1.47 \mathrm{E}+03$ \\
\hline${ }^{242} \mathrm{Cm}$ & $2.96 \mathrm{E}-03$ & $1.26 \mathrm{E}-01$ & $1.25 \mathrm{E}-01$ & $5.39 \mathrm{E}-03$ & $6.32 \mathrm{E}-01$ & $6.27 \mathrm{E}-01$ \\
\hline${ }^{242} \mathrm{mAm}$ & NR & NR & NR & NR & NR & NR \\
\hline${ }^{242} \mathrm{Pu}$ & $9.36 \mathrm{E}-06$ & $2.14 \mathrm{E}-03$ & $2.14 \mathrm{E}-03$ & $1.70 \mathrm{E}-05$ & $1.07 \mathrm{E}-02$ & $1.07 \mathrm{E}-02$ \\
\hline${ }^{243} \mathrm{Am}$ & $3.90 \mathrm{E}-05$ & $1.04 \mathrm{E}-02$ & $1.04 \mathrm{E}-02$ & $7.10 \mathrm{E}-05$ & $5.22 \mathrm{E}-02$ & $5.22 \mathrm{E}-02$ \\
\hline${ }^{243} \mathrm{Cm}$ & $2.85 \mathrm{E}-04$ & $1.54 \mathrm{E}-02$ & $1.54 \mathrm{E}-02$ & $5.18 \mathrm{E}-04$ & $7.72 \mathrm{E}-02$ & $7.68 \mathrm{E}-02$ \\
\hline${ }^{244} \mathrm{Cm}$ & $2.21 \mathrm{E}-03$ & $6.31 \mathrm{E}-01$ & $6.30 \mathrm{E}-01$ & $4.02 \mathrm{E}-03$ & $3.15 \mathrm{E}+00$ & $3.15 \mathrm{E}+00$ \\
\hline Total & $1.14 \mathrm{E}+04$ & $3.33 \mathrm{E}+04$ & $2.96 \mathrm{E}+04$ & $2.08 \mathrm{E}+04$ & $1.67 \mathrm{E}+05$ & $1.48 \mathrm{E}+05$ \\
\hline
\end{tabular}


Table 13. 1988 Supernate Composition and Inventories of Chemicals

(formally known as) and Radionuclides That Potentially Leaked from Tank 241-AX-102

\begin{tabular}{|c|c|c|}
\hline Analyte & $\begin{array}{l}1988 \text { Supernate } \\
\text { Composition }^{2}(\mathrm{M})\end{array}$ & $\begin{array}{l}\text { Estimated Leakage from } \\
\text { Tank } 241-\mathrm{AX}-102^{\mathrm{b}}, \mathrm{kg}(\mathrm{Ci})\end{array}$ \\
\hline $\mathrm{Al}$ & 0.006 & 1.8 \\
\hline $\mathrm{Bi}$ & 0. & 0 \\
\hline $\mathrm{Ca}$ & 0.014 & 6.4 \\
\hline $\mathrm{CO}_{3}$ & 0.98 & 689.9 \\
\hline $\mathrm{Cr}$ & 0.004 & 2.4 \\
\hline $\mathrm{Fe}$ & 0.033 & 20.9 \\
\hline $\mathrm{K}-1$ & an $\quad 0.002 \ldots \quad \ldots$ & 0.88 \\
\hline $\mathrm{Mg}-\cdots \cdots$ & 0,0005 & $0: 14$ \\
\hline $\mathrm{Min}$ & 0.011 & 6.9 \\
\hline $\mathrm{Na}$ & 7.32 & 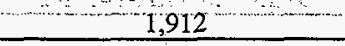 \\
\hline 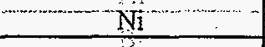 & 0.009 & 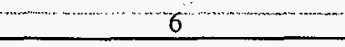 \\
\hline $\mathrm{NO}_{2}$ & 1.4 & $731-1-1-1$ \\
\hline $\mathrm{NO}_{3}$ & 3.7 & 2,605 \\
\hline Oxalate & $36.8 \mathrm{~g} / \mathrm{L}$ & $418 \quad-\cdots$ \\
\hline $\mathrm{PO}_{4}$ & $<0.056$ & 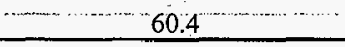 \\
\hline$\ldots+\cdots$ & 0.0009 & 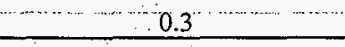 \\
\hline${ }^{24} \mathrm{Am}$ & $980^{\circ}(\mu \mathrm{Ci} / \mathrm{L})$ & $11 \mathrm{I}^{\circ} \mathrm{Ci}$ \\
\hline$-2399240 \mathrm{Pu}$ & $97^{\circ}(\mu \mathrm{Ci} / \mathrm{L})$ & $1 . \mathrm{I}^{\mathrm{C}} \mathrm{Ci}$ \\
\hline$-137 \mathrm{CS}$ & $265,265^{\mathrm{c}}(\mu \mathrm{Ci} / \mathrm{L})$ & $3,0 \mathrm{~T} 2^{\circ} \mathrm{Cl}$ \\
\hline${ }^{60} \mathrm{Co}$ & $146^{\circ}(\mu \mathrm{Ci} / \mathrm{L})$ & $81^{\circ}-C^{-}$ \\
\hline${ }^{90} \mathrm{Sr}$ & $127,755^{c}(\mu \mathrm{Ci} / \mathrm{L})$ & $1,450^{\circ} \mathrm{Ci}$ \\
\hline
\end{tabular}

Weiss, R I., 1988, Analysis of Tank 241-AX-102 Sample, Memorandum to J. A. Eaker, WHC-SD-WM-ER-309.

based on $11.3 \mathrm{~kL}(3 \mathrm{kgal})$ of potential leakage.

radionuclides decayed to December 31,1999. 


\section{APPENDIX D \\ BEST-BASIS INVENTORY, RETRIEVAL INVENTORY, AND LEAKAGE INVENTORY ESTIMATES FOR RETRIEVAL OF WASTE FROM SINGLE-SHELL TANK 241-AX-103}

D. W. Hendrickson, P.E.

S. L. Lambert, Ph.D.

SGN Eurisys Services Corporation

Richland, Washington 
2.0 CHEMICAL/RADIONUCLIDE INVENTORY ESTIMATES BEFORE

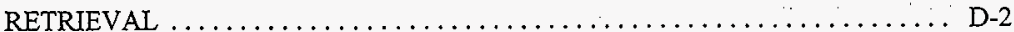

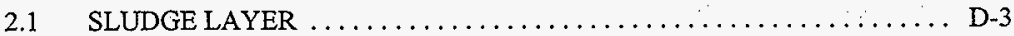

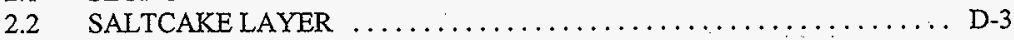

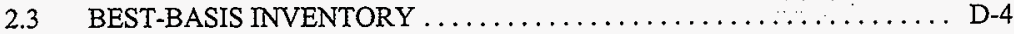

3.0 CHEMICAL/RADIONUCLIDE INVENTORY ESTIMATES AFTER

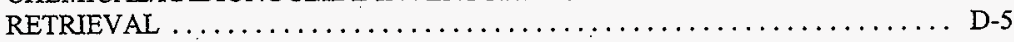

4.0 BEST-BASIS LEAKAGE INVENTORY ESTIMATES FOR RETRIEVAL OF

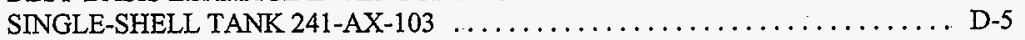

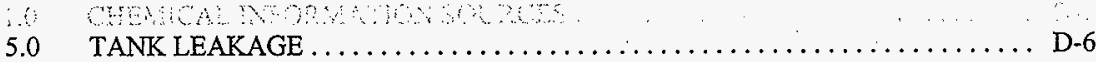

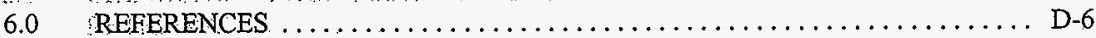

\section{TABLES:}

1. Analytical Results and Sludge Inventory Estimates for Nonradioactive Components

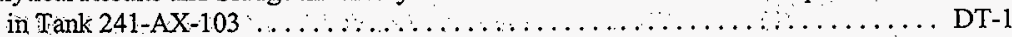

2. Analytical Results and Sludge Inventory Estimates for Radioactive Components

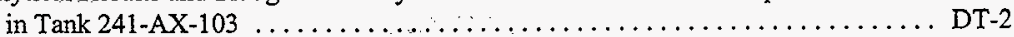

3. Projected Inventory of SRR Components in Tank 241-A-102 and Percent of Total Inventory Due to SRR Sludge $\ldots \ldots \ldots \ldots \ldots \ldots \ldots \ldots \ldots \ldots \ldots \ldots \ldots \ldots \ldots$

4. SMMA1 Saltcake Composition and Inventory Projections for Tank 241-AX-103. Based on Core Samples from Tanks 241-A-102 and 241-A-103 and Auger Samples from Tank $241-A-102 \ldots \ldots \ldots \ldots \ldots \ldots \ldots \ldots \ldots \ldots \ldots \ldots \ldots$ DT $4 a$

5. Analytical Results and Tank Inventory Estimates for Radioactive Components in SMMAl Saltcake in Tank 241-AX-103 Based on Core Samples from

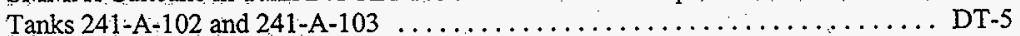

6. Best:Basis Nonradiological Inventory Before Retrieval of Waste from Single-Shell

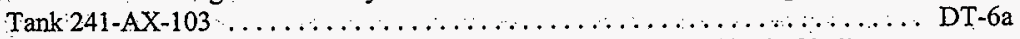

7. Best-Basis Radiological Inventory Before Retrieval of Waste From Single-Shell

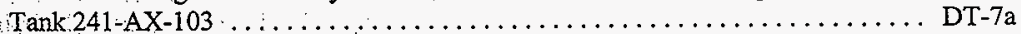

8. Retrieval Scenario Summary of Residual Waste and Fractional Removal .......... DT-8

9: Tank 24,1-AX-103 Nonradiological Waste Residual Inventory Following Retrieval .. DT-9a

10. Tank 241-AX-103 Radiological:Waste Residual Inventory Following Retrieval ... DT-10a

1.1. Retrieval Scenario Product Solution Nonradiological Analyte Concentrations ..... DT-1 la

12. Retrieval Scenario Product Solution Radiological Analyte Concentrations : $\ldots \ldots \ldots$ DT-12a

13. Tank 241-AX-103 Retrieval Scenario Nonradiological Constituent Leakage

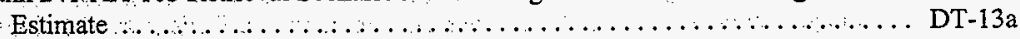

14. Tank 24:1-AX-103 Retrieval Scenario Radiological Constituent Leakage Estimate . DT-14a 
The purpose of this study is to provide the best-basis estimate of the chemical and radiological waste inventory after retrieval of waste from the 241-AX Tank Farm. As part of this effort, an evaluation of available information for Tank 241-AX-103 was performed and a best-basis inventory was established for two different retrieval scenarios. The first scenario is based on 99 percent retrieval of waste from the tank to meet the Hanford Federal Facility Agreement and Consent Order (Tri-Party Agreement) (Ecology et al. 1990) milestone of $101.9 \mathrm{~m}^{3}\left(360 \mathrm{ft}^{3}\right)$ of residual waste. The alternate scenario assumes a retrieval of 90 percent of the waste to a volume of $101.94 \mathrm{~m}^{3}\left(3,600 \mathrm{ft}^{3}\right)$ of residual waste, or left at the current volume if this volume is less than $101.94 \mathrm{~m}^{3}\left(3,600 \mathrm{ft}^{3}\right)$. This study, detailed in the following sections, is based on the methodology that was established by the standard inventory task.

\subsection{CHEMICAL INFORMATION SOURCES}

Chemical and radionuclide inventory estimates are generally derived from one of three sources of informationi (1) sämple analysis and sample derived inventory estimates, (2) component inventories predicted by the $H D W$ model based on process knowledge and historical tank transfer information, or (3) a tank-specific process estimate based on process flowsheets, reactor fuel (data; essential materials records; or comparable sludge layers and sample information from othet tanks methobos in:

Tank 241-AX-103 was sampled in September 1974 to determine the sludge composition prior to the 1976 sluicing campaign and again in September 1980 to establish the tank supernate composition before deactivation of the tank in 1981. Samples obtained prior to 1976 are of only limited value as most of the material was removed from this tank during the 1976 sluicing campaign. Similarly, supernate samples from the post 1976 period are of little interest because the supernate was transferred to Tank 241-A-102 during the fourth quarter of 1980 , or removed via saltwell:pumping to Tank 241-AN-101:in 1987.

artarters:

The wastehistory of this tank is provided in Anderson (1990) and Agnew et al. (1997a). Tank 241-AX-103 was initially used as a PUREX waste receiver from the first quarter of 1965 until the second quarter of 1966, with large transfers of PUREX (P2) waste and intermittent transfers of PUREX organic wash (OWW2) waste. Other transfers of PUREX organic wash (OWW2 and OWW3) waste occurred in 1966 and 1967, followed by transfers of B Plant (B) waste, PUREX low:level (PL1) waste, and supernate receipts from other tanks (241-A-104, 241-A-106, $241-\mathrm{AX}-101,241-\mathrm{AX}-102,241-\mathrm{AX}-104$ and $241-\mathrm{C}-106)$. AR vault (AR) sludge was added in 1975; while the tank was sluiced from March 1976 until the beginning of 1977, removing about $31.0 \mathrm{~kL}$ (82 kgal) of sludge (Rodenhizer 1987). The tank was isolated and stabilized in early 1977 and deactivated in 1981 , with the last salt well transfer occurring in 1987.

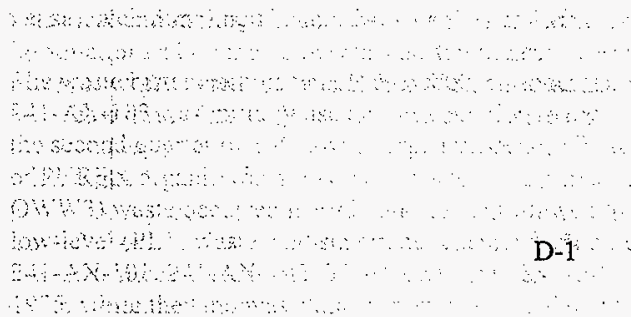




\subsection{CHEMICAL/RADIONUCLIDE INVENTORY ESTIMATES BEFORE RETRIEVAL}

After the 197.6 sluicing campaign; the residual sludge level was found to be $15.2 \mathrm{~cm}(6 \mathrm{in}$.) at riser 9B. This level was measured again in November 197.9 after dilute evaporator wastes were added to the tank and found to be $7.6 \mathrm{~cm}(3 \mathrm{in}$.$) and 25.4 \mathrm{~cm}(10 \mathrm{in}$.) at risers $9 \mathrm{D}$ and $9 \mathrm{E}$ (Bendixsen 1980). Based on these values, approximately $15.2 \mathrm{~cm}$ (6 in.) of residual sludge must have been.left in the tank after the 1976 sluicing campaign. This level is equivalent to a residual sludge inventory of $62.6 \mathrm{~kL}(16.5 \mathrm{kgal})$ in the $22.86 \mathrm{~m}$ (75 ft) diameter, flat bottom tank. This estimate is somewhat larger than the residual inventories reported by Anderson $(0$ to $6 \mathrm{kgal}$ of sludge. in 1980) and later by Agnew (14 kgal of sludge), based on the historical records for this tank (Anderson 1991, Agnew 1997b).

Approximately $1,635 \mathrm{~kL}$ (432 kgal) of 242-A evaporator concentrates were added to this tank in

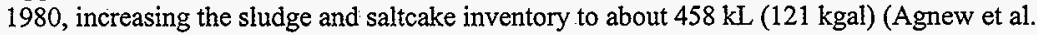
1997a). Because of salt well pumping, this inventory was later reduced to about $424 \mathrm{~kL}$ (112 kgal), which is consistent with the tank farm surveillance estimate $103.4 \mathrm{~cm}$ ( $40.7 \mathrm{in}$.) of solids, inclüding $7.6 \mathrm{~kL}$ (2: kgal) of sludge and $416.4 \mathrm{~kL}$ (110 kgal) of saltcake (Hanlon 1993): The Hanlon estimate is also consistent with current waste level measurements for this tank, 102.9- $\mathrm{cm}$ (40.5-in.) of waste as of January 1993, including a one-inch offset for the FIC plummet (Swaney:1993). Based on the 1979 sludge level measurements, it appears that the Hanlon sludge and saltcake estimates should be modified to match the 1979 sludge level data for this tank; $62.6 \mathrm{~kL}(16.5 \mathrm{kgal})$ of sludge and $361.4 \mathrm{~kL}(95.5 \mathrm{kgal})$ of saltcake. The best-basis standard inventory is based on the tank farm surveillance waste volume $(424 \mathrm{~kL})$, with revised inventory estimates of $62.6 \mathrm{~kL}$ (16.5 kgal) of sludge and $361.4 \mathrm{~kL}$ (95.5 kgal) of saltcake. This inventory is equivalent to 2,208 cubic feet of PUREX P2 sludge and 12,476 cubic feet of SMMA1 saltcake from the 242-A evaporator.

The residual sludge in Tank $241-\mathrm{AX}-103$ is considered to be similar in composition to the residual sludge in Tank 241 AX-104, Both tanks received PUREX high-level (P2) waste starting in 1965, while Tank 241-AX-103 received small transfers of PUREX organic wash:(OWW2) waste during this period. Both tanks were also sluiced in 1976 and 1977, leaving only a small heel of residual sludge (16.5 and $7 \mathrm{kgal}$, respectively, in Tanks 241 -AX-103 and 241-AX-104). A small sample of residual sludge was obtained from Tank 241-AX-104 after the 1976 sluicing campaign. The characteristics of this sludge were found to be consistent with the expected composition profile at PUREX P2 waste (best-basis inventory discussion for Tank 241-AX-104). Based on this analogy, it appears that this sample could also be used to estimate the residual waste composition profile for Tank 241-AX-103, with appropriate adjustments to OWW2 waste.

According to the HDW model, 3.9 volume percent of the $\mathrm{P} 2$ waste and 1.1 volume percent of the OWW2 waste are expected to precipitate as sludge in the primary receiver tank (Agnew 1997a). Based on the volume of such transfers in 1965 and 1966 , it appears that PUREX P2 waste could make up as much as 92 percent of the sludge and OWW2 waste eight percent of the sludge in Tank 241-AX-103 (92.5 $\mathrm{kgal}$ of $\mathrm{P} 2$ sludge and $9.0 \mathrm{kgal}$ of OWW2 sludge theoretically deposited in 1965 and 1966): 
About 3,092 kL ( $817 \mathrm{kgal}$ ) of OWW2 waste were transferred to this tank in 1965 and 1966 (Agnew 1997b). OWW2 waste contained about $0.004 \mathrm{~g}$ moles $/ \mathrm{L}$ of $\mathrm{MnO}_{2}$ and $3.5 \mathrm{E}-05 \mathrm{~kg} / \mathrm{L}$ of uranium (Anderson 1990). Based on these values, about $680 \mathrm{~kg}$ of $\mathrm{Mn}$ and $111 \mathrm{~kg}$ of uranium must have been added with OWW2 waste in 1965 and 1966. As all but $62.6 \mathrm{~kL}$ (16.5 kgal) of sludge were removed during the 1976 sluicing campaign, only about 16 percent of the OWW2 waste should be in the tank (16.5 kgal/92.5 kgal $+9 \mathrm{kgal})$. Thus, $109 \mathrm{~kg}$ of $\mathrm{Mn}$ and $18 \mathrm{~kg}$ of uranium may have been added to the residual sludge layer from OWW2 waste.

\subsection{SLUDGE LAYER}

Since the residual sludge layers in Tanks 241-AX-103 and 241-AX-104 were derived from a common source, the 1977 grab sample from Tank $241-\mathrm{AX}-104$ will be used in this analysis to estimate the waste composition profile for Tank 241-AX-103. The 1977 grab sample concentrations from Tank 241-AX-104 for.both the washed sludge and the wash solution are listed in Tables 1 and 2 for nonradioactive and radioactive components, respectively. The grab sample concentrations for:Tank 241-AX-104 are reported on a "per liter of sludge" basis The Tank 2412 AX 103 sludge layer inventory for Tank $241-\mathrm{AX}-102$; summarized in Tables 1 and 2, is calculated by multiplying the sum of the washed sludge and wash solution concentrations in Tank $241=\mathrm{AX}-104$ sludge by the volume of the sludge in Tank $241 \mathrm{HAX}-103:(62.6 \mathrm{~kL}$ [16.5 kgal]), with the indicated corrections for manganese and uranium from OWW2 waste (109 kg of manganese and $18 \mathrm{~kg}$ of uranium from OWW2 sludge).

\subsection{SALTCAKE LAYER}

During the second and third quarters of 1980 , approximately $1,635 \mathrm{~kL}$ (432 kgal) of evaporator concentrates were added to Tank 241-AX-103 from the 242-A evaporator-crystallizer. After this transfer, the waste inventory increased to $458 \mathrm{~kL}(121 \mathrm{kgal})$, and later because of salt well pumping, gradually decreased to the present inventory of $424 \mathrm{~kL}$ ( $112 \mathrm{kgal})$. (Agnew $1997 \mathrm{a}$, : Hanlon 1993, Swaney 1993). Some $361.4 \mathrm{~kL}$ (95.5 kgal) of this inventory is due to the 3. accumulation of saltcake from the $242 \mathrm{~A}$ evaporator. This saltcake is referred to as SMMAlis saltcake in the HDW model. While saltcakeicompositions probably varied from batch to batch (depending on the source of concentrated supernate), large volumes of saltcake were also added to Tanks 24:1-A-102 and 241-A-103 during this same time period. These tanks are of interest because both tanks were sluiced in 1976 to a residual inventory of only 4 to $11 \mathrm{~kL}$ ( 1 to $3 \mathrm{kgal}$ ) of sludge and both were sampled after receiving large volumes of 242-A evaporator saltcake in $1977-1980$.

Tank:241-A-102 was sluiced in 1964, 1972-1974, and once again in 1976 to a residual heel of about 1 1 kC: (3 kgal) of strontium recovery (SRR) sludge (Anderson 1990, Agnew 1997a). Based on the HDW:model; this tank currently contains $11 \mathrm{~kL}(3 \mathrm{kgal})$ of SRR sludge and $1287 \mathrm{~kL}$ ( $34 \mathrm{kgal}$ ) of SMMA 1 saltcake, values which are generally consistent with the current inventory estimates for this tank (147.6 kJ or $39 \mathrm{kgal}$ according to Swaney 1993 and $155 \mathrm{~kL}$ or 41: kgaliniHanlon 1993). Thus, 92 percent of this waste apparently consists of 242-A evaporator saltcake Two fullidepth core samples were obtained from riser 4 in 1986 and two auger : samples; the first from riser 19 in June 1995 and the second from riser 5 in March 1996, were also obtained for safety screening analysis. Core segment recoveries were determined to be 
(formal1y known as)

nearly 100 percent for each core. Composite samples from the two 1986 cores and 1996 auger sample were analyzed to determine the chemical and radionuclide composition of the waste. The analytical results are summarized in the TCR (Morris 1996).

Table 3 shows the projected inventory of key components in the residual SRR sludge layer in Tank 241-A-102, based on the HDW model. This model assumes that $11.3 \mathrm{~kL}$ ( $3 \mathrm{kgal})$ of SRR sludge were left in this tank, and that this sludge has an average density of $1.322 \mathrm{~kg} / \mathrm{L}$.

Tank 241-A-103 was also sluiced in the 1960s, in 1974, and once again in 1976, to a residual sludge heel of $11.3 \mathrm{~kL}$ (3 kgal) of AR vault (AR) sludge (Anderson 1990, Agnew 1997b). According to the HDW model, this tank currently contains $11 \mathrm{~kL}$ ( $3 \mathrm{kgal})$ of AR sludge and $1,374 \mathrm{~kL}$ ( $363 \mathrm{kgal}$ ) of SMMA1 saltcake from the $242-\mathrm{A}$ evaporator, values which are generally consistent with current inventory projections for this tank $(1,430 \mathrm{~kL}$ or $378 \mathrm{kgal}$ based on Swaney 1993 and $1 ; 400 \mathrm{~kL}$ or $370 \mathrm{kgal}$ in Hanlon 1993). Consequently; about $99: 2$ percent of this waste apparently consists of 242-A evaporator saltcake. Two full-depth core samples wete taken fromarisers 12 and 17. of this tank in March 1986.: Excellent recoveries were obtained for each core. Composite samples from each core were analyzed to determine chemical and radioniclide composition of the waste, with the results summarized in the data transmittal package for this tank (Weiss and Schull 1988).

Table 4 summarizes the SMMA1 saltcake compositions derived from Tanks 241-A-102 and 24.1:A-103 - Saltcake inventory estimates for Tank $241-\mathrm{AX}-103$ are based on $361.4 \mathrm{~kL}$ $(95: 5 \mathrm{kgal})$ of salteake, with an average density of $1.4975 \mathrm{~kg} / \mathrm{L}$ from sample data. This estimate is reasonably consistent with the average density of 1.5133 derived from the HDW model for SMMA: saltcake:in Tanks 241-A-102, 241-A-103, and 241-AX-103.

Table 5 summarizes the mean radionuclide concentrations and tank inventory estimates for SMMA1 saltcake based on core and auger samples from Tanks 241-A-102 and 241-A-103. Radionuelide results in Table 5 have been decayed to January 1, 1994. Further decay is provided in the best-basis inventory tables. The original analytical values for Tank $241-\mathrm{A}-102$ may be found in the tank characterization report (Morris 1996), and for Tank 241-A:103, in the data tranșittalpackage for this tank (Weiss and Schull 1988a).

\subsection{BEST-BASIS INVENTORY}

Based on this analysis; a best-basis inventory was developed. The full-depth core samples and aliger samples (of SMMA1 saltcake) from Tanks 241-A-1.02 and 241-A-103, together with the 1977 sample (of PUREX P2 waste) from Tank 241-AX-104 were used to generate estimates for the chemical and radionuclide components in this waste. This waste consists primarily of SMMA1 saltcake from the 242-A evaporator and a small volume of PUREX high-level (P2). sludge andPUREX organic wash (OWW2) sludge waste from Al-clad fuel. Once the best-basis inventories were determined, the hydroxide inventory was calculated by performing a charge balance with the valences of other analytes. In some cases, this approach requires that other analyte (e.g.; sodium or nitrate) inventories be adjusted to achieve the charge balance. During such adjustments, the number of significant figures is not increased. This charge balance approach is consistent with that used by Agnew et al. (1997a). 
Best-basis radionuclide values were derived for $46 \mathrm{key}$ radionuclides (Kupfer et al. 1997). Waste sample analyses have often only reported ${ }^{90} \mathrm{Sr},{ }^{137} \mathrm{Cs},{ }^{239 / 240} \mathrm{Pu}$, and total uranium (or total beta and total alpha), while other key radionuclides, such as ${ }^{60} \mathrm{Co},{ }^{99} \mathrm{Tc},{ }^{129} \mathrm{I},{ }^{154} \mathrm{Eu},{ }^{155} \mathrm{Eu}$, and ${ }^{241} \mathrm{Am}$, etc., have been infrequently reported. For this reason it was necessary to derive most of the 46 key radionuclides by computer models. These models estimate radionuclide activity in batches of reactor fuel, account for the split of radionuclides to various separations plant waste streams, and track their movement with tank waste transactions. (Kupfer et al. 1997 and Watrous and Wootan 1997.) Model-generated values for radionuclides in any of the 177 tanks are reported in the HDW Rev. 4 model results (Agnew et al. 1997a). (No attempt has been made to ratio or normalize model results for all 46 radionuclides when values for measured radionuclides disagree with the model.) For a discussion of typical error between model-derived values and sample-derived values (Kupfer et al. 1997).

The best-basis inventory for Tank 241-AX-103 is presented in Tables 6 and 7. A medium level of confidence is assigned to the chemicals and radionuclides in these tables because of the good comparisons found between the sample-based and $\mathrm{HDW}$ model-based estimates for many of the saltcake components, including $\mathrm{Al}, \mathrm{Cl}, \mathrm{CO}_{3}, \mathrm{Cr}, \mathrm{NO}_{3}, \mathrm{NO}_{2}$, and $\mathrm{Na}$.

\subsection{CHEMICAL/RADIONUCLIDE INVENTORY ESTIMATES AFTER RETRIEVAL}

As part of this study, a best basis inventory was established for three different retrieval scenarios. The first scenario is based on retrieving waste to minimum of either the existing waste volume or a residual waste volume of $101.94 \mathrm{~m}^{3}\left(3600 \mathrm{ft}^{3}\right)$. The second scenario assumes retrieval to a residual waste volume of $10.2 \mathrm{~m}^{3}\left(360 \mathrm{ft}^{3}\right)$ which corresponds to the assumed 99 percent retrieval of waste to meet the Tri-Party Agreement (Ecology et al. 1990). The third scenario assumes retrieval to a residual waste volume of $1.02 \mathrm{~m}^{3}\left(36 \mathrm{ft}^{3}\right)$. The first and third scenarios represent the retrieval of all tank wastes to 90 percent and 99.9 percent respectively.

Table 8 contains a summary matrix of resultant saltcake and sludge volumes, and their fractional removal, following retrieval according to the three scenarios of 90 percent, 99 percent, and 99.9 percent retrieval:

Following retrieval according to the three scenarios presented in Table 8, residual tank waste inventory has been evaluated and is presented in Tables 9 and 10 for chemical and radiological constituents, respectively.

\subsection{BEST-BASIS LEAKAGE INVENTORY ESTIMATES FOR RETRIEVAL OF SINGLE-SHELL TANK 241-AX-103}

The retrieval scenarios described in Section 3.0 provide residual inventories following fractional removal of any saltcake and sludges contained within Tank 241-AX-101. This section assumes two different leakage conditions for each retrieval scenario. The first leakage condition assumes 
(formally known as)

up to $30.2 \mathrm{~m}^{3}$ ( $8 \mathrm{kgal}$ ) of potential leakage, while the second leakage condition is based on an upper bounding estimate of $151.4 \mathrm{~m}^{3}$ (40 kgal) of potential leakage. In each case, solution concentrations and inventories will be based on the limiting conditions for waste retrieval, either a maximum supernate concentration of five gram moles per liter sodium or a maximum value of 10 weight percent solids in the slurry, or the total volume of the retrieval solution. These limits were established to minimize the possible crystallization of sodium rich salts in the slurry transfer lines and slurry pumping problems for the slury pumps and sluicers. The following estimates are based on the methodology that was established by the standard inventory task.

The solution concentrations resulting from dissolution and slumy with water of the tank waste to the three retrieval scenarios are provided in Tables 11 and 12 for nonradiological and radiological constituents. Table 11 also displays the limiting volume assessment required for application of sodium loading or solids loading limits and the minimum retrieval water to meet the limiting:volume assessment based upon product-specific gravities of either 1.17 or 1.18 for sodium limited or solids limited solutions.

Tables 13 and 14 contain the nonradiological and radiological, resultant leakage inyentory estimates based upon $30.2 \mathrm{~m}^{3}\left(1,066.5 \mathrm{ft}^{3}\right)$ and $151.4 \mathrm{~m}^{3}\left(5,346.7 \mathrm{ft}^{3}\right)$ releases during retrieval.

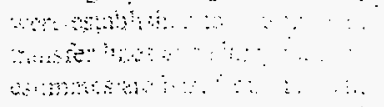

\subsection{TANK LEAKAGE}

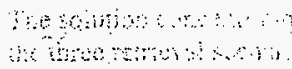

Tank $241-A X-103$ is currently considered to be a sound tank with no compelling evidence of leakage A total of six dry wells have been drilled around the periphery of Tank 241-AX-103. Dry, wells 11-03-02,11-03-07; and 11-03-09 have produced radiation counts more than 50 counts per second above background. If, during the course of spectral gamma logging, it is determined that some leakage did occur from this tank, the chemical and radionuclide source terms could be estimated from the available supernate composition data for this tank. Supernate samples were taken from this tank in October 1974 and April 1980, which should bracket any potential leakage event: This data will not be included in this submittal because there is presently no evidence that this tank has ever leaked.

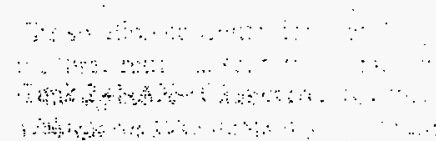

\subsection{REFERENCES}

Agnew, S. F., J. Boyer, R. Corbin, T. Duran, J, FitzPatrick, K. Jurgensen, T. Ortiz, and B. ra. Young, 1997a, Hanford Tank Chemical and Radionuclide Inventories: HDW Model Rev. $\therefore$ 4, LA-UR-96-3860, Los Alamos National Laboratory, Los Alamos, New Mexico. $\sin 1+\cdots, \cdots$

Agnew, S. F., R. A. Corbin, T. B. Duran, K. A. Jurgensen, T. P. Ortiz, and B. L. Young, 1997b, $\therefore$ Waste Status and Transaction Records Summary (WSTRS Rev. 4), LA-UR-97-311, Rev. $\therefore 0$ Eos Alamos National Laboratory, Los Alamos, New Mexico. 
Allen, G. K., 1976, Estimated Inventory of Chemicals Added to Underground Waste Tanks, 1944 through 1975, ARH-CD-610 B, Atlantic Richfield Hanford Company, Richland, Washington.

Anderson, J. D., 1990, A History of the 200 Area Farms, WHC-MR-0132, Westinghouse Hanford Company, Richland, Washington.

Bendixsen, R. B., 1980, Dilute Waste Concentration 242-A Evaporator-Crystallizer Campaign 80-2, October 28-November 11, 1979, RHO-CD-80-1045 2, Rockwell Hanford Company, Richland, Washington.

Ecology, EPA, and DOE, 1990, Hanford Federal Facility Agreement and Consent Order, 2 vols., as amended, Washington State Department of Ecology, U.S. Environmental Protection Agency, U.S. Department of Energy, Olympia, Washington.

Hanlon, B M.; 1997, Waste Tank Summary Report for Month Ending March 31, 1997, HNF-EP-0182-108, Lockheed Martin Hanford Corporation, Richland, Washington.

Kupfer, M I., A, L. Boldt, B A. Higley, K. M.Hodgson, L. W. Shelton, and R. A. Watrous (LMHC), S. L. Lambert, and D. E. Place (SESC), R. M. Orme (NHC), G. L. Borsheim (Borsheim Associates); N. G. Colton.(PNNL), M. D. LeClair.(SAIC), and R. T. Winward (Meier Associates), and W. W: Schulz (W' ${ }^{2} \mathrm{~S}$ Corporation), 1997, Standard Inventories of Chemicals and Radioniuclides in Hanford Site Tank Wastes, HNF-SD-WM-TI-740, Rev. 0 , (to be issued), Lockheed Martin Hanford Corporation, Richland, Washington.

Lambert, S. L., and D. W. Hendrickson; 1997, Preliminary Tank Characterization Report for Single-Shell Tank 24I-AX-104: Best-Basis Inventory, HNF-SD-WM-ER-675, Rev. 0, SGN Eurisys Services Corporation, Richland, Washington:

Larson, D. E., 1967,B-Plant Phase III Flowsheets, ISO-986, Isochem, Inc., Richland, Washington.

Morris, B.J., 1996, Tank Characterization Report for Single-Shell Tank 241-A-102, WHC-SD-WM-ER-597, Westinghouse Hanford Company, Richland, Washington.

Rodenhizer, D. G., 1987, Hanford Waste Tank Sluicing History, SD-WM-TI-302, Westinghouse Hanford Company, Richland, Washington.

Starr, J.L, 1977, 104-AX Sludge Analysis, WHC-SD-WM-ER-309, Rev.0, Rockwell Hanford Operations; Richland, Washington:

Swaney, S. L., 1993, Waste Level Discrepancies Between Manual Level Readings and Current Waste: Inventory for Single-Shell Tanks, Memorandum to. G. T. Frater 7C242-93-038, Westinghouse Hanford Company, Richland, Washington.

Van Tuyl, H.: H:, 1958, Composition of Some PUREX Plant 1 WW Solutions, HW-57280, General Elẹctric Co., Richland, Washington. 
Watrous, R. A., and D. W. Wootan, 1997, Activity of Fuel Batches Processed Through Hanford Separations Plants, 1944 Through 1989, HNF-SD-WM-TI-794, Rev. 0, Lockheed Martin Hanford Corporation, Richland, Washington.

Weiss, R. L., and K. E. Schull, 1988a, Data Transmittal Package for 241-A-103 Waste Tank Characterization, WHC-SD-RE-TI-198, Westinghouse Hanford Company, Richland, Washington.

Weiss, R. L., and K. E. Schull, 1988b, Data Transmittal Package for Tank 241-A-102 Waste Tank Characterization, WHC-SD-RE-TI-201, Westinghouse Hanford Company, Richland, Washington. 
Table 1. Analytical Results and Sludge Inventory Estimates for Nonradioactive Components in Tank 241-AX-103

\begin{tabular}{|c|c|c|c|}
\hline Component & $\begin{array}{c}1977 \text { Sludge } \\
\text { Concentration }(\mathrm{M})^{\mathrm{a}}\end{array}$ & $\begin{array}{l}1977 \text { Wash Solution } \\
\text { Concentration }(M)^{\mathbf{b}}\end{array}$ & $\begin{array}{c}\text { Sludge Layer } \\
\text { Inventory in Tank } \\
241-\mathrm{AX}-103(\mathrm{~kg})^{\mathrm{c}}\end{array}$ \\
\hline Density & 1.80 & $\mathrm{~g} / \mathrm{mL}$ & \\
\hline $\mathrm{Al}$ & 2.465 & 0.013 & 4,182 \\
\hline $\mathrm{Ba}$ & 0.021 & NR & 180.4 \\
\hline $\mathrm{Ca}$ & 0.642 & NR & 1608 \\
\hline $\mathrm{Cd}$ & 0.015 & NR & 105.5 \\
\hline $\mathrm{Cr}$ & 0.061 & NR & 198.4 \\
\hline $\mathrm{Fe}$ & 5.31 & NR & 18,549 \\
\hline $\mathrm{Mg}$ & 0.171 & $\mathrm{NR}$ & 260 \\
\hline $\mathrm{Mn}$ & 0.0845 & $\mathrm{NR}$ & 399 \\
\hline $\mathrm{Na}$, manu: & 2.99 & 0.337 & 4,784 \\
\hline $\mathrm{Ni}$ & 0.26 & NR & $955 \therefore$ \\
\hline $\mathrm{NO}_{2}$ & $\mathrm{NR}$ & 0.083 & 239 \\
\hline $\mathrm{NO}_{3}$ & $<1.140$ & 0.09 & $<4770$ \\
\hline $\mathrm{OH}$ & $\mathrm{NR}$ & 15.6 & 16,595 \\
\hline $\mathrm{P}$ as $\mathrm{PO}_{4}$ & 0.11 & NR & 653 \\
\hline$P$ & 0.11 & $\mathrm{NR}$ & 213.1 \\
\hline Si:as $\mathrm{SiO}_{3}$ & 2.485 & $\mathrm{NR}$ & 11,826 \\
\hline $\mathrm{S}$ as $\mathrm{SO}_{4}$ & 0.125 & 0.01 & $811 \cdots$ \\
\hline$S^{\prime: \ldots}$ & 0.125 & 0.01 & 271 \\
\hline Total U & $1.79 \mathrm{E}-05$ & $\mathrm{NR}$ & 18.27 \\
\hline $\mathrm{H}_{2} \mathrm{O} \cdots$ & 40.97 & NR & 46,162 \\
\hline $\mathrm{Pu}(\mathrm{g} / \mathrm{L})_{\mathrm{u}}$ & 0.213 & NR & 13 \\
\hline \multicolumn{4}{|c|}{$\begin{array}{l}\text { Average of two KOH fusion determinations from September } 1977 \mathrm{grab} \\
\text { sample (Starr 1977). } \\
\mathrm{b} \\
\text { Wash solution composition based on mass of washed sludge }(1.8 \mathrm{~g} / \mathrm{mL}) \\
\text { Sludge inventory based on } 26.6 \mathrm{~kL} \text { of sludge with an average density of } 1.80 \\
\mathrm{~kg} / \mathrm{L}\end{array}$} \\
\hline
\end{tabular}

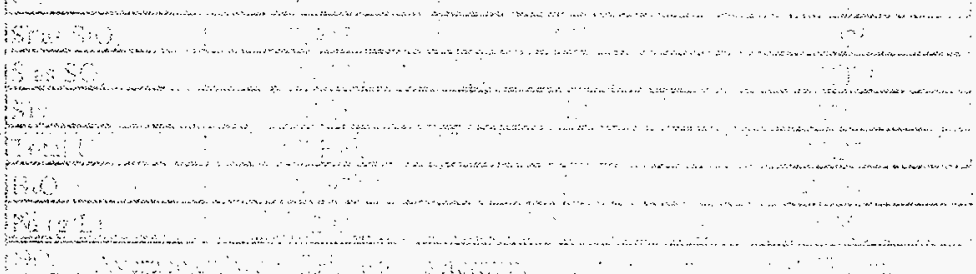


Table 2. Analytical Results and Sludge Inventory Estimates for Radioactive Components in Tank 241-AX-103

\begin{tabular}{|c|c|c|c|}
\hline Component & \begin{tabular}{|c|}
1977 Sludge \\
Concentration $(\mathrm{Ci} / \mathrm{L})$ \\
\end{tabular} & $\begin{array}{l}1977 \text { Wash Solution } \\
\text { Concentration }(\mathrm{Ci} / \mathrm{L})\end{array}$ & $\begin{array}{l}\text { Sludge Layer Inventory in } \\
\text { Tank 241-AX-103 (Ci) }\end{array}$ \\
\hline Decay & $12 / 31 / 99$ & $12 / 31 / 99$ & $12 / 31 / 99$ \\
\hline${ }^{60} \mathrm{Co}$ & 0.0059 & NR & 372 \\
\hline${ }^{90} \mathrm{Sr}$ & 51.5 & 0.0133 & $3.22 \mathrm{E}+06$ \\
\hline${ }^{90} \mathrm{Y}$ & 51.5 & 0.0133 & $3.22 \mathrm{E}+06$ \\
\hline${ }^{125} \mathrm{Sb}$ & 0.0024 & NR & 148 \\
\hline${ }^{137} \mathrm{Cs}$ & 1.063 & 0.0086 & 66,821 \\
\hline${ }^{137} \mathrm{mBa}$ & 1.006 & 0.0081 & 63,212 \\
\hline${ }^{154} \mathrm{Eu}$ & 0.0434 & $\mathrm{NR}$ & 2713 \\
\hline${ }^{155} \mathrm{Eu}$ & 0.0279 & NR & 1744 \\
\hline $2331240 \mathrm{Pu}$ & $0: 0132$ & $\mathrm{NR}$ & 824 \\
\hline \multicolumn{4}{|c|}{$\begin{array}{l}\text { Based on decayed mean of } 1977 \text { sludge sample (Start 1977) } \\
\text { Based on decayed mean of } 1977 \text { wash solution results (Starr 1977) } \\
\text { Sludge inventory based on } 62.5 \mathrm{~kL}(16.5 \mathrm{kgal}) \text { of sludge with a density of } \\
1.80 \mathrm{~kg} / \mathrm{L} \text {. }\end{array}$} \\
\hline
\end{tabular}

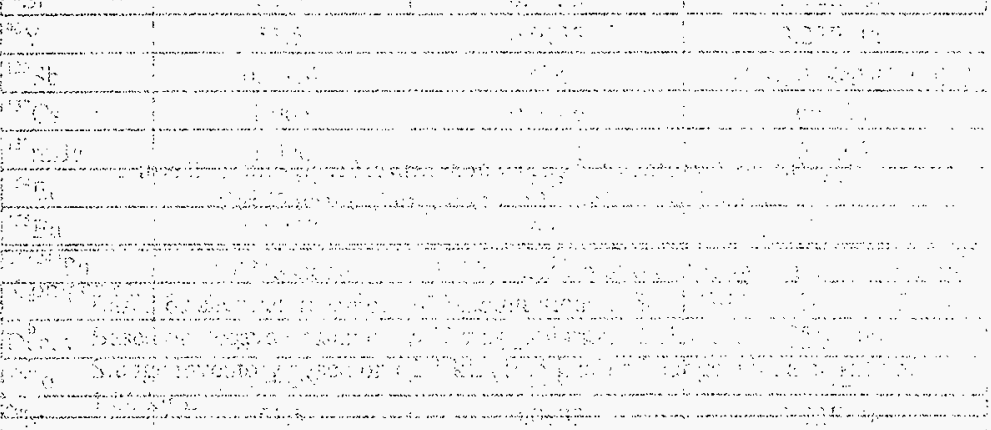


Table 3. Projected Inventory of SRR Components in Tank 241-A-102 and Percent of Total Inventory Due to SRR Sludge

\begin{tabular}{|c|c|c|c|c|}
\hline Analyte & $\begin{array}{l}\text { Average } \\
\text { Concentration } \\
\quad(u g / g)\end{array}$ & $\begin{array}{c}\text { Projected } \\
\text { Inventory in } \\
\text { SRR Sludge } \\
(\mathrm{kg})\end{array}$ & $\begin{array}{c}\text { Sample-Based Inventory } \\
\text { in Tank } 241-\mathrm{A}-102^{\circ} \\
(\mathrm{kg})\end{array}$ & $\begin{array}{l}\text { Percent Due } \\
\text { to SRR } \\
\text { Sludge }\end{array}$ \\
\hline $\mathrm{Ca}$ & 4,146 & 62 & 410 & $15.1 \%$ \\
\hline $\mathrm{CO}_{3}$ & 15,490 & 232 & 5,724 & $4.1 \%$ \\
\hline $\mathrm{Fe}$ & 53,951 & 809 & 4,358 & $18.6 \%$ \\
\hline $\mathrm{NO}_{3}$ & 19,406 & 291 & 21,949 & $1.3 \%$ \\
\hline$\overline{\mathrm{Si}}$ & 14,075 & 211 & 2,563 & $8.2 \%$ \\
\hline $\mathrm{Na}$ & 112,406 & 1,687 & 40,087 & $4.2 \%$ \\
\hline $\begin{array}{l}\mathrm{B} \\
\mathrm{B} \\
\mathrm{al}\end{array}$ & \multicolumn{4}{|c|}{$\begin{array}{l}\text { Based on the concentration of SRR sludge in the HDW model (Agnew et. al: 1997a), } \\
\text { Based on } 11.3 \mathrm{~kL}(3 \mathrm{kgal}) \text { of waste with an average density of } 1.322 \mathrm{~kg} / \mathrm{L} \text { (Agnew et } \\
\text { al 1997a). }\end{array}$} \\
\hline $\begin{array}{l}\mathrm{B} \\
\text { sa } \\
1:\end{array}$ & \multicolumn{4}{|c|}{$\begin{array}{l}\text { Based on average analyte concentrations from } 1986 \text { core samples and } 1996 \text { auger } \\
\text { sample, with a total waste inventory of } 139: 7 \mathrm{~kL} \text { (37 kgal) and average waste density of } \\
1.645 \mathrm{~kg} / \mathrm{L}\end{array}$} \\
\hline
\end{tabular}

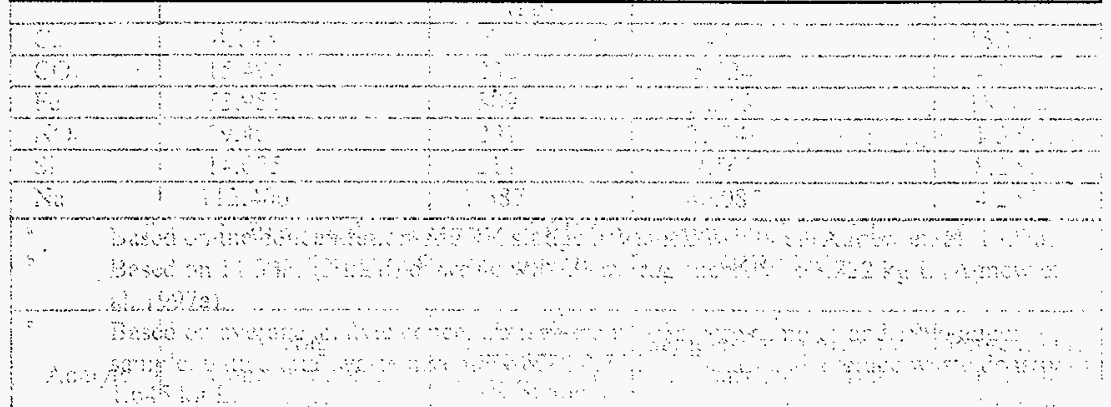


(formaliy known as)

Table 4. SMMA1 Saltcake Composition and Inventory Projections for

Tank 241-AX-103 Based on Core Samples from Tanks 241-A-102 and 241-A-103 and Auger Samples from Tank 241-A-102 (page 1 of 2)

\begin{tabular}{|c|c|c|c|c|c|}
\hline \multirow[b]{2}{*}{ Analyte } & \multicolumn{2}{|c|}{ 241-A-102 Sample Data" } & \multirow{2}{*}{$\begin{array}{c}\text { Tank 241-A-103 } \\
\text { Core Sample Data } \\
(\mu \mathrm{g} / \mathrm{g})^{6}\end{array}$} & \multirow{2}{*}{$\begin{array}{l}\text { Average Artalyte } \\
\text { Concentration in } \\
\text { SMMA1 Saltcake } \\
\mu \mathrm{g} / \mathrm{g}\end{array}$} & \multirow{2}{*}{$\begin{array}{c}\text { Estimated Inventory of } \\
\text { SMMA1 Saltcake in } \\
\text { Tank 241-AX-103 } \\
(\mathrm{kg})^{\circ}\end{array}$} \\
\hline & $\begin{array}{c}1986 \text { Core } \\
\text { Sample }(\mu \mathrm{g} / \mathrm{g})\end{array}$ & $\begin{array}{c}1996 \text { Auger } \\
\text { Sample } \\
(\mu \mathrm{g} / \mathrm{g})\end{array}$ & & & \\
\hline Density & 1.59 & 1.7 & 1.345 & 1.495 & 1.495 \\
\hline Ag & 247 & 371 & 24.7 & 167 & 90 \\
\hline $\mathrm{Al}$ & 23,265 & 31,700 & 16,570 & 22,026 & 11,904 \\
\hline As & $\therefore \mathrm{NR} \therefore$ & NR : : & $\mathrm{NR}$ & $\mathrm{NR}$ & $\therefore \mathrm{NR}$ \\
\hline $\mathrm{B}$ & 142 & $\mathrm{NR}$ & 22.2 & 18.2 & 9.9 \\
\hline $\mathrm{Ba}$ & 882 & 139 & 575 & 543 & 293 \\
\hline $\mathrm{Bi}$ & 1,738 & 336 & 176 & 607 & 328 \\
\hline $\mathrm{Ca}$ & 2,592 & 690 & 1,716 & 1,678 & 907 \\
\hline $\mathrm{Cd}$ & 65 & $\mathrm{NR}$ & $\therefore 80$ & 72 & 39 \\
\hline $\mathrm{Cl}$ & $\mathrm{NR}$ & NR & $\because \mathrm{NR}$ & $\because \mathrm{NR}$ & $\mathrm{NR}$ \\
\hline $\mathrm{TIC}$ as $\mathrm{CO}_{3}$ & $\mathrm{NR}$ & 21,700 & $\mathrm{NR}$ & 21,700 & 11,728 \\
\hline $\mathrm{Cr}$ & 5,270 & 8,800 & 1,531 & 4,283 & 2,315 \\
\hline $\mathrm{Cu}$ & 82 & NR & 12.3 & 47 & 25 \\
\hline $\mathrm{F}$ & $\mathrm{NR}$ & 277 & NR & 277 & 150 \\
\hline $\mathrm{Fe}$ & 13,936 & 19,600 & 355 & $8,5,61$ & 4,627 \\
\hline $\mathrm{Hg}$ & $\mathrm{NR}$ & NR & $\mathrm{NR}$ & NR & NR \\
\hline $\mathrm{K}$ & $2 ; 816$ & 3,080 & 2,534 & 2,741 & 1,481 \\
\hline $\mathrm{La}$ & $\mathrm{NR}$ & 103 & $\mathrm{NR}$ & 103. & 56 \\
\hline $\mathrm{Mg}$ & 1,382 & $\mathrm{NR}$ & 795 & 1,088 & -588 \\
\hline $\mathrm{Mn}$ & 2,151 & 3,380 & 124 & 1,445 & 781 \\
\hline $\mathrm{Na}$ & 187,045 & 129,000 & 208,605 & 183,314 & 99,071 \\
\hline $\mathrm{Ni}$ & 526 & 413 & 93 & 281 & 152 \\
\hline $\mathrm{NO}_{2}$ & $\mathrm{NR}$ & 83,200 & $\mathrm{NR}$ & 83,200 & 44,965 \\
\hline $\mathrm{NO}_{3}$ & 178,500 & 90,300 & 113,500 & 123,950 & 66,988 \\
\hline $\mathrm{OH}$ & $\mathrm{NR}$ & $N R$ & $\mathrm{NR}$ & $\mathrm{NR}$ & NR \\
\hline $\mathrm{Pb}$ & 1,186 & 1,410 & 364 & 831 & 449 \\
\hline${\mathrm{P} \text { as } \mathrm{PO}_{4}}$ & 16,061 & 4,906 & 6,655 & 8,569 & 4,631 \\
\hline $\mathrm{P}$ & 5,238 & NR & 2,170 & 3,704 & 2,002 \\
\hline $\mathrm{Se}$ & NR & NR & $\mathrm{NR}$ & NR & NR \\
\hline $\mathrm{Si} \mathrm{as} \mathrm{SiO}{ }_{3}$ & 44,778 & 10,619 & 29,929 & 28,814 & 15,572 \\
\hline $\mathrm{S}$ as $\mathrm{SO}_{4}$ & $\mathrm{NR}$ & $4,480^{\circ}$ & $\mathrm{NR}$ & 4,480 & 2,421 \\
\hline$S$ & $\mathrm{NR}$ & $\mathrm{NR}$ & $\mathrm{NR}$ & $\mathrm{NR}$. & $\mathrm{NR}$ \\
\hline & 98 & 31.5 & 12.0 & 38.3 & 20.7 \\
\hline
\end{tabular}


Table 4. SMMA1 Saltcake Composition and Inventory Projections for ${ }^{\text {known as) }}$

Tank 241-AX-103 Based on Core Samples from Tanks 241-A-102 and 241-A-103 and Auger Samples from Tank 241-A-102 (page 2 of 2)

\begin{tabular}{|c|c|c|c|c|c|}
\hline \multirow[b]{2}{*}{ Analyte } & \multicolumn{2}{|c|}{ 241-A-102 Sample Data ${ }^{a}$. } & \multirow{2}{*}{$\begin{array}{l}\text { Tank 241-A-103 } \\
\text { Core Sample Data } \\
\quad(\mu \mathrm{g} / \mathrm{g})^{\mathrm{b}}\end{array}$} & \multirow{2}{*}{$\begin{array}{c}\text { Average Analyte } \\
\text { Concentration in } \\
\text { SMMAI Saltcake } \\
\mu \mathrm{g} / \mathrm{g}\end{array}$} & \multirow{2}{*}{$\begin{array}{c}\text { Estimated Inventory of } \\
\text { SMMA1 Saltcake in } \\
\text { Tank 24I-AX-103 } \\
(\mathrm{kg})^{\mathrm{c}}\end{array}$} \\
\hline & $\begin{array}{c}1986 \text { Core } \\
\text { Sample }(\mu \mathrm{g} / \mathrm{g}) \\
\end{array}$ & $\begin{array}{l}1996 \text { Auger } \\
\text { Sample } \\
(\mu \mathrm{g} / \mathrm{g})\end{array}$ & & & \\
\hline TOC & 7,570 & & & 9,548 & 5,160 \\
\hline Total U & 1 & & 1, & 9,8 & -5 \\
\hline $\mathrm{Zn}$ & 105 & $\mathrm{NK}$ & 34 & 79 & 43 \\
\hline ans & $\therefore 1,439: 1$ & NR & $190209: 3$ & $824: 2$ & $1:-445$ \\
\hline EDTA & $\therefore \mathrm{NR} \quad \mathrm{X}$ & $\mathrm{NR}$ & NR & NR & $A$ NR \\
\hline $\mathrm{NH}_{3}$ & $\mathrm{NR}^{\prime 3}$ & $\mathrm{NR}$ & $\mathrm{NR}^{\prime}, \cdots$ & $\mathrm{NR}$ & NR \\
\hline $\mathrm{Cr}^{+6}$ & NR & N & NR & $\mathrm{N}$ & R \\
\hline $\mathrm{CN}^{-}$ & $\mathrm{NR}$ & $\mathrm{NR}$ & NR & NR & $\mathrm{NR}$ \\
\hline $\mathrm{H}_{2} \mathrm{O}$ & 351,500 & 343,000 & 402,000 & 374,625 & 202,463 \\
\hline $\begin{array}{l}\text { SMMA1 } \\
\text { Volume (L) }\end{array}$ & 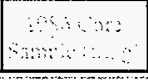 & $\therefore \ldots$ & & & 361,500 \\
\hline \multicolumn{6}{|c|}{ S $\mathrm{HDW}=$ Hanford Defined Waste } \\
\hline \multicolumn{6}{|c|}{$\begin{array}{l}\text { NR } \quad \text { Not reported } \\
\text { Based on the TCR (Morris 1996) } \\
\text { Based-on mean of two composite core samples from tank } 241-\mathrm{A}-103 \text { (Weiss and Schull } \\
\text { 1988b) }\end{array}$} \\
\hline \multicolumn{6}{|c|}{$\begin{array}{l}\text { of Based on } 361,500 \text { L (95.5 kgal) of SMMAl saltcake, with an average density of } 1.495 \\
\mathrm{~kg} \text { L. This estimate was derived by averaging the core and auger sample results for tank } \\
\text { 241-A-102, and then averaging the results for tanks } 241-\mathrm{A}-102 \text { and } 241-\mathrm{A}-103 \text {. }\end{array}$} \\
\hline
\end{tabular}


(formaliy known as)

Table 5. Analytical Results and Tank Inventory Estimates for Radioactive Components in SMMA1 Saltcake in Tank 241-AX-103 Based on Core Samples from Tanks 241-A-102 and 241-A-103

\begin{tabular}{|c|c|c|c|c|c|}
\hline \multirow{2}{*}{ Analyte } & \multicolumn{2}{|c|}{ Tank 241-A-102 Sample Data } & \multirow{2}{*}{$\begin{array}{c}\text { Tank } \\
241-\mathrm{A}-103 \\
\text { Core Sample } \\
\text { Data } \\
(\mu \mathrm{Ci} / \mathrm{g}) \\
\end{array}$} & \multirow{2}{*}{$\begin{array}{c}\text { Average Analyte } \\
\text { Concentration in } \\
\text { SMMA1 Saltcake } \\
(\mu \mathrm{Ci} / \mathrm{g})\end{array}$} & \multirow{2}{*}{$\begin{array}{c}\text { Estimated } \\
\text { Inventory of } \\
\text { SMMAI Saltcake } \\
\text { in Tank } \\
241-\mathrm{AX}-103(\mathrm{C}) \\
\end{array}$} \\
\hline & $\begin{array}{l}1986 \text { Core } \\
\text { Sample }(\mu \mathrm{Ci} / \mathrm{g})^{\mathrm{a}}\end{array}$ & $\begin{array}{c}1996 \text { Auger } \\
\text { Sample }(\mu \mathrm{Ci} / \mathrm{g})^{b}\end{array}$ & & & \\
\hline Decay Date & $12 / 31 / 99$ & $12 / 31 / 99$ & $12 / 31 / 99$ & $12 / 31 / 99$ & $12 / 31 / 99$ \\
\hline${ }^{14} \mathrm{C}$ & 1 & $\mathrm{NR}$ & 0.0026 & $0.0019 \ldots$ & 1.004 \\
\hline${ }^{60} \mathrm{Co}$ & 0.137 & $\mathrm{NR}$ & 0.015 & 0.076 & 40.95 \\
\hline${ }^{90} \mathrm{Sr}$. & 436 & NR & 35.2 & 236 & 127,296 \\
\hline${ }^{90} \mathrm{Y}$ & 436 & $\mathrm{NR}$ & 35.2 & 236 & 296 \\
\hline${ }^{99} \mathrm{Tc}$ & 0.100 & $\mathrm{NR}$ & 0.117 & 0.109 & 58.7 \\
\hline${ }^{129} \mathrm{I}$ & 0.000039 & NR. & 0.000019 & -05 & 0.016 \\
\hline${ }^{137} \mathrm{Cs}$ & 101.8 & $\mathrm{NR}$ & 147 & 124 & 67,284 \\
\hline${ }^{137} \mathrm{mBa}$ & 96.3 & $\mathrm{NR}$ & 139 & 118 & 63,650 \\
\hline${ }^{239 / 240} \mathrm{Pu}$ & 2.001 & NR & 0.130 & 1.065 & 576 \\
\hline${ }^{241} \mathrm{Am}$ & 1185 & $\mathrm{NR}$ & 0.119 & 0.652 & 352 \\
\hline \multicolumn{6}{|c|}{ 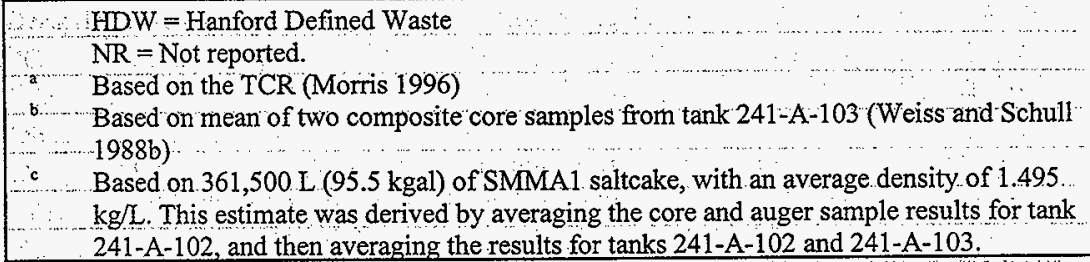 } \\
\hline
\end{tabular}


Table 6. Best-Basis Nonradiological Inventory Before Retrieval of Waste from Single-Shell Tank 241-AX-103 (page 1 of 2)

\begin{tabular}{|c|c|c|c|}
\hline$\ldots \ldots$ & Sludge & Saltcake & Overall \\
\hline Density $\left(\mathrm{kg} / \mathrm{m}^{3}\right)$ & $1 ; 800: 0$ & $\cdots \quad 1,495: 0$ & $1,540.0$ \\
\hline Volume $\left(\mathrm{m}^{3}\right)$ & $\cdots \cdot 625$ & 361.5 & 424.0 \\
\hline \multicolumn{2}{|l|}{ Components (M) } & $\ldots \ldots \ldots \ldots$ & Inventory $(\mathrm{kg})$ \\
\hline $\mathrm{Ag}$ & $\mathrm{NR}$ & $2: 31 \mathrm{E}-03$ & $90.2 \ldots$ \\
\hline $\mathrm{Al}$ & $2: 48 \mathrm{E}+00$ & $1.22 \mathrm{E}+00$ & $16,086: 0 \ldots$ \\
\hline As $\cdots \cdots$ & $\cdots \quad \mathrm{NR}$ & $\mathrm{NR}$ & $\mathrm{NR}^{\prime}$ \\
\hline $\mathrm{B}$ & NR & $2.52 \mathrm{E}-03$ & 9.8 \\
\hline $\mathrm{Ba}$ & $2.10 \mathrm{E}-02$ & $5.91 \mathrm{E}-03$ & 473.8 \\
\hline $\mathrm{Bi}$ & NR & $4.34 \mathrm{E}-03$ & 327.9 \\
\hline $\mathrm{Ca}$ & $6.41 \mathrm{E}-01$ & $6.26 \mathrm{E}-02$ & $2,515.2$ \\
\hline $\mathrm{Cd}$ & $1.50 \mathrm{E}-02$ & $9.61 \mathrm{E}-04$ & 144.5 \\
\hline $\mathrm{Cl}$ & $1.79 \mathrm{E}-02$ & $1.96 \mathrm{E}-01$ & $2,549.6$ \\
\hline TIC as $\mathrm{CO}_{3}$ & $\mathrm{NR}$ & 5.41.E-01 & $11,727.6$ \\
\hline $\mathrm{Cr}$ & $6.10 \mathrm{E}-02$ & $1.23 \mathrm{E}-01$ & $2 ; 513.1$ \\
\hline $\mathrm{Cu}$ & $\mathrm{NR}$ & $1,11 \mathrm{E}-03$ & 25.5 \\
\hline E: & $\mathrm{NR}$ & $2.18 \mathrm{E}-02$ & 149.7 \\
\hline $\mathrm{Ee}$ & $5.31 \mathrm{E}+00$ & $2.29 \mathrm{E}-01$ & $23,176.0$ \\
\hline $\mathrm{Hg}$ & NR & $8.12 \mathrm{E}-06$ & 0.6 \\
\hline $\mathrm{K}$ & NR & $1.05 \mathrm{E}-01$ & $1,481.2$ \\
\hline $\mathrm{La}$ & $\mathrm{NR}$ & 1.11E-03 & 55.7 \\
\hline $\mathrm{Mg}$ & $1.71 \mathrm{E}-01$ & $6.70 \mathrm{E}-02$ & 848.2 \\
\hline $\mathrm{Mn}$ & $1.16 \mathrm{E}-01$ & $3.93 \mathrm{E}-02$ & $1,180.2$ \\
\hline $\mathrm{Na}$ & $3.33 \mathrm{E}+00$ & $1.19 \mathrm{E}+01$ & $103,854.8$ \\
\hline Ni: & $2.60 \mathrm{E}-01$ & $7.17 \mathrm{E}-03$ & $1,106.7$ \\
\hline $\mathrm{NO}_{2}$ & $8.30 \mathrm{E}-02$ & $2.70 \mathrm{E}+00$ & $45,203.7$ \\
\hline $\mathrm{NO}_{3}$ & $\mathrm{NR}$ & $2.99 \mathrm{E}+00$ & $66,987.8$ \\
\hline $\mathrm{OH}$ & $1.56 \mathrm{E}+01$ & NR & $16,595.4$ \\
\hline $\mathrm{Pb}$ & $\mathrm{NR}$ & $5.99 \mathrm{E}-03$ & 449.0 \\
\hline $\mathrm{P}$ as $\mathrm{PO}_{4}$ & $1.10 \mathrm{E}-01$ & $1.35 \mathrm{E}-01$ & $5,284.5$ \\
\hline $\mathrm{P}$ & $1.10 \mathrm{E}-01$ & $1.79 \mathrm{E}-01$ & $2,215.0$ \\
\hline $\mathrm{Se}$ & NR & NR & NR \\
\hline Si as SiO & $2.48 \mathrm{E}+00$ & $5.66 \mathrm{E}-01$ & $27,398.5$ \\
\hline $\mathrm{S}$ as $\mathrm{SO}_{4}$ & $1.35 \mathrm{E}-01$ & $6.97 \mathrm{E}-02$ & $3,232.3$ \\
\hline $\mathrm{S}$ & $1.35 \mathrm{E}-01$ & $\mathrm{NR}$ & 270.7 \\
\hline $\mathrm{Sr}$ & NR & $6.53 \mathrm{E}-04$ & 20.7 \\
\hline TOC & $\mathrm{NR}$ & $1.19 \mathrm{E}+00$ & $5,159.9$ \\
\hline Total U & $1.23 \mathrm{E}-03$ & $6.16 \mathrm{E}-02$ & $5,316.0$ \\
\hline
\end{tabular}


Table 6. Best-Basis Nonradiological Inventory Before Retrieval $\mathrm{d}_{\mathrm{f}}$ known as) Waste from Single-Shell Tank 241-AX-103 (page 2 of 2)

\begin{tabular}{|l|c|r|r|}
\hline & \multicolumn{1}{|c|}{ Sludge } & \multicolumn{1}{|c|}{ Saltcake } & Overall \\
\hline Density $\left(\mathrm{kg} / \mathrm{m}^{3}\right)$ & $1,800.0$ & $1,495.0$ & $1,540: 0$ \\
\hline Volume $\left(\mathrm{m}^{3}\right)$ & 62.5 & 361.5 & 424.0 \\
\hline Components $(\mathrm{M})$ & & & Inventory $(\mathrm{kg})$ \\
\hline $\mathrm{Zn}$ & $\mathrm{NR}$ & $1.82 \mathrm{E}-03$ & 42.9 \\
\hline $\mathrm{Zr}$ & $\mathrm{NR}$ & $1.35 \mathrm{E}-02$ & 445.3 \\
\hline $\mathrm{EDTA}$ & $\mathrm{NR}$ & $2.63 \mathrm{E}-02$ & $2,780.0$ \\
\hline $\mathrm{NH}_{3}$ & $2.28 \mathrm{E}-01$ & $4.87 \mathrm{E}-02$ & 543.0 \\
\hline $\mathrm{Cr}^{+6}$ & $\mathrm{NR}$ & $\mathrm{NR}$ & $\mathrm{NR}$ \\
\hline $\mathrm{CN}^{2}$ & $\mathrm{NR}$ & $\mathrm{NR}$ & $\mathrm{NR}$ \\
\hline $\mathrm{H}_{2} \mathrm{O}$ & $4.10 \mathrm{E}+01$ & $3.11 \mathrm{E}+01$ & $2.49 \mathrm{E}+05$ \\
\hline Total & & & $5.99 \mathrm{E}+05$ \\
\hline
\end{tabular}


Table 7. Best-Basis Radiological Inventory Before Retrieval of Waste From Single-Shell Tank 241-AX-103 (page 1 of 2)

\begin{tabular}{|c|c|c|c|}
\hline Components $(\mathrm{Ci} / \mathrm{L})$ & Sludge & Saltcake & Inventory $(\mathrm{Ci})$ \\
\hline Decay Date & $12 / 31 / 99$ & $12 / 31 / 99$ & $12 / 31 / 99$ \\
\hline${ }^{3} \mathrm{H}$ & $1.08 \mathrm{E}-04$ & $2.02 \mathrm{E}-04$ & $7.98 \mathrm{E}+01$ \\
\hline${ }^{14} \mathrm{C}$ & NR & $2.78 \mathrm{E}-06$ & $1.00 \mathrm{E}+00$ \\
\hline${ }^{59} \mathrm{Ni}$ & $9.99 \mathrm{E}-05$ & $1.62 \mathrm{E}-06$ & $6.84 \mathrm{E}+00$ \\
\hline${ }^{60} \mathrm{Co}$ & $5.94 \mathrm{E}-03$ & $1.13 \mathrm{E}-04$ & $4.13 E+02$ \\
\hline${ }^{63} \mathrm{Ni}$ & $1.00 \mathrm{E}-02$ & $1.60 \mathrm{E}-04$ & $6.85 \mathrm{E}+02$ \\
\hline${ }^{79} \mathrm{Se}$ & $9.45 \mathrm{E}-05$ & $3.13 \mathrm{E}-06$ & $7.04 \mathrm{E}+00$ \\
\hline${ }^{90} \mathrm{Sr}$ & $5.15 \mathrm{E}+01$ & $3.52 \mathrm{E}-01$ & $3.35 E+06$ \\
\hline${ }^{90} \mathrm{Y}$ & $5.15 \mathrm{E}+01$ & $3.52 \mathrm{E}-01$ & $3.35 \mathrm{E}+06$ \\
\hline${ }^{93} \mathrm{mNb}$ & $3.26 \mathrm{E}-04$ & $1.11 \mathrm{E}-05$ & $2.44 \mathrm{E}+01$ \\
\hline${ }^{93} \mathrm{Zr}$ & $4.33 \mathrm{E}-04$ & $1.54 \mathrm{E}-05$ & $3.27 \mathrm{E}+01$ \\
\hline${ }^{99} \mathrm{Tc} \cdot 3 \mathrm{C}$ & $\mathrm{NR}$ & $1.62 \mathrm{E}-04$ & $5.87 \mathrm{E}+01$ \\
\hline${ }^{106} \mathrm{Ru}$ & $3.23 \mathrm{E}-07$ & 7.22E-09 & $2.28 \mathrm{E}-02$ \\
\hline${ }^{113} \mathrm{mCd}$ & $1.85 \mathrm{E}-03$ & $8.41 \mathrm{E}-05$ & $1.46 \mathrm{E}+02$ \\
\hline${ }^{125} \mathrm{Sb}$ & 2.37E-03 & NR : & $1.48 \mathrm{E}+02$ \\
\hline${ }^{126} \mathrm{Sn}$ & $1.47 \mathrm{E}-04$ & $4.73 \mathrm{E}-06$ & $1.09 \mathrm{E}+01$ \\
\hline${ }^{129} \mathrm{I}$ & NR & $4.34 \mathrm{E}-08$ & $1.57 \mathrm{E}-02$ \\
\hline${ }^{134} \mathrm{Cs}$ & $6.62 \mathrm{E}-06$ & $3.29 \mathrm{E}-06$ & $1.60 \mathrm{E}+00$ \\
\hline${ }^{135} \mathrm{Cs}$ & NR & $\mathrm{NR}$ & $\mathrm{NR}$ \\
\hline${ }^{137} \mathrm{Cs}$ & $1.07 \mathrm{E}+00$ & $1.86 \mathrm{E}-01$ & $1.34 \mathrm{E}+05$ \\
\hline${ }^{137} \mathrm{mBa}$ & $1.01 \mathrm{E}+00$ & $1.76 \mathrm{E}-01$ & $1.27 \mathrm{E}+05$ \\
\hline${ }^{151} \mathrm{Sm}$ & $3.52 \mathrm{E}-01$ & $1.10 \mathrm{E}-02$ & $2.60 \mathrm{E}+04$ \\
\hline${ }^{152} \mathrm{Eu}$ & $1.08 \mathrm{E}-04$ & $4.09 \mathrm{E}-06$ & $8.21 \mathrm{E}+00$ \\
\hline${ }^{154} \mathrm{Eu}$ & $4.34 \mathrm{E}-02$ & $\mathrm{NR}$ & $2.7 .1 \mathrm{E}+03$ \\
\hline${ }^{155} \mathrm{Eu}$ & $2.79 \mathrm{E}-02$ & $\mathrm{NR}$ & $1.74 \mathrm{E}+03$ \\
\hline${ }^{226} \mathrm{Ra}$ & $6.27 \mathrm{E}-09$ & $1.21 \mathrm{E}-10$ & $4.36 \mathrm{E}-04$ \\
\hline${ }^{227} \mathrm{AC}$ & $3.37 \mathrm{E}-08$ & $7.47 \mathrm{E}-10$ & $2.38 \mathrm{E}-03$ \\
\hline${ }^{228} \mathrm{Ra}$ & $5.68 \mathrm{E}-14$ & $3.15 \mathrm{E}-07$ & $1.14 \mathrm{E}-01$ \\
\hline${ }^{229} \mathrm{Th}$ & $8.86 \mathrm{E}-12$ & $7.33 \mathrm{E}-09$ & $2.65 \mathrm{E}-03$ \\
\hline${ }^{231} \mathrm{~Pa}$ & $7.61 \mathrm{E}-08$ & $3.57 \mathrm{E}-09$ & $6.05 \mathrm{E}-03$ \\
\hline${ }^{232} \mathrm{Th}$ & $5.12 \mathrm{E}-15$ & $3.40 \mathrm{E}-08$ & $1.23 \mathrm{E}-02$ \\
\hline${ }^{232} \mathrm{U}$ & $7.11 \mathrm{E}-12$ & $9.43 \mathrm{E}-07$ & $3.41 \mathrm{E}-01$ \\
\hline${ }^{233} \mathrm{U}:$ & $1.68 \mathrm{E}-13$ & $3.62 \mathrm{E}-06$ & $1.31 \mathrm{E}+00$ \\
\hline${ }^{234} \mathrm{U}$ & $8.76 \mathrm{E}-08$ & $5.98 \mathrm{E}-07$ & $2.21 \mathrm{E}-01$ \\
\hline${ }^{235} \mathrm{U}$ & $3.66 \mathrm{E}-09$ & $2.37 \mathrm{E}-08$ & $8.81 \mathrm{E}-03$ \\
\hline${ }^{236} \mathrm{O}$ & $2.40 \mathrm{E}-09$ & $1.93 \mathrm{E}-08$ & $7.11 \mathrm{E}-03$ \\
\hline${ }^{237} \mathrm{Ng}$ & $3.05 \mathrm{E}-07$ & $8.33 \mathrm{E}-07$ & $3.20 \mathrm{E}-01$ \\
\hline
\end{tabular}


Table 7. Best-Basis Radiological Inventory Before Retrieval of Waste From Single-Shell Tank 241-AX-103 (page 2 of 2)

\begin{tabular}{|c|c|c|c|}
\hline Components (Ci/L) & Sludge & Saltcake & Inventory $(\mathrm{Ci})$ \\
\hline Decay Date & $12 / 31 / 99$ & $12 / 31 / 99$ & $12 / 31 / 99$ \\
\hline${ }^{238} \mathrm{P}_{11}$ & $7.99 \mathrm{E}-05$ & $1.25 \mathrm{E}-06$ & $5.45 \mathrm{E}+00$ \\
\hline${ }^{238} \mathrm{U}$ & $8.54 \mathrm{E}-08$ & $8.30 \mathrm{E}-07$ & 3.05E-01 \\
\hline${ }^{239} \mathrm{Pu}$ & $2.06 \mathrm{E}-03$ & $4.09 \mathrm{E}-05$ & $1.44 \mathrm{E}+02$ \\
\hline${ }^{240} \mathrm{Pu}$ & $3.95 \mathrm{E}-04$ & $7.08 \mathrm{E}-06$ & $2.73 \mathrm{E}+01$ \\
\hline $239 / 240 \mathrm{Pu}$ & $1.32 \mathrm{E}-02$ & $1.59 \mathrm{E}-03$ & $1.40 \mathrm{E}+03$ \\
\hline${ }^{241} \mathrm{Am}$ & NR & 9.75E-04 & $3.52 \mathrm{E}+02$ \\
\hline${ }^{241} \mathrm{Pu}$ & $5.69 \mathrm{E}-03$ & $8.66 \mathrm{E}-05$ & $3.87 \mathrm{E}+02$ \\
\hline${ }^{242} \mathrm{Cm} \quad \cdots$ & $2.97 \mathrm{E}-06$ & 1.37E-07: & $2.36 \mathrm{E}-01$ \\
\hline${ }^{242} \mathrm{mAm}$ & NR & $\mathrm{NR}$ & NR \\
\hline${ }^{242} \mathrm{Pu}: \cdots$ & $3: 29 \mathrm{E}-08$ & $4.76 \mathrm{E}-10$ & $2.23 \mathrm{E}-03$ \\
\hline${ }^{243} \mathrm{Am} \quad \mathrm{C}$ & $9.98 \mathrm{E}-08$ & $2.06 \mathrm{E}-09$ & $6.98 \mathrm{E}-03$ \\
\hline${ }^{243} \mathrm{Cm}$ & $2.29 \mathrm{E}-07$ & $1.28 \mathrm{E}-08$ & 1:89E-02 \\
\hline${ }^{244} \mathrm{Cm}$ & $7.02 \mathrm{E}-06$ & $1.11 \mathrm{E}-07$ & $4.79 \mathrm{E}-01$ \\
\hline Tótal & & 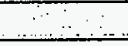 & $6.99 \mathrm{E}+06$ \\
\hline
\end{tabular}


Table 8. Retrieval Scenario Summary of Residual Waste and Fractional Removal

\begin{tabular}{|l|r|r|r|}
\hline & Case I & Case II & Case III \\
\hline Vol Base $\left(\mathrm{m}^{3}\right)$ & 101.94 & 10.19 & 1.02 \\
\hline$\%$ Base & $90.0 \%$ & $99.0 \%$ & $99.9 \%$ \\
\hline Target $\left(\mathrm{m}^{3}\right)$ & 101.94 & 10.19 & 1.02 \\
\hline Sludge $\left(\mathrm{m}^{3}\right)$ & 62.55 & 10.19 & 1.02 \\
\hline Saltcake $\left(\mathrm{m}^{3}\right)$ & 39.39 & 0.00 & 0.00 \\
\hline Sludge Removal & $0.0 \%$ & $83.7 \%$ & $98.4 \%$ \\
\hline Saltcake Removal & $89.1 \%$ & $100.0 \%$ & $100.0 \%$ \\
\hline
\end{tabular}

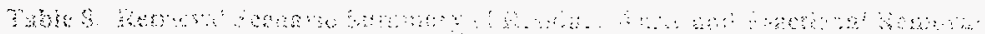

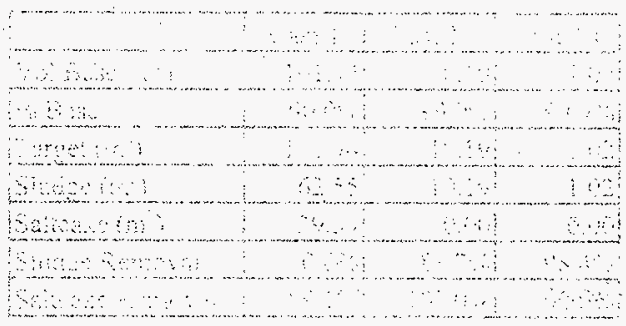


(formally known as)

Table 9. Tank 241-AX-103 Nonradiological Waste Residual Inventory Following Retrieval (page 1 of 2)

\begin{tabular}{|c|c|c|c|}
\hline Residual Waste (kg) & Case I & Case II & Case III \\
\hline Target $\left(\mathrm{m}^{3}\right)$ & 101.94 & 10.19 & 1.02 \\
\hline Sludge $\left(\mathrm{m}^{3}\right)$ & 62.55 & 10.19 & 1.02 \\
\hline Saltcake $\left(\mathrm{m}^{3}\right)$ & 39.39 & 0.00 & 0.00 \\
\hline $\mathrm{Ag}$ & $9.83 \mathrm{E}+00$ & 0 & 0 \\
\hline $\mathrm{Al}$ & $5.48 \mathrm{E}+03$ & $6.82 \mathrm{E}+02$ & $6.82 \mathrm{E}+01$ \\
\hline As & NR & NR & NR \\
\hline$B$ & $1.07 \mathrm{E}+00$ & 0 & 0 \\
\hline $\mathrm{Ba}$ & $2.12 \mathrm{E}+02$ & $2.94 \mathrm{E}+01$ & $2.94 \mathrm{E}+00$ \\
\hline $\mathrm{Bi}$ & $3.57 \mathrm{E}+01$ & 0 & 0 \\
\hline $\mathrm{Ca}$ & $1.71 \mathrm{E}+03$ & $2.62 \mathrm{E}+02$ & $2.62 \mathrm{E}+01$ \\
\hline $\mathrm{Cd}$ & $1.10 \mathrm{E}+02$ & $1.72 \mathrm{E}+01$ & $1.72 \mathrm{E}+00$ \\
\hline $\mathrm{Cl}$ & $3.13 \mathrm{E}+02$ & $6.45 \mathrm{E}+00$ & $6.45 \mathrm{E}-01$ \\
\hline $\mathrm{TIC}$ as $\mathrm{CO}_{3}$ & $1.28 \mathrm{E}+03$ & 0 & 0 \\
\hline $\mathrm{Cr}$. & $4.51 \mathrm{E}+02$ & $3.23 E+01$ & $3.23 \mathrm{E}+00$ \\
\hline $\mathrm{Cu}$ & $2.78 \mathrm{E}+00$ & 0 & 0 \\
\hline $\mathrm{F}$ & $1.63 \mathrm{E}+01$ & 0 & 0 \\
\hline Fe & $1.91 \mathrm{E}+04$ & $3.02 \mathrm{E}+03$ & $3.02 \mathrm{E}+02$ \\
\hline $\mathrm{Hg}$ & $6.42 \mathrm{E}-02$ & 0 & 0 \\
\hline $\mathrm{K}$ & $1.61 \mathrm{E}+02$ & 0 & 0 \\
\hline $\mathrm{La}$ & $6.07 \mathrm{E}+00$ & 0 & 0 \\
\hline $\mathrm{Mg}$ & $3.24 \mathrm{E}+02$ & $4.24 \mathrm{E}+01$ & $4.24 \mathrm{E}+00$ \\
\hline $\mathrm{Mn}$ & $4.84 \mathrm{E}+02$ & $6.51 \mathrm{E}+01$ & $6.51 \mathrm{E}+00$ \\
\hline $\mathrm{Na}$ & $1.56 \mathrm{E}+04$ & $7.80 \mathrm{E}+02$ & $7.80 \mathrm{E}+01$ \\
\hline $\mathrm{Ni}$ & $9.71 \mathrm{E}+02$ & $1.56 \mathrm{E}+02$ & $1.56 \mathrm{E}+01$ \\
\hline $\mathrm{NO}_{2}$ & $5.14 \mathrm{E}+03$ & $3.89 \mathrm{E}+01$ & $3.89 \mathrm{E}+00$ \\
\hline $\mathrm{NO}_{3}$ & $7.30 \mathrm{E}+03$ & 0 & 0 \\
\hline $\mathrm{OH}^{-}$ & $1.66 \mathrm{E}+04$ & $2.70 \mathrm{E}+03$ & $2.70 \mathrm{E}+02$ \\
\hline $\mathrm{Pb}$ & $4.89 \mathrm{E}+01$ & 0 & 0 \\
\hline 2 as $\mathrm{PO}_{4}$ & $1.16 \mathrm{E}+03$ & $1.06 \mathrm{E}+02$ & $1.06 \mathrm{E}+01$ \\
\hline $\mathrm{P}$ & $4.31 \mathrm{E}+02$ & $3.47 \mathrm{E}+01$ & $3.47 \mathrm{E}+00$ \\
\hline $\mathrm{Se}$ & NR & NR & NR \\
\hline Si as $\mathrm{SiO}_{3}$ & $1.35 \mathrm{E}+04$ & $1.93 \mathrm{E}+03$ & $1.93 \mathrm{E}+02$ \\
\hline $\mathrm{S}$ as $\mathrm{SO}_{4}$ & $1.07 \mathrm{E}+03$ & $1.32 \mathrm{E}+02$ & $1.32 \mathrm{E}+01$ \\
\hline$S$ & $2.71 \mathrm{E}+02$ & $4.41 \mathrm{E}+01$ & $4.41 \mathrm{E}+00$ \\
\hline $\mathrm{Sr}$ & $2.25 \mathrm{E}+00$ & 0 & 0 \\
\hline TOC & $5.62 \mathrm{E}+02$ & 0 & 0 \\
\hline Total U & $5.96 \mathrm{E}+02$ & $2.98 \mathrm{E}+00$ & $2.98 \mathrm{E}-01$ \\
\hline
\end{tabular}


HNF-SD-HTI-TI-001, REV. 0 .

Table 9. Tank 241-AX-103 Nonradiological Waste Residual Inventory Following Retrieval (page 2 of 2)

\begin{tabular}{|l|c|c|c|}
\hline Residual Waste $(\mathrm{kg})$ & Case I & Case II & Case III \\
\hline $\mathrm{Zn}$ & $4.68 \mathrm{E}+00$ & 0 & 0 \\
\hline $\mathrm{Zr}$ & $4.85 \mathrm{E}+01$ & 0 & 0 \\
\hline EDTA & $3.03 \mathrm{E}+02$ & 0 & 0 \\
\hline $\mathrm{NH}_{3}$ & $2.76 \mathrm{E}+02$ & $3.96 \mathrm{E}+01$ & $3.96 \mathrm{E}+00$ \\
\hline $\mathrm{Cr}^{+6}$ & $\mathrm{NR}$ & $\mathrm{NR}$ & $\mathrm{NR}$ \\
\hline $\mathrm{CN}$ & $\mathrm{NR}$ & $\mathrm{NR}$ & $\mathrm{NR}$ \\
\hline $\mathrm{H}_{2} \mathrm{O}$ & $6.82 \mathrm{E}+04$ & $7.52 \mathrm{E}+03$ & $7.52 \mathrm{E}+02$ \\
\hline Total & $1.61 \mathrm{E}+05$ & $1.76 \mathrm{E}+04$ & $1.76 \mathrm{E}+03$ \\
\hline
\end{tabular}

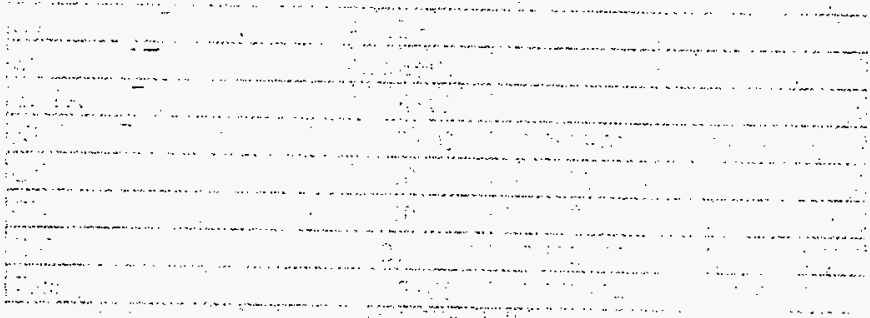


Table 10. Tank 241-AX-103 Radiological Waste Residual Inventory Following Retrieval (page 1 of 2)

\begin{tabular}{|c|c|c|c|}
\hline Residual Waste (Ci) & Case I & Case II & Case III \\
\hline Decay Date & $12 / 31 / 99$ & $12 / 31 / 99$ & $12 / 31 / 99$ \\
\hline${ }^{3} \mathrm{H}$ & $1.47 \mathrm{E}+01$ & $1.10 E+00$ & $1.10 \mathrm{E}-01$ \\
\hline${ }^{14} \mathrm{C}$ & $1.09 \mathrm{E}-01$ & 0. & 0 \\
\hline${ }^{59} \mathrm{Ni}$ & $6.31 E+00$ & $1.02 \mathrm{E}+00$ & $1.02 \mathrm{E}-01$ \\
\hline${ }^{60} \mathrm{Co}$ & $3.76 \mathrm{E}+02$ & $6.06 \mathrm{E}+0.1$ & $6.06 \mathrm{E}+00$ \\
\hline${ }^{63} \mathrm{Ni}$ & $6.33 \mathrm{E}+02$ & $1.02 E+02$ & $1.02 \mathrm{E}+01$ \\
\hline${ }^{79} \mathrm{Se}$ & $6.03 E+00$ & 9.63E-01 & $9.63 \mathrm{E}-02$ \\
\hline${ }^{90} \mathrm{Sr}$ & $3.24 \mathrm{E}+06$ & $5.25 \mathrm{E}+05$ & $5.25 \mathrm{E}+04$ \\
\hline${ }^{90} \mathrm{Y}$ & $3.24 \mathrm{E}+06$ & $5.25 \mathrm{E}+05$ & $5.25 E+04$ \\
\hline $93 \mathrm{mNb}$ & $2.08 \mathrm{E}+01$ & $3.32 \mathrm{E}+00$ & $3.32 \mathrm{E}-01$ \\
\hline $\begin{array}{|lll|}{ }^{93} \mathrm{Zr} & \\
\end{array}$ & $2.77 \mathrm{E}+01$ & $4.42 \mathrm{E}+00$ & $4.42 \mathrm{E}-01$ \\
\hline${ }^{99} \mathrm{Tc}:$ & $6.40 \mathrm{E}+00$ & 0 & 0 \\
\hline${ }^{106} \mathrm{Ru}$ & $2.05 \mathrm{E}-02$ & $3.29 \mathrm{E}-03$ & $3.29 \mathrm{E}-04$ \\
\hline${ }^{113} \mathrm{mCd}$ & $1.19 \mathrm{E}+02$ & $1.89 \mathrm{E}+01$ & $1.89 \mathrm{E}+00$ \\
\hline${ }^{125} \mathrm{Sb}$ & $1.48 \mathrm{E}+02$ & $2.41 \mathrm{E}+01$ & $2.41 \mathrm{E}+00$ \\
\hline${ }^{126} \mathrm{Sn}$ & $9.41 \mathrm{E}+00$ & $1.50 \mathrm{E}+00$ & $1.50 \mathrm{E}=01$ \\
\hline${ }^{129} \mathrm{I}$ & $1.71 \mathrm{E}-03$ & 0 & 0 \\
\hline${ }^{134} \mathrm{Cs}$ & $5.44 \mathrm{E}-01$ & $6.75 \mathrm{E}-02$ & $6.75 \mathrm{E}-03$ \\
\hline${ }^{135} \mathrm{Cs}$ & NR: & $\mathrm{NR}$ & $\mathrm{NR}$ \\
\hline${ }^{137} \mathrm{Cs}$ & $7.42 \mathrm{E}+04$ & $1.09 \mathrm{E}+04$ & $1.09 \mathrm{E}+03$ \\
\hline${ }^{137} \mathrm{mBa}$ & $7.01 E+04$ & $1.03 \mathrm{E}+04$ & $1.03 \mathrm{E}+03$ \\
\hline${ }^{151} \mathrm{Sm}$ & $2.24 \mathrm{E}+04$ & $3.59 \mathrm{E}+03$ & $3.59 \mathrm{E}+02$ \\
\hline${ }^{152} \mathrm{Eu}$ & $6.89 \mathrm{E}+00$ & $1.10 \mathrm{E}+00$ & $1.10 \mathrm{E}-01$ \\
\hline${ }^{154} \mathrm{Eu}$ & $2.71 E+03$ & $4.42 \mathrm{E}+02$ & $4.42 \mathrm{E}+01$ \\
\hline${ }^{155} \mathrm{Eu}$ & $1.74 \mathrm{E}+03$ & $2.84 \mathrm{E}+02$ & $2.84 \mathrm{E}+01$ \\
\hline${ }^{226} \mathrm{Ra}$ & $3.97 \mathrm{E}-04$ & $6.39 \mathrm{E}-05$ & $639 \mathrm{E}-06$ \\
\hline${ }^{227} \mathrm{Ac}$ & $2.14 \mathrm{E}-03$ & $3.44 \mathrm{E}-04$ & $3.44 \mathrm{E}-05$ \\
\hline${ }^{228} \mathrm{Ra}$ & $1.24 \mathrm{E}-02$ & $5.79 \mathrm{E}-10$ & $5.79 \mathrm{E}-11$ \\
\hline${ }^{229} \mathrm{Th}$ & $2.89 \mathrm{E}-04$ & $9.03 \mathrm{E}-08$ & $9.03 \mathrm{E}-09$ \\
\hline${ }^{231} \mathrm{~Pa}$ & $4.90 \mathrm{E}-03$ & $7.76 \mathrm{E}-04$ & $7.76 \mathrm{E}-05$ \\
\hline${ }^{232} \mathrm{Th}$ & $1.34 \mathrm{E}-03$ & $5.22 \mathrm{E}-11$ & $5.22 \mathrm{E}-12$ \\
\hline${ }^{232} \mathrm{U}:$ & $3.72 \mathrm{E}-02$ & $7.25 \mathrm{E}-08$ & $7.25 \mathrm{E}-0.9$ \\
\hline${ }^{233} \mathrm{U}:$ & $1.43 \mathrm{E}-01$ & $1.71 \mathrm{E}-09$ & $1.71 \mathrm{E}-10$ \\
\hline${ }^{234} \mathrm{U}$ & $2.90 \mathrm{E}-02$ & $8.93 \mathrm{E}-04$ & $8.93 \mathrm{E}-05$ \\
\hline${ }^{235} \mathrm{U}$ & $1.16 \mathrm{E}-03$ & $3.73 \mathrm{E}-05$ & $3.73 \mathrm{E}-06$ \\
\hline${ }^{236} \mathrm{U}$ & $9.08 \mathrm{E}-04$ & $2.44 \mathrm{E}-05$ & $2.44 \mathrm{E}-06$ \\
\hline $237 \mathrm{Nn}$ & $5.19 \mathrm{E}-02$ & $3,11 \mathrm{E}-03$ & $3.11 \mathrm{E}-04$ \\
\hline
\end{tabular}


Table 10. Tank 241-AX-103 Radiological Waste Refidual 1 y known as) Inventory Following Retrieval (page 2 of 2)

\begin{tabular}{|l|c|c|c|}
\hline Residual Waste (Ci) & Case I & Case II & Case III \\
\hline Decay Date & $12 / 31 / 99$ & $12 / 31 / 99$ & $12 / 31 / 99$ \\
\hline${ }^{238} \mathrm{Pu}$ & $5.05 \mathrm{E}+00$ & $8.15 \mathrm{E}-01$ & $8.15 \mathrm{E}-02$ \\
\hline${ }^{238} \mathrm{U}$ & $3.80 \mathrm{E}-02$ & $8.70 \mathrm{E}-04$ & $8.70 \mathrm{E}-05$ \\
\hline${ }^{239} \mathrm{Pu}$ & $1.31 \mathrm{E}+02$ & $2.10 \mathrm{E}+01$ & $2.10 \mathrm{E}+00$ \\
\hline${ }^{240} \mathrm{Pu}$ & $2.50 \mathrm{E}+01$ & $4.03 \mathrm{E}+00$ & $4.03 \mathrm{E}-01$ \\
\hline${ }^{2391240} \mathrm{Pu}$ & $8.87 \mathrm{E}+02$ & $1.34 \mathrm{E}+02$ & $1.34 \mathrm{E}+01$ \\
\hline${ }^{241} \mathrm{Am}$ & $3.84 \mathrm{E}+01$ & 0 & 0 \\
\hline${ }^{241} \mathrm{Pu}$ & $3.59 \mathrm{E}+02$ & $5.80 \mathrm{E}+01$ & $5.80 \mathrm{E}+00$ \\
\hline${ }^{242} \mathrm{Cm}$ & $191 \mathrm{E}-01$ & $3.03 \mathrm{E}-02$ & $3.03 \mathrm{E}-03$ \\
\hline${ }^{242} \mathrm{mAm}$ & $\mathrm{NR}$ & NR & NR \\
\hline${ }^{242} \mathrm{Pu}$ & $2.08 \mathrm{E}-03$ & $3.36 \mathrm{E}-04$ & $3.36 \mathrm{E}-05$ \\
\hline${ }^{243} \mathrm{Am}$ & $6.32 \mathrm{E}-03$ & $1.02 \mathrm{E}-03$ & $1.02 \mathrm{E}-04$ \\
\hline${ }^{243} \mathrm{Cm}$ & $1.48 \mathrm{E}-02$ & $2.33 \mathrm{E}-03$ & $2.33 \mathrm{E}-04$ \\
\hline${ }^{244} \mathrm{Cm}$ & $4.43 \mathrm{E}-01$ & $7.15 \mathrm{E}-02$ & $7.15 \mathrm{E}-03$ \\
\hline Total & $6.64 \mathrm{E}+06$ & $1.08 \mathrm{E}+06$ & $1.08 \mathrm{E}+05$ \\
\hline
\end{tabular}

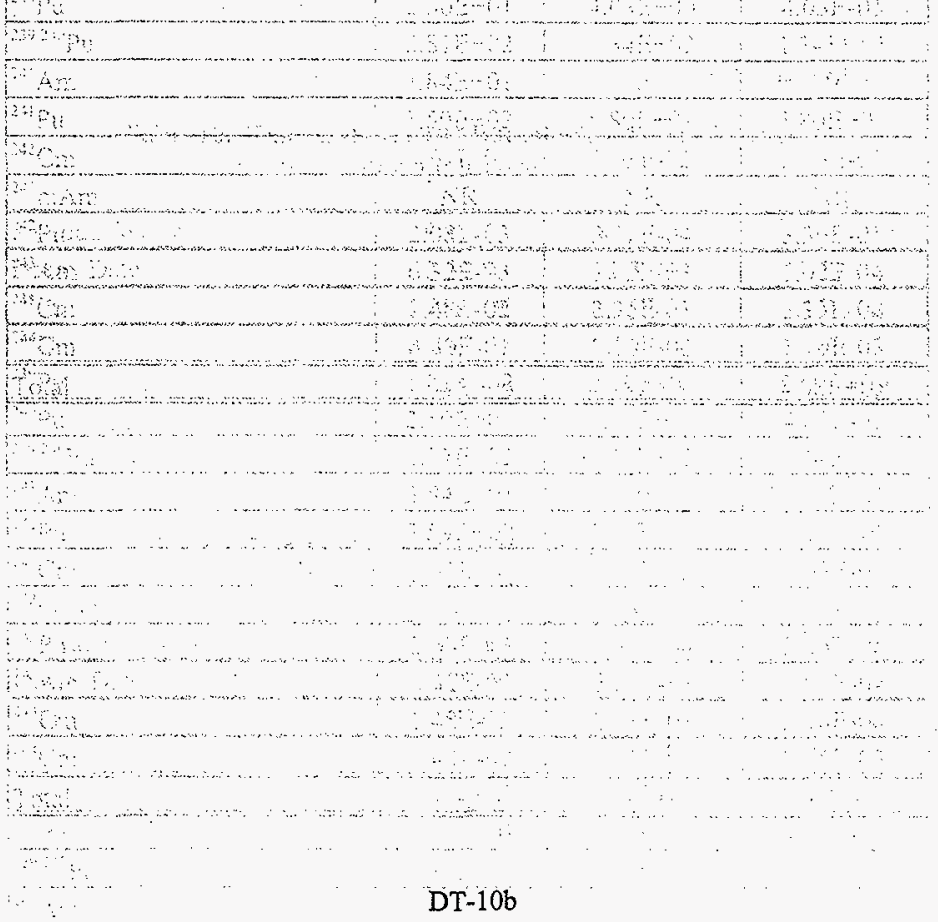


(formally known as)

Table 11. Retrieval Scenario Product Solution Non radiological Analyte Concentrations (page 1 of 2)

\begin{tabular}{|c|c|c|c|}
\hline Limiting Vol (L) & 767,953 & 896,704 & 902,809 \\
\hline Sludge [Solids Basis (L)] & 0 & 437,294 & 513,924 \\
\hline Saltcake $[\mathrm{Na}$ Basis (L)] & 767,953 & 896,704 & 902,809 \\
\hline Solution Concentrations $(\mathrm{M})$ & Case I & Case II & Case III \\
\hline $\mathrm{Ag}$ & $9.70 \mathrm{E}-04$ & $9.33 \mathrm{E}-04$ & $9.26 \mathrm{E}-04$ \\
\hline Al & $5.12 \mathrm{E}-01$ & $6.37 \mathrm{E}-01$ & $6.58 \mathrm{E}-01$ \\
\hline $\mathrm{As}$ & $\mathrm{NR}$ & $\mathrm{NR}$ & $\mathrm{NR}$ \\
\hline$B$ & $1.06 \mathrm{E}-03$ & 1.02E-03 & $1.01 \mathrm{E}-03$ \\
\hline $\mathrm{Ba}$ & $2.48 \mathrm{E}-03$ & $3.61 \mathrm{E}-03$ & $3.80 \mathrm{E}-03$ \\
\hline $\mathrm{Bi}$ & $182 \mathrm{E}-03$ & $1.75 \mathrm{E}-03$ & $1.74 \mathrm{E}-03$ \\
\hline $\mathrm{Ca}$ & $2.63 \mathrm{E}-02$ & $6.27 \mathrm{E}-02$ & $6.88 \mathrm{E}-02$ \\
\hline $\mathrm{Cd}$ & $4.03 \mathrm{E}-04$ & $1.26 \mathrm{E}-03$ & $1.41 \mathrm{E}-03$ \\
\hline $\mathrm{Cl} \ldots \mathrm{m}$ & $8.21 \mathrm{E}-02$ & $8.00 \mathrm{E}-02$ & $7.96 \mathrm{E}-02$ \\
\hline $\mathrm{TIC}$ as $\mathrm{CO}_{3}$ & $2.27 \mathrm{E}-01$ & $2.18 \mathrm{E}-01$ & $2.16 \mathrm{E}-01$ \\
\hline $\mathrm{Cr}$ & $5.17 \mathrm{E}-02$ & $5.32 \mathrm{E}-02$ & $5.35 \mathrm{E}-02$ \\
\hline $\mathrm{Cu}$ & $4.65 \mathrm{E}-0.4$ & $4.47 \mathrm{E}-04$ & $4.44 \mathrm{E}-04$ \\
\hline $\mathrm{F}$ & $9.14 \mathrm{E}-03$ & $8.79 \mathrm{E}-03$ & $8.73 \mathrm{E}-03$ \\
\hline Fe & $9.61 \mathrm{E}-02$ & $4.02 \mathrm{E}-01$ & $4.54 \mathrm{E}-01$ \\
\hline $\mathrm{Hg}$ & $3.41 \mathrm{E}-06$ & 3.27E-06 & $3.25 \mathrm{E}-06$ \\
\hline $\mathrm{K}$ & $4.40 \mathrm{E}-02$ & $4.22 \mathrm{E}-02$ & $4.20 \mathrm{E}-02$ \\
\hline $\mathrm{Ea}$ & $4.65 \mathrm{E}-04$ & $4.47 \mathrm{E}-04$ & $4.44 \mathrm{E}-04$ \\
\hline $\mathrm{Mg}$ & $2.81 \mathrm{E}-02$ & $3.70 \mathrm{E}-02$ & $3.85 \mathrm{E}-02$ \\
\hline Mn & $1.65 \mathrm{E}-02$ & $2.26 \mathrm{E}-02$ & $2.37 \mathrm{E}-02$ \\
\hline $\mathrm{Na}$ & $5.00 \mathrm{E}+00$ & $5.00 \mathrm{E}+00$ & $5.00 \mathrm{E}+00$ \\
\hline $\mathrm{Ni}$ & $3.01 \mathrm{E}-03$ & $1.81 \mathrm{E}-02$ & $2.06 \mathrm{E}=02$ \\
\hline $\mathrm{NO}_{2}$ & $1.13 \mathrm{E}+00$ & $1.09 \mathrm{E}+00$ & $1.09 \mathrm{E}+00$ \\
\hline $\mathrm{NO}_{3}$ & $1.25 \mathrm{E}+00$ & $1.20 \mathrm{E}+00$ & $1.20 \mathrm{E}+00$ \\
\hline $\mathrm{OH}$ & $\mathrm{NR}$ & $9.11 \mathrm{E}-01$ & $1.06 \mathrm{E}+00$ \\
\hline $\mathrm{Pb}$ & $2.51 \mathrm{E}-03$ & $2.42 \mathrm{E}-03$ & $2.40 \mathrm{E}-03$ \\
\hline $\mathrm{P}$ as $\mathrm{PO}_{4}$ & $5.66 \mathrm{E}-02$ & $6.08 \mathrm{E}-02$ & $6.15 \mathrm{E}-02$ \\
\hline $\mathrm{P}$ & $7.50 \mathrm{E}-02$ & $7.85 \mathrm{E}-02$ & $7.91 \mathrm{E}-02$ \\
\hline $\mathrm{Se}$ & NR & $\mathrm{NR}$ & $\mathrm{NR}$ \\
\hline $\mathrm{Si}$ as $\mathrm{SiO}_{3}$ & $2.37 \mathrm{E}-01$ & $3.73 \mathrm{E}-01$ & $3.96 \mathrm{E}-01$ \\
\hline $\mathrm{S}_{\mathrm{aS} \mathrm{SO}}$ & $2.92 \mathrm{E}-02$ & $3.60 \mathrm{E}-02$ & $3.71 \mathrm{E}-02$ \\
\hline $\mathrm{S}$ & $\mathrm{NR}$ & $7.88 \mathrm{E}-03$ & $9.20 \mathrm{E}-03$ \\
\hline $\mathrm{Sr}$ & $2.74 \mathrm{E}-04$ & $2.63 \mathrm{E}-04$ & $2.61 \mathrm{E}-04$ \\
\hline TOC & $4.98 \mathrm{E}-01$ & $4.79 \mathrm{E}-01$ & $4.76 \mathrm{E}-0 \mathrm{I}$ \\
\hline Total U & $2.58 \mathrm{E}-02$ & $2.49 \mathrm{E}-02$ & $2.47 \mathrm{E}-02$ \\
\hline
\end{tabular}


HNF-SD-HTI-TI-001, REV. 0

SESC-EN-RPT-002, Rev. 1

Table 11. Retrieval Scenario Product Solution Nonradiological (formally known as) Analyte Concentrations (page 2 of 2)

\begin{tabular}{|l|c|c|c|}
\hline Limiting Vol (L) & 767,953 & 896,704 & 902,809 \\
\hline Sludge [Solids Basis (L)] & 0 & 437,294 & 513,924 \\
\hline Saltcake [Na Basis (L)] & 767,953 & 896,704 & 902,809 \\
\hline Solution Concentrations (M) & Case I & Case II & Case III \\
\hline $\mathrm{Zn}$ & $7.61 \mathrm{E}-04$ & $7.32 \mathrm{E}-04$ & $7.27 \mathrm{E}-04$ \\
\hline $\mathrm{Zr}$ & $5.66 \mathrm{E}-03$ & $5.44 \mathrm{E}-03$ & $5.41 \mathrm{E}-03$ \\
\hline $\mathrm{EDTA}$ & $1.10 \mathrm{E}-02$ & $1.06 \mathrm{E}-02$ & $1.05 \mathrm{E}-02$ \\
\hline $\mathrm{NH}_{3}$ & $2.04 \mathrm{E}-02$ & $3.30 \mathrm{E}-02$ & $3.51 \mathrm{E}-02$ \\
\hline $\mathrm{Cr}^{+6}$ & NR & NR & NR \\
\hline $\mathrm{CN}$ & NR & NR & NR \\
\hline $\mathrm{H}_{2} \mathrm{O}$ & 13.04 & 14.92 & 15.24 \\
\hline Retrieval $\mathrm{H}_{2} \mathrm{O}$ & 32.23 & 29.89 & 29.50 \\
\hline
\end{tabular}

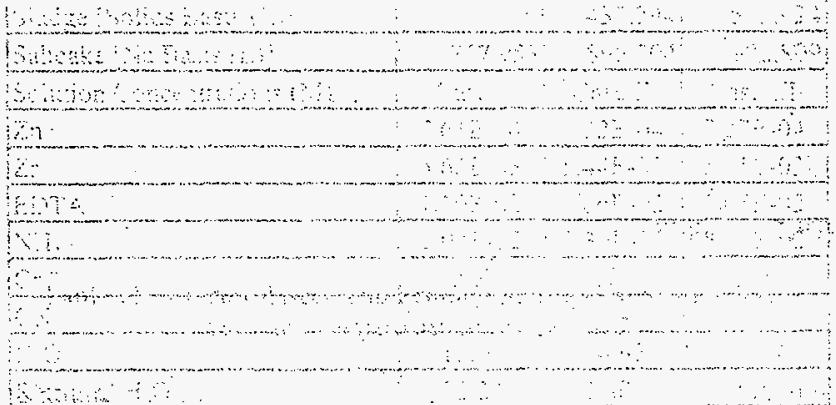


Table 12. Retrieval Scenario Product Solution Radiological Analyte Concentrations (page 1 of 2)

\begin{tabular}{|c|c|c|c|}
\hline Solution Concentrations $(\mathrm{Ci} / \mathrm{L})$ & Case I & Case II & Case III \\
\hline Decay Date & $12 / 31 / 99$ & $12 / 31 / 99$ & $12 / 31 / 99$ \\
\hline${ }^{3} \mathrm{H}$ & $8.47 \mathrm{E}-05$ & 8.77E-05 & $8.82 \mathrm{E}-05$ \\
\hline${ }^{14} \mathrm{C}$ & $1.16 \mathrm{E}-06$ & $1.12 \mathrm{E}-06$ & $1.11 E-06$ \\
\hline${ }^{59} \mathrm{Ni}$ & $6.80 \mathrm{E}-07$ & $6.49 \mathrm{E}-06$ & $7.46 \mathrm{E}-06$ \\
\hline${ }^{60} \mathrm{Co}$ & $4.75 \mathrm{E}-05$ & 3.93E-04 & $4.50 \mathrm{E}-04$ \\
\hline${ }^{63} \mathrm{Ni}$ & $6.69 \mathrm{E}-05$ & $6.50 \mathrm{E}-04$ & $7.47 \mathrm{E}-04$ \\
\hline${ }^{79} \mathrm{Se}$ & $1.31 \mathrm{E}-06$ & $6.78 \mathrm{E}-06$ & $7.69 \mathrm{E}-06$ \\
\hline${ }^{90} \mathrm{Sr}$ & 1.48E-01 & $3.15 \mathrm{E}+00$ & $3.65 \mathrm{E}+00$ \\
\hline${ }^{90} \mathrm{Y}$ & $1.48 \mathrm{E}-01$ & $3.15 \mathrm{E}+00$ & $3.65 \mathrm{E}+00$ \\
\hline${ }^{93} \mathrm{mNb}$ & $4.64 \mathrm{E}-06$ & $2.35 \mathrm{E}-05$ & $2.67 \mathrm{E}-05$ \\
\hline${ }^{93} \mathrm{Zr}$ & $6.46 \mathrm{E}-06$ & $3.15 \mathrm{E}-05$ & $3.57 \mathrm{E}-05$ \\
\hline${ }^{99} \mathrm{Tc}$ & $6.81 \mathrm{E}-05$ & $6.55 \mathrm{E}-05$ & $6.50 \mathrm{E}-05$ \\
\hline${ }^{106} \mathrm{Ru}$ & 3.03E-09 & $2.18 \mathrm{E}-08$ & $2.49 \mathrm{E}-08$ \\
\hline${ }^{113} \mathrm{mCd}$ & $3.53 \mathrm{E}-05$ & $1.42 \mathrm{E}-04$ & 1.60E-04 \\
\hline${ }^{125} \mathrm{Sb}$ & & $1.38 \mathrm{E}-04$ & $1.61 \mathrm{E}-04$ \\
\hline${ }^{126} \mathrm{Sn}$ & $1.98 \mathrm{E}-06$ & $1.05 \mathrm{E}-05$ & $1.19 \mathrm{E}-05$ \\
\hline${ }^{129} \mathrm{I}$ & $1.82 \mathrm{E}=08$ & $1.75 \mathrm{E}-08$ & $1.74 \mathrm{E}-08$ \\
\hline${ }^{134} \mathrm{Cs}$ & $1.38 \mathrm{E}-06$ & $1.71 \mathrm{E}-06$ & $1.77 \mathrm{E}-06$ \\
\hline${ }^{135} \mathrm{Cs}$ & $\mathrm{NR}$ & NR & $\mathrm{NR}$ \\
\hline${ }^{137} \mathrm{Cs}$ & $7.81 \mathrm{E}-02$ & $1.37 \mathrm{E}-01$ & $1.47 \mathrm{E}-01$ \\
\hline${ }^{137} \mathrm{mBa}$ & $7.39 \mathrm{E}-02$ & $1.30 \mathrm{E}-01$ & $1.39 \mathrm{E}-01$ \\
\hline${ }^{151} \mathrm{Sm}$ & $4.62 E-03$ & $2.50 \mathrm{E}-02$ & $2.84 \mathrm{E}-02$ \\
\hline${ }^{152} \mathrm{Eu}$ & $1.72 \mathrm{E}-06$ & $7.93 \mathrm{E}-06$ & $8.97 \mathrm{E}-06$ \\
\hline${ }^{154} \mathrm{Eu}$ & $\mathrm{NR}$ & $2.53 \mathrm{E}-03$ & $2.96 \mathrm{E}-03$ \\
\hline${ }^{155} \mathrm{Eu}$ & NR & $1.63 \mathrm{E}-03$ & $1.90 \mathrm{E}-03$ \\
\hline${ }^{226} \mathrm{Ra}$ & $5.06 \mathrm{E}-11$ & $4.15 \mathrm{E}-10$ & $4.75 \mathrm{E}-10$ \\
\hline${ }^{227} \mathrm{Ac}$ & $3.13 \mathrm{E}-10$ & $2.27 \mathrm{E}-09$ & $2.60 \mathrm{E}-09$ \\
\hline${ }^{228} \mathrm{Ra}$ & $1.32 \mathrm{E}-07$ & $1.27 \mathrm{E}-07$ & $1.26 \mathrm{E}-07$ \\
\hline${ }^{229} \mathrm{Th}$ & 3.07E-09 & $2.96 \mathrm{E}-09$ & 2:94E-09 \\
\hline${ }^{231} \mathrm{~Pa}$ & $1.50 \mathrm{E}-09$ & $5.88 \mathrm{E}-09$ & $6.62 \mathrm{E}-09$ \\
\hline${ }^{232} \mathrm{Th}$ & $1.43 \mathrm{E}-08$ & $1.37 \mathrm{E}-08$ & $1.36 \mathrm{E}-08$ \\
\hline${ }^{232} \mathrm{U}$ & $3.96 \mathrm{E}-07$ & $3.80 \mathrm{E}-07$ & $3.78 \mathrm{E}-07$ \\
\hline${ }^{233} \mathrm{U}$ & $1.52 \mathrm{E}-06$ & $1.46 \mathrm{E}-06$ & $1.45 \mathrm{E}-06$ \\
\hline${ }^{234} \mathrm{U}$ & $2.51 \mathrm{E}-07$ & $2.46 \mathrm{E}-07$ & $2.45 \mathrm{E}-07$ \\
\hline${ }^{235} \mathrm{U}$ & $9.96 \mathrm{E}-09$ & $9.78 \mathrm{E}-09$ & $9.75 \mathrm{E}-09$ \\
\hline${ }^{236} \mathrm{U}$ & $8.08 \mathrm{E}-09$ & $7.90 \mathrm{E}-09$ & $7.87 \mathrm{E}-09$ \\
\hline${ }^{237} \mathrm{~Np}$ & $3.49 \mathrm{E}-07$ & $3.54 \mathrm{E}-07$ & $3.54 \mathrm{E}-07$ \\
\hline
\end{tabular}


HNF-SD-HTI-TI-001, REV. 0

SESC-EN-RPT-002, Rev. 1

Table 12. Retrieval Scenario Product Solution Radiologral $]_{1}$ y known as) Analyte Concentrations (page 2 of 2)

\begin{tabular}{|l|c|c|c|}
\hline Solution Concentrations (Ci/L) & Case I & Case II & Case III \\
\hline Decay Date & $12 / 31 / 99$ & $12 / 31 / 99$ & $12 / 31 / 99$ \\
\hline${ }^{238} \mathrm{Pu}$ & $5.23 \mathrm{E}-07$ & $5.17 \mathrm{E}-06$ & $5.95 \mathrm{E}-06$ \\
\hline${ }^{238} \mathrm{U}$ & $3.48 \mathrm{E}-07$ & $3.40 \mathrm{E}-07$ & $3.38 \mathrm{E}-07$ \\
\hline${ }^{239} \mathrm{Pu}$ & $1.72 \mathrm{E}-05$ & $1.37 \mathrm{E}-04$ & $1.57 \mathrm{E}-04$ \\
\hline${ }^{240} \mathrm{Pu}$ & $2.97 \mathrm{E}-06$ & $2.59 \mathrm{E}-05$ & $2.97 \mathrm{E}-05$ \\
\hline${ }^{239240} \mathrm{Pu}$ & $6.68 \mathrm{E}-04$ & $1.41 \mathrm{E}-03$ & $1.54 \mathrm{E}-03$ \\
\hline${ }^{241} \mathrm{Am}$ & $4.09 \mathrm{E}-04$ & $3.93 \mathrm{E}-04$ & $3.90 \mathrm{E}-04$ \\
\hline${ }^{241} \mathrm{Pu}$ & $3.63 \mathrm{E}-05$ & $3.67 \mathrm{E}-04$ & $4.23 \mathrm{E}-04$ \\
\hline${ }^{242} \mathrm{Cm}$ & $5.77 \mathrm{E}-08$ & $2.29 \mathrm{E}-07$ & $2.58 \mathrm{E}-07$ \\
\hline${ }^{242} \mathrm{mAm}$ & NR & NR & NR \\
\hline${ }^{242} \mathrm{Pu}$ & $2.00 \mathrm{E}-10$ & $2.11 \mathrm{E}-09$ & $2.44 \mathrm{E}-09$ \\
\hline${ }^{243} \mathrm{Am}$ & $8.63 \mathrm{E}-10$ & $6.65 \mathrm{E}-09$ & $2.62 \mathrm{E}-09$ \\
\hline${ }^{243} \mathrm{Cm}$ & $5.37 \mathrm{E}-09$ & $1.85 \mathrm{E}-08$ & $2.07 \mathrm{E}-08$ \\
\hline${ }^{244} \mathrm{Cm}$ & $4.65 \mathrm{E}-08$ & $4.55 \mathrm{E}-07$ & $5.23 \mathrm{E}-07$ \\
\hline
\end{tabular}




\section{Table 13. Tank 241-AX-103 Retrieval Scenario Nonradiological Constituent Leakage Estimate (page 1 of 2)}

\begin{tabular}{|c|c|c|c|c|c|c|}
\hline $\begin{array}{l}\text { Release Volume } \\
\text { (L) }\end{array}$ & 30,283 & 30,283 & 30,283 & 151,413 & 151,413 & 151,413 \\
\hline Analyte $(\mathrm{kg})$ & Case I & Case II & Case III & Case I & Case II & Case III \\
\hline $\mathrm{Ag}$ & $3.17 \mathrm{E}+00$ & $3.05 \mathrm{E}+00$ & $3.03 \mathrm{E}+00$ & $1.58 \mathrm{E}+01$ & $1.52 \mathrm{E}+01$ & $1.51 \mathrm{E}+01$ \\
\hline $\mathrm{Al}$ & $4.18 \mathrm{E}+02$ & $5.20 \mathrm{E}+02$ & $5.37 \mathrm{E}+02$ & $2.09 E+03$ & $2.60 \mathrm{E}+03$ & $2.69 \mathrm{E}+03$ \\
\hline As & $\mathrm{NR}$ & NR & NR & $\mathrm{NR}$ & $\mathrm{NR}$ & NR \\
\hline $\mathrm{B}$ & $3.46 \mathrm{E}-01$ & $3.33 \mathrm{E}-01$ & $3.30 \mathrm{E}-01$ & $1.73 \mathrm{E}+00$ & $1.66 \mathrm{E}+00$ & $1.65 \mathrm{E}+00$ \\
\hline $\mathrm{Ba}$ & $1.03 \mathrm{E}+01$ & $1.50 E+01$ & $1.58 \mathrm{E}+01$ & $5.15 \mathrm{E}+01$ & $7.50 \mathrm{E}+01$ & $7.90 \mathrm{E}+01$ \\
\hline $\mathrm{Bi}$ & $1.15 \mathrm{E}+01$ & $1.11 \mathrm{E}+01$ & $1.10 \mathrm{E}+01$ & $5.76 \mathrm{E}+01$ & $5.54 \mathrm{E}+01$ & $5.50 \mathrm{E}+01$ \\
\hline $\mathrm{Ca}$ & $3.19 \mathrm{E}+01$ & $7.61 \mathrm{E}+01$ & $8.35 \mathrm{E}+01$ & $1.59 \mathrm{E}+02$ & $3.80 \mathrm{E}+02$ & $4.17 \mathrm{E}+02$ \\
\hline $\mathrm{Cd}$ & $1.37 \mathrm{E}+00$ & $4.30 \mathrm{E}+00$ & $4.79 \mathrm{E}+00$ & $6.86 \mathrm{E}+00$ & $2.15 \mathrm{E}+01$ & $2.40 \mathrm{E}+01$ \\
\hline$\overline{\mathrm{Cl}}$ & $8.82 \mathrm{E}+01$ & $8.59 \mathrm{E}+01$ & $8.55 \mathrm{E}+01$ & $4.41 \mathrm{E}+02$ & $4.29 \mathrm{E}+02$ & $4.27 \mathrm{E}+02$ \\
\hline $\mathrm{TIC}$ as $\mathrm{CO}_{3}$ & $4.12 \mathrm{E}+02$ & $3.96 \mathrm{E}+02$ & $3.93 \mathrm{E}+02$ & $2.06 \mathrm{E}+03$ & $1.98 \mathrm{E}+03$ & $1.97 \mathrm{E}+03$ \\
\hline $\mathrm{Cr}_{\mathrm{N}} \mathrm{Ne} / \mathrm{kg}$ & $8.13 \mathrm{E}+01$ & $8.38 \mathrm{E}+01$ & $8.42 \mathrm{E}+01$ & $4: 07 \mathrm{E}+02$ & $4.19 \mathrm{E}+02$ & $4.21 \mathrm{E}+02$ \\
\hline $\mathrm{Cu}$ & $8.95 \mathrm{E}-01$ & $8.60 \mathrm{E}-01$ & $8.54 \mathrm{E}-01$ & $4.47 \mathrm{E}+00$ & $4.30 \mathrm{E}+00$ & $4.27 \mathrm{E}+00$ \\
\hline $\overrightarrow{\mathrm{E}}$ & $5.26 \mathrm{E}+00$ & $5.06 \mathrm{E}+00$ & $5.02 \mathrm{E}+00$ & $2.63 \mathrm{E}+01$ & $2.53 \mathrm{E}+01$ & $2.51 \mathrm{E}+01$ \\
\hline $\mathrm{Fe}$ & $1.63 \mathrm{E}+02$ & $6.81 \mathrm{E}+02$ & $7.67 \mathrm{E}+02$ & $8.13 \mathrm{E}+02$ & $3.40 \mathrm{E}+03$ & $3.84 \mathrm{E}+03$ \\
\hline $\mathrm{Hg}$ & $2.07 \mathrm{E}-02$ & $1.99 \mathrm{E}-02$ & $1.98 \mathrm{E}-02$ & $1.03 \mathrm{E}-01$ & $9.95 \mathrm{E}-02$ & $9.88 \mathrm{E}-02$ \\
\hline $\mathrm{K}$ & $5,20 \mathrm{E}+01$ & $5.00 \mathrm{E}+01$ & $4.97 \mathrm{E}+01$ & $2.60 \mathrm{E}+02$ & $2.50 \mathrm{E}+02$ & $2.48 \mathrm{E}+02$ \\
\hline $\mathrm{La}$ & $1.96 \mathrm{E}+00$ & $1.88 \mathrm{E}+00$ & $1.87 \mathrm{E}+00$ & $9.78 \mathrm{E}+00$ & $9.40 \mathrm{E}+00$ & $9.34 \mathrm{E}+00$ \\
\hline $\mathrm{Mg}$ & $2.07 \mathrm{E}+01$ & $2.72 \mathrm{E}+01$ & $2.83 \mathrm{E}+0 \mathrm{i}$ & $1.03 E+02$ & $1.36 \mathrm{E}+02$ & $1.42 \mathrm{E}+02$ \\
\hline $\mathrm{Mn}$ & $2.74 \mathrm{E}+01$ & $3.77 \mathrm{E}+01$ & $3.94 \mathrm{E}+0 \mathrm{i}$ & $1.37 \mathrm{E}+02$ & $1,88 \mathrm{E}+02$ & $1.97 \mathrm{E}+02$ \\
\hline $\mathrm{Na}$ & $3.48 \mathrm{E}+03$ & $3.48 \mathrm{E}+03$ & $3,48 \mathrm{E}+03$ & $1.74 \mathrm{E}+04$ & $1.74 \mathrm{E}+04$ & $1.74 \mathrm{E}+04$ \\
\hline Ni & $5.34 \mathrm{E}+00$ & $3.21 \mathrm{E}+01$ & $3.66 \mathrm{E}+01$ & $2.67 \mathrm{E}+01$ & $1.61 \mathrm{E}+02$ & $1.83 \mathrm{E}+02$ \\
\hline $\mathrm{NO}_{2}$ & $1.58 \mathrm{E}+03$ & $1.53 \mathrm{E}+03$ & $1.52 \mathrm{E}+03$ & $7.90 \mathrm{E}+03$ & $7.63 \mathrm{E}+03$ & $7.58 \mathrm{E}+03$ \\
\hline $\mathrm{NO}_{3}$ & $2.35 \mathrm{E}+03$ & $2.26 \mathrm{E}+03$ & $2.25 \mathrm{E}+03$ & $1.18 \mathrm{E}+04$ & $1.13 \mathrm{E}+04$ & $1.12 \mathrm{E}+04$ \\
\hline $\mathrm{OH}$ & $\mathrm{NR}$ & $4.69 \mathrm{E}+02$ & $5.48 \mathrm{E}+02$ & $\mathrm{NR}$ & $2.35 \mathrm{E}+03$ & $2.74 \mathrm{E}+03$ \\
\hline $\mathrm{Pb}$ & $1.58 \mathrm{E}+01$ & $1.52 \mathrm{E}+01$ & $1.51 \mathrm{E}+01$ & $7.89 \mathrm{E}+01$ & $7.58 \mathrm{E}+01$ & $7.53 \mathrm{E}+01$ \\
\hline $\mathrm{P}$ as $\mathrm{PO}_{4}$ & $1.63 \mathrm{E}+02$ & $1.75 \mathrm{E}+02$ & $1.77 \mathrm{E}+02$ & $8.14 \mathrm{E}+02$ & $8.74 \mathrm{E}+02$ & $8.84 \mathrm{E}+02$ \\
\hline $\mathrm{P}$ & $7.03 \mathrm{E}+01$ & $7.36 \mathrm{E}+01$ & $7.42 \mathrm{E}+01$ & $3.52 \mathrm{E}+02$ & $3.68 \mathrm{E}+02$ & $3.71 \mathrm{E}+02$ \\
\hline $\mathrm{Se}$ & $\mathrm{NR}$ & $\mathrm{NR}$ & $\mathrm{NR}$. & $\mathrm{NR}$ & $\mathrm{NR}$ & $\mathrm{NR}$ \\
\hline $\mathrm{Si}$ as $\mathrm{SiO}_{3}$ & $5.47 \mathrm{E}+02$ & $8.60 \mathrm{E}+02$ & $9.13 \mathrm{E}+02$ & $2.74 \mathrm{E}+03$ & $4.30 \mathrm{E}+03$ & $4.56 \mathrm{E}+03$ \\
\hline $\mathrm{SaS} \mathrm{SO}_{4}$ & $8.51 \mathrm{E}+0 \mathrm{i}$ & $1.05 \mathrm{E}+02$ & $1.08 \mathrm{E}+02$ & $4.25 \mathrm{E}+02$ & $5.23 \mathrm{E}+02$ & $5.40 \mathrm{E}+02$ \\
\hline $\mathrm{S}$ & $\mathrm{NR}$ & $7.65 \mathrm{E}+00$ & $8.93 E+00$ & $\mathrm{NR}$ & $3.83 \mathrm{E}+01$ & $4.47 \mathrm{E}+01$ \\
\hline Sr & $7.26 \mathrm{E}-01$ & $6.98 \mathrm{E}-01$ & $6.94 \mathrm{E}-0 \mathrm{I}$ & $3.63 \mathrm{E}+00$ & $3.49 \mathrm{E}+00$ & $3.47 \mathrm{E}+00$ \\
\hline TOC & $1.81 \mathrm{E}+02$ & $1.74 \mathrm{E}+02$ & $1.73 \mathrm{E}+02$ & $9.06 \mathrm{E}+02$ & $871 \mathrm{E}+02$ & $8.65 \mathrm{E}+02$ \\
\hline Total U & $1.86 \mathrm{E}+02$ & $1.79 \mathrm{E}+02$ & $1.78 \mathrm{E}+02$ & $9.31 \mathrm{E}+02$ & $8.97 \mathrm{E}+02$ & $8.92 \mathrm{E}+02$ \\
\hline & $1.51 \mathrm{E}+00$ & $1.45 \mathrm{E}+00$ & $1.44 \mathrm{E}+00$ & $7.54 \mathrm{E}+00$ & $7.24 \mathrm{E}+00$ & $7.20 \mathrm{E}+00$ \\
\hline
\end{tabular}


HNF-SD-HTI-TI-001, REV. 0

SESC-EN-RPT-002, Rev. 1

Table 13. Tank 241-AX-103 Retrieval Scenario Nouradiological known as) Constituent Leakage Estimate (page 2 of 2)

\begin{tabular}{|l|c|c|c|c|c|c|}
\hline $\begin{array}{l}\text { Release Volume } \\
(\mathrm{L})\end{array}$ & 30,283 & 30,283 & 30,283 & 151,413 & 151,413 & 151,413 \\
\hline Analyte (kg) & Case I & Case II & Case III & Case I & Case II & Case III \\
\hline $\mathrm{Zr}$ & $1.56 \mathrm{E}+01$ & $1.50 \mathrm{E}+01$ & $1.49 \mathrm{E}+01$ & $7.82 \mathrm{E}+01$ & $7.52 \mathrm{E}+01$ & $7.47 \mathrm{E}+01$ \\
\hline $\mathrm{EDTA}$ & $9.77 \mathrm{E}+01$ & $9.39 \mathrm{E}+01$ & $9.32 \mathrm{E}+01$ & $4.88 \mathrm{E}+02$ & $4.69 \mathrm{E}+02$ & $4.66 \mathrm{E}+02$ \\
\hline $\mathrm{NH}_{3}$ & $1.05 \mathrm{E}+01$ & $1.70 \mathrm{E}+01$ & $1.81 \mathrm{E}+01$ & $5.27 \mathrm{E}+01$ & $8.50 \mathrm{E}+01$ & $9.04 \mathrm{E}+01$ \\
\hline $\mathrm{Cr}$ & $\mathrm{NR}$ & $\mathrm{NR}$ & $\mathrm{NR}$ & $\mathrm{NR}$ & $\mathrm{NR}$ & $\mathrm{NR}$ \\
\hline $\mathrm{CN}$ & $\mathrm{NR}$ & $\mathrm{NR}$ & $\mathrm{NR}$ & $\mathrm{NR}$ & $\mathrm{NR}$ & $\mathrm{NR}$ \\
\hline $\mathrm{H}_{2} \mathrm{O}$ & $7.11 \mathrm{E}+03$ & $8.14 \mathrm{E}+03$ & $8.31 \mathrm{E}+03$ & $3.56 \mathrm{E}+04$ & $4.07 \mathrm{E}+04$ & $4.16 \mathrm{E}+04$ \\
\hline Retrieval water & $1.76 \mathrm{E}+04$ & $1.63 \mathrm{E}+04$ & $1.61 \mathrm{E}+04$ & $8.79 \mathrm{E}+04$ & $8.15 \mathrm{E}+04$ & $8.05 \mathrm{E}+04$ \\
\hline Total $(\mathrm{kg})$ & $3.47 \mathrm{E}+04$ & $3.58 \mathrm{E}+04$ & $3.59 \mathrm{E}+04$ & $1.73 \mathrm{E}+05$ & $1.79 \mathrm{E}+05$ & $1.80 \mathrm{E}+05$ \\
\hline
\end{tabular}

bxtose and

(:)

Anas a

in 
(formally known as)

Table 14. Tank 241-AX-103 Retrieval Scenario Radiological Constituent Leakage Estimate (page 1 of 2)

\begin{tabular}{|c|c|c|c|c|c|c|}
\hline Release Volume (I) & 30,283 & 30,283 & 30,283 & 151,413 & 151,413 & 151,413 \\
\hline Analyte (Ci) & Case I & Case. II & Case III & Case I & Case II & Case III \\
\hline Decay Date & $12 / 31 / 99$ & $12 / 31 / 99$ & $12 / 31 / 99$ & $12 / 31 / 99$ & $12 / 31 / 99$ & $12 / 31 / 99$ \\
\hline 等, & $2: 56 \mathrm{E}+00$ & $2.66 \mathrm{E}+00$ & $2.67 \mathrm{E}+00$ & $1.28 \mathrm{E}+01$ & $1.33 \mathrm{E}+01$ & $1.34 \mathrm{E}+01$ \\
\hline${ }^{14} \mathrm{C}$ & $3.53 \mathrm{E}-02$ & $3.39 \mathrm{E}-02$ & $3.37 \mathrm{E}-02$ & $1.76 \mathrm{E}-01$ & $1.70 \mathrm{E}-01$ & $1.68 \mathrm{E}-01$ \\
\hline $59 \mathrm{Ni}$ & $2.06 \mathrm{E}-02$ & $1.96 \mathrm{E}-01$ & $2.26 \mathrm{E}-01$ & 1:03E-01 & $9.82 \mathrm{E}-01$ & $1.13 \mathrm{E}+00$ \\
\hline${ }^{60} \mathrm{Co}$ & $1.44 \mathrm{E}+00$ & $1.19 \mathrm{E}+01$ & $1.36 \mathrm{E}+01$ & $7.19 \mathrm{E}+00$ & $5.94 \mathrm{E}+01$ & $6.82 \mathrm{E}+01$ \\
\hline${ }^{63} \mathrm{Ni}$ & $2.03 \mathrm{E}+00$ & $1.97 \mathrm{E}+01$ & $2.26 \mathrm{E}+01$ & $1.01 \mathrm{E}+01$ & $9.84 \mathrm{E}+01$ & $1.13 \mathrm{E}+02$ \\
\hline${ }^{79} \mathrm{Se}$ & $3.97 \mathrm{E}-02$ & $2.05 \mathrm{E}-01$ & $2.33 \mathrm{E}-0.1$ & $1.99 \mathrm{E}-01$ & $1.03 \mathrm{E}+00$ & $1.16 \mathrm{E}+00$ \\
\hline${ }^{90} \mathrm{Sr}$ & $4.47 E+03$ & $9.54 \mathrm{E}+04$ & $1.11 \mathrm{E}+05$ & $2.24 \mathrm{E}+04$ & $4.77 \mathrm{E}+05$ & $5.53 \mathrm{E}+05$ \\
\hline${ }^{90} \mathrm{Y} \cdots$ & $4.47 \mathrm{E}+03$ & $9.54 E+04$ & $1.11 \mathrm{E}+05$ & $2.24 \mathrm{E}+04$ & 4.77E+05 & $5.53 \mathrm{E}+05$ \\
\hline${ }^{93} \mathrm{mNb}$ & $1.41 \mathrm{E}-01$ & $7.12 \mathrm{E}-01$ & 8.07E-01 & 7:03E-01 & $3.56 \mathrm{E}+00$ & $4.04 E+00$ \\
\hline${ }^{93} \mathrm{Zr} \quad \mathrm{O}$ & $196 \mathrm{E}-01$ & $9.54 \mathrm{E}-01$ & $1: 08 \mathrm{E}+00$ & $9.79 \mathrm{E}-01$ & $4.77 \mathrm{E}+00$ & $5.41 \mathrm{E}+00$ \\
\hline${ }^{99} \mathrm{Te} \mathrm{N}$ & $2.06 \mathrm{E}+00$ & $1.98 \mathrm{E}+00$ & $1.97 \mathrm{E}+00$ & $1.03 E+01$ & $9.91 \mathrm{E}+00$ & $9.84 \mathrm{E}+00$ \\
\hline${ }^{106} \mathrm{Ru}$ & $9.17 \mathrm{E}-05$ & $6.59 \mathrm{E}-04$ & $754 \mathrm{E}-04$ & $4.59 \mathrm{E}-04$ & $3.30 \mathrm{E}-03$ & $3.77 \mathrm{E}-03$ \\
\hline${ }^{113} \mathrm{mCd}$ & $1.07 \mathrm{E}+00$ & $4.31 \mathrm{E}+00$ & $485 \mathrm{E}+00$ & $5.34 \mathrm{E}+00$ & 2.15E+01 & $2.42 \mathrm{E}+01$ \\
\hline${ }^{125} \mathrm{Sb}$ & & $4.18 \mathrm{E}+00$ & $488 \mathrm{E}+00$ & & $2: 09 \mathrm{E}+01$ & $2.44 \mathrm{E}+0 \mathrm{I}$ \\
\hline${ }^{126} \mathrm{Sn}$ & $6.01 \mathrm{E}-02$ & $3.18 \mathrm{E}-01$ & $3.62 \mathrm{E}-01$ & $3.00 \mathrm{E}-01$ & $1.59 E+00$ & $1.81 \mathrm{E}+00$ \\
\hline${ }^{129} \mathrm{I}:$ & $5.51 \mathrm{E}-04$ & 529 E-04 & $5.26 \mathrm{E}-04$ & $2.75 \mathrm{E}-03$ & $2.65 \mathrm{E}-03$ & $2.63 \mathrm{E}-03$ \\
\hline${ }^{134} \mathrm{Cs}$ & $4.18 \mathrm{E}-02$ & $5.19 \mathrm{E}-02$ & $5.36 \mathrm{E}-02$ & $2.09 \mathrm{E}-01$ & $2.59 \mathrm{E}-01$ & $2.68 \mathrm{E}-01$ \\
\hline${ }^{135} \mathrm{Cs}$ & $\mathrm{NR}$ & NR & $\because \mathrm{NR}$ & $\mathrm{NR}$ & NR & NR \\
\hline${ }^{137} \mathrm{Cs}$ & $2.36 \mathrm{E}+03$ & $4.16 \mathrm{E}+03$ & $4.46 \mathrm{E}+03$ & $1.18 \mathrm{E}+04$ & $2.08 \mathrm{E}+04$ & $2.23 \mathrm{E}+04$ \\
\hline $137 \mathrm{mBa}$ & $2.24 \mathrm{E}+03$ & $3.94 \mathrm{E}+03$ & $4.22 \mathrm{E}+03$ & $1.12 \mathrm{E}+04$ & $1.97 \mathrm{E}+04$ & $2.11 \mathrm{E}+04$ \\
\hline${ }^{151} \mathrm{Sm}$ & $1.40 \mathrm{E}+02$ & $7.56 \mathrm{E}+02$ & $8.59 \mathrm{E}+02$ & $6.99 \mathrm{E}+02$ & $3.78 \mathrm{E}+03$ & $4.30 \mathrm{E}+03$ \\
\hline${ }^{152}$ Eu & $5.20 \mathrm{E}-02$ & $240 \mathrm{E}-01$ & $272 \mathrm{E}-01$ & $2.60 \mathrm{E}-01$ & $1,20 \mathrm{E}+00$ & $1.36 \mathrm{E}+00$ \\
\hline${ }^{154} \mathrm{Eu}$ & $\mathrm{NR}$ & $767 \mathrm{E}+01$ & $8.95 \mathrm{E}+01$ & $\mathrm{NR}$ & $3.83 \mathrm{E}+02$ & $4.48 \mathrm{E}+02$ \\
\hline${ }^{155} \mathrm{Eu}$ & $\mathrm{NR}$ & $4.93 \mathrm{E}+01$ & $5.75 \mathrm{E}+01$ & $\mathrm{NR}$ & $2.46 \mathrm{E}+02$ & $2.88 \mathrm{E}+02$ \\
\hline${ }^{226} \mathrm{Ra}$ & $1.53 \mathrm{E}-06$ & $1.26 \mathrm{E}-05$ & $1.44 \mathrm{E}-05$ & $7.66 \mathrm{E}-06$ & $6.28 \mathrm{E}-05$ & $7.20 \mathrm{E}-05$ \\
\hline${ }^{227} \mathrm{Ac}$ & $9.49 \mathrm{E}-06$ & $6.88 \mathrm{E}-05$ & $7.87 \mathrm{E}-05$ & 4.74E-05 & $3.44 \mathrm{E}-04$ & $3.93 \mathrm{E}-04$ \\
\hline${ }^{228} \mathrm{Ra}$ & $4.01 \mathrm{E}-03$ & $3.85 \mathrm{E}-03$ & $3.82 \mathrm{E}-03$ & $2.00 \mathrm{E}-02$ & $1.92 \mathrm{E}-02$ & $1.91 \mathrm{E}-02$ \\
\hline${ }^{229} \mathrm{Th}$ & $9.31 \mathrm{E}-05$ & $8.95 \mathrm{E}-05$ & $8.89 \mathrm{E}-05$ & $4.66 \mathrm{E}-04$ & $4.48 \mathrm{E}-04$ & $4.45 \mathrm{E}-04$ \\
\hline${ }^{231} \mathrm{~Pa}$ & $4.53 \mathrm{E}-05$ & 1:78E-04 & $2.00 \mathrm{E}-04$ & $2.27 \mathrm{E}-04$ & $8.91 \mathrm{E}-04$ & $1.00 \mathrm{E}-03$ \\
\hline${ }^{232} \mathrm{Th}$ & $4.32 \mathrm{E}-04$ & $4.15 \mathrm{E}-04$ & 4.13E-04 & $2.16 \mathrm{E}-03$ & $2.08 \mathrm{E}-03$ & $2.06 \mathrm{E}-03$ \\
\hline${ }^{232} \mathrm{U}$ & $1.20 \mathrm{E}-02$ & $1.15 \mathrm{E}-02$ & $1.14 \mathrm{E}-02$ & $5.99 \mathrm{E}-02$ & $5.76 \mathrm{E}-02$ & $5.72 \mathrm{E}-02$ \\
\hline${ }^{233} \mathrm{U}$ & $4.60 \mathrm{E}-02$ & $4.42 \mathrm{E}=02$ & $4.39 \mathrm{E}-02$ & $2.30 \mathrm{E}-01$ & $221 \mathrm{E}-01$ & $2.20 \mathrm{E}-01$ \\
\hline${ }^{234} \mathrm{U}$ & $7.59 \mathrm{E}-03$ & $7.45 \mathrm{E}-03$ & $7.43 \mathrm{E}-03$ & $3.79 \mathrm{E}-02$ & $372 \mathrm{E}-02$ & $3.71 \mathrm{E}-02$ \\
\hline${ }^{235} \mathrm{U}$ & $3.01 \mathrm{E}-04$ & $2.96 \mathrm{E}-04$ & $295 \mathrm{E}-04$ & $1.51 \mathrm{E}-03$ & $1.48 \mathrm{E}-03$ & $1.48 \mathrm{E}-03$ \\
\hline $236 \mathrm{U}$ & $2.45 \mathrm{E}-04$ & $2.39 \mathrm{E}-04$ & $2.38 \mathrm{E}-04$ & $1.22 \mathrm{E}-03$ & $1.20 \mathrm{E}-03$ & $1.19 \mathrm{E}-03$ \\
\hline
\end{tabular}


Table 14. Tank 241-AX-103 Retrieval Scenario Radiological Constituent Leakage Estimate (page 2 of 2)

\begin{tabular}{|l|c|c|c|c|c|c|}
\hline Release Volume (L) & 30,283 & 30,283 & 30,283 & 151,413 & 151,413 & 151,413 \\
\hline Analyte (Ci) & Case I & Case II & Case III & Case I & Case II & Case III \\
\hline Decay Date & $12 / 31 / 99$ & $12 / 31 / 99$ & $12 / 31 / 99$ & $12 / 31 / 99$ & $12 / 31 / 99$ & $12 / 31 / 99$ \\
\hline${ }^{237} \mathrm{~Np}$ & $1.06 \mathrm{E}-02$ & $1.07 \mathrm{E}-02$ & $1.07 \mathrm{E}-02$ & $5.29 \mathrm{E}-02$ & $5.35 \mathrm{E}-02$ & $5.36 \mathrm{E}-02$ \\
\hline${ }^{238} \mathrm{Pu}$ & $1.58 \mathrm{E}-02$ & $1.57 \mathrm{E}-01$ & $1.80 \mathrm{E}-01$ & $7.92 \mathrm{E}-02$ & $7.83 \mathrm{E}-01$ & $9.01 \mathrm{E}-01$ \\
\hline${ }^{238} \mathrm{U}$ & $1.05 \mathrm{E}-02$ & $1.03 \mathrm{E}-02$ & $1.02 \mathrm{E}-02$ & $5.27 \mathrm{E}-02$ & $5.14 \mathrm{E}-02$ & $5.12 \mathrm{E}-02$ \\
\hline${ }^{239} \mathrm{Pu}$ & $5.20 \mathrm{E}-01$ & $4.15 \mathrm{E}+00$ & $4.75 \mathrm{E}+00$ & $2.60 \mathrm{E}+00$ & $2.07 \mathrm{E}+01$ & $2.38 \mathrm{E}+01$ \\
\hline${ }^{240} \mathrm{Pu}$ & $8.99 \mathrm{E}-02$ & $7.85 \mathrm{E}-01$ & $9.01 \mathrm{E}-01$ & $4.50 \mathrm{E}-01$ & $3.92 \mathrm{E}+00$ & $4.50 \mathrm{E}+00$ \\
\hline${ }^{239 / 240} \mathrm{Pu}$ & $2.02 \mathrm{E}+01$ & $4.27 \mathrm{E}+01$ & $4.65 \mathrm{E}+01$ & $1.01 \mathrm{E}+02$ & $2.14 \mathrm{E}+02$ & $2.32 \mathrm{E}+02$ \\
\hline${ }^{241} \mathrm{Am}$ & $1.24 \mathrm{E}+01$ & $1.19 \mathrm{E}+01$ & $1.18 \mathrm{E}+01$ & $6.19 \mathrm{E}+01$ & $5.95 \mathrm{E}+01$ & $5.91 \mathrm{E}+01$ \\
\hline${ }^{241} \mathrm{Pu}$ & $1.10 \mathrm{E}+00$ & $1.11 \mathrm{E}+01$ & $1.28 \mathrm{E}+01$ & $5.50 \mathrm{E}+00$ & $5.56 \mathrm{E}+01$ & $6.40 \mathrm{E}+01$ \\
\hline${ }^{242} \mathrm{Cm}$ & $1.75 \mathrm{E}-03$ & $6.94 \mathrm{E}-03$ & $7.80 \mathrm{E}-03$ & $8.73 \mathrm{E}-03$ & $3.47 \mathrm{E}-02$ & $3.90 \mathrm{E}-02$ \\
\hline${ }^{242} \mathrm{mAm}$ & NR & NR & NR & NR & NR & NR \\
\hline${ }^{242} \mathrm{Pu}$ & $6.04 \mathrm{E}-06$ & $6.40 \mathrm{E}-05$ & $7.37 \mathrm{E}-05$ & $3.02 \mathrm{E}-05$ & $3.20 \mathrm{E}-04$ & $3.69 \mathrm{E}-04$ \\
\hline${ }^{243} \mathrm{Am}$ & $2.61 \mathrm{E}-05$ & $2.02 \mathrm{E}-04$ & $2.31 \mathrm{E}-04$ & $1.31 \mathrm{E}-04$ & $1.01 \mathrm{E}-03$ & $1.15 \mathrm{E}-03$ \\
\hline${ }^{243} \mathrm{Cm}$ & $1.63 \mathrm{E}-04$ & $5.61 \mathrm{E}-04$ & $6.27 \mathrm{E}-04$ & $8.13 \mathrm{E}-04$ & $2.80 \mathrm{E}-03$ & $3.14 \mathrm{E}-03$ \\
\hline${ }^{244} \mathrm{Cm}$ & $1.41 \mathrm{E}-03$ & $1.38 \mathrm{E}-02$ & $1.58 \mathrm{E}-02$ & $7.04 \mathrm{E}-03$ & $6.88 \mathrm{E}-02$ & $7.92 \mathrm{E}-02$ \\
\hline \multirow{2}{Total}{} & $1.37 \mathrm{E}+04$ & $2.00 \mathrm{E}+05$ & $2.31 \mathrm{E}+05$ & $6.85 \mathrm{E}+04$ & $9.99 \mathrm{E}+05$ & $1.15 \mathrm{E}+06$ \\
\hline
\end{tabular}




\author{
APPENDIX E \\ BEST-BASIS INVENTORY, RETRIEVAL INVENTORY, AND LEAKAGE \\ INVENTORY ESTIMATES \\ FOR RETRIEVAL OF WASTE \\ FROM SINGLE-SHELL TANK 241-AX-104 \\ D. W. Hendrickson, P.E. \\ S. L. Lambert, Ph.D. \\ SGN Eurisys Services Corporation \\ Richland, Washington
}




\section{CONTENTS}

1.0 CHEMICAL INFORMATION SOURCES $\ldots \ldots \ldots \ldots \ldots \ldots \ldots \ldots \ldots \ldots \ldots \ldots \ldots \ldots$

$2.0^{\circ}$ CHEMICAL AND RADIONUCLIDE INVENTORY ESTIMATES $\ldots \ldots \ldots \ldots \ldots$ E-2

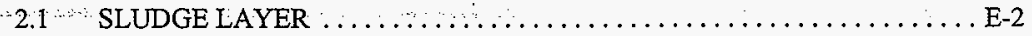

$2.2 \ldots$ BEST-BASIS INVENTORY BEFORE RETRIEVAL $\ldots \ldots \ldots \ldots \ldots \ldots$ E-2

3.0 CHEMICAL/RADIONUCLDDE INVENTORY ESTIMATES AFTER

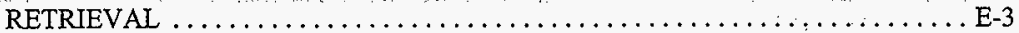

4.0 BEST-BASIS LEAKAGE INVENTORY ESTIMATES FOR RETRIEVAL OF SINGLE-SHELL TANK 241 -AX-104 ...................... E-3

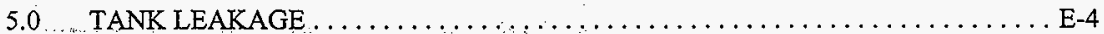

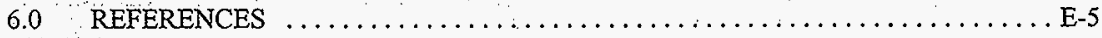

TABLES:

1. Analytical Results and Sludge Inventory Estimates for Nonradioactive Components

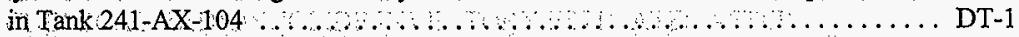

2. Analytical Results and Sludge Inventory Estimates for Nonradioactive Components

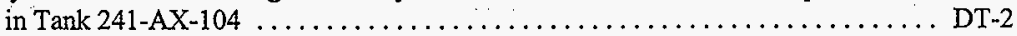

3. Best-Basis Nonradiological Inventory Before Retrieval of Waste From Single-Shell

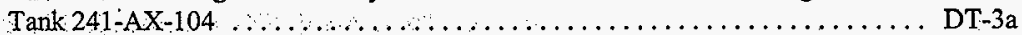

4. Best-Basis Radiological Inventory Before Retrieval of Waste From Single-Shell

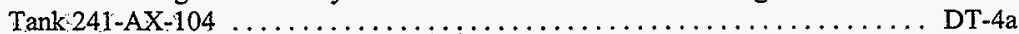

5. Retrieval Scenario Summary of Residual Waste and Fractional Removal .......... DT-5

6. Tank 241-AX-104 Nonradiological Waste Residual Inventory Following Retrieval . . DT-6a

7. Tank 241-AX-104 Radiological Waste Residual Inventory Following Retrieval ..... DT-7a

8. Retrieval Scenario Product Solution Nonradiological Analyte Concentrations ....... DT-8a

9. Retrieval Scenario Product Solution Radiological Analyte Concentrations .......... DT-9a

10. Tank241-AX-104-Retrieval Scenario Nonradiological Constituent Leakage

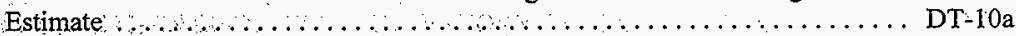

11. Tank 241-AX-104 Retrieval Scenario Radiological Constituent Leakage Estimate . DT-11a

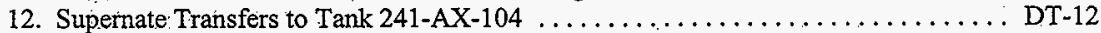

13. Estimated Supernate Composition in Equilibrium with Solids in Tank

$241-\mathrm{AX}-104$ during the Fourth Quarter of $1972 \ldots \ldots \ldots \ldots \ldots \ldots \ldots$ DT-13

14. Composition of Tank 241-A-104 Supernate, Composition of Combined Supernates in Tanik 241-AX-104 and Leakage Source Terms from the Fourth Quarter of 1972 to the Second Quarter of 1974 DT-14

15.) Supernate Composition in Tank 241-AX-104 and Leakage Source Terms from the Third Quarter of 1974 to the First Quarter of $1976 \ldots \ldots \ldots \ldots \ldots \ldots \ldots$ DT 15 
(formally known as)

The purpose of this study is to provide the best-basis estimate of the chemical and radiological waste inventory after retrieval of waste from the 241-AX Tank Farm. As part of this effort, an evaluation of available information for Tank 241-AX-104 was performed and a best-basis inventory was established for three different retrieval scenarios. The first scenario is based on retrieving at least 90 percent of the waste to a residual volume of $101.94 \mathrm{~m}^{3}\left(3,600 \mathrm{ft}^{3}\right)$ of waste, or the current volume if this volume is less than $101.94 \mathrm{~m}^{3}\left(3,600 \mathrm{ft}^{3}\right)$. The second scenario assumes 99 percent retrieval of waste from the tank to meet the Hanford Federal Facility Agreement and Consent Order (Tri-Party Agreement) (Ecology et al. 1990) milestone of $10.19 \mathrm{~m}^{3}\left(360 \mathrm{ft}^{3}\right)$ of residual waste, while the third scenario assumes 99.9 percent retrieval to a residual volume of $1.02 \mathrm{~m}^{3}\left(36 \mathrm{ft}^{3}\right)$ of waste. This study, detailed in the following sections, is based on the methodology that was established by the standard inventory task $\ldots$

\subsection{CHEMICAL INFORMATION SOURCES}

Chemical and radionuclide inventory estimates are generally derived from one of three sources of information: (1) sample analysis and samplè derived inventory estimates, (2) component inventories predicted by the HDW model based on process knowledge and historicaltank transfen information; or (3) a tank-specific process estimate based on process flowsheets, reactor fuel data, essential materials records, or comparable sludge layers and sample information from

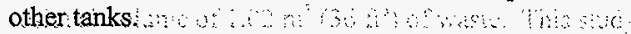

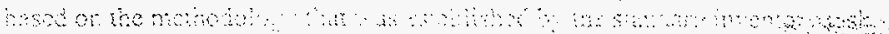

Tank 241-AX-104 was most recently sampled in September 1977 to determine the composition of the residual sludge after the 1977 sluicing campaign. A 10-ml sample of this sludge was delivered to the laboratory and analyzed to determine the chemical and radionuclide composition of the waste: The sample was water washed and digested by potassium hydroxide (KOH) fusion in a zirconium crucible to dissolve the solids. Analyses performed included inductively coupled plasma spectroscopy (ICP) analysis of metals, ion chromatographic (IC) analysis of anions, and mass; spectroscopy for analysis of radionuclides: Other laboratory analyses included percent moisture bulk density and particle density, and size distribution. An aliquot of the wash solution was also analyzed for soluble metals; anions; and radionuclides. This data can be used to compute component inventories by multiplying the concentration of an analyte by the volume and density of the sludge: in the tank. Samples obtained prior to 1977 are of limited yalue because these samples reflect the composition of the waste before the 1977 sluicing campaign.

The waste history of this tank is provided in Anderson (1990). Tank 241-AX-104 was used primarily as:a:PUREX waste receiver from the third quarter of 1966 until the second quarter of 1969 ; followed by the receipt and transfer of various supernates from or to other tanks. The remaining supernate was pumped out for cesium recovery during the third quarter of 1976, while most of the sludge $(196.2 \mathrm{~kL}$ [ $52 \mathrm{kgal}])$ was sluiced for strontium recovery during the second and third quarters of 1977: A second sluicing campaign was conducted during the first quarter of 1978 to remove most of the residual sludge: from this tank (Rodenhizer 1987).. Tank $24 \mathrm{AX}-104$ was declared an assumed leaker in 1977, with an estimated leakage volume of $30.2 \mathrm{~kJ}$ (8. kgal) $\mathrm{A}$ solids volume reevaluation was made in May 1978 and once again in April 1984 ; with interim stabilization being completed in December 1982. 


\subsection{CHEMICAL AND RADIONUCLIDE INVENTORY ESTIMATES}

As of January 1993, the average sludge depth in this tank was determined to be $6.98 \mathrm{~cm}$ (2.75-inch) (Swaney 1993). This depth is slightly higher than the tank farm surveillance estimate $(6.48 \mathrm{~cm}$ ) (Hanlon 1996). Based on this estimate $(6.98 \mathrm{~cm})$, Tank 241-AX-104 contains about $28.7 \mathrm{~kL}$ ( $7.58 \mathrm{kgal})$ of waste (in the $22.86 \mathrm{~m} \mathrm{[} 75 \mathrm{ft}]$ diameter, flat bottom tank). All of this waste apparently consists of sludge. This inventory is about eight percent higher than the tank farm surveillance estimate of $26.5 \mathrm{~kL}$ ( $7 \mathrm{kgal}$ ) (Hanlon 1996). For purposes of this analysis, the current inventory will be based on the tank farm surveillance estimate ( $26.5 \mathrm{~kL}$ of sludge), which is equivalent to 934 cubic feet of residual waste.

\subsection{SLUDGE LAYER}

Table 1 provides a summary of the washed sludge analyses from the 1977 sludge sample and best-basis tank inventory estimates based on the volume and density of the sludge ( $26.5 \mathrm{~kL}$ [7 kgal] and $18 \mathrm{~kg} / \mathrm{L}$; respectively); together with the wash solution components. Wash solution results from the 1977 sample are shown in this table and are referenced to the mass of the washed sludge ( $4.8 \mathrm{ml}$ of solids washed with $15.7 \mathrm{ml}$ of $\mathrm{H}_{2} \mathrm{O}$ ). Because this sample is the only one obtained after the 19.77 sluicing campaign, this sample will be used to estimate the current waste composition in the tank.

Table 2 provides a summary of the mean sludge radionuclide concentrations and tank inventory estimates based on the 1977 grab sample from this tank. Wash solution results are presented as well referenced to the mass of washed sludge. Original analytical values are referenced in Start (1977).

\subsection{BEST-BASIS INVENTORY BEFORE RETRIEVAL}

Based on this analysis; a best-basis inventory was developed. The 1977 grab sample was used to generate estimates for the chemical and radionuclide components in this waste. This waste mostly consists of PUREX high-level waste from Al-clad fuel:

Best-basis radionuclide values were derived for 46 key radionuclides (Kupfer et al. 1997). Often, waste sample analyses have only reported ${ }^{90} \mathrm{Sr},{ }^{137} \mathrm{Cs},{ }^{239 / 240} \mathrm{Pu}$, and total uranium (or total beta and total alpha), while other key radionuclides, such as ${ }^{60} \mathrm{Co},{ }^{99} \mathrm{Tc},{ }^{129} \mathrm{I},{ }^{154} \mathrm{Eu},{ }^{155} \mathrm{Eu}$, and ${ }^{244} \mathrm{Am}$, etc., have been infrequently reported. For this reason it was necessary to derive most of the 46 key radionuclides by computer models. These models estimate radionuclide activity in batches of reactor fuel, account for the split of radionuclides to various separations plant waste streams, and track their movement with tank waste transactions. (Kupfer et al. 1997 and Watrous and Wootan 1997. Model generated values for radionuclides in any of the 177 tanks are reported in the HDW Rev. 4 model results (Agnew et al. 1997a). (No attempt has been made to ratio or normalize model results for all 46 radionuclides when values for measured radionuclides disagree with the model.) (For a discussion of typical error between model-derived values and sample-derived values [Kupfer et al. 1997]). The best-basis inventory for Tank 241-AX-104 is presented in Tables 3 and 4. 


\subsection{CHEMTCAL/RADIONUCLIDE INVENTORY ESTMMATES}

\section{AFTER RETRIEVAL}

As part of this study, a best basis inventory was established for three different retrieval scenarios. The first scenario is based on retrieving waste to minimum of either the existing waste volume or a residual waste volume of $101.94 \mathrm{~m}^{3}\left(3600 \mathrm{ft}^{3}\right)$. The second scenario assumes retrieval to a residual waste volume of $10.2 \mathrm{~m}^{3}\left(360 \mathrm{ft}^{3}\right)$ which corresponds to the assumed 99 percent retrieval of waste to meet the Tri-Party Agreement (Ecology et al. 1990). The third scenario assumes retrieval to a residual waste volume of $1.02 \mathrm{~m}^{3}\left(36 \mathrm{ft}^{3}\right)$. The first and third scenarios represent the retrieval of all tank wastes to 90 percent and 99.9 percent respectively.

Table 5 contains a summary matrix of resultant saltcake and sludge volumes, and their fractional removal, following retrieval according to the three scenarios of 90 percent, 99 percent, and 99.9 percent retrieval.

Following retrieval according to the three scenarios presented in Table 5 , the residual tank waste inventory was evaluated and is presented in Tables 6 and 7 for chemical and radiological constituents, respectively.

\subsection{BEST-BASIS LEAKAGE INVENTORY ESTIMATES FOR RETRIEVAL OF SINGLE-SHELL TANK 241-AX-104}

Retrieval scenarios described in Section 3.0 provide residual inventories following fractional removal of any saltcake and sludges contained within Tank 241-AX-101. This section assumes two different leakage conditions for each retrieval scenario. The first leakage condition assumes up to $30.2 \mathrm{~m}^{3}(8 \mathrm{kgal})$ of potential leakage, while the second leakage condition is based on an upper bounding estimate of $151.4 \mathrm{~m}^{3}(40 \mathrm{kgal})$ of potential leakage. In each case, solution concentrations and inventories will be based on the limiting conditions for waste retrieval, either a maximum supernate concentration of five gram moles per liter sodium or a maximum value of 10 weight percent solids in the slurry, or the total volume of the retrieval solution. These limits were established to minimize the possible crystallization of sodium rich salts in the slurry transfer lines and slurry pumping problems for the slurry pumps and sluicers. The following estimates are based on the methodology that was established by the standard inventory task.

The solution concentrations resulting from dissolution and slurry, with water, of the tank waste according to the three retrieval scenarios are provided in Tables 8 and 9 for nonradiological and radiological constituents, respectively. Table 8 also displays the limiting volume assessment required for application of sodium loading or solids loading limits and the minimum retrieval water required to meet the limiting volume assessment based upon product-specific gravities of either 1.17 or 1.18 for sodium limited or solids limited solutions.

Tables 10 and 11 contain the nonradiological and radiological, resultant leakage inventory estimates based upon $30.2 \mathrm{~m}^{3}$ ( $8 \mathrm{kgal}$ ) and $151.4 \mathrm{~m}^{3}$ ( $40 \mathrm{kgal}$ ) releases during retrieval. 


\subsection{TANK LEAKAGE}

Tank 241-AX-104 was declared an assumed leaker in 1977 with an estimated leakage volume of $30.2 \mathrm{~kL}(8 \mathrm{kgal})$. An occurrence report was filed April 9, 1975 detailing the observed radiation increase in dry well 11-04-11, located about $3.05 \mathrm{~m}$ (10 ft) northwest of Tank 241-AX-104. Apparently, a two-fold increase in radiation count was found at the $12.19 \mathrm{~m}$ (40 ft) level shortly affer the well was drilled in January 1975. Based on auger testing of the soil, the soil around the vapor exhaust header was found to be highly contaminated, with readings as high as $3 \mathrm{RAD}$ at contact. If this is the leakage source of interest, most of the leakage must have been caused by tank condensates that collected in the exhaust header system. Since the composition of this: condensate is not known, we have no basis at the present time for estimating the chemical and radioniclide source terms for condensate leakage. Upper bounding estimates, however, could be developed from the supemate composition data for this tank to evaluate potential leakage effects from this tank.

If leakage occurred at the tank boundary; we should be able to generate reasonable source term estimates from the supernate composition. Based on the dry well response characteristics, it appears that most of the leakage may have occurred during between 1973 and 1974. This tank was initially used as a PUREX waste receiver from the third quarter of 1966 until the second quarter of 1969; followed by the transfer or receipt of various supernates to or from other tanks. Since the only available sample data is from solids rather than liquid samples, other sources of information will be needed to estimate the supernate composition in the tank during the leakage episode: : From the fourth quarter of 1972 to the first quarter of 1976, Tank 241-A:X-104 received several supernate transfers, including $4,845 \mathrm{~kL}(1,280 \mathrm{kgal})$ of $\mathrm{AR}$ vault supernate from Tank $241-\mathrm{A}-104,552 \mathrm{~kL}(146 \mathrm{kgal})$ of dilution water, and $227 \mathrm{~kL}$ ( $60 \mathrm{kgal})$ of AR vault and B. Plantlow-level:(BL) supernates from Tank 241-AX-103: These supenate transactions are summarized in Table 12.

During the fourth quarter of 1972 , the volume of waste in Tank 241 -AX-104 was reduced to as little as $416 \mathrm{~kL}$ (110 kgal), including $178 \mathrm{~kL}$ (47 kgal) of sludge and $238 \mathrm{~kL}$ ( $63 \mathrm{kgal}$ ) of supernate (Agnew et al., 1996). Large volumes ( $393 \mathrm{kgal}$ ) of water were added to this tank in 1970 and most of the supernate $(1,270 \mathrm{kgal})$ was removed during the fourth quarter of 1972 . The remaining supernate (63. $\mathrm{kgal}$ ) is assumed to be in equilibrium with the dominant wastes in this tank: According to the HDW model, the dominant waste consisted of PUREX high-level (P2) waste that composed about 94 percent of the total sludge volume in this tank. The supernate composition in equilibrium with this waste can be estimated from the 1977 sludge washing results based on the PUREX wastes that were left in this tank after the 1977 sluicing campaign. These results are summarized in Table 9.

From the fourth quarter of 1972 to the second quarter of 1974 , it appears that 93 percent of the supernate in this tank was directly or indirectly derived from AR vault supemates transferred from:Tank 241-A-104. The composition of this supernate was measured in 1974, the results of which are summarized in Table 10. Also included is the estimated composition of the combined supernate from the fourth quarter of 1972 to the second quarter of 1974, together with the estimated chemical and radiological source terms for any leakage that may have occurred during this period $\therefore$. 
(formally known as)

From the third quarter of 1974 to the first quarter of 1976 , the supernate sources included $1,688 \mathrm{~kL}$ (446 kgal) of $A R$ vault supernate from Tank $241-A-104,227 \mathrm{~kL}$ ( $60 \mathrm{kgal}$ ) of $A R$ vault and B Plant low-level (BL) supernate from Tank 241-AX-103, $204 \mathrm{~kL}$ (54 kgal) of residual supernate from the $1972-74$ period, and $552 \mathrm{~kL}(146 \mathrm{kgal})$ of dilution water. Thus, about 74 percent of the supernate was directly of indirectly derived from $A R$ vault supernates transferred from Tanks 241-A-104 and 241-AX-103. Table 11 provides a summary of the estimated supernate composition in Tank 241-AX-104 and leakage source terms from the third quarter of 1974 to the first quarter of 1976.

\subsection{REFERENCES}

Agnew, S. F, J. Boyer, R. Corbin, T. Duran, J. FitzPatrick, K. Jurgensen, T. Ortiz, and B. Young, 1997a, Hanford Tank Chemical and Radionuclide Inventories: HDW Model Rev. a.: 4, LA-UR-96-3860, Los Alamos National Laboratory, Los Alamos, New Mexico.

Agnew, S. F., R., A Corbin; T B. Duran, K: A: Jurgensen, T. P. Ortiz, and B. L: Young, 1997b, W:: Waste. Status and Trânsaction Records Summary (WSTRS Rev. 4), LA-UR-97-311, Rev. and Los Alamos National Laboratory, Los: Alamos, New Mexico.

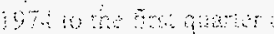

Agnew, S. F. and J. G. Watkin, 1994, Estimate of Limiting Solubilities for Ionic Species in Hanford Waste Tank Supernates, LAUR-94-3590, Los Alamos Laboratory, Los Alamos, New Mexico.

Anderson, J. D., 1990, A History of the 200 Area Farms, WHC-MR-0132, Westinghouse A.m $*$ Hanford Company, Richland, Washington.

Ecology, EPA, and DOE, 1990, Hanford Federal Facility Agreement and Consent Order, 2 vols., as amended; Washington State Department of Ecology, U.S. Environmental W... Protection Agency, U.S. Department of Energy, Olympia; Washington.

Hanlon,B,M,; 1996,Waste Tank Summary Report.for Month Ending May 31, 1996, WHC-EP-182-99, Westinghouse Hanford Company, Richland, Washington.

Kupfer, M. J, A.L. Boldt;:B. A. Higley, K. M: Hodgson, L. W. Shelton, and R. A. Watrous a.: (LMHC); S. L. Lambert, and D. E. Place (SESC), R. M. Orme (NHC), G. L. Borsheim (Borsheim Associates), N. G. Colton (PNNL), M. D. LeClair (SAIC), and R. T. Winward (Meier Associates); and W. W. Schulz (W'S Corporation); 1997, Standard Inventories of Chemicals and Radionuclides in Hanford Site Tank Wastes, HNF-SD-WM-TI-740, Rev. 0, (to be issued), Lockheed Martin Hanford Corporation, Richland, Washington.

Larson, D E:, 19,67, B-Plant Phase III Flowsheets, ISO-986, Isochem, Inc., Richland, Washington.

Rodenhizer, D. G, 1987, Hanford Waste-Tank Sluicing History, WHC-SD-WM-TI-302, Westinghouse Hanford Company; Richland, Washington. .... 
Starr, J. L., 1977, 104-AX Sludge Analysis, WHC-SD-WM-ER-309, Rev.0, Rockwell Hanford Operations, Richland, Washington.

Swaney, S. L., 1993, Waste Level Discrepancies Between Manual Level Readings and Current Waste Inventory for Single-Shell Tanks, (internal memo 7C242-93-038 to G. T. Frater, December 10), Westinghouse Hanford Company, Richland, Washington.

Van Tuyl, H. H., 1958, Composition of Some PUREX Plant IWW Solutions, HW-57280, General Electric Co,; Richland, Washington.

Watrous, R. A., and D. W. Wootan, 1997, Activity of Fuel Batches Processed Through Hanford Separations Plants, 1944 Through 1989, HNF-SD-WM-TI-794, Rev. 0, Lockheed Martin Hanford Corporation, Richland, Washington.

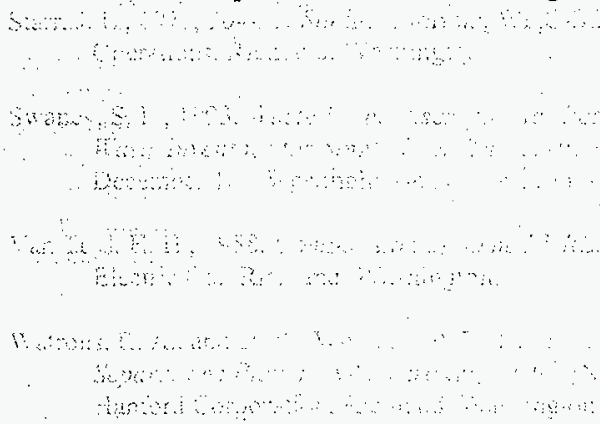


Table 1. Analytical Results and Sludge Inventory Estimates for Nonradioactive Components in Tank 241-AX-104

\begin{tabular}{|c|c|c|c|}
\hline Component & $\begin{array}{l}1977 \text { Sludge } \\
\text { Concentration }(\mathrm{M})^{\mathrm{a}}\end{array}$ & $\begin{array}{l}1977 \text { Wash Solution } \\
\text { Concentration }(\mathrm{M})^{\mathrm{b}}\end{array}$ & $\begin{array}{c}\text { Total Tank } \\
\text { Inventory }(\mathrm{kg})\end{array}$ \\
\hline \multicolumn{4}{|c|}{ Density $\quad 180 \mathrm{~g} / \mathrm{mL}$} \\
\hline $\mathrm{Al}$ & 2.465 & 0.013 & 1,778 \\
\hline $\mathrm{Ba}$ & 0.021 & $\mathrm{NR}$ & 76.7 \\
\hline $\mathrm{Ca}$ & 0.642 & NR & 684 \\
\hline $\mathrm{Cd}$ & 0.015 & NR & 8448 \\
\hline $\mathrm{Cr}$ & 0.061 & NR & 84.4 \\
\hline $\mathrm{Fe}$ & 5.31 & $\mathrm{NR}$ & 7,887 \\
\hline $\mathrm{Mg}$ & 0.171 & $\mathrm{NR}$ & 111 \\
\hline $\mathrm{Mn}$ & 0.0845 & NR & 123 \\
\hline $\mathrm{Na}$ & 2.99 & 0.337 & 2,034 \\
\hline No & $0: 26: y^{3}$ & $\mathrm{NR}$ & 406 \\
\hline $\mathrm{NO}_{2} \mathrm{Ou}$ & $\mathrm{NR}$ & 0.083 & 102 \\
\hline $\mathrm{NO}_{3}$ & 114 & 0.09 & $<2,028$ \\
\hline$\Theta \mathrm{H}$ & $\mathrm{NR}$ & 15.6 & 7,056 \\
\hline $\mathrm{P}$ as $\mathrm{PO}_{4}$ & 0.11 & NR & 278 \\
\hline $\mathrm{P}$ & 0.11 & NR & 90.6 \\
\hline $\mathrm{Si}$ as $\mathrm{SiO}_{3}$ & 2.485 & $\mathrm{NR}$ & $5 ; 028$ \\
\hline $\mathrm{S}$ as $\mathrm{SO}_{4}$ & 0.125 & 0.01 & 345 \\
\hline$S$ & 0.125 & 0.01 & 115 \\
\hline Un. & $1.79 \mathrm{E}-05$ & NR & 0.11 \\
\hline $\mathrm{H}_{2} \mathrm{O}$ & 40.97 & $\mathrm{NR}$ & 19,628 \\
\hline $\mathrm{Pi}$ & 0.213 & $\mathrm{NR}$ & $1,354:$ \\
\hline Yolume (kL) & 26.6 & & \\
\hline \multicolumn{4}{|c|}{$\begin{array}{l}\text { Average of two KOH fusion determinations from September } 1977 \mathrm{grab} \\
\text { sample (Starr 1977) }\end{array}$} \\
\hline \multicolumn{4}{|c|}{$\begin{array}{l}\text { Wash solution composition based on mass of washed sludge } \\
\text { (1.8 } / \mathrm{mL} \text { ). } \\
\text { Tank inventory based on } 26.6 \mathrm{~kJ} \text { of sludge with an average density of } \\
180 \mathrm{~kg} / \mathrm{L}\end{array}$} \\
\hline
\end{tabular}


Table 2. Analytical Results and Sludge Inventory Estimates for Nonradioactive Components in Tank 241-AX-104

\begin{tabular}{|c|c|c|c|}
\hline Component & $\begin{array}{c}1977 \text { Sludge } \\
\text { Concentration }(\mathrm{Ci} / \mathrm{L})^{\mathrm{a}}\end{array}$ & $\begin{array}{l}1977 \text { Wash Solution } \\
\text { Concentration }(\mathrm{Ci} / \mathrm{L})^{\mathrm{b}}\end{array}$ & Total Tank Inventory $(\mathrm{Ci})^{\circ}$ \\
\hline Decay & $12 / 31 / 99$ & $12 / 31 / 99$ & $12 / 31 / 99$ \\
\hline${ }^{60} \mathrm{Co}$ & 0.0059 & NR & 157 \\
\hline${ }^{90} \mathrm{Sr}$ & 51.5 & 0.0133 & $1.36 \mathrm{E}+06$ \\
\hline${ }^{90} \mathrm{Y}$ & 51.5 & 0.0133 & $1.36 \mathrm{E}+06$ \\
\hline${ }^{125} \mathrm{Sb}$ & 0.0024 & NR & $6 \quad 5 \quad 206$ \\
\hline${ }^{137} \mathrm{Cs}$ & 1.063 & 0.0086 & 28,266 \\
\hline${ }^{137} \mathrm{mBa}$ & 1.006 & 0.0081 & 26,611 \\
\hline${ }^{154} \mathrm{Eu}$ & 0.0434 & $\mathrm{NR}$ & 1148 \\
\hline${ }^{155} \mathrm{Eu}$ & 0.0279 & NR & 738 \\
\hline $23 / 2420 \mathrm{Pu}$ & 0.0132 & NR & 349 \\
\hline \multicolumn{4}{|c|}{ Average of two $\mathrm{KOH}$ fúsion determinations from September 1977 grab sample } \\
\hline \multicolumn{4}{|c|}{$\begin{array}{l}\text { (Starr 1977). } \\
\text { Wash solution composition based on mass of washed sludge }(1.8 \mathrm{~g} / \mathrm{mL}) \text {. } \\
\text { Tank inventory based on } 26.6 \mathrm{~kL} \text { of sludge with an average density of } 1 \text {. }\end{array}$} \\
\hline
\end{tabular}


HNF-SD-HTI-TI-001, REV. 0

SESC-EN-RPT-002, Rev. 1

(formally known as)

Table 3. Best-Basis Nonradiological Inventory Before Retrieval of Waste

From Single-Shell Tank 241-AX-104 (page 1 of 2)

\begin{tabular}{|c|c|c|c|}
\hline & Sludge & Saltcake & Overall \\
\hline Density $\left(\mathrm{kg} / \mathrm{m}^{3}\right)$ & $1,800.0$ & 0.0 & $1,800.0$ \\
\hline Volume $\left(\mathrm{m}^{3}\right)$ & 26.5 & 0.0 & 26.5 \\
\hline Components (M) & & & Inventory $(\mathrm{kg})$ \\
\hline $\mathrm{Ag}$ & $\mathrm{NR}$ & $\mathrm{NA}$ & NR \\
\hline $\mathrm{Al}$ & $2.49 E+00$ & $\mathrm{NA}$ & $1,780.0$ \\
\hline As & $\mathrm{NR}$ & $\mathrm{NA}$ & NR \\
\hline B. & $\mathrm{NR}$ & NA & NR \\
\hline $3 a$ & $2.10 \mathrm{E}-02$ & $\mathrm{NA}$ & 76.3 \\
\hline$B i$ & $\mathrm{NR}$ & $\mathrm{NA}$ & $\mathrm{NR}$ \\
\hline $\mathrm{Ca}$ & $6.45 \mathrm{E}-01$ & $\mathrm{NA}$ & 684.0 \\
\hline $\mathrm{Cd}$ & $1.50 \mathrm{E}-02$ & $\mathrm{NA}$ & 44.6 \\
\hline $\mathrm{Cl}$ & $1.16 \mathrm{E}-01$ & $\mathrm{NA}$ & 109.0 \\
\hline $\mathrm{IC}$ as $\mathrm{CO}_{3}$ & $2.43 \mathrm{E}-01$ & $\mathrm{NA}$ & 386.0 \\
\hline $\mathrm{Cr}$ & $6.10 \mathrm{E}-02$ & $\mathrm{NA}$ & 83.9 \\
\hline $\mathrm{Eu}$ & $\mathrm{NR}$ & $\mathrm{NA}$ & NR \\
\hline F & NR & $\mathrm{NA}$ & $\mathrm{NR}$ \\
\hline $\mathrm{Ee}$ & $5.34 \mathrm{E}+00$ & $\mathrm{NA}$ & $7,890.0$ \\
\hline $\mathrm{Fg}$ & NR & $\mathrm{NA}$ & NR \\
\hline $\mathrm{K}$ & $3.40 \mathrm{E}+00$ & $\mathrm{NA}$ & $3,516.0$ \\
\hline $\mathrm{La}$ & NR & $\mathrm{NA}$ & NR \\
\hline $\mathrm{Mg}$ & $1.71 \mathrm{E}-01$ & NA & 110.0 \\
\hline $\mathrm{Mn}$ & $8.45 \mathrm{E}-02$ & $\mathrm{NA}$ & 122.8 \\
\hline $\mathrm{Na}$ & $4.03 \mathrm{E}+00$ & $\mathrm{NA}$ & $2,450.0$ \\
\hline $\mathrm{Ni}$ & $2.60 \mathrm{E}-01$ & $\mathrm{NA}$ & 403.8 \\
\hline $\mathrm{NO}_{2}$ & $8.38 \mathrm{E}-02$ & $\mathrm{NA}$ & 102.0 \\
\hline $\mathrm{NO}_{3}$ & $1.24 \mathrm{E}+00$ & $\mathrm{NA}$ & $2,030.0$ \\
\hline $\mathrm{OH}$ & $2.58 \mathrm{E}+0 \mathrm{1}^{2}$ & $\mathrm{NA}$ & $11,600.0$ \\
\hline $\mathrm{Bb}$ & $1.99 \mathrm{E}-02$ & $\mathrm{NA}$ & 109.0 \\
\hline $\mathrm{as} \mathrm{PO}_{4}$ & $1.11 \mathrm{E}-01$ & $\mathrm{NA}$ & 278.0 \\
\hline 8 & $110 \mathrm{E}-01$ & $\mathrm{NA}$ & $90.2^{-4}$ \\
\hline $\mathrm{Se}$ & NR & $\mathrm{NA}$ & $\mathrm{NR}$ \\
\hline $\mathrm{Si}$ as $\mathrm{SiO}_{3}$ & $2.50 \mathrm{E}+00$ & $\mathrm{NA}$ & $5,038.7$ \\
\hline $\mathrm{sas} \mathrm{SO}_{4}$ & $1.35 \mathrm{E}-01$ & $\mathrm{NA}$ & 343.1 \\
\hline 5 & $1.35 \mathrm{E}-01$ & $\mathrm{NA}$ & 114.5 \\
\hline $\mathrm{sr}$ & $1.25 \mathrm{E}-02$ & $\mathrm{NA}$ & 29.0 \\
\hline $\mathrm{SOC}$ & $\mathrm{NR}$ & $\mathrm{NA}$ & NR \\
\hline Total U & $1.79 \mathrm{E}-05$ & $\mathrm{NA}$ & 0.11 \\
\hline
\end{tabular}


HNF-SD-HTI-TI-001, REV. O

Table 3. Best-Basis Nonradiological Inventory Before Retrieval of Waste

From Single-Shell Tank 241-AX-104 (page 2 of 2)

\begin{tabular}{|l|r|r|r|}
\hline & \multicolumn{1}{|c|}{ Sludge } & Saltcake & \multicolumn{1}{c|}{ Overall } \\
\hline Density $\left(\mathrm{kg} / \mathrm{m}^{3}\right)$ & $1,800.0$ & 0.0 & $1,800.0$ \\
\hline Volume $\left(\mathrm{m}^{3}\right)$ & 26.5 & 0.0 & 26.5 \\
\hline Components $(\mathrm{M})$ & & & Inventory $(\mathrm{kg})$ \\
\hline $\mathrm{Zn}$ & $\mathrm{NR}$ & $\mathrm{NA}$ & $\mathrm{NR}$ \\
\hline $\mathrm{Zr}$ & $\mathrm{NR}$ & $\mathrm{NA}$ & $\mathrm{NR}$ \\
\hline $\mathrm{EDTA}$ & $\mathrm{NR}$ & $\mathrm{NA}$ & $\mathrm{NR}$ \\
\hline $\mathrm{NH}_{3}$ & $\mathrm{NR}$ & $\mathrm{NA}$ & $\mathrm{NR}$ \\
\hline $\mathrm{Cr}^{+6}$ & $\mathrm{NR}$ & $\mathrm{NA}$ & $\mathrm{NR}$ \\
\hline $\mathrm{CN}$ & $\mathrm{NR}$ & $\mathrm{NA}$ & $\mathrm{NR}$ \\
\hline $\mathrm{H}_{2} \mathrm{O}$ & $4.10 \mathrm{E}+01$ & $\mathrm{NA}$ & $19,527.1$ \\
\hline $\mathrm{Pu}$ & $2.13 \mathrm{E}-01$ & $\mathrm{NA}$ & $1,347.0$ \\
\hline
\end{tabular}


HNF-SD-HTI-TI-001, REV. , 0 .

SESC-EN-RPT-002, Rev. 1

(formally known as)

Table 4. Best-Basis Radiological Inventory Before Retrieval of Waste From Single-Shell Tank 241-AX-104 (page 1 of 2)

\begin{tabular}{|c|c|c|c|}
\hline $\begin{array}{l}\text { Components } \\
(\mathrm{Ci} / \mathrm{L})\end{array}$ & Sludge & Saltcake & Overall (Ci) \\
\hline Decay & $12 / 31 / 99$ & $12 / 31 / 99$ & $12 / 31 / 99$ \\
\hline 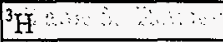 & $1.28 \mathrm{E}-04$ & $\mathrm{NA}$ & $3.38 \mathrm{E}+00$ \\
\hline${ }^{14} \mathrm{C}$ & $2.38 \mathrm{E}-05$ & NA & $6.30 \mathrm{E}-01$ \\
\hline${ }^{59} \mathrm{Ni}$ & $1.18 \mathrm{E}-04$ & NA & $3: 12 \mathrm{E}+00$ \\
\hline${ }^{60} \mathrm{Co}$ & $5.94 \mathrm{E}-03$ & $\mathrm{NA}$ & $1.57 \mathrm{E}+02$ \\
\hline${ }^{63} \mathrm{Ni}$ & $1.18 \mathrm{E}-02$ & $\mathrm{NA}$ & $3.13 E+02$ \\
\hline${ }^{79} \mathrm{Se}$ & $1.11 \mathrm{E}-04$ & $\mathrm{NA}$ & $2.95 E+00$ \\
\hline${ }^{90} \mathrm{Sr}$ & $5.15 \mathrm{E}+01$ & $\mathrm{NA}$ & $1.36 \mathrm{E}+06$ \\
\hline${ }^{90} Y$ & $5.15 E+01$ & $\mathrm{NA}$ & $1.36 \mathrm{E}+06$ \\
\hline $3 \mathrm{mNb}$ & $3.85 \mathrm{E}-04$ & $\mathrm{NA}$ & $1.02 \mathrm{E}+01$ \\
\hline${ }^{93} \mathrm{Zr}$ & $5.14 \mathrm{E}-04$ & NA & $1.36 \mathrm{E}+01$ \\
\hline${ }^{99} \mathrm{Tc}$ & $1.69 \mathrm{E}-04$ & $\mathrm{NA}$ & $4.47 \mathrm{E}+00$ \\
\hline${ }^{106} \mathrm{Ru}$ & $3.82 \mathrm{E}-07$ & NA & $1.01 \mathrm{E}-02$ \\
\hline${ }^{113} \mathrm{mCd}$ & $2.20 \mathrm{E}-03$ & $\mathrm{NA}$ & $5: 82 \mathrm{E}+01$ \\
\hline${ }^{125} \mathrm{Sb}$ & $2.37 \mathrm{E}-03$ & NA & $6.26 \mathrm{E}+01$ \\
\hline${ }^{126} \mathrm{Sn}$ & $1.74 \mathrm{E}-04$ & $\mathrm{NA}$ & $4.61 \mathrm{E}+00$ \\
\hline${ }^{129} \mathrm{I}$ & $3.27 \mathrm{E}-07$ & $\mathrm{NA}$ & $8.64 \mathrm{E}-03$ \\
\hline${ }^{134} \mathrm{Cs}$ & $7.82 \mathrm{E}-06$ & $\mathrm{NA}$ & $2.07 \mathrm{E}=01$ \\
\hline${ }^{135} \mathrm{Cs}$ & $\mathrm{NR}$ & $\mathrm{NA}$ & NR: \\
\hline${ }^{137} \mathrm{Cs}$ & $1.07 \mathrm{E}+00$ & $\mathrm{NA}$ & $2.83 \mathrm{E}+04$ \\
\hline${ }^{137} \mathrm{mBa}$ & $1.01 \mathrm{E}+00$ & $\mathrm{NA}$ & $2.66 \mathrm{E}+04$ \\
\hline${ }^{15} \mathrm{Sm}$ & $4.16 \mathrm{E}-01$ & $\mathrm{NA}$ & $1.10 \mathrm{E}+04$ \\
\hline${ }^{152} \mathrm{Eu}$ & $1.27 \mathrm{E}-04$ & $\mathrm{NA}$ & $3.36 \mathrm{E}+00$ \\
\hline${ }^{154} \mathrm{Eu}$ & $4.34 \mathrm{E}-02$ & $\mathrm{NA}$ & $1.15 \mathrm{E}+03$ \\
\hline${ }^{155} \mathrm{Eu}$ & $2.79 \mathrm{E}-02$ & $\mathrm{NA}$ & $7.38 \mathrm{E}+02$ \\
\hline${ }^{226} \mathrm{Ra}$ & $7.41 \mathrm{E}-09$ & $\mathrm{NA}$ & $1.96 \mathrm{E}-04$ \\
\hline${ }^{227} \mathrm{Ac}$ & $4.01 \mathrm{E}-08$ & $\mathrm{NA}$ & $1.06 \mathrm{E}-03$ \\
\hline${ }^{228} \mathrm{Ra}$ & $6.69 \mathrm{E}-14$ & NA & $1.77 \mathrm{E}-09$ \\
\hline${ }^{229} \mathrm{Th}$ & $1.05 \mathrm{E}-11$ & $\mathrm{NA}$ & $2.77 \mathrm{E}-07$ \\
\hline${ }^{231} \mathrm{~Pa}$ & 8.99E-08 & $\mathrm{NA}$ & $2.38 \mathrm{E}-03$ \\
\hline${ }^{232} \mathrm{Th}$ & $6.05 \mathrm{E}-15$ & $\mathrm{NA}$ & $1.60 \mathrm{E}-10$ \\
\hline${ }^{232} \mathrm{U}$ & $8.39 \mathrm{E}-12$ & $\mathrm{NA}$ & 2.22E-07 \\
\hline${ }^{233} \mathrm{U}$ & $1.98 \mathrm{E}-13$ & $\mathrm{NA}$ & $5.24 \mathrm{E}-09$ \\
\hline${ }^{234} \mathrm{U}$ & $1.04 \mathrm{E}-07$ & $\mathrm{NA}$ & $2.74 \mathrm{E}-03$ \\
\hline${ }^{235} \mathrm{U}$ & $4.31 \mathrm{E}-09$ & $N A$ & $1.14 \mathrm{E}-04$ \\
\hline
\end{tabular}


Table 4. Best-Basis Radiological Inventory Before Retrieval forma known as) of Waste From Single-Shell Tank 241-AX-104 (page 2 of 2)

\begin{tabular}{|c|c|c|c|}
\hline $\begin{array}{l}\text { Components } \\
(\mathrm{Ci} / \mathrm{L})\end{array}$ & Sludge & Saltcake & Overall (Ci) \\
\hline Decay & $12 / 31 / 99$ & $12 / 31 / 99$ & $12 / 31 / 99$ \\
\hline${ }^{236} \mathrm{U}$ & $2.82 \mathrm{E}-09$ & NA & $7.47 \mathrm{E}-05$ \\
\hline${ }^{237} \mathrm{~Np}$ & 3.61.E-07 & NA & $9.54 \mathrm{E}-03$ \\
\hline${ }^{238} \mathrm{Pu}$ & $9.45 \mathrm{E}-05$ & NA & $2.50 \mathrm{E}+00$ \\
\hline${ }^{238} \mathrm{U}$ & $1.01 \mathrm{E}-07$ & $\mathrm{NA}$ & $2.67 \mathrm{E}-03$ \\
\hline${ }^{239} \mathrm{Pu}$ & $2.45 \mathrm{E}-03$ & NA & $6.47 \mathrm{E}+01$ \\
\hline${ }^{240} \mathrm{Pu}$ & $4.65 \mathrm{E}-04$ & NA & $1.23 \mathrm{E}+0.1$ \\
\hline${ }^{239 / 240} \mathrm{Pu}$ & 1.32E-02 & NA & $3.49 \mathrm{E}+02$ \\
\hline${ }^{241} \mathrm{Am}$ & $3.85 \mathrm{E}-03$ & NA & $1.02 \mathrm{E}+02$ \\
\hline${ }^{241} \mathrm{Pu}$ & $6.73 \mathrm{E}-03$ & $\mathrm{NA}$ & $1.78 \mathrm{E}+02$ \\
\hline${ }^{242} \mathrm{Cm}$ & $3.51 \mathrm{E}=06$ & $\mathrm{NA}$ & $9.29 \mathrm{E}-02$ \\
\hline${ }^{242} \mathrm{mAm}$ & NR & $\mathrm{NA}$ & NR \\
\hline${ }^{242} \mathrm{Pu}$ & $3.89 \mathrm{E}-08$ & NA & $1.03 \mathrm{E}-03$ \\
\hline${ }^{243} \mathrm{Am}$ & $1.18 \mathrm{E}-07$ & $\mathrm{NA}$ & 3.12E-03 \\
\hline${ }^{243} \mathrm{Cm}$ & $2.70 \mathrm{E}-07$ & $\mathrm{NA}$ & $7.14 \mathrm{E}-03$ \\
\hline${ }^{244} \mathrm{Cm}$ & $8.28 \mathrm{E}-06$ & $\mathrm{NA}$ & $2.19 \mathrm{E}-01$ \\
\hline Total & & & $2.79 \mathrm{E}+0$ \\
\hline
\end{tabular}


HNF-SD-HTI-TI-001, REV: 0

SESC-EN-RPT-002, Rev. 1

(formally known as)

Table 5. Retrieval Scenario Summary of Residual Waste and Fractional Removal

\begin{tabular}{|l|r|r|r|}
\hline & \multicolumn{1}{|c|}{ Case I } & \multicolumn{1}{c|}{ Case II } & \multicolumn{1}{l|}{ Case III } \\
\hline Vol Base $\left(\mathrm{m}^{3}\right)$ & 101.94 & 10.19 & 1.02 \\
\hline$\%$ Base & $90.0 \%$ & $99.0 \%$ & $99.9 \%$ \\
\hline Target $\left(\mathrm{m}^{3}\right)$ & 26.46 & 10.19 & 1.02 \\
\hline Sludge $\left(\mathrm{m}^{3}\right)$ & 26.46 & 10.19 & 1.02 \\
\hline Saltcake $\left(\mathrm{m}^{3}\right)$ & 0.00 & 0.00 & 0.00 \\
\hline Sludge Removal & $0.0 \%$ & $61.5 \%$ & $96.1 \%$ \\
\hline Saltcake Removal & NA & NA & NA \\
\hline
\end{tabular}

NA = Not Applicable. No saltcake identified in tank. 
HNF-SD-HTI-TI-001, REV. 0

SESC-EN-RPT-002, Rev. 1

(formally known as)

Table 6. Tank 241-AX-104 Nonradiological Waste Residual Inventory Following Retrieval (page 1 of 2)

\begin{tabular}{|c|c|c|c|}
\hline Residual Waste (kg) & Case I & Case II & Case III \\
\hline Target $\left(\mathrm{m}^{3}\right)$ & 26.46 & 10.19 & 1.02 \\
\hline Sludge $\left(\mathrm{m}^{3}\right)$ & 26.46 & 10.19 & 1.02 \\
\hline Saltcake $\left(\mathrm{m}^{3}\right)$ & 0.00 & 0.00 & 0.00 \\
\hline $\mathrm{Ag}$ & NR & NR & NR \\
\hline $\mathrm{Al}$ & $1.78 \mathrm{E}+03$ & $6.86 \mathrm{E}+02$ & $6.86 \mathrm{E}+01$ \\
\hline As & $\mathrm{NR}$ & NR & $\mathrm{NR}$ \\
\hline $\mathrm{B}$ & $\mathrm{NR}$ & NR & NR \\
\hline $\mathrm{Ba}$ & $7.63 \mathrm{E}+01$ & $2.94 \mathrm{E}+01$ & $2.94 \mathrm{E}+00$ \\
\hline $\mathrm{Bi}$ & $\mathrm{NR}$ & $\mathrm{NR}$ & $\mathrm{NR}$ \\
\hline $\mathrm{Ca}$ & $6.84 \mathrm{E}+02$ & $2.64 \mathrm{E}+02$ & $2.64 \mathrm{E}+01$ \\
\hline $\mathrm{Cd}$ & $4.46 \mathrm{E}+01$ & $1.72 \mathrm{E} \div 01$ & $1.72 \mathrm{E}+00$ \\
\hline $\mathrm{Cl} \cdots$ & $1.09 \mathrm{E}+02$ & $4.20 \mathrm{E}+0.1$ & $4.20 \mathrm{E}+00$ \\
\hline $\mathrm{TIC}$ as $\mathrm{CO}_{3}$ & $3.86 \mathrm{E}+02$ & $1.49 \mathrm{E}+02$ & $1.49 \mathrm{E}+01$ \\
\hline $\mathrm{Cr}$ & $8.39 \mathrm{E}+01$ & $3.23 \mathrm{E}+01$ & $3.23 \mathrm{E}+00$ \\
\hline $\mathrm{Cu}$ & $\mathrm{NR}$ & NR & $\mathrm{NR}$ \\
\hline$F:$ & $\mathrm{NR}$ & $\mathrm{NR}$ & NR \\
\hline $\mathrm{Fe}$ & $7.89 \mathrm{E}+03$ & $3.04 \mathrm{E}+03$ & $3.04 \mathrm{E}+02$ \\
\hline $\mathrm{Hg}$ & $\mathrm{NR}$ & $\mathrm{NR}$ & $\mathrm{NR}$ \\
\hline K. & $3.52 \mathrm{E}+03$ & $1.35 \mathrm{E}+03$ & $1.35 \mathrm{E}+02$ \\
\hline $\mathrm{La}$ & NR. & $\mathrm{NR}$ & $\mathrm{NR}$ \\
\hline $\mathrm{Mg}$ & $1.10 \mathrm{E}+02$ & $4.24 \mathrm{E}+01$ & $4.24 \mathrm{E}+00$ \\
\hline $\mathrm{Mn}$ & $1.23 \mathrm{E}+02$ & $473 E+01$ & $4.73 \mathrm{E}+00$ \\
\hline $\mathrm{Na}$ & $2.45 \mathrm{E}+03$ & $9.44 \mathrm{E}+02$ & $9.44 \mathrm{E}+0.1$ \\
\hline $\mathrm{Ni}$ & $4.04 \mathrm{E}+02$ & $1.56 \mathrm{E}+02$ & $1.56 \mathrm{E}+01$ \\
\hline $\mathrm{NO}_{2}$ & $1.02 \mathrm{E}+02$ & $3.93 \mathrm{E}+01$ & $3.93 \mathrm{E}+00$ \\
\hline $\mathrm{NO}_{3}$ & $2.03 \mathrm{E}+03$ & $7.82 \mathrm{E}+02$ & $7.82 \mathrm{E}+01$ \\
\hline $\mathrm{OH}$ & $1.16 \mathrm{E}+04$ & $4.47 \mathrm{E}+03$ & $4.47 \mathrm{E}+02$ \\
\hline $\mathrm{Pb}$ & $1.09 \mathrm{E}+02$ & $4.20 \mathrm{E}+01$ & $4.20 \mathrm{E}+00$ \\
\hline $\mathrm{P}$ as $\mathrm{PO}_{4}$ & $2.78 \mathrm{E}+02$ & $1.07 \mathrm{E}+02$ & $1.07 \mathrm{E}+01$ \\
\hline $\mathrm{P}$ & $9.02 \mathrm{E}+01$ & $3.47 \mathrm{E}+01$ & $3.47 \mathrm{E}+00$ \\
\hline $\mathrm{Se}$ & $\mathrm{NR}$ & $\mathrm{NR}$ & $\mathrm{NR}$ \\
\hline $\mathrm{Si}$ as $\mathrm{SiO}_{3}$ & $5.04 \mathrm{E}+03$ & $1.94 \mathrm{E}+03$ & $1.94 \mathrm{E}+02$ \\
\hline $\mathrm{S}_{\text {as } \mathrm{SO}_{4}}$ & $3.43 \mathrm{E}+02$ & $1,32 \mathrm{E}+02$ & $1.32 \mathrm{E}+01$ \\
\hline $\mathrm{S}$ & $1.15 \mathrm{E}+02$ & $4.41 \mathrm{E}+01$ & $4.41 \mathrm{E}+00$ \\
\hline St & $2.90 \mathrm{E}+01$ & $1.12 E+01$ & $112 \mathrm{E}+00$ \\
\hline TOC & $\mathrm{NR}$ & $\mathrm{NR}$ & $\mathrm{NR}$ \\
\hline Total U & $1.12 \mathrm{E}-01$ & $4.33 \mathrm{E}-02$ & $4.33 \mathrm{E}-03$ \\
\hline
\end{tabular}


HNF-SD-HTI-TI-O01, REV. 0

SESC-EN-RPT-002, Rev. 1

(formaliy known as)

Table 6. Tank 241-AX-104 Nonradiological Waste Residual Inventory Following Retrieval (page 2 of 2)

\begin{tabular}{|l|c|r|r|}
\hline Residual Waste $(\mathrm{kg})$ & Case I & Case II & Case III \\
\hline Target $\left(\mathrm{m}^{3}\right)$ & 26.46 & 10.19 & 1.02 \\
\hline Sludge $\left(\mathrm{m}^{3}\right)$ & 26.46 & 10.19 & 1.02 \\
\hline Saltcake $\left(\mathrm{m}^{3}\right)$ & 0.00 & 0.00 & 0.00 \\
\hline $\mathrm{Zn}$ & $\mathrm{NR}$ & $\mathrm{NR}$ & $\mathrm{NR}$ \\
\hline $\mathrm{Zr}$ & $\mathrm{NR}$ & $\mathrm{NR}$ & $\mathrm{NR}$ \\
\hline $\mathrm{EDTA}$ & $\mathrm{NR}$ & $\mathrm{NR}$ & $\mathrm{NR}$ \\
\hline $\mathrm{NH}_{3}$ & $\mathrm{NR}$ & $\mathrm{NR}$ & $\mathrm{NR}$ \\
\hline $\mathrm{Cr}^{+6}$ & $\mathrm{NR}$ & $\mathrm{NR}$ & $\mathrm{NR}$ \\
\hline $\mathrm{CN}$ & $\mathrm{NR}$ & $\mathrm{NR}$ & $\mathrm{NR}$ \\
\hline $\mathrm{H}_{2} \mathrm{O}$ & $1.95 \mathrm{E}+04$ & $7.52 \mathrm{E}+03$ & $7.52 \mathrm{E}+02$ \\
\hline $\mathrm{Pu}$ & $1.35 \mathrm{E}+03$ & $5.19 \mathrm{E}+02$ & $5.19 \mathrm{E}+01$ \\
\hline
\end{tabular}

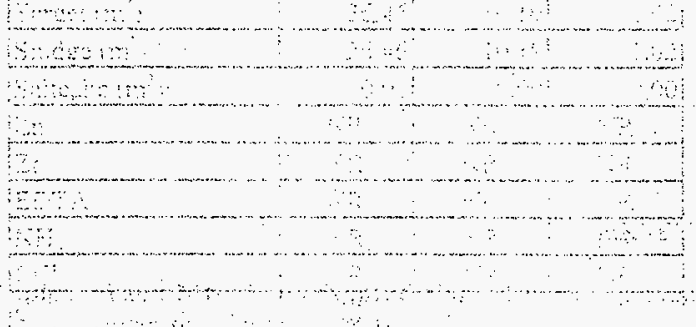


Table 7. Tank 241-AX-104 Radiological Waste Residual Inventory Following Retrieval (page 1 of 2)

\begin{tabular}{|c|c|c|c|}
\hline Resicual Waste (Ci) & Case I & Case II & Case III \\
\hline Decay & $12 / 31 / 99$ & $12 / 31 / 99=$ & $12 / 31 / 99$ \\
\hline${ }^{3} \mathrm{H}$ & $3.38 \mathrm{E}+00$ & $1.30 \mathrm{E}+00$ & $1.30 \mathrm{E}-01$ \\
\hline${ }^{14} \mathrm{C}$ & 6.30E-01 & $2.43 \mathrm{E}-01$ & $2.43 \mathrm{E}-02$ \\
\hline $59 \mathrm{Ni}$ & $3.12 \mathrm{E}+00$ & $1.20 \mathrm{E}+00$ & $1.20 \mathrm{E}-01$ \\
\hline${ }^{60} \mathrm{Co}$ & $1.57 \mathrm{E}+02$ & $6.06 \mathrm{E}+01$ & $6.06 \mathrm{E}+00$ \\
\hline${ }^{63} \mathrm{Ni}$ & $3.13 E+02$ & $1.21 \mathrm{E}+02$ & $1.21 \mathrm{E}+01$ \\
\hline${ }^{79} \mathrm{Se}$ & $2.95 \mathrm{E}+00$ & $1.14 \mathrm{E}+00$ & $1.14 \mathrm{E}-01$ \\
\hline${ }^{90} \mathrm{Sr}$ & $1.36 \mathrm{E}+06$ & $5.25 \mathrm{E}+05$ & $5.25 \mathrm{E}+04$ \\
\hline${ }^{90} \mathrm{Y}$ & $1.36 \mathrm{E}+06$ & $5.25 \mathrm{E}+05$ & $5.25 \mathrm{E}+04$ \\
\hline${ }^{93} \mathrm{mNb}$ & $1.02 \mathrm{E}+01$ & $3.93 \mathrm{E}+00$ & $3.93 \mathrm{E}-01$ \\
\hline${ }^{93} \mathrm{Zr}$ & $1.36 \mathrm{E}+01$ & $5.24 \mathrm{E}+00$ & $5.24 \mathrm{E}-01$ \\
\hline${ }^{99} \mathrm{Tc}$ & $4.47 \mathrm{E}+00$ & $1.72 \mathrm{E}+00$ & $1.72 \mathrm{E}-01$ \\
\hline${ }^{106} \mathrm{Ru}$ & \begin{tabular}{|l|}
$1.01 \mathrm{E}-02$ \\
\end{tabular} & $3.89 \mathrm{E}-03$ & $3.89 \mathrm{E}-04$ \\
\hline${ }^{113} \mathrm{mCd}$ & $5.82 \mathrm{E}+01$ & $2.24 \mathrm{E}+01$ & $2.24 \mathrm{E}+00$ \\
\hline${ }^{125} \mathrm{Sb}$ & $6.26 \mathrm{E}+01$ & $2.41 \mathrm{E}+01$ & $2.41 \mathrm{E}+00$ \\
\hline${ }^{126} \mathrm{Sn}$ & $4.61 \mathrm{E}+00$ & $1.78 \mathrm{E}+00$ & $1.78 \mathrm{E}-01$ \\
\hline${ }^{129} \mathrm{I}$ & $8.64 \mathrm{E}-03$ & $3.33 \mathrm{E}-03$ & $3.33 \mathrm{E}-04$ \\
\hline${ }^{134} \mathrm{Cs}$ & $2.07 \mathrm{E}-01$ & $7.98 \mathrm{E}-02$ & $7.98 \mathrm{E}-03$ \\
\hline${ }^{135} \mathrm{Cs}$ & NRR & $\mathrm{NR}$ & $\mathrm{NR}$ \\
\hline${ }^{137} \mathrm{Cs}$ & $2.83 \mathrm{E}+04$ & $1.09 \mathrm{E}+04$ & $1.09 E+03$ \\
\hline${ }^{137} \mathrm{mBa}$ & $2.66 \mathrm{E}+04$ & $1.03 \mathrm{E}+04$ & $1.03 E+03$ \\
\hline${ }^{151} \mathrm{Sm}:$ & $1.10 \mathrm{E}+04$ & $4.24 E+03$ & $4.24 \mathrm{E}+02$ \\
\hline${ }^{152} \mathrm{Eu}$ & $3.36 \mathrm{E}+00$ & $1.29 \mathrm{E}+00$ & $1.29 \mathrm{E}-01$ \\
\hline${ }^{154} \mathrm{Eu}$ & $1.15 \mathrm{E}+03$ & $4.42 \mathrm{E}+02$ & $4.42 \mathrm{E}+01$ \\
\hline${ }^{155} \mathrm{Eu}$ & $7.38 \mathrm{E}+02$ & $2.84 E+02$ & $2.84 \mathrm{E}+01$ \\
\hline${ }^{226} \mathrm{Ra}$ & $1.96 \mathrm{E}-04$ & $7.55 \mathrm{E}-05$ & $7.55 \mathrm{E}-06$ \\
\hline${ }^{227} \mathrm{Ac}$ & $1.06 \mathrm{E}-03$ & $4.08 \mathrm{E}-04$ & 4.08E-05 \\
\hline${ }^{228} \mathrm{Ra}$ & $1.77 \mathrm{E}-09$ & $6.82 \mathrm{E}-10$ & $6.82 \mathrm{E}-11$ \\
\hline${ }^{229} \mathrm{Th}$ & $2.77 \mathrm{E}-07$ & $1.07 \mathrm{E}-07$ & $1.07 \mathrm{E}-08$ \\
\hline${ }^{231} \mathrm{~Pa}$ & $2.38 \mathrm{E}-03$ & $9.17 \mathrm{E}-04$ & $9.17 \mathrm{E}-05$ \\
\hline${ }^{232} \mathrm{Th}$ & $1.60 \mathrm{E}-10$ & $6.16 \mathrm{E}-11$ & $6.16 \mathrm{E}-12$ \\
\hline${ }^{232} \mathrm{U}$ & 2.22E-07 & $8.55 \mathrm{E}-08$ & $8.55 \mathrm{E}-09$ \\
\hline${ }^{233} \mathrm{U}$ & 5.24E-09 & $2.02 \mathrm{E}-09$ & $2.02 \mathrm{E}-10$ \\
\hline${ }^{234} \mathrm{U}$ & $2.74 \mathrm{E}-03$ & $1.06 \mathrm{E}-03$ & $1.06 \mathrm{E}-04$ \\
\hline${ }^{235} \mathrm{U}$ & $1.14 \mathrm{E}-04$ & $4.39 \mathrm{E}-05$ & 4.39E-06 \\
\hline${ }^{236} \mathrm{U}$ & 7.47E-05 & $2.88 \mathrm{E}-05$ & $2.88 \mathrm{E}-06$ \\
\hline${ }^{237} \mathrm{~Np}$ & $9.54 \mathrm{E}-03$ & $3.68 \mathrm{E}-03$ & $3.68 \mathrm{E}-04$ \\
\hline
\end{tabular}


HNF-SD-HTI-TI-OOI, REV. 0

SESC-EN-RPT-002, Rev. 1

Table 7. Tank 241-AX-104 Radiological Waste Residual

(formally known as) Inventory following Retrieval (page 2 of 2)

\begin{tabular}{|l|c|c|c|}
\hline Residual Waste (Ci) & Case I & Case II & Case III \\
\hline Decay & $12 / 31 / 99$ & $12 / 31 / 99$ & $12 / 31 / 99$ \\
\hline${ }^{238} \mathrm{Pu}$ & $2.50 \mathrm{E}+00$ & $9.63 \mathrm{E}-01$ & $9.63 \mathrm{E}-02$ \\
\hline${ }^{238} \mathrm{U}$ & $2.67 \mathrm{E}-03$ & $1.03 \mathrm{E}-03$ & $1.03 \mathrm{E}-04$ \\
\hline${ }^{239} \mathrm{Pu}$ & $6.47 \mathrm{E}+01$ & $2.49 \mathrm{E}+01$ & $2.49 \mathrm{E}+00$ \\
\hline${ }^{240} \mathrm{Pu}$ & $1.23 \mathrm{E}+01$ & $4.74 \mathrm{E}+00$ & $4.74 \mathrm{E}-01$ \\
\hline${ }^{239 / 240} \mathrm{Pu}$ & $3.49 \mathrm{E}+02$ & $1.34 \mathrm{E}+02$ & $1.34 \mathrm{E}+01$ \\
\hline${ }^{24} \mathrm{Am}$ & $1.02 \mathrm{E}+02$ & $3.93 \mathrm{E}+01$ & $3.93 \mathrm{E}+00$ \\
\hline${ }^{241} \mathrm{Pu}$ & $1.78 \mathrm{E}+02$ & $6.86 \mathrm{E}+01$ & $6.86 \mathrm{E}+00$ \\
\hline${ }^{242} \mathrm{Cm}$ & $9.29 \mathrm{E}-02$ & $3.58 \mathrm{E}-02$ & $3.58 \mathrm{E}-03$ \\
\hline${ }^{242} \mathrm{mAm}$ & NR & NR & NR \\
\hline${ }^{242} \mathrm{Pu}$ & $1.03 \mathrm{E}-03$ & $3.97 \mathrm{E}-04$ & $3.97 \mathrm{E}-05$ \\
\hline${ }^{243} \mathrm{Am}$ & $3.12 \mathrm{E}-03$ & $1.20 \mathrm{E}-03$ & $1.20 \mathrm{E}-04$ \\
\hline${ }^{243} \mathrm{Cm}$ & $7.14 \mathrm{E}-03$ & $2.75 \mathrm{E}-03$ & $2.75 \mathrm{E}-04$ \\
\hline${ }^{244} \mathrm{Cm}$ & $2.19 \mathrm{E}-01$ & $8.44 \mathrm{E}-02$ & $8.44 \mathrm{E}-03$ \\
\hline Total & $2.79 \mathrm{E}+06$ & $1.08 \mathrm{E}+06$ & $1.08 \mathrm{E}+05$ \\
\hline
\end{tabular}


Table 8. Retrieval Scenario Product Solution Nonradiological Analyte Concentrations (page 1 of 2)

\begin{tabular}{|c|c|c|c|}
\hline Limiting Vol (L) & 0 & 193,725 & 302,998 \\
\hline Sludge [Solids Basis (L)] & 0 & 193,725 & 302,998 \\
\hline Saltcake [Na Basis (L)] & of & 13,102 & 20,493 \\
\hline Solution Concentrations (M) & Case I & Case II & Case III \\
\hline $\mathrm{Ag}$ & $\mathrm{NA}^{\prime}$ & NR & $\mathrm{NR}$ \\
\hline $\mathrm{Al}$ & $\mathrm{NA}$ & $2.09 \mathrm{E}-01$ & $2.09 \mathrm{E}-01$ \\
\hline As & NA & NR & NR \\
\hline $\mathrm{B}$ & NA & NR & NR \\
\hline $\mathrm{Ba}$ & NA & $1.76 \mathrm{E}-03$ & $1.76 \mathrm{E}-03$ \\
\hline $\mathrm{Bi}$ & NA. & NR & NR \\
\hline $\mathrm{Ca}$ & NA & $5.42 \mathrm{E}-02$ & $5.42 \mathrm{E}-02$ \\
\hline $\mathrm{Cd}$ & NA & $1.26 \mathrm{E}-03$ & $1.26 \mathrm{E}-03$ \\
\hline $\mathrm{Cl}$ & NA & $9.76 \mathrm{E}-03$ & $9.76 \mathrm{E}-03$ \\
\hline $\mathrm{TIC}$ as $\mathrm{CO}_{3}$ & $\mathrm{NA}$ & $2.04 \mathrm{E}-02$ & $2.04 \mathrm{E}-02$ \\
\hline $\mathrm{Cr}$ & $\mathrm{NA}$ & $5.12 \mathrm{E}-03$ & $5.12 E-03$ \\
\hline $\mathrm{Cu}$ & NA. & NR & NR \\
\hline$F$ & NA & NR & $\mathrm{NR}$ \\
\hline $\mathrm{Fe}$ & NA & $4.48 \mathrm{E}-01$ & $4.48 \mathrm{E}-01$ \\
\hline $\mathrm{Hg}$ & NA & $\mathrm{NR}$ & $\mathrm{NR}$ \\
\hline $\mathrm{K}$ & $\mathrm{NA}$ & $2.85 \mathrm{E}-01$ & $2.85 \mathrm{E}-01$ \\
\hline $\mathrm{La}$ & $\mathrm{NA}$ & $\mathrm{NR}$ & NR \\
\hline $\mathrm{Mg}$ & NA & $1.44 \mathrm{E}-02$ & $1.44 \mathrm{E}-02$ \\
\hline $\mathrm{Mn}$ & $\mathrm{NA}$ & $7.09 \mathrm{E}-03$ & $7.09 \mathrm{E}-03$ \\
\hline $\mathrm{Na}$ & $\mathrm{NA}$ & $3.38 \mathrm{E}-01$ & $3.38 \mathrm{E}-0 \mathrm{I}$ \\
\hline $\mathrm{Ni}$ & $\mathrm{NA}$ & $2.18 \mathrm{E}-02$ & $2.18 \mathrm{E}-02$ \\
\hline $\mathrm{NO}_{2}$ & NA & $7.04 \mathrm{E}-03$ & $7.04 \mathrm{E}-03$ \\
\hline $\mathrm{NO}_{3}$ & $\mathrm{NA}$ & $1.04 \mathrm{E}-01$ & $1.04 \mathrm{E}-01$ \\
\hline $\mathrm{OH}$ & NA & $2.16 \mathrm{E}+00$ & $2.16 \mathrm{E}+00$ \\
\hline $\mathrm{Pb}$ & $\mathrm{NA}$ & $1.67 \mathrm{E}-03$ & $1.67 \mathrm{E}-03$ \\
\hline $\mathrm{P}$ as $\mathrm{PO}_{4}$ & $\mathrm{NA}$ & $9.29 \mathrm{E}-03$ & 9.29E-03 \\
\hline $\mathrm{p}$ & $\mathrm{NA}$ & $9.24 \mathrm{E}-03$ & $9.24 \mathrm{E}-03$ \\
\hline $\mathrm{Se}$ & $\mathrm{NA}$ & $\mathrm{NR}$ & $\mathrm{NR}$ \\
\hline $\mathrm{Si}$ as $\mathrm{SiO}_{3}$ & $\mathrm{NA}$ & $2.10 \mathrm{E}-01$ & $2.10 \mathrm{E}-01$ \\
\hline $\mathrm{S}$ as $\mathrm{SO}_{4}$ & $\mathrm{NA}$ & $1.13 \mathrm{E}-02$ & $1.13 \mathrm{E}-02$ \\
\hline S & $\mathrm{NA}$ & $1.13 \mathrm{E}-02$ & $1.13 \mathrm{E}-02$ \\
\hline $\begin{array}{l}\mathrm{Sr} \\
\end{array}$ & NA & 1.05E-03 & 1.05E-03 \\
\hline
\end{tabular}

${ }^{1} \mathrm{NA}=$ Not Applicable, no retrieval required. 
HNF-SD-HTI-TI-001, REV. O

SESC-EN-RPT-002, Rev. 1

(formally known as)

Table 8. Retrieval Scenario Product Solution Nonradiological Analyte Concentrations (page 2 of 2)

\begin{tabular}{|c|c|c|c|}
\hline Limiting Vol (L) & 0 & 193,725 & 302,998 \\
\hline Sludge [Solids Basis (L)] & 0 & 193,725 & 302,998 \\
\hline Saltcake [Na Basis (L)] & 0 & 13,102 & 20,493 \\
\hline Solution Concentrations (M) & Case I & Case II & Case III \\
\hline TOC & NA & $\mathrm{NR}$ & NR \\
\hline Iotal U & NA & $1.50 \mathrm{E}-06$ & $1.50 \mathrm{E}-06$ \\
\hline $\mathrm{Zn}$ & NA & $\mathrm{NR}$ & NR \\
\hline $\mathrm{Zr}$ & NA & NR & $\mathrm{NR}:$ \\
\hline EDTA. & NA. & $\mathrm{NR}$ & NR \\
\hline $\mathrm{NH}_{3}$ & $\mathrm{NA}$ & $\mathrm{NR}$ & $\mathrm{NR}$ \\
\hline $\mathrm{Cr}^{+6}$ & $\mathrm{NA}$ & NR & $\mathrm{NR}$ \\
\hline CN: & NA & NR & NR \\
\hline $\mathrm{H}_{2} \mathrm{O}$ & $\mathrm{NA}$ & 3.44 & 3.44 \\
\hline Retrieval $\mathrm{H}_{2} \mathrm{O}$ & $\mathrm{NA}$ & 50.85 & 50.85 \\
\hline
\end{tabular}

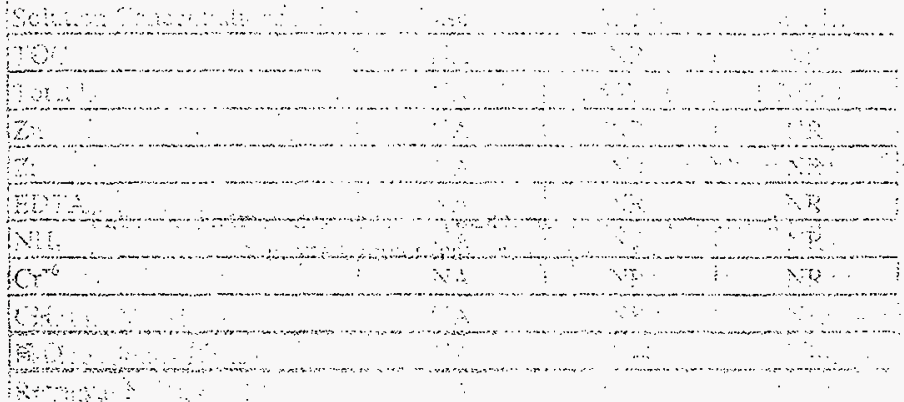


Table 9. Retrieval Scenario Product Solution Radiological Analyte Concentrations (page 1 of 2)

\begin{tabular}{|c|c|c|c|}
\hline Solution Concentrations $(\mathrm{Ci} / \mathrm{L})$ & Case I & Case II & Case III \\
\hline Decay & $12 / 31 / 99$ & $12 / 31 / 99$ & $12 / 31 / 99$ \\
\hline${ }^{3} \mathrm{H}$ & NA. & $1.07 \mathrm{E}-05$ & $1.07 \mathrm{E}-05$ \\
\hline${ }^{14} \mathrm{C}$ & $\mathrm{NA}$ & $2.00 \mathrm{E}-06$ & $2.00 \mathrm{E}-06$ \\
\hline${ }^{59} \mathrm{Ni}$ & NA & $9.90 \mathrm{E}-06$ & $9.90 \mathrm{E}-06$ \\
\hline${ }^{60} \mathrm{Co}$ & NA & $4.99 \mathrm{E}-04$ & 4.99E-04 \\
\hline${ }^{63} \mathrm{Ni}$ & NA & $9.93 \mathrm{E}-04$ & $9.93 \mathrm{E}-04$ \\
\hline${ }^{79} \mathrm{Se}$ & $\mathrm{NA}$ & $9.36 \mathrm{E}-06$ & $9.36 \mathrm{E}-06$ \\
\hline${ }^{90} \mathrm{Sr}$ & NA & $4.32 \mathrm{E}+00$ & $4.32 \mathrm{E}+00$ \\
\hline${ }^{90} \mathrm{Y}$ & NA & $4.32 \mathrm{E}+00$ & $4.32 \mathrm{E}+00$ \\
\hline${ }^{93} \mathrm{mNb}$ & NA & 3.24E-05 & $3.24 \mathrm{E}-05$ \\
\hline${ }^{93} \mathrm{Zr}-\mathrm{C}_{1}$ & NA & $4.32 \mathrm{E}-05$ & 4.32E-05 \\
\hline${ }^{99} \mathrm{Tc} \cdots$ & NA & $1.42 \mathrm{E}-05$ & $1.42 \mathrm{E}-05$ \\
\hline${ }^{106} \mathrm{Ru}$ & $\mathrm{NA}$ & $3.20 \mathrm{E}-08$ & $3.20 \mathrm{E}-08$ \\
\hline${ }^{113} \mathrm{mCd}$ & NA & $1.85 \mathrm{E}-04$ & $1.85 \mathrm{E}-04$ \\
\hline${ }^{125} \mathrm{Sb}$ & NA & $1.99 \mathrm{E}-04$ & $1.99 \mathrm{E}-04$ \\
\hline${ }^{126} \mathrm{Sn}$ & $\mathrm{NA}$ & $1.46 \mathrm{E}-05$ & $1.46 \mathrm{E}-05$ \\
\hline${ }^{129} \mathrm{I}$ & NA & $2.74 \mathrm{E}-08$ & $2.74 \mathrm{E}-08$ \\
\hline${ }^{134} \mathrm{Cs}$ & NA & $6.57 \mathrm{E}-0.7$ & $6.57 \mathrm{E}-07$ \\
\hline${ }^{135} \mathrm{Cs}$ & $\mathrm{NA}$ & $\mathrm{NR}$ & $\mathrm{NR}$ \\
\hline${ }^{137} \mathrm{Cs}$ & NA & $8.97 \mathrm{E}-02$ & 8.97E-02 \\
\hline${ }^{137} \mathrm{mBa}$ & $\mathrm{NA}$ & 8.44E- 02 & $8.44 \mathrm{E}-02$ \\
\hline${ }^{151} \mathrm{Sm}$ & $\mathrm{NA}$ & $3.49 \mathrm{E}-02$ & $3.49 \mathrm{E}-02$ \\
\hline${ }^{152} \mathrm{Eu}$ & $\mathrm{NA}$ & 1.07E-05 & $1.07 \mathrm{E}-05$ \\
\hline${ }^{154} \mathrm{Eu}$ & $\mathrm{NA}$ & $3.64 \mathrm{E}-03$ & $3.64 \mathrm{E}-03$ \\
\hline${ }^{155} \mathrm{Eu}$ & $\mathrm{NA}$ & $2.34 \mathrm{E}-03$ & $2.34 \mathrm{E}-03$ \\
\hline${ }^{226} \mathrm{Ra}$ & $\mathrm{NA}$ & $6.22 \mathrm{E}-10$ & $6.22 \mathrm{E}-10$ \\
\hline${ }^{227} \mathrm{AC}$ & $\mathrm{NA}$ & 3.36E-09 & $3.36 \mathrm{E}-09$ \\
\hline${ }^{228} \mathrm{Ra}$ & NA & $5.62 \mathrm{E}-15$ & $5.62 \mathrm{E}-15$ \\
\hline${ }^{229} \mathrm{Th}$ & $\mathrm{NA}$ & $8.79 \mathrm{E}-13$ & $8.79 \mathrm{E}-13$ \\
\hline${ }^{23 !} \mathrm{Pa}$ & NA & $7.55 \mathrm{E}-09$ & $7.55 \mathrm{E}-09$ \\
\hline${ }^{232} \mathrm{Th}$ & $\mathrm{NA}$ & $5.08 \mathrm{E}-16$ & $5.08 \mathrm{E}-16$ \\
\hline${ }^{232} \mathrm{U}$ & $\mathrm{NA}$ & $7.04 \mathrm{E}-13$ & $7.04 E-13$ \\
\hline${ }^{233} \mathrm{U}$ & $\mathrm{NA}$ & $1.66 \mathrm{E}-14$ & $1.66 \mathrm{E}-14$ \\
\hline${ }^{234} \mathrm{U}$ & $\mathrm{NA}$ & $8.69 \mathrm{E}-09$ & $8.69 \mathrm{E}-09$ \\
\hline${ }^{235} \mathrm{U}$ & NA & $3.62 \mathrm{E}-10$ & $3.62 \mathrm{E}-10$ \\
\hline${ }^{236} \mathrm{U}$ & $\mathrm{NA}$ & $2.37 \mathrm{E}-10$ & 2.37.E-10 \\
\hline${ }^{237} \mathrm{~Np}$ & $\mathrm{NA}$ & $3.03 \mathrm{E}-08$ & $3.03 \mathrm{E}-08$ \\
\hline
\end{tabular}


HNF-SD-HTI-TI-001，REV. 0

SESC-EN-RPT-002, Rev. 1

Table 9. Retrieval Scenario Product Solution Radiological ly known as) Analyte Concentrations (page 2 of 2)

\begin{tabular}{|l|c|c|c|}
\hline Solution Concentrations (Ci/L) & Case I & Case II & Case III \\
\hline Decay & $12 / 31 / 99$ & $12 / 31 / 99$ & $12 / 31 / 99$ \\
\hline${ }^{238} \mathrm{Pu}$ & NA & $7.93 \mathrm{E}-06$ & $7.93 \mathrm{E}-06$ \\
\hline${ }^{238} \mathrm{U}$ & NA & $8.47 \mathrm{E}-09$ & $8.47 \mathrm{E}-09$ \\
\hline${ }^{239} \mathrm{Pu}$ & NA & $2.05 \mathrm{E}-04$ & $2.05 \mathrm{E}-04$ \\
\hline${ }^{240} \mathrm{Pu}$ & NA & $3.90 \mathrm{E}-05$ & $3.90 \mathrm{E}-05$ \\
\hline${ }^{239 / 240} \mathrm{Pu}$ & NA & $1.11 \mathrm{E}-03$ & $1.11 \mathrm{E}-03$ \\
\hline${ }^{241} \mathrm{Am}$ & NA & $3.24 \mathrm{E}-04$ & $3.24 \mathrm{E}-04$ \\
\hline${ }^{241} \mathrm{Pu}$ & NA & $5.65 \mathrm{E}-04$ & $5.65 \mathrm{E}-04$ \\
\hline${ }^{242} \mathrm{Cm}$ & NA & $2.95 \mathrm{E}-07$ & $2.95 \mathrm{E}-07$ \\
\hline${ }^{242} \mathrm{Pu}$ & NA & NR & NR \\
\hline${ }^{243} \mathrm{Am}$ & NA & $3.27 \mathrm{E}-09$ & $3.27 \mathrm{E}-09$ \\
\hline${ }^{243} \mathrm{Cm}$ & NA & $9.90 \mathrm{E}-09$ & $9.90 \mathrm{E}-09$ \\
\hline${ }^{244} \mathrm{Cm}$ & NA & $2.27 \mathrm{E}-08$ & $2.27 \mathrm{E}-08$ \\
\hline
\end{tabular}

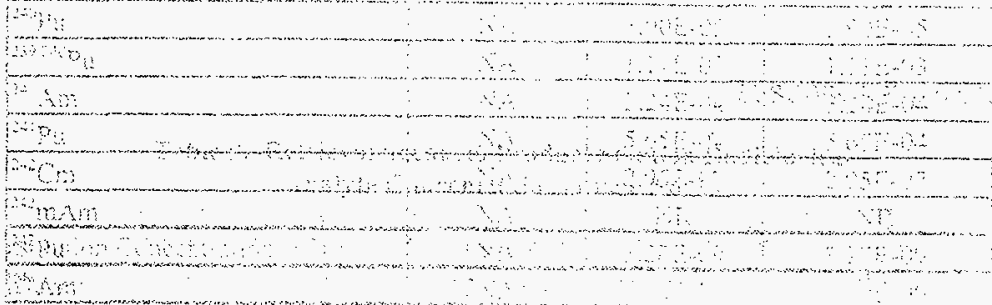


Table 10. Tank 241-AX-104 Retrieval Scenario Nonradiological Constituent Leakage Estimate (page 1 of 2)

\begin{tabular}{|c|c|c|c|c|c|c|}
\hline \begin{tabular}{|l|} 
Release \\
Volume (L) \\
\end{tabular} & 0 & 30,283 & 30,283 & 0 & $\quad 151,413$ & 151,413 \\
\hline Analyte $(\mathrm{kg})$ & Case I & Case II & Case III & Case I & Case II & Case III \\
\hline $\mathrm{Ag}$ & NA & $N R$ & NR & $\mathrm{NA}$ & $\mathrm{NR}$ & NR \\
\hline Al & NA & $1.71 \mathrm{E}+02$ & $1.71 \mathrm{E}+02$ & NA & $8.55 \mathrm{E}+02$ & $8.55 \mathrm{E}+02$ \\
\hline As & $\mathrm{NA}$ & $\mathrm{NR}$ & NR & NA & NR & NR \\
\hline$B$ & NA & NR & $\mathrm{NR}$ & NA & NR & NR \\
\hline $\mathrm{Ba}$ & $\mathrm{NA}$ & $7.33 \mathrm{E}+00$ & $7.33 \mathrm{E}+00$ & NA & 3.67E+01 & $3.67 \mathrm{E}+01$ \\
\hline $\mathrm{Bi}$ & NA & $\mathrm{NR}$ & NR & NA & $\mathrm{NR}$ & NR \\
\hline $\mathrm{Ca}$ & NA & $6.57 \mathrm{E}+01$ & $6.57 \mathrm{E}+01$ & $\mathrm{NA}$ & $3.29 \mathrm{E}+02$ & $3.29 E+02$ \\
\hline $\mathrm{Cd}$ & NA & $4.29 \mathrm{E}+00$ & $4.29 \mathrm{E}+00$ & NA & 2. $14 \mathrm{E}+01$ & $2.14 \mathrm{E}+01$ \\
\hline $\mathrm{Cl}$ & NA & $1.05 \mathrm{E}+01$ & $1.05 \mathrm{E}+01$ & $\mathrm{NA}$ & $5.24 \mathrm{E}+01$ & $5.24 \mathrm{E}+01$ \\
\hline $\mathrm{TIC}$ as $\mathrm{CO}_{3}$ & NA & $3.71 \mathrm{E}+01$ & $3.71 \mathrm{E}+01$ & $\mathrm{NA}$ & $1.85 \mathrm{E}+02$ & $1.85 \mathrm{E}+02$ \\
\hline $\mathrm{Cr}$ & $\mathrm{NA}$ & $8.06 \mathrm{E}+00$ & $8.06 \mathrm{E}+00$ & $\mathrm{NA}$ & $4,03 \mathrm{E}+01$ & $4.03 \mathrm{E}+01$ \\
\hline $\mathrm{Cu}$ & $\mathrm{NA}$ & NR & NR & NA & $\mathrm{NR}$ & $\mathrm{NR}$ \\
\hline$F$ & NA & NR & NR & $\mathrm{NA}$ & $\mathrm{NR}$ & NR \\
\hline $\mathrm{Fe}$ & $\mathrm{NA}$ & $7.58 \mathrm{E}+02$ & $7.58 \mathrm{E}+02$ & $\mathrm{NA}$ & $3.79 E+03$ & $3.79 E+03$ \\
\hline $\mathrm{Hg}$ & $\mathrm{NA}$ & NR & NR & NA & $\mathrm{NR}$ & NR \\
\hline $\mathrm{K}$ & $\mathrm{NA}$ & $3.38 \mathrm{E}+02$ & $3.38 \mathrm{E}+02$ & NA & $1.69 \mathrm{E}+03$ & $1.69 \mathrm{E}+03$ \\
\hline $\mathrm{La}$ & NA & NR & NR & NA & $\mathrm{NR}$ & NR \\
\hline $\mathrm{Mg}$ & NA & $1.06 \mathrm{E}+01$ & $1.06 \mathrm{E}+01$ & NA & $5.28 \mathrm{E}+01$ & $5.28 \mathrm{E}+01$ \\
\hline $\mathrm{Mn}$ & NA & $1.18 \mathrm{E}+01$ & $1.18 \mathrm{E}+01$ & NA & $5.90 \mathrm{E}+01$ & $5.90 \mathrm{E}+01$ \\
\hline $\mathrm{Na}$ & $\mathrm{NA}$ & $2.35 E+02$ & $2.35 \mathrm{E}+02$ & NA & $1,18 \mathrm{E}+03$ & $1.18 \mathrm{E}+03$ \\
\hline $\mathrm{Ni}$ & $\mathrm{NA}$ & $3.88 \mathrm{E}+01$ & $3.88 \mathrm{E}+01$ & NA & $194 \mathrm{E}+02$ & $1.94 \mathrm{E}+02$ \\
\hline $\mathrm{NO}_{2}$ & $\mathrm{NA}$ & $9.80 \mathrm{E}+00$ & $9.80 \mathrm{E}+00$ & $\mathrm{NA}$ & $4.90 \mathrm{E}+01$ & $4.90 \mathrm{E}+01$ \\
\hline $\mathrm{NO}_{3}$ & $\mathrm{NA}$ & $1.95 \mathrm{E}+02$ & $1.95 E+02$ & NA & $9.75 E+02$ & $9.75 \mathrm{E}+02$ \\
\hline $\mathrm{OH}$ & $\mathrm{NA}$ & $1.11 E+03$ & $1.11 \mathrm{E}+03$ & NA & $5.57 \mathrm{E}+03$ & $5.57 \mathrm{E}+03$ \\
\hline $\mathrm{Pb}$ & $\mathrm{NA}$ & $1.05 \mathrm{E}+01$ & $1.05 \mathrm{E}+01$ & $\mathrm{NA}$ & $5.24 \mathrm{E}+01$ & $5.24 \mathrm{E}+01$ \\
\hline $\mathrm{P}$ as $\mathrm{PO}_{4}$ & $\mathrm{NA}$ & $2.67 \mathrm{E}+01$ & $2.67 \mathrm{E}+01$ & $\mathrm{NA}$ & $1.34 \mathrm{E}+02$ & $1.34 \mathrm{E}+02$ \\
\hline$P$ & NA & $8.66 \mathrm{E}+00$ & $8.66 \mathrm{E}+00$ & NA & $4.33 \mathrm{E}+01$ & $4.33 E+01$ \\
\hline $\mathrm{Se}$ & NA & NR & NR & $\mathrm{NA}$ & $\mathrm{NR}$ & NR \\
\hline $\mathrm{Si}$ as $\mathrm{SiO}_{3}$ & NA & $4.84 \mathrm{E}+02$ & $4.84 \mathrm{E}+02$ & NA & $2.42 \mathrm{E}+03$ & $2.42 \mathrm{E}+03$ \\
\hline $\mathrm{S}$ as $\mathrm{SO}_{4}$ & NA & $3.30 \mathrm{E}+01$ & $3.30 \mathrm{E}+01$ & $\mathrm{NA}$ & $1.65 \mathrm{E}+02$ & $1.65 \mathrm{E}+02$ \\
\hline$S$ & NA & $1.10 \mathrm{E}+01$ & $1.10 \mathrm{E}+01$ & NA & $5.50 \mathrm{E}+01$ & $5.50 \mathrm{E}+01$ \\
\hline $\mathrm{Sr}$ & NA & $2.79 \mathrm{E}+00$ & $2.79 \mathrm{E}+00$ & $\mathrm{NA}$ & $1.39 \mathrm{E}+01$ & $1.39 \mathrm{E}+01$ \\
\hline TOC & $\mathrm{NA}$ & $\mathrm{NR}$ & NR & $\mathrm{NA}$ & $\mathrm{NR}$ & NR \\
\hline Total U & NA & $1.08 \mathrm{E}-02$ & $1.08 \mathrm{E}-02$ & $\mathrm{NA}$ & $5.40 \mathrm{E}-02$ & $5.40 \mathrm{E}-02$ \\
\hline $\mathrm{Zn}$ & NA & NR & $\mathrm{NR}$ & $\mathrm{NA}$ & NR & NR \\
\hline
\end{tabular}


HNF-SD-HTI-TI-001, REY. 0

SESC-EN-RPT-002, Rev. 1

Table 10. Tank 241-AX-104 Retrieval Scenario Nonradiological

(formally known as)

Constituent Leakage Estimate (page 2 of 2)

\begin{tabular}{|l|c|c|c|c|c|c|}
\hline $\begin{array}{l}\text { Release } \\
\text { Volume (L) }\end{array}$ & 0 & 30,283 & 30,283 & 0 & 151,413 & 151,413 \\
\hline Analyte (kg) & Case I & Case II & Case III & Case I & Case II & Case III \\
\hline $\mathrm{Zr}$ & $\mathrm{NA}$ & $\mathrm{NR}$ & $\mathrm{NR}$ & $\mathrm{NA}$ & $\mathrm{NR}$ & $\mathrm{NR}$ \\
\hline $\mathrm{EDTA}$ & $\mathrm{NA}$ & $\mathrm{NR}$ & $\mathrm{NR}$ & $\mathrm{NA}$ & $\mathrm{NR}$ & $\mathrm{NR}$ \\
\hline $\mathrm{NH}_{3}$ & $\mathrm{NA}$ & $\mathrm{NR}$ & $\mathrm{NR}$ & $\mathrm{NA}$ & $\mathrm{NR}$ & $\mathrm{NR}$ \\
\hline $\mathrm{Cr}^{+6}$ & $\mathrm{NA}$ & $\mathrm{NR}$ & $\mathrm{NR}$ & $\mathrm{NA}$ & $\mathrm{NR}$ & $\mathrm{NR}$ \\
\hline $\mathrm{CN}$ & $\mathrm{NA}$ & $\mathrm{NR}$ & $\mathrm{NR}$ & $\mathrm{NA}$ & $\mathrm{NR}$ & $\mathrm{NR}$ \\
\hline $\mathrm{H}_{2} \mathrm{O}$ & $\mathrm{NA}$ & $1.88 \mathrm{E}+03$ & $1.88 \mathrm{E}+03$ & $\mathrm{NA}$ & $9.38 \mathrm{E}+03$ & $9.38 \mathrm{E}+03$ \\
\hline $\begin{array}{l}\text { Retrieval } \\
\text { water }\end{array}$ & $\mathrm{NA}$ & $2.77 \mathrm{E}+04$ & $2.77 \mathrm{E}+04$ & $\mathrm{NA}$ & $1.39 \mathrm{E}+05$ & $1.39 \mathrm{E}+05$ \\
\hline Total $(\mathrm{kg})$ & & $3.32 \mathrm{E}+04$ & $3.32 \mathrm{E}+04$ & & $1.66 \mathrm{E}+05$ & $1.66 \mathrm{E}+05$ \\
\hline
\end{tabular}




\section{Table 11. Tank 241-AX-104 Retrieval Scenario Radiological Constituent Leakage Estimate (page 1 of 2)}

\begin{tabular}{|c|c|c|c|c|c|c|}
\hline $\begin{array}{l}\text { Release } \\
\text { Volume (L) }\end{array}$ & 0 & 30,283 & 30,283 & 0 & 151,413 & 151,413 \\
\hline Analyte (Ci) & Case I & Case II & Case III & Case I : & Case II & Case III \\
\hline Decay & $12 / 31 / 99$ & $12 / 31 / 99$ & $12 / 31 / 99$ & $12 / 31 / 99$ & $12 / 31 / 99$ & $12 / 31 / 99$ \\
\hline${ }^{3} \mathrm{H}$ & $\mathrm{NA}$ & $3.25 \mathrm{E}-01$ & $3.25 \mathrm{E}-01$ & $\mathrm{NA}$ & $1.62 \mathrm{E}+00$ & $1.62 \mathrm{E}+00$ \\
\hline${ }^{14} \mathrm{C}$ & $\mathrm{NA}$ & $6.05 \mathrm{E}-02$ & $6.05 \mathrm{E}-02$ & $\mathrm{NA}$ & $3.03 E-01$ & $3.03 \mathrm{E}-01$ \\
\hline${ }^{59} \mathrm{Ni}$ & $\mathrm{NA}$ & $3.00 \mathrm{E}-01$ & $3.00 \mathrm{E}-01$ & $\mathrm{NA}$ & $1.50 \mathrm{E}+00$ & $1.50 \mathrm{E}+00$ \\
\hline${ }^{60} \mathrm{Co}$ & $\mathrm{NA}$ & $1.51 \mathrm{E}+01$ & $1.51 E+01$ & $\mathrm{NA}$ & $7.55 \mathrm{E}+01$ & $7.55 \mathrm{E}+01$ \\
\hline${ }^{63} \mathrm{Ni}$ & $\mathrm{NA}$ & $3.01 \mathrm{E}+01$ & $3.01 \mathrm{E}+01$ & $\mathrm{NA}$ & $1.50 \mathrm{E}+02$ & $1.50 \mathrm{E}+02$ \\
\hline${ }^{79} \mathrm{Se}$ & $\mathrm{NA}$ & $2.83 \mathrm{E}-01$ & $2.83 \mathrm{E}-01$ & $\mathrm{NA}$ & $1.42 \mathrm{E}+00$ & $1.42 \mathrm{E}+00$ \\
\hline${ }^{90} \mathrm{Sr}$ & $\mathrm{NA}$ & $1.31 \mathrm{E}+05$ & $1.31 \mathrm{E}+05$ & $\mathrm{NA}$ & $6.55 \mathrm{E}+05$ & $6.55 \mathrm{E}+05$ \\
\hline${ }^{90} \mathrm{Y}$ & $\mathrm{NA}$ & $1.31 \mathrm{E}+05$ & $1.31 E+05$ & $\mathrm{NA}$ & $6.55 E+05$ & $6.55 \mathrm{E}+05$ \\
\hline${ }^{93} \mathrm{mNb}$ & $\mathrm{NA}$ & $9.80 \mathrm{E}-01$ & $9.80 \mathrm{E}-01$ & $\mathrm{NA}$ & $4.90 \mathrm{E}+00$ & $4.90 \mathrm{E}+00$ \\
\hline${ }^{93} \mathrm{Zr}$ & $\mathrm{NA}$ & $1.31 \mathrm{E}+00$ & $1.31 \mathrm{E}+00$ & $\mathrm{NA}$ & $6.53 E+00$ & $6.53 \mathrm{E}+00$ \\
\hline${ }^{99} \mathrm{Tc}$ & $\mathrm{NA}$ & $4.30 \mathrm{E}-01$ & $4.30 \mathrm{E}-01$ & $\mathrm{NA}$ & $2.15 \mathrm{E}+00$ & $2.15 \mathrm{E}+00$ \\
\hline${ }^{106} \mathrm{Ru}$ & $\mathrm{NA}$ & $9.71 \mathrm{E}-04$ & $9.71 \mathrm{E}-04$ & $\mathrm{NA}$ & $4.85 \mathrm{E}-03$ & $4.85 \mathrm{E}-03$ \\
\hline${ }^{113} \mathrm{mCd}$ & NA & $5.59 \mathrm{E}+00$ & $5.59 \mathrm{E}+00$ & $\mathrm{NA}$ & $2.80 E+01$ & $2.80 \mathrm{E}+01$ \\
\hline${ }^{125} \mathrm{Sb}$ & $\mathrm{NA}$ & $6.02 \mathrm{E}+00$ & $6.02 \mathrm{E}+00$ & NA & $3.01 E+01$ & $3.01 \mathrm{E}+01$ \\
\hline${ }^{126} \mathrm{Sn}$ & $\mathrm{NA}$ & $4.43 \mathrm{E}-01$ & $4.43 \mathrm{E}-01$ & NA & $2.21 \mathrm{E}+00$ & $2.21 \mathrm{E}+00$ \\
\hline${ }^{129} \mathrm{I}$ & NA & 8.30E-04 & $8.30 \mathrm{E}-04$ & $\mathrm{NA}$ & $4.15 E-03$ & $4.15 \mathrm{E}-03$ \\
\hline${ }^{134} \mathrm{Cs}$ & $\mathrm{NA}$ & $1.99 \mathrm{E}-02$ & $1.99 E-02$ & NA & $9.95 \mathrm{E}-02$ & 9.95E-02 \\
\hline${ }^{135} \mathrm{Cs}$ & $\mathrm{NA}$ & $\mathrm{NR}$ & NR & NA & NR & NR \\
\hline${ }^{137} \mathrm{Cs}$ & $\mathrm{NA}$ & $2.72 E+03$ & $2.72 \mathrm{E}+03$ & $\mathrm{NA}$ & $1.36 \mathrm{E}+04$ & $1.36 \mathrm{E}+04$ \\
\hline${ }^{137} \mathrm{mBa}$ & $\mathrm{NA}$ & $2.56 \mathrm{E}+03$ & $2.56 \mathrm{E}+03$ & $\mathrm{NA}$ & $1.28 \mathrm{E}+04$ & $1.28 \mathrm{E}+04$ \\
\hline${ }^{151} \mathrm{Sm}$ & $\mathrm{NA}$ & $1.06 \mathrm{E}+03$ & $1.06 \mathrm{E}+03$ & NA & $5.29 E+03$ & $5.29 \mathrm{E}+03$ \\
\hline${ }^{152} \mathrm{Eu}$ & $\mathrm{NA}$ & $3.23 \mathrm{E}-01$ & $3.23 \mathrm{E}-01$ & $\mathrm{NA}$ & $1.61 \mathrm{E} \div 00$ & $1.61 \mathrm{E}+00$ \\
\hline${ }^{154} \mathrm{Eu}$ & $\mathrm{NA}$ & $1.10 \mathrm{E}+02$ & $1.10 \mathrm{E}+02$ & $\mathrm{NA}$ & $5.51 \mathrm{E}+02$ & $5.51 \mathrm{E}+02$ \\
\hline${ }^{155} \mathrm{Eu}$ & $\mathrm{NA}$ & $7.09 \mathrm{E}+01$ & $7.09 E+01$ & $\mathrm{NA}$ & $3.54 \mathrm{E}+02$ & $3.54 \mathrm{E}+02$ \\
\hline${ }^{226} \mathrm{Ra}$ & $\mathrm{NA}$ & $1.88 \mathrm{E}-05$ & $1.88 \mathrm{E}-05$ & $\mathrm{NA}$ & $9.42 \mathrm{E}-05$ & $9.42 \mathrm{E}-05$ \\
\hline${ }^{227} \mathrm{Ac}$ & $\mathrm{NA}$ & $1.02 \mathrm{E}-04$ & $1.02 \mathrm{E}-04$ & $\mathrm{NA}$ & $5.09 \mathrm{E}-04$ & $5.09 \mathrm{E}-04$ \\
\hline${ }^{228} \mathrm{Ra}$ & $\mathrm{NA}$ & $1.70 \mathrm{E}-10$ & $1.70 \mathrm{E}-10$ & $\mathrm{NA}$ & $8.50 \mathrm{E}-10$ & $8.50 \mathrm{E}-10$ \\
\hline${ }^{229} \mathrm{Th}$ & $\mathrm{NA}$ & $2.66 \mathrm{E}-08$ & $2.66 \mathrm{E}-08$ & $\mathrm{NA}$ & $1.33 \mathrm{E}-07$ & $1.33 \mathrm{E}-07$ \\
\hline${ }^{23 \mathrm{i}} \mathrm{Pa}$ & NA & $2.29 \mathrm{E}-04$ & $2.29 \mathrm{E}-04$ & $\mathrm{NA}$ & $1.14 \mathrm{E}-03$ & $1.14 \mathrm{E}-03$ \\
\hline${ }^{232} \mathrm{Th}$ & $\mathrm{NA}$ & $1.54 \mathrm{E}-11$ & $1.54 \mathrm{E}-11$ & $\mathrm{NA}$ & $7.69 \mathrm{E}-11$ & $7.69 \mathrm{E}-11$ \\
\hline${ }^{232} \mathrm{U}$ & $\mathrm{NA}$ & $2.13 \mathrm{E}-08$ & $2.13 \mathrm{E}-08$ & $\mathrm{NA}$ & $1.07 \mathrm{E}-07$ & $1.07 \mathrm{E}-07$ \\
\hline${ }^{233} \mathrm{U}$ & $\mathrm{NA}$ & $5.04 \mathrm{E}-10$ & $5.04 \mathrm{E}-10$ & NA & $2.52 \mathrm{E}-09$ & $2.52 \mathrm{E}-09$ \\
\hline${ }^{234} \mathrm{U}$ & $\mathrm{NA}$ & $2.63 \mathrm{E}-04$ & $2.63 \mathrm{E}-04$ & $\mathrm{NA}$ & 1.32E-03 & $1.32 \mathrm{E}-03$ \\
\hline${ }^{235} \mathrm{U}$ & NA. & $1.10 \mathrm{E}-05$ & $1.10 \mathrm{E}-05$ & $\mathrm{NA}$ & $5.48 \mathrm{E}-05$ & $5.48 \mathrm{E}-05$ \\
\hline
\end{tabular}


HNF-SD-HTI-TI-00I, REV. 0

SESC-EN-RPT-002, Rev. 1

Table 11. Tank 241-AX-104 Retrieval Scenario Radiological (formally known as)

Constituent Leakage Estimate (page 2 of 2)

\begin{tabular}{|c|c|c|c|c|c|c|}
\hline $\begin{array}{l}\text { Release } \\
\text { Volume (L) }\end{array}$ & $\underline{0}$ & 30,283 & 30,283 & 0 & 151,413 & 151,413 \\
\hline Analyte (Ci) & Case I & Case II & Case III & Case I & Case II & Case III \\
\hline Decay & $12 / 31 / 99$ & $12 / 31 / 99$ & $12 / 31 / 99$ & $12 / 31 / 99$ & $12 / 31 / 99$ & $12 / 31 / 99$ \\
\hline${ }^{236} \mathrm{U}$ & $\mathrm{NA}$ & $7.18 \mathrm{E}-06$ & $7.18 \mathrm{E}-06$ & NA. & $3.59 \mathrm{E}-05$ & $3.59 \mathrm{E}-05$ \\
\hline${ }^{237} \mathrm{~Np}$ & $\mathrm{NA}$ & $9.17 \mathrm{E}-04$ & $9.17 \mathrm{E}-04$ & $\mathrm{NA}$ & $4.58 \mathrm{E}-03$ & $4.58 \mathrm{E}-03$ \\
\hline${ }^{238} \mathrm{Pu}$ & $\mathrm{NA}$ & $2.40 \mathrm{E}-01$ & $2.40 \mathrm{E}-01$ & $\mathrm{NA}$ & $1.20 \mathrm{E}+00$ & $1.20 \mathrm{E}+00$ \\
\hline${ }^{238} \mathrm{U}$ & $\mathrm{NA}$ & $2.57 \mathrm{E}-04$ & $2.57 \mathrm{E}-04$ & $\mathrm{NA}$ & $1: 28 \mathrm{E}-03$ & $1.28 \mathrm{E}-03$ \\
\hline${ }^{239} \mathrm{Pu}$ & $\mathrm{NA}$ & $6.22 \mathrm{E}+00$ & $6.22 \mathrm{E}+00$ & $\mathrm{NA}$ & $3.11 \mathrm{E}+01$ & $3.11 E+01$ \\
\hline${ }^{240} \mathrm{Pu}$ & $\mathrm{NA}$ & $1.18 \mathrm{E}+00^{\circ}$ & $118 \mathrm{E}+00^{-1}$ & $\mathrm{NA}$ & $5.91 \mathrm{E}+00$ & $5.91 \mathrm{E}+00$ \\
\hline${ }^{239 / 240} \mathrm{Pu}$ & $\mathrm{NA}$ & $3.35 \mathrm{E}+01$ & $3.35 \mathrm{E}+01$ & NA & $1.67 \mathrm{E}+02$ & $1.67 \mathrm{E}+02$ \\
\hline Am & $\mathrm{NA}$ & $9.80 \mathrm{E}+00$ & $9.80 \mathrm{E}+00$ & NA & $4.90 \mathrm{E}+01$ & $4.90 \mathrm{E}+01$ \\
\hline${ }^{241}$ puns:t! & NA & $1.71 \mathrm{E}+01$ & $1.71 \mathrm{E}+01$ & $\mathrm{NA}$ & 8.55E+01 & $8.55 \mathrm{E}+01$ \\
\hline${ }^{242} \mathrm{Cm}$ & $\mathrm{NA}$ & 8.9.3E-03 & $8.93 \mathrm{E}-03$ & $\mathrm{NA}$ & $4.46 \mathrm{E}-02$ & $4.46 \mathrm{E}-02$ \\
\hline${ }^{242} \mathrm{mAm}$ & $\mathrm{NA}$ & $\mathrm{NR}$ & NR & $\mathrm{NA}$ & NR & $\mathrm{NR}$ \\
\hline${ }^{242} \mathrm{Pu}$ & $\mathrm{NA}$ & $9.90 \mathrm{E}-05$ & $9.90 \mathrm{E}-05$ & $\mathrm{NA}$ & $4.95 \mathrm{E}-04$ & $4.95 \mathrm{E}-04$ \\
\hline${ }^{243} \mathrm{Am}$ & NA & $3.00 \mathrm{E}-04$ & $3.00 \mathrm{E}-04$ & $\mathrm{NA}$ & $1.50 \mathrm{E}-03$ & $1.50 \mathrm{E}-03$ \\
\hline${ }^{243} \mathrm{Cm}$ & $\mathrm{NA}$ & $6.86 \mathrm{E}-04$ & $6.86 \mathrm{E}-04$ & $\mathrm{NA}$ & $343 \mathrm{E}-03$ & $3.43 \mathrm{E}-03$ \\
\hline${ }^{244} \mathrm{Cm}$ & $\mathrm{NA}$ & $2.10 \mathrm{E}-02$ & $210 \mathrm{E}-02$ & $\mathrm{NA}$ & $1.05 \mathrm{E}=01$ & $1.05 \mathrm{E}-01$ \\
\hline Total & . & $268 \mathrm{E}+05$ & $2.68 \mathrm{E}+05$ & & $134 \mathrm{E}+06$ & $1.34 \mathrm{E}+06$ \\
\hline
\end{tabular}

in

(1)

as!

Mens?

m.

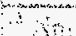

$\therefore$

"1

and

ET-11b 
HNF-SD-HTI-TI-001, REV. 0

SESC-EN-RPT-002, Rev. 1

(formaliy known as)

Table 12. Supernate Transfers to Tank 241-AX-104

\begin{tabular}{|c|c|c|l|l|}
\hline Date & $\begin{array}{c}\text { Transfer Volume, } \\
\mathrm{kL}(\mathrm{kgal})\end{array}$ & $\begin{array}{c}\text { Total Volume in } \\
\text { Tank 241-AX-104, } \\
\mathrm{kL}(\mathrm{kgal})\end{array}$ & Waste Type & Source \\
\hline $4^{\text {th }}$ Quarter 1972 & $2,146(567)$ & $2,525(667)$ & AR Supernate & $241-\mathrm{A}-104$ \\
\hline $1^{\text {st }}$ Quarter 1973 & $1,010(267)$ & $3,123(825)$ & AR Supernate & $241-\mathrm{A}-104$ \\
\hline $3^{\text {rd }}$ Quarter 1974 & $553(146)$ & $973(257)$ & Water & Water \\
\hline $3^{\text {rd }}$ Quarter 1974 & $1,688(446)$ & $2,660(703)$ & AR Supernate & 241-A-104 \\
\hline $3^{\text {rd }}$ Quarter 1974 & $227(60)$ & $2,888(763)$ & $\begin{array}{l}\text { AR/BL } \\
\text { Supernate }\end{array}$ & $241-\mathrm{AX}-103$ \\
\hline
\end{tabular}


Table 13. Estimated Supernate Composition in Equilibrium with Solids in Tank 241-AX-104 during the Fourth Quarter of 1972

\begin{tabular}{|c|c|c|}
\hline Component/Radionuclide & $\begin{array}{c}1977 \text { Wash Solution } \\
\text { Concentration }{ }^{2}, u g / g(u C i / g)\end{array}$ & $\begin{array}{l}\text { Tank Supernate Composition, } \\
\mathrm{ug} / \mathrm{ml}(\mathrm{uCi} / \mathrm{ml})\end{array}$ \\
\hline Al & 195 & 262 \\
\hline $\mathrm{NO}_{3}$ & 3,100 & 4,163 \\
\hline $\mathrm{NO}_{2}$ & 2,120 & 2847 \\
\hline $\mathrm{Na}$ & 4,310 & 5,788 \\
\hline $\mathrm{SO}_{4}$ & 530 & 712 \\
\hline${ }^{90} \mathrm{Sr}$ & $4.38^{6} \mathrm{uCi} / \mathrm{g}$ & $5.89 \mathrm{uCi} / \mathrm{ml}$ \\
\hline${ }^{137} \mathrm{Cs}$ & $2.61^{\mathrm{b}} \mathrm{uCi} / \mathrm{g}$ & $3.50 \mathrm{uCi} / \mathrm{ml}$ \\
\hline \multicolumn{3}{|c|}{$\begin{array}{l}\text { Wash solution composition based on mass of washed solids (Starr 1977) } \\
\text { Decayed to December } 31,1999 \\
\text { Based on } 178 \mathrm{~kL} \text { ( } 47 \mathrm{kgal} \text { ) of sludge, with an average density of } 1.8 \mathrm{~kg} / \mathrm{L} \text { and } 238 \mathrm{~kL} \\
\text { (63 kgal) of supernate in equilibrium with this sludge }\end{array}$} \\
\hline Mane 2 & & \\
\hline
\end{tabular}

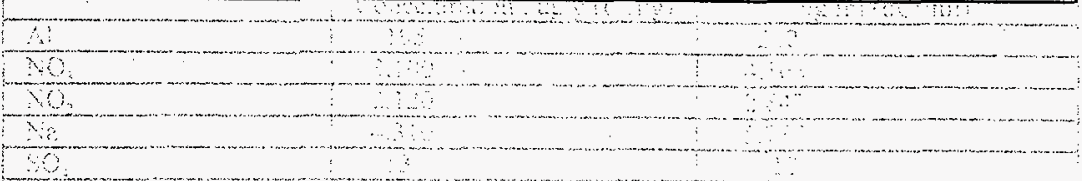


Table 14. Composition of Tank 241-A-104 Supernate, Composition of Combined Supernates in Tank 241-AX-104 and Leakage Source Terms from the Fourth Quarter of 1972 to the Second Quarter of 1974

\begin{tabular}{|c|c|c|c|}
\hline $\begin{array}{c}\text { Component/ } \\
\text { Radionuclide }\end{array}$ & $\begin{array}{c}\text { Tank } 241-\mathrm{A}-104 \\
\text { Supernate Composition } \\
\mathrm{ug} / \mathrm{ml}(\mathrm{uCi} / \mathrm{ml})\end{array}$ & $\begin{array}{c}\text { Estimated Composition } \\
\text { of Tank } 241-\mathrm{AX}-104 \\
\text { Supernate }{ }^{\mathrm{b}}, \mathrm{ug} / \mathrm{ml} \\
(\mathrm{uCi} / \mathrm{ml}) \\
\end{array}$ & $\begin{array}{l}\text { Leakage Source } \\
\text { Terms for Tank } \\
\text { 241-AX-104 }, \mathrm{kg}(\mathrm{Ci})\end{array}$ \\
\hline $\mathrm{Al}$ & 163 & 170 & $5.1 \mathrm{~kg}$ \\
\hline $\mathrm{OH}$ & 8,160 & 7,589 & $229.2 \mathrm{~kg}$ \\
\hline $\mathrm{NO}_{3}$ & NR & $82,275^{\mathrm{d}}$ & $2,491 \mathrm{~kg}$ \\
\hline $\mathrm{NO}_{2}$ & $\mathrm{NR}$ & $40,665^{\mathrm{d}}$ & $1 ; 231 \mathrm{~kg}$ \\
\hline $\mathrm{Na}$ & 65,320 & 61,150 & $1,846.7 \mathrm{~kg}$ \\
\hline${ }^{90} \mathrm{Sr}$ & NR & $0.41 \mathrm{uCi} / \mathrm{ml}$ & $12.4 \mathrm{Ci}$ \\
\hline${ }^{134} \mathrm{Cs}$ & $0.26 \mathrm{uCi} / \mathrm{ml}$ & $0.24 \mathrm{uCi} / \mathrm{ml}$ & $7.3 \mathrm{Ci}$ \\
\hline${ }^{137} \mathrm{Cs}$ & $195 \mathrm{uCi} / \mathrm{ml}$ & $181 \mathrm{uCi} / \mathrm{ml}$ & $5,466 \quad \mathrm{Ci}$ \\
\hline 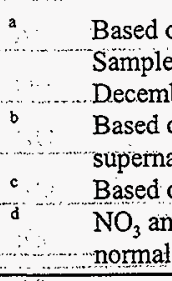 & $\begin{array}{l}\text { on letter from R.L. Walser } \\
\mathrm{T}-2893 \text {. Tank } 104-\mathrm{A} \text {, WH } \\
\text { ber } 31,1999 . . \\
\text { on } 93 \text { volume percent super } \\
\text { ate in equilibrium with Tan } \\
\text { on } 30.2 \mathrm{~kL} \text { ( } 8 \mathrm{kgal}) \text { of supe } \\
\text { id } \mathrm{NO}_{2} \text { based on } 60 \% / 40 \% \\
\text { ized to the moles of free } \mathrm{N}\end{array}$ & $\begin{array}{l}\text { R.E: Wheeler, 1974, Anal } \\
\text {-SD-WM-ER-308, radionu } \\
\text { ate from Tank 241-A-104 } \\
241-A X-104 \text { solids (Table } \\
\text { ate that might have leaked } \\
\text { lit found in Tank } 241-A X \\
\text { n the combined supernate, }\end{array}$ & $\begin{array}{l}\text { sis of Tank Farm } \\
\text { clides decayed to } \\
\text { ad } 7 \text { volume percent } \\
\text { 6) } \\
\text { during this period } \\
\text { 104 supernate }\end{array}$ \\
\hline
\end{tabular}




\title{
APPENDIX F \\ REPORT OF BEST-ESTIMATE PAST RELEASE \\ VADOSE ZONE CONTAMINATION \\ OF THE 241-AX TANK FARM
}

\author{
Provided by:
}

Columbia Energy \& Environmental Services, Inc.

1207 George Washington Way, Suite 12

Richlańd, WA:99352 


\section{CONTENTS}

1.0 CHEMICAL INFORMATION SOURCES $\ldots \ldots \ldots \ldots \ldots \ldots \ldots \ldots \ldots \ldots$ F-1

2.0 CONTAMINATION SITE SCREENING AND EVALUATION $\ldots \ldots \ldots \ldots \ldots \ldots$. . . .

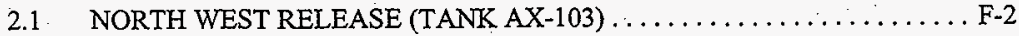

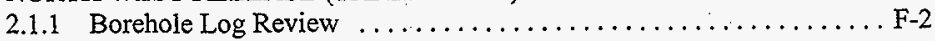

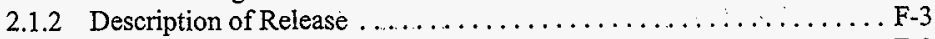

2.1.3 Interpretation of Material Released $\ldots \ldots \ldots \ldots \ldots \ldots \ldots \ldots \ldots \ldots$ F 3

2.2 NORTH CENTRAL RELEASE (TANKS 241-AX-103/241-AX-101) .... F-3

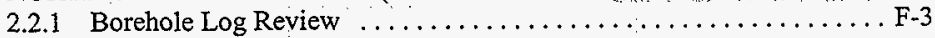

2.2.2 Description of Release $\ldots \ldots \ldots \ldots \ldots \ldots \ldots \ldots \ldots \ldots \ldots \ldots \ldots \ldots \ldots$

2.2.3 Interpretation of Material Relèased $\ldots \ldots \ldots \ldots \ldots \ldots \ldots \ldots \ldots$ F-4

2.3 CENTRAL NORTH WEST RELEASE (TANKS 241-AX-104/

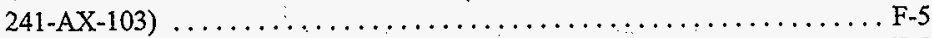

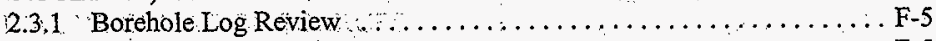

2.3.2 Description of Release $\ldots \ldots \ldots \ldots \ldots \ldots \ldots \ldots \ldots \ldots \ldots \ldots \ldots$ F-5

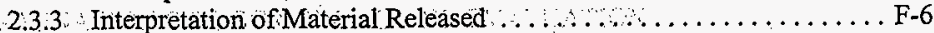

2.4 CENTRALRELEASE (TANK 241-AX-102/241-AX-101) . . . . . . . . F-7

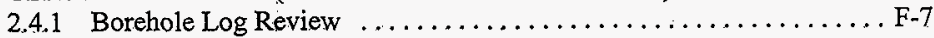

2.4 .2 Description of Release $\ldots \ldots \ldots \ldots \ldots \ldots \ldots \ldots \ldots \ldots \ldots \ldots \ldots$. $\ldots \ldots \ldots$

2.4.3 Interpretation of Material Released $\ldots \ldots \ldots \ldots \ldots \ldots \ldots \ldots \ldots \ldots$ F-8

2.5 CENTRAL AND SOUTH WEST(TANK AX-104) $\ldots \ldots \ldots \ldots$

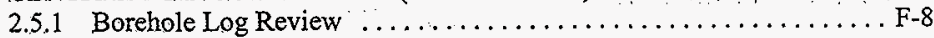

2.5.2 Description of Material Released . . . . . . . . . . . . . . F-9

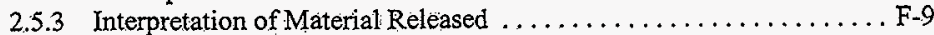

2.6 SOUTH EAST RELEASE (TANK 241-AX-102) . $\ldots \ldots \ldots \ldots \ldots \ldots$ F-9

2.6.1 . Borehole Log Review . . . . . . . . . . . . . . . . F-9

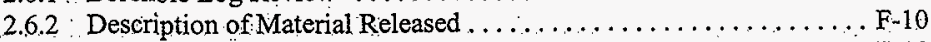

2.6.3 Interpretation of Material Released . . . . . . . . . . . . F F-10

2.7 GENERAL FARM CONTAMINATION $\ldots \ldots \ldots \ldots \ldots \ldots \ldots \ldots \ldots$ F-10

2.8 EX-FARM CONTAMINATION $\ldots \ldots \ldots \ldots \ldots \ldots \ldots \ldots \ldots \ldots \ldots \ldots \ldots$

3.0 CONTAMINANT STREAM COMPOSITIONS $\ldots \ldots \ldots \ldots \ldots \ldots \ldots \ldots \ldots \ldots$ F-12

4.0 RELEASE INVENTORY BEST ESTIMATE $\ldots \ldots \ldots \ldots \ldots \ldots \ldots \ldots \ldots \ldots \ldots$. $\ldots \ldots \ldots$

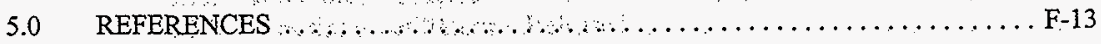

\section{FIGURES:}

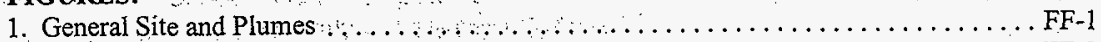

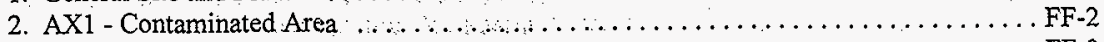

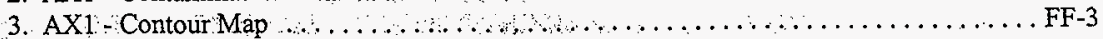

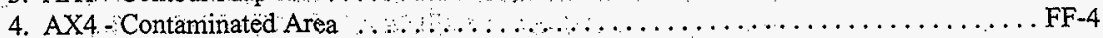

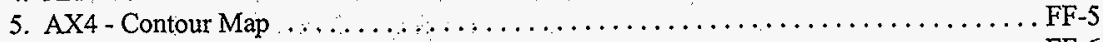

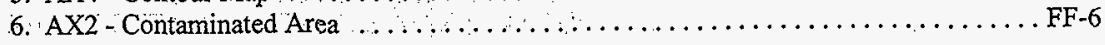


FIGURES (cont'd):

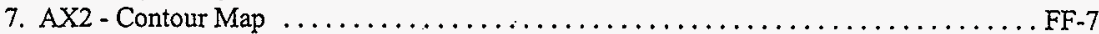

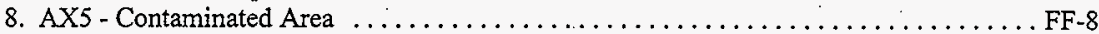

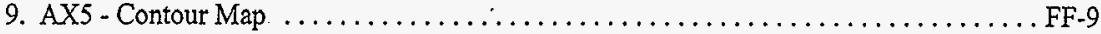

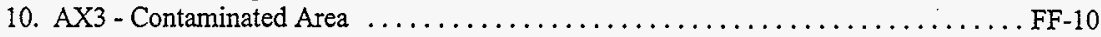

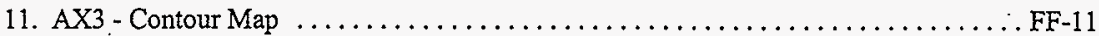

12. AX6 - Contaminated Area $\ldots \ldots \ldots \ldots \ldots \ldots \ldots \ldots \ldots \ldots \ldots \ldots \ldots \ldots \ldots \ldots \ldots \ldots \ldots \ldots \ldots \ldots, 12$

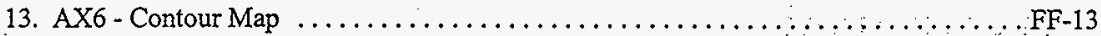

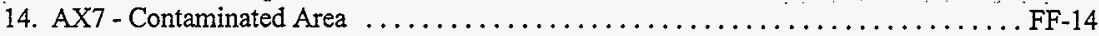

15. AX7 - Contour Map .................................

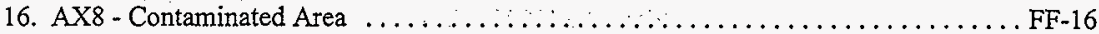

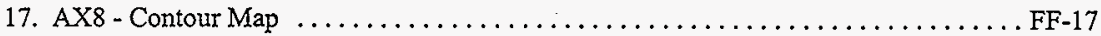

18. AX9 - Contaminated Area $\ldots \ldots \ldots \ldots \ldots \ldots \ldots \ldots \ldots \ldots \ldots \ldots \ldots \ldots \ldots \ldots \ldots \ldots \ldots \ldots \ldots, 18$

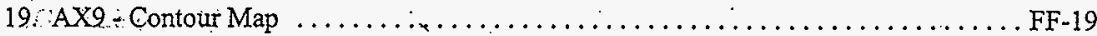

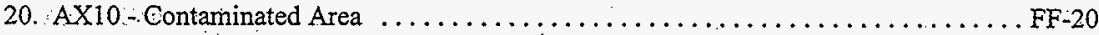

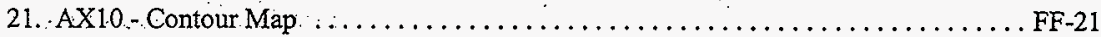

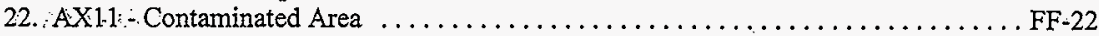

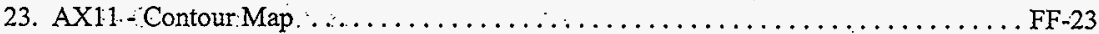

24. AX12 Contaminated Area $\ldots \ldots \ldots \ldots \ldots \ldots \ldots \ldots \ldots \ldots \ldots \ldots \ldots \ldots \ldots, \ldots \ldots \ldots, 24$

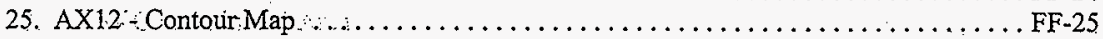

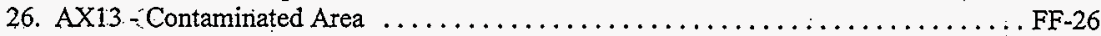

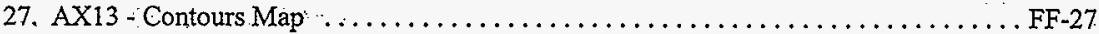

\section{TABLES:}

1. Summary of Contamination Releases $\ldots \ldots \ldots \ldots \ldots \ldots \ldots \ldots \ldots \ldots \ldots \ldots \ldots \ldots$ FT-1

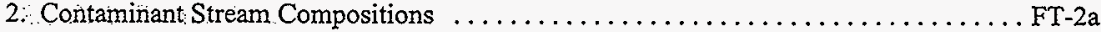

3. Contaminant Stream Radiological Compositions .................. FT-3a

4. 241 AX Farm Chemical Release Inventory Estimate $\ldots \ldots \ldots \ldots \ldots \ldots \ldots \ldots$ FT-4a

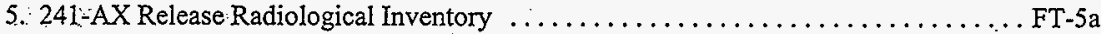

6. Estimated Volume of Contamination in 241 -AX Tank Farm . . . . . . . . . . . FT-6

7. Radioniuclide Concentrations of Zones of Contamination $\ldots \ldots \ldots \ldots \ldots \ldots \ldots$ FT-7

8. 241:AXTank Farm Release Radiological Inventory ...................... 
The purpose of this study is to provide a best-estimate of the chemical and radiological waste inventory which has been released to the vadose zone in and about the 241-AX Tank Farm. As part of this effort; an evaluation of available information for operations within the tank farm was performed including recent analyses of vadose zone gamma-emitting isotope contamination at thirty'two dry wells. A best-estimate based upon the source, time, nature, extent, and composition of the contaminant streams has been developed which employs the currently available data.

\subsection{CHEMICAL INFORMATION SOURCES}

Chemical and radionuclide inventory estimates are generally derived from one of two sources of information: (1) sample analysis (Brevick 1996) and sample derived inventory estimates, or (2) component compositions predicted by the Hanford Defined Waste model based upon process knowledge and historical tank transfer information (Agnew et al. 1997a). Due to the timing and nature of the evident releases, only one release can clearly be defined with analytical sampling (see Section 2:1 North West Release) while all other evident releases are defined by location, timing; and process history associated with specific Hanford Defined Waste Streams including OWW2, OWW3, IWW (P2), supernates and B Plant strontium recovery sludge.

\subsection{CONTAMINATION SITE SCREENING AND EVALUATION}

Recentanalyses of gamma-emitting isotopes contaminating the vadose zone of the 241-AX Tank Farm have yielded a preliminary report (DOE 1997a) providing indicators of the magnitude and location of contamination: within the tank farm. This preliminary report is based upon geophysical surveys conducted in dry wells located around the four tanks in the tank farm (DOE 1997b, 199.7c; 1997d; 1997e). Because the placement, and number, of boreholes are inherent limitations in this type of assay, these analyses can only provide indicators of contamination rather than a basis for a confirmed inventory assessment. The primary limitation is a lack of additional boreholes beyond the perimeter of the edge of the tanks and the maximum depths drilled. The outer edges of the zones of contamination are based on interpretation. A history of gross gamma energy readings in these dry wells provides a longer term view of the initiation and transport of the contamination plumes. These observed contamination sites, in conjunction with a review of facility processes, waste transfers; waste storage records, and occurrence reports, may adequately describe the nature and extent of contamination in the tank farmat a conceptual level.

In:review of the borehole logging and histories of releases, six primary release zones are associated with specific tanks and material compositions; these zones are diagrammatically rèpresented in Figüre 1: No available information could conclusively point to leakage from any of the four single-shell tanks within the farm; but much evidence was present to indicate that significant releases had occurred at and near the surface of the tank farm through transfer lines and tank ancillary equipment, particularly tank vent headers. Since there is no soil

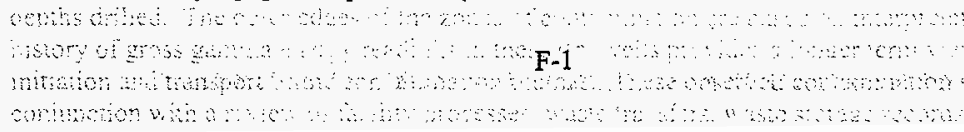


characterization data available, the chemistry and composition of the zones of contamination were used as indicators of migration to the depths indicated by the gamma-emitters measured in each dry well.

A critical parameter in defining the nature and extent of contamination occurring from past spills and leakage in the tank farms is the volume of the area affected. The shapes of the actual plumes in the soils in the 200 Areas are complex and depend on soil parameters such as the local depositional environment, porosity, vertical and horizontal hydraulic conductivities, as well as the characteristics of the spilled or leaked liquids. For the purpose of this study, it is assumed that the shapes of the saturated soil plumes can be approximated by cylinders and the shapes refined through interpretation. The plumes were assumed to have one of two source types. The first source type is a point source, where all leakage or spillage enters the soil from a single discrete point. The second, is a distributed source, in which leakage or spillage is assumed to enter the soil equally from several sources.

\subsection{NORTH WEST RELEASE (TANK AX-103)}

2,1.1 Borehole Log Review:

Review of existing:gamma logs for the north west edge of Tank 241-AX-103 suggests surface contamination in an area covered by boreholes $11-03-12$ and 11:03-10. This zone of contamination is identified as AX1 and is shown on Figures 2 and 3. This surface contamination may be related to a reported line failure in the $\mathrm{AX}-103$ pump pit. The assumption is that the $\mathrm{AX}-$ Q13 pump pit $03 \mathrm{~B}$ is the potential source of contamination.

From gamma borehole logs (DOE 1997d) data for two boreholes (11-03-12 and 11-03-10) located on the north west edge of Tank AX-103, indicate primary ${ }^{137} \mathrm{Cs}$ contamination to depths of approximately $6.1 \mathrm{~m}(20 \mathrm{ft})$. Minor ${ }^{137} \mathrm{Cs}$ is indicated to depths of approximately 18.3 to $21.3 \mathrm{~m}$ ( 60 to $70 \mathrm{ft})$. The presence of minor ${ }^{137} \mathrm{Cs}$ contamination to depths of approximately $21.3 \mathrm{~m} \cdot(70 \mathrm{ft})$ may be due to drilling practices introduced at the time the dry wells were drilled. The man-made radionuclides ${ }^{137} \mathrm{Cs},{ }^{60} \mathrm{Co}$, and ${ }^{125} \mathrm{Sb}$ were identified in the zone of contamination. The maximum concentration of ${ }^{137} \mathrm{Cs}$ was approximately $40 \mathrm{pCi} / \mathrm{g}$. No evidence was found to suggest the presence of a continuous plume associated with a tank leak. Examination and comparison of historical and present gamma logs indicate that following infiltration of the contaminants into the subsurface with subsequent migration to depths of approximately $18: 3 \mathrm{~m}$ $(60 \mathrm{ft})$, no further migration has occurred. The volume of the AX1 contamination is estimated to be approximately $5.34 \mathrm{E}+05 \ell\left(7.0 \mathrm{E}+02 \cdot \mathrm{yd}^{3}\right)$. The calculation of the volume of the zone for AX1 appears in Appendix A.

The backfill material emplaced around the tanks in the 241-AX Tank Farm extends from the base of the tanks to the surface, a depth of approximately $16.7 \mathrm{~m}(55 \mathrm{ft})$. Although the composition of the backfill material is predominantly pebbles, and coarse to medium sands with some silt, it is poorly sorted and only moderately permeable. The physical characteristics of this fill material are estimated to be 35 percent for soil porosity, 6 percent mojsture, and 20 percent void space (Routsonet al 1979). 


\subsubsection{Description of Release}

On February 12,1974 , while conducting a hydrostatic test on a line from the diversion box, the line failed in the AX-103 pump pit.

\subsubsection{Interpretation of Material Released}

Although the quantity of material released was not described, the composition was likely $\mathrm{AX}-103$ - supernatant liquor (PSS) diluted with water for hydrostatic testing. A volume estimate based on $30.5 \mathrm{~m}(100 \mathrm{ft})$ of $3.8-\mathrm{cm}(1.5$-in.) schedule 40 carbon steel pipe is approximately $40 \ell$ (10.6 gal) of PSS. The reports of Agnew and Brevick provide the bases for the volume estimate (Agnew et al. 1977b and Brevick 1996).

\subsection{NORTH CENTRAL RELEASE (TANKS 241-AX-103/241-AX-101)}

$\left\{\begin{array}{l}\mathrm{I} \\ \mathrm{y}\end{array}\right.$

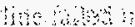

\subsubsection{Borehole Log Review}

Three boreholes (11-03-02, 11-01-10, and 11-01-11) located adjacent to the north central edge of tanks $\mathrm{AX}=103$ cand $\mathrm{AX}-101$ indicate primaryy ${ }^{137} \mathrm{Cs}$ contamination to depths of approximately 6.1 to $7.6 \mathrm{~m}$ (20.to $25 \mathrm{ft})$ : Minor ${ }^{137} \mathrm{Cs}$ contamination is indicated to depths of approximately $25.6 \mathrm{~m}$ (8.4 $\mathrm{ft}) \mathrm{I}$ Theprimary zone of contamination is depicted in Figures 4 and 5 and is identified as contaminâtion zone $\mathrm{AX} 4$. Thë man-máde radionuclides ${ }^{137} \mathrm{Cs},{ }^{60} \mathrm{Co},{ }^{154} \mathrm{Eu}$, and ${ }^{125} \mathrm{Sb}$ were identified in this zone of contamination. The maximum concentration of ${ }^{137} \mathrm{Cs}$ was: approximatelyi $4,000 \mathrm{pCi} / \mathrm{g}:$ Examination and comparison of historical gamma logs with present gamma logs indicate infiltration of the contaminants into the subsurface and subsequent migration to depths of approximately $25.6 \mathrm{~m} \mathrm{(} 84 \mathrm{ft}$ ); no further migration has occurred. The volume of the zone of contamination is estimated to be approximately $3.46 \mathrm{E}+06 \ell$

$\left(4.53 \mathrm{E}+03 \mathrm{yd}^{3}\right)$. The calculation of the volume of the zone for AX4 appears in Appendix A (DOE 1997b and DOE 1997d).

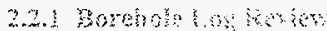

The:backfillmaterial emplaced around the tanks from the base to the surface; a depth of approximately $167 \mathrm{~m}$ ( $55 \mathrm{ft}$ ) consists predominantly of pebbles, and coarse to medium sands with some silt. This material is poorly sorted and considered moderately permeable. The physical properties of the backfill material have been described in Section 2.1.1.

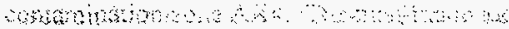
mastin

\section{2:22: Deseription of Release}

During valve change out on an $\mathrm{AX}-1.03$ recirculation line in 241-AX-801-B Instrument Building (some confusiont exists in the identification of which instrument building), the line pressurized withitank waste and spilled to floor of building. The waste volume was reported to be $20 \ell$ (5.3 gal) $\mathrm{A}: 0.5-\mathrm{m})(3-\mathrm{ft})$ deep trench was dug north out of the building to the north of the farm sưface $27.4 \mathrm{~m}(90 \mathrm{ft})$ over flat ground. A hole was cut in the building and a fire hose was used to wash waste into the trench. The presence of a significant zone of contamination north of Instrument Building $801 \mathrm{~A}$ suggests that $801 \mathrm{~A}$ was the source of the spill and not Instrument Building 801B. A second, parallel, trench was also cut and used for residual wash. Both trenches iwere backfilled with gravel (RHO 1990).

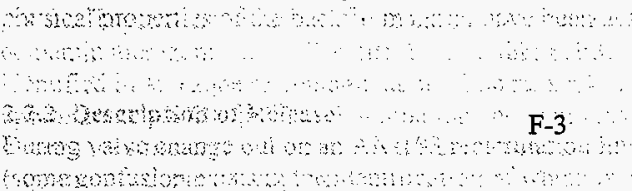


(forma17y known as)

Crib 216-A-39, which is located approximately $30.5 \mathrm{~m}$ (100 ft) north of Instrument Building $801 \mathrm{~A}$ is tied to an existing pipeline which may connect both Instrument Buildings $801 \mathrm{~A}$ and $801 \mathrm{~B}$, as determined from reference drawing $\mathrm{H}-2-33295$. The crib was constructed to receive the $20 \mathrm{l}(5.3 \mathrm{gal})$ of spilled waste from the $801 \mathrm{~A}$ Instrument Building. The crib is made up of four test wells which were constructed of 5 -cm (2-in.) schedule 40 perforated pipe. The test wells were completed in $61-\mathrm{cm}$ (24-in.) borings at depths of approximately $1.8 \mathrm{~m}(6 \mathrm{ft})$ and filled with $1.5 \mathrm{~m}$ ( $5 \mathrm{ft}$ ) of gravel, plastic sheeting, and backfill. The crib was active for one month, the month of June 1966, and received an unknown quantity of liquid including the $20 \ell(5.3 \mathrm{gal})$ of tank waste. The crib was closed in May 1973 and was covered with approximately $6.1 \mathrm{~m}(20 \mathrm{ft})$ of fill material.

As identified above, several inconsistencies exist with the cited report. The 241-AX-801-B Instrument Building is in the south center of the farm and services Tanks 241-AX-102 and 241- $\mathrm{AX}-104$. A trench dug north from this building would pass through the other instrument building. Drawing H-2-33295 shows the existence of a Crib 216-A-39 for use in collecting condensates from the 241-AX-801-B. Building. However, the details of drawing H-2-33295 indicate that a hand dug trench was provided to allow placement of a $10.1-\mathrm{cm}$ (4-in) schedule 40 pipe $15 \mathrm{~cm}$ (6:in) below grade running north, then north east (near the northwest quadrant of 241-AX 102) then north to the border of the farm where the line was reduced and welded into an existing $5.1-\mathrm{cm}(2$-in.) schedule 40 pipe which travels north outside of the farm to two parallel ends $18.3 \mathrm{~m}(60 \mathrm{ft})$ and $39.6 \mathrm{~m}$ (130 ft) north of the farm boundary; thereby defining Crib 216-A-39. Coating instructions and drain instructions on the drawing are consistent with expectations of future 801-B floor contamination in the way that one might expect from a lesson learned from prior spills at 801A.

One abandoned and capped dry well (11-02-08) and seven poorly documented PVC wells (E25:1377 through E25-144) in the south central part of the farm (SW quadrant of 241-AX-102) may be indicative of a spill investigation on the southeast comer of $241-\mathrm{AX}-801-\mathrm{B}$, but no reports are available that suggest that a spill occurred in this region. Further investigation into the site history revealed that the area was part of a short-term research project conducted to determine alternative leak detection technologies. The project was unsuccessful and no further data or history could be located.

\section{2:2.3 Interpretation of Material Released}

The spill into the soil in the AX4 zone of the farm was direct tank supernatant liquor from Tank $241: A X-103$ (RHO 1990). No chemical fixatives were used in decontamination. The immediate decontamination solution, a large volume of water, percolated fairly rapidly into the soil as the Waste-liquor was sluiced into the trench. The non-saturated trench saw the highest concentration material first which resulted in the placement of primary contamination at the entrance of the first trench $:$ Reported activity appears below.

\begin{tabular}{|l|l|l|}
\hline $\begin{array}{c}\text { Radionuclide/Source } \\
\text { At time of Discharge } \\
\text { (Ci) }\end{array}$ & $\begin{array}{c}\text { As of June 30, 1978 } \\
\text { (Ci) }\end{array}$ \\
\hline Beta & 50 & 36.4 \\
\hline Gs & 25 & 190 \\
\hline
\end{tabular}


(formally known as)

This cesium-based calculation places the discharge date approximately $11.95 \mathrm{yr}$ prior to measurement, in the June or July 1966 time frame $(t=-\ln (\mathrm{A} 1 / \mathrm{A} 0) / \lambda)$. The crib service date is noted to be June 1966. The drawing H-2-33295 was first drawn in September 1966. This time period reflects the early operation of Tank 241-AX-103 when neutralized PUREX waste was being received. This composition is consistent with description of the waste as 'low-salt, neutral/basic'. PUREX wastes received into AX-103 by June 1966 include $6.12 \mathrm{E}+06 \ell$ $(1.62 \mathrm{E}+06 \mathrm{gal}) \mathrm{IWW}$ and $5.87 \mathrm{E}+06 \ell(1.55 \mathrm{E}+06 \mathrm{gal}) \mathrm{OWW}$ for a total of $1.20 \mathrm{E}+07 \ell(3.17 \mathrm{E}+06$ gal) with a net of $3.77 \mathrm{E}+06 \ell(9.96 \mathrm{E}+05 \mathrm{gal})$ in storage at the end of second quarter 1966 .

The material to be described for this release would indicate that the beta source calculated in the report was assumed to be ${ }^{90} \mathrm{Sr}$. Another informal report, East Tank Farms History (Kelly 1994); places the event during June 1966. As analyzed below from the material composition, the ${ }^{137} \mathrm{Cs}$ contamination from $20 \mathrm{\ell}(5.3 \mathrm{gal})$ as reported would be estimated to be $5.6 \mathrm{Ci}$ at December $31 ; 1999$ while: the decay from the reported activity would yield $11: 33 \mathrm{Ci}$ - In correcting for this estimate, this spill is interpreted and applied as $40 \mathrm{\ell}(10.6 \mathrm{gal})$. The beta energy, potentially associated with ${ }^{90} \mathrm{Sr}_{\text {; }}$ cannot be clearly associated with this waste stream. It is believed that even though the beta sources initially reported include a broad range of short-lived materials the half life of strontium was applied in the spill estimate report:

mutribure (1) $63-60$

\section{2:3 CENTRAL NORTH WEST RELEASE (TANKS 241-AX-104/241-AX-103)}

\section{2:31. Borehole Log Review}

Four:boreholes (11-04-01,11-04-11, and 11-03-07,11-04-10) located north:west of Tank $241 \mathrm{AX}$.04 indicate primary ${ }^{137} \mathrm{Cs}$ contamination is present to depths ranging from approximately 3 to $6 \mathrm{~m}(10$ to $20 \mathrm{ft}) . \mathrm{Minor}{ }^{137} \mathrm{Cs}$ contamination is indicated to depths of appoximately $12 \mathrm{~m}$. $(40 \mathrm{ft}$ ) The primary zone of contamination is located on Figures 6 and 7 and is identified as contamination zone $\mathrm{AX} 2$. The man-made radionuclides ${ }^{137}, \mathrm{Cs}$, ${ }^{60} \mathrm{Co}$, and ${ }^{154} \mathrm{Eu}$ were identified in this zone of contamination. The maximum concentration of ${ }^{137} \mathrm{Cs}$ was approximately $100 \mathrm{pCi} / \mathrm{g}$. Examination and comparison of historical gamma logs with present gamma logs indicates that upon following infiltration of the contaminants into the subsurface with subsequent migration to depths of approximately $12 \mathrm{~m} \mathrm{(40} \mathrm{ft),} \mathrm{no} \mathrm{further} \mathrm{migration} \mathrm{has}$ occurred The volume of the zone of contamination is estimated to be approximately $1.22 \mathrm{E}+06 \ell$ $\left(1.60 \mathrm{E}+03 \mathrm{yd}^{3}\right)$. The calculation of the volume of the zone for $\mathrm{AX} 2$ appears in Appendix $\mathrm{A}$ (DOE 1997d and:DOE 1997e).

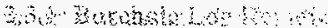

The backfill material emplaced around the tanks in the 241-AX Tank Farm extends from the base of: the tanks to the surface; a depth of approximately $16.7 \mathrm{~m}$ (55 ft). Although this backfill material consists predominantly of pebbles, and coarse to medium sands with some silt, it is poorly sorted and only moderately permeable. The physical properties of the backfill material have been described in Section 2:1:1.

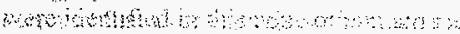

thutwis

\subsubsection{Description of Release}

On January 30,1968; while an attempt was underway to unplug a transfer line from Tank 24: $\mathrm{AX}-102$ with high water pressure, a leak in the ground was observed adjacent to Tank 
241-AX-103. The hot dirt was hauled off and plastic was placed over remaining hot dirt and transfer line in the excavation.

Some inconsistencies in information exist on this spill. Transfer lines from 241-AX-102 are not common to $241-\mathrm{AX}-103$, as they must go through a minimum of one valve pit (241-AX-B). Water supply could come in, but could not be hooked up at the same time as a transfer from 241-AX-102 to 241-AX-103. It is apparent that the author of the release description merely wanted to say that transfer line was plugged by transfer from $\mathrm{AX}-102$ to $\mathrm{AX}-103$ and that remediation was high pressure flush. The WSTRS (Agnew et al. 1997b) does not indicate any transfer from 241-AX-102 to 241-AX-103 during the first quarter of 1968.

Leak detection pit for 104-AX began increasing in activity in late 1976, with counts peaking in December 1978. Sluice pit transfers had occurred prior to 1976 , and primary stabilization of the pit took place in September 1978: Liquid level was reduced in August 1977. to $18 \mathrm{~cm}$ (7.1 in.), but sluicing and transfers continued through April 1978.

Well: $11-04-11$, in close proximity to the 241-AX-103/241-AX-104 vent header, demonstrated primary cesium contamination at $7.6 \mathrm{~m}(25 \mathrm{ft})$ and again at $18 \mathrm{~m}(59 \mathrm{ft})$. when first monitored in January 1975. The contamination plume increased in depth and decreased in concentration until 1982 when readings fell below background. It appears that the initial at-depth contamination may have been associated with the drilling operation. Welty (1991) notes that investigation determined the sources of contamination to be 241-AX-104's 51-cm (20-in) vapor line at points both above the tank and at the line tied:into the $61-\mathrm{cm}$ (24-in.) vessel vent header.

Drywell 11-04-01, when first monitored in January 1975 indicated high subsurface counts at a depth of about $7.3 \mathrm{~m}(24 \mathrm{ft})$. This plume decreased and proceeded to a depth of about $11.3 \mathrm{~m}$ $(37 \mathrm{ft})$ before decreasing below background in 1982 . This activity is adjacent to the $241-\mathrm{AX}-103 / 241-\mathrm{AX}-104$ yent header in highly permeable soils.

No interpretation is available for the first two contamination zones above; however, the latter: contamination zones are ascribed to the $241-\mathrm{AX}-103 / 241-\mathrm{AX}-104$ vent header leakage and potential tränsfer line leakage which has been estimated at $3.03 \mathrm{E}+04 \ell(8.0 \mathrm{E}+04 \mathrm{gal})$ at the deelaration as a leaker. Although the releases in the regions of the first two contamination zones described here are important for personnel protection, they are deemed to be much smaller than the aggregate of the latter releases. The source composition, would appear to be defined by the boiling history (Mercier 199.0) and air lift circulator (ALC) operation which significantly indicated long-term boiling through early 1970 ; the primary solutions present in the tank at this time were PUREXIWW (P.2) waste with trace B-Plant solutions. The material appears to have been aerosolized after which it collected in the vent header and then leaked to the soil.

\subsubsection{Interpretation of Material Released}

The spill was a subsurface line spill of 241-AX-102 tank liquor and solids. Time period would indicate that material lost was neutralized PUREX wastes (high level P2 and OWW2) present in the tank at the end of 1967. A 6.96E+05 l (1.84E+05 gal) water heel was present mid-year 1966, with receipt of $2: 41 \mathrm{E}+06 \ell(6.36 \mathrm{E}+05 \mathrm{gal}) \mathrm{OWW}$ waste through 1966 , receipt of an additional $3.29 \mathrm{E}+05 \%(8.7 \mathrm{E}+04 \mathrm{gal}) \mathrm{OWW}$ and shipment of essentially all contents removed by end of third quarter 1967 ; and refilled with $\mathrm{OWW}$ waste in fourth quarter to $2.25 \mathrm{E}+06$ \& (5.94E+05 gal). 
Next receipts in early 1967 were OWW (Anderson 1990). These reports are not inconsistent with WSTRS (Agnew et al. 1997b) which indicates OWW (P) static in the tank having been received as supernate following sludge deposition in Tank 241-AX-101.

The inventory of material released is unkinown. The source is probably $241-\mathrm{AX}-102$ supernate from late 1967 to January 1968 with some sludge entrainment of OWW2 waste. The locus of release to soil column is not defined, but likely to be near the south center of 241-AX-103 dome edge. An estimate of material release based upon $61 \mathrm{~m}$ (200 ft) of 3.8-cm (1.5-in.) schedule 40 carbon steel piping is $80 \ell$ ( $21.1 \mathrm{gal})$ of OWW2 waste.

\subsection{CENTRAL RELEASE (TANK 241-AX-102/241-AX-101)}

\subsubsection{Börehole Log Review}

Four boreholes (11-02-11,11-02-12,11-02-22, and 11-01-05) located on the north west edge of Tank $241-\mathrm{AX}-102$ indicate primary ${ }^{137} \mathrm{Cs}$ contamination depths of approximately 3 to $4.6 \mathrm{~m}$ (1.0 to $15 \mathrm{ft})$. Minor ${ }^{137}$. Cs contamination is indicated to depths of approximately $12 \mathrm{~m}(40 \mathrm{ft})$. This zone of contamination is identified as AX5 and is shown on Figures 8 and 9. Cesium-137, ${ }^{60} \mathrm{Co},{ }^{154} \mathrm{Eu}$, and ${ }^{125} \mathrm{Sb}$ were the man-made radionuclides identified in this zone contamination: The maximum concentration of ${ }^{137} \mathrm{Cs}$ was approximately $417.8 \mathrm{pCi} / \mathrm{g}$. Examination and comparison of historical gamma logs with present gamma logs indicate that following infiltration of the contaminants into the subsurface with subsequent migration to depths of approximately $12 \mathrm{~m}(40 \mathrm{ft}$ ), no further migration occurred. The volume of the zone of contamination is estimated to be approximately $1.10 \mathrm{E}+06 \ell\left(1.44 \mathrm{E}+03 \mathrm{yd}^{3}\right)$. The calculation of the volume of the zone for AX5 is included in Appendix A (DOE $1997 \mathrm{~b}$ and DOE 1997c).

The backfill material emplaced around the tanks in the 241-AX Tank Farm extends from the base of the tanks: to the surface, a depth of approximately $16.8 \mathrm{~m}(55 \mathrm{ft})$. This material consists of predominantly of pebbles, and coarse to medium sands with some silt. This backfill is poorly sorted and considered moderately permeable: The physical properties of the backfill material have been desscribed in Section 2:1:1:

\subsubsection{Description of Release}

Wells 1:1:02:11 and 11-02-12 demonstrated primary contamination at depths of approximately $17.1 \mathrm{~m}(56 \mathrm{ft})$ and $12.2 \mathrm{~m}(40 \mathrm{ft})$, respectivelÿ, upon first monitoring in May and June 1975 (Welty 1991) : Little migration was seen with activity dropping off to background levels by 1986 and 1984, respectively. Current logging indicates no significant contamination at-depth but significant contamination near surface, almost entirely within the top $4.6 \mathrm{~m}(15 \mathrm{ft})$ of soil.

The contamination source has been previously interpreted to be vent header leak. In late 1975 an asphalt sealant wàs:injected into the soil to contain the activity and seal the dresser coupling leak.

Well 11 $01-05$ activity began increasing in June 1976 at a depth of approximately $21 \mathrm{~m} .(70 \mathrm{ft})$ and remained at that depth before falling below background in November 1984. This was considered to be the continued migration of vapor header leakage from 241-AX-101/241-AX-

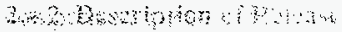


102. Current well logging continues to display primary contamination within the top $1.5 \mathrm{~m}(5 \mathrm{ft})$ of soil.

\subsubsection{Interpretation of Material Released}

Quantity of the release associated with wells 11-02-11 and 11-02-12 is unknown. The composition of the released material is likely $241-\mathrm{AX}-102$ supernatant liquor released prior to 1976. Given the history of boiling (Mercier 1990), application of air lift circulators (ALC), and probability of association with vapor header, the time frame for release is most likely prior to 1969. The material was probably PUREX OWW3 which had been aerosolized and carried into ventilation system after which it leaked into the soil. It is expected that this is the same release that was seen at well 11-01-05, discussed below.

This release was observed to have occurred in the region of the vent header associated with 241AX -102 (Welty 1991).

Although the quantity for the released material associated with well 11-01-05 is unknown, the composition is likely $241-\mathrm{AX}-102$ supernatant liquor released prior to 1976 . Given the history of boiling (Mercier 1990); application of ALC, and probability of association with the vapor header, the time frame for the release is most likely prior to 1969. The material was probably PUREX OWW 3:which had been aerosolized and carried into ventilation system after which it leaked into the soil An estimate had been previously established as $1.14 \mathrm{E}+04.0$ ( $3.0 \mathrm{E}+0.3 \mathrm{gal})$ in defining the tank as aleaker. The contamination is reasonably well associated with that described above.

\subsection{CENTRAL AND SOUTH WEST (TANK AX-104)}

Releases in this sector are ascribed to both identifiable and unidentifiable sources. The largest of the sources is associated with possible transfers and decontamination activities at the sluice pits.

\subsection{Borehole Log Review}

Three boreholes (11-04-07, 11-04-08, and 11-04-19) located on the south west edge of Tank 241$\mathrm{AX}-104$ indicated primary ${ }^{137} \mathrm{Cs}$ contamination depths of approximately $1.5 \mathrm{~m}(5 \mathrm{ft})$. Minor ${ }^{137} \mathrm{Cs}$ contamination is indicated to depths of approximately $21 \mathrm{~m}(70 \mathrm{ft})$ This zone of contamination is identified as: $\mathrm{AX} 3$ and is shown on Figures, 10 and 11 . The only man-made radionuclide detected in the zone of contamination was ${ }^{137} \mathrm{Cs}$ with a maximum concentration of approximately $34 \mathrm{pCi} / \mathrm{g}$. Examination and comparison of historical gamma logs with present gamma logs indicate that following infiltration of the contaminants into the subsurface with subsequent migration to depths of approximately $21 \mathrm{~m}(70 \mathrm{ft})$, no further migration has occurred. The volume of the zone of contamination is estimated to be approximately $8.02 \mathrm{E}+05 \ell$ $\left(1.05 \mathrm{E}+03 \mathrm{yd}^{3}\right)$ : The calculation of the volume of the zone for $\mathrm{AX} 3$ is included in Appendix $\mathrm{A}$ (DOE 1997e).

The backfill material emplaced around the tanks in the 241-AX Tank Farm extends from the base of the tanks to the surface, a depth of approximately $16.8 \mathrm{~m}$ (55 ft). Although the backfill material consists predominantly of pebbles, and coarse to medium sands with some silt, it is 
poorly sorted and only moderately permeable. The physical properties of the backfill material have been described in Section 2.1.1.

Some inconsistencies exist with borehole locations. Borehole 11-04-07, identified as located near the 241-AX-B Valve Pit, is incorrectly located and should be near 11-04-19 which would place it $30.5 \mathrm{~m} .(100 \mathrm{ft})$ closer to the tank.

\subsubsection{Description of Material Released}

In November 1977, drywell 11-04-08 showed increasing activity at 19.5-m (64-ft) level; it had begun exceeding background in August 1976. By 1984, the counts had dropped to background. Current gamma logging indicates near surface contamination of depths of about $16.5 \mathrm{~m}(54 \mathrm{ft})$ (tank bottom) in the region of valve pit 241-AX-A. As a comparison, well 11-04-07 indicates only surface contamination close to the valve pits.

The leak detection pit for 241-AX-104 began increasing in activity in late 1976 with peaking in December 1978: Sluice pit transfers had occurred prior to 1976 ; and primary stabilization of the pit took place in September 1978. Liquid level was reduced in August 1977-to 7.1 inc; but sluicing and transfers were:occurring through April 1978.

Well 11-04-19 indicates potential contamination in the southwest quadrant to an approximate depth of $21 \mathrm{rm}$ m (70 ft). This well is close to the 241-AX-04B sluice pit and transfer lines. The history of transfer line leaks in the-farm lends credence to the belief that contamination in this: zone:is due to leaking transfer lines.

\section{2:5:3 Interpretation of Material Released}

No intexpretation is available for the contamination zone described above; however, transfer line leakages are probable sources of this contamination. The source composition would appear to be greatly defined by the boiling history:(Mercier 1990), and ALC operation which significantly:... indicates long term boiling through early: 1970, and the primary solutions present in the tank: which wereiREREXIWW(P2) waste with trace B:Plant solutions.

\subsection{SOUTH EAST RELEASE (TANK 241-AX-102)}

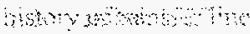

\subsubsection{Borehole Log Review}

Five boreholes (11-02-01, 11-02-02, 11-02-03, 1-02-04, and 11-02-05) located on the north east edge of Tank $241<\mathrm{AX}-102$ indicate primary ${ }^{137} \mathrm{Cs}$ contamination occurring at the surface and at depthis of $1: 5$ to $4.6 \mathrm{~m}$ ( 5 to $15 \mathrm{ft}$ ). A general trend downward of primary ${ }^{137} \mathrm{Cs}$ contamination continues:to depths of approximately $22.9 \mathrm{~m}(75 \mathrm{ft})$. This apparent plume of contamination is evident in the borehole logs: $(11-02-01,11-02-02$, and 11-02-03) and decreases in activity at depthithis zone of:contamination is identified as AX6 and is shown on Figures 12 and 13 . The man made radionuclides ${ }^{137} \mathrm{Cs}$ and ${ }^{60} \mathrm{Co}$ were: identified in the zone of contamination with ${ }^{137} \mathrm{Cs}$ having a maximum concentration of approximately $15.8 \mathrm{pCi} / \mathrm{g}$. Examination and comparison of historical gamma logs. with present gamma logs indicate that following infiltration of the contaminants into the subsurface with subsequent migration to depths of approximately $22.9 \mathrm{~m}$ 
(formally known as)

$(75 \mathrm{ft})$, no further migration has occurred. The volume of the zone of contamination is estimated to be approximately $3.36 \mathrm{E}+06 \ell\left(4.4 \mathrm{E}+03 \mathrm{yd}^{3}\right)$. The calculation of the volume of the zone for AX6 is included in Appendix A (DOE 1997c).

The backfill material emplaced around the tanks in the 241-AX Tank Farm extends from the base of the tanks to the surface, a depth of approximately $16.8 \mathrm{~m}(55 \mathrm{ft})$. This material consists predominantly of pebbles, and coarse to medium sands with some silt This backfill is poorly sorted and considered moderately permeable. The physical properties of the backfill material have been described in Section 2.1.1.

\subsubsection{Description of Material Released}

On December 3,1976, during a jumper removal in the AX-102-02A pump pit a dark solution ran from an open nozzle to the pit floor. High dose readings led an operator to flush the released material off the floor. The high temperature of the pit and solution resulted in spray and vapor being released out of pit in a plume for about $22.9 \mathrm{~m}(75 \mathrm{ft})$, in a southerly direction.

Decontamination efforts were not described (Kelly 1994).

\section{2:6.3 Interpretation of Material Released}

The spill into the soil was an aerosol of tank supernatant liquor (primarily water) and solids from, presumably, 241-AX-102. B-Plant strontium recovery activities for this tank were underway and nearly complete during this period. The volume of the spill was undefined but not likely to be less than $1 \mathrm{l}(0.26 \mathrm{gal})$ nor greater than $100 \ell(26.4 \mathrm{gal})$. It is reasonable to believe that the aerosolized portion did not exceed 50 percent of solution spilled in pit. An estimate of $20 \ell$ ( $5.3 \mathrm{gal}$ ) contaminated liquid with 10 percent sludge is considered reasonable. Decontamination efforts likely included water washdown of large surface areas over the tank dome. This would have driven the contamination plume to the dome upper surface and over the edge of dome.

\subsection{GENERAL FARM CONTAMINATION}

Numerous reports exist of accidental surface contamination, usually associated with sludge measurement systems, sluicing operations, and tank waste transfers Additionally, the gamma borehole logging (DOE 1997a) indicates general contamination spread throughout the near-surface region of the tank farm. It is believed that the majority of this general contamination is due to transport from the described releases at or near the surface of the tank farm These minor releases have been assigned zones of contamination AX7, AX8, AX9, AX10, $\mathrm{AX} 11, \mathrm{AX} 12$, and $\mathrm{AX} 13$. The locations of these zones of contamination are shown on Figure 1. Limited documentation is available to determine the compositions and inventory of these minor zones of contamination.

The zone of contamination designated as AX7 is shown on Figures 14 and 15. AX7 is located on the west central side of Tank $241-\mathrm{AX}-103$. The zone of contamination extends to an approximate depth of $3.7 \mathrm{~m}(12 \mathrm{ft})$ with the only man-made radionuclide detected being ${ }^{137} \mathrm{Cs}$. The maximum concentration of ${ }^{137} \mathrm{Cs}$ was $7.5 \mathrm{pCi} / \mathrm{g}$ at $0.46 \mathrm{~m}(1.5 \mathrm{ft})$. The volume of the zone of contamination is estimated to be approximately $2.17 \mathrm{E}+05 \mathrm{l}\left(2.84 \mathrm{E}+02 \mathrm{yd}^{3}\right)$. The calculation of the volume of the zone for AX7 is included in Appendix A. 
(formal ly known as)

The zone of contamination designated as AX8 is shown on Figures 16 and 17. AX8 is located on the northwest edge of Tank AX-104 and may be co-mingled with the AX2 zone of

contamination. This zone of contamination extends to an approximate depth of $12.2 \mathrm{~m}$ (40 ft). The man-made radionuclides ${ }^{137} \mathrm{Cs},{ }^{60} \mathrm{Co}$, and ${ }^{154} \mathrm{Eu}$ were detected in the zone of contamination. The maximum ${ }^{137} \mathrm{Cs}$ concentration was approximately $1,456 \mathrm{pCi} / \mathrm{g}$ at $1.1 \mathrm{~m}(3.5 \mathrm{ft})$. The volume of the zone of contamination is estimated to be approximately $6.79 \mathrm{E}+05 \ell\left(8.88 \mathrm{E}+02 \mathrm{yd}^{3}\right)$. The calculation of the volume of the zone for AX8 is included in Appendix A.

The zone of contamination designated as AX9 is shown on Figures 18 and 19. AX9 is located on the northeast edge of Tank 241-AX-101. This zone of contamination extends to an approximate depth of $6.1 \mathrm{~m}(20 \mathrm{ft})$. The man-made radionuclide detected was identified.as ${ }^{137} \mathrm{Cs}$. The maximum concentration was approximately $8 \mathrm{pCi} / \mathrm{g}$ at 0.6 and $5.5 \mathrm{~m}(2$ and $18 \mathrm{ft})$. The volume of the zone of contamination is estimated to be approximately $2.57 \mathrm{E}+05 \ell\left(3.36 \mathrm{E}+02 \mathrm{yd}^{3}\right)$. The calculation of the volume of the zone for AX9 is included in Appendix A.

The zone of contamination designated as AX10 is shown on Figures 20 and:21. AX10 is located on the easterri edge of Tank $241-\mathrm{AX}-101$. The zone of contamination extends to an approximate dèpth of $3 \mathrm{~m}$ ( $\left(10^{\circ} \mathrm{ft}\right)$ : The man-made radionuclide ${ }^{137} \mathrm{Cs}$ was identified in this zone of: contamination. The maximum concentration of ${ }^{137} \mathrm{Cs}$ was approximately $6 \mathrm{pCi} / \mathrm{g}$.- The volume of the zone of contamination is estimated to be approximately $1.22 \mathrm{E}+05 \ell\left(1.59 \mathrm{E}+02 \mathrm{yd}^{3}\right)$. The calculation of the volume of the zone for AX10 is included in Appendix A.

The zone of contamination designated as AX11 is shown on Figures 22 and 23. AX11 is located on the southeastern edge of Tank 241-AX-101.: The zone of contamination extends to an approximate depth of $7: 6 \mathrm{~m}(25 \mathrm{ft})$. The man-made radionuclide ${ }^{137} \mathrm{Cs}$ was identified in this zone of contamination. The maximum concentration of ${ }^{137} \mathrm{Cs}$ was approximately $51.5 \mathrm{pCi} / \mathrm{g}$. The estimated volume of contamination is approximately $2.11 \mathrm{E}+0 . \mathrm{l}:\left(2.75 \mathrm{E}+02 \mathrm{yd}^{3}\right)$. The calculation of the volume of the zone for AX11 is included in Appendix A.

The zone of contamination designated as $\mathrm{AX} 12$ is shown on Figures 24 and 25: AX12 is located on the south west edge of Tank 241-AX-102. The zone of contamination extends to an approximatedepth of $6: 1 \mathrm{~m}(20 \mathrm{ft})$. The man-made radionuclide identified in the zone of contamination is $137 \mathrm{Es}$ with an approximate concentration of $13 \mathrm{pCi} / \mathrm{g}$. The volume of contamination is estimated to be approximately $2.2 \mathrm{E}+05 \ell\left(2.88 \mathrm{E}+02 \mathrm{yd}^{3}\right)$. The calculation of the volume of the zone for AX12 is included in Appendix A.

The zone of contamination designated as AX13 is shown on Figures 26 and 27. AX13 is located on the south east edge of Tank 241-AX-104. The zone of contamination extends to an approximate depth of $6.1 \mathrm{~m}$ (20 ft). The man-made radionuclide identified in this zone of contamination is $137 \mathrm{Cs}$ with a maximum concentration of approximately $9.8 \mathrm{pCi} / \mathrm{g}$. The volume of contamination is estimated to be approximately $2.43 \mathrm{E}+05 \ell\left(3: 18 \mathrm{E}+02 \mathrm{yd}^{3}\right)$. The calculation of the volume of the zone for AX13 is included in Appendix A.

\section{2:8 EXFARM CONTAMINATION}

\section{Sumprman}

At present, no compelling evidence exists that contamination near the tank farm has resulted in plume migration into the 241-AX Tank Farm: As described above, some areas of existing 
contamination near the surface and adjacent to the tanks has likely been due to transfer line leaks. The volumes and inventory of these leaks in ancillary equipment have been aggregated into the leakage declaration volumes $\mathrm{AX}-102$ and $\mathrm{AX}-104$. The nearest potential zone of contamination is one associated with the 216-A-39 Crib which operated for approximately one month. There was no soil characterization data available for this site.

\subsection{CONTAMINANT STREAM COMPOSITIONS}

As described above, a summary of contaminant streams is tabulated in Table 1 with compositions described in Tables 2 and 3 Chemical Contaminants and Radiological Contaminants, respectively. Contaminant stream compositions are based upon reports by Agnew and Brevick as described in Section 1.0.(Agnew 1997a and Brevick 1996).

No laboratory data on these streams is available which describes useful information on the waste contaminants. Among these characteristics is that of the valence of chromium as +6 . From a process perspective, a release into the soil may reduce the valence to +3 , and the PUREX stream sources were neutralized prior to shipment to this farm. From this standpoint, the $\mathrm{Cr}^{+6}$ fraction should be less than 5 percent of total chromium in the stream.

\subsection{RELEASE INVENTORY BEST ESTIMATE}

An estimate of release inventory has been prepared based on the composition of identified waste streams deemed released in the six major contamination zones of the AX-241 Tank Farm. These have been tabulated, grouping the zones into six areas, by chemical and radiological contaminants in Tables 4 and 5 , respectively. The extent of contamination identified in the vadose zone at 241-AX Tank Farm was based on the results of geophysical well logging studies. The gross gamma-ray logs produced during these studies were evaluated for the radionuclide migration from post spills in the vadose zone. The primary radionuclides monitored were ${ }^{137} \mathrm{Cs}$, ${ }^{60} \mathrm{Co}$, ${ }^{154} \mathrm{Eu}$, and ${ }^{125} \mathrm{Sb}$. Table 6 is a summary of the estimated volumes of contamination for each zone identified. The relationship between ${ }^{137} \mathrm{Cs}$ and the other more highly mobile radionuclides and chemical contaminates has not yet been established. Consequently, there is no direct way to assess the potential extent of migration from the releases around the 241-AX Tank Farm.

Several reports were reviewed which suggest that distribution of mobile contaminates under a number of conditions could be extensive. In order to estimate the potential extent of contamination resulting migration of the more mobile constituents, the initial volume estimates were doubled, as seen in Table 6.

As tabulated, the majority of identified contaminants of concern to site closure activities are those of beta and gamma radiation, due to cesium and strontium contamination in the north central region. The central southwest region is second and is associated. with the 241-AX103/241-AX-104 vent header. The third highest area of contamination is in the central east 
portion of the farm associated with the 241-AX-101/241-AX-102 vent header. Table 7 is a summary of the concentration for each zone-and the man-made radionuclides identified.

As described by process history and by historic and current borehole logging of gamma contamination in the farm, there is no conclusive evidence of leakage from the tank structures. However, extensive evidence exists of losses from the vent headers, valve pits, risers, and possibly transfer lines. The maximum depth of migration for the zones of contamination described above is approximately $30.5 \mathrm{~m}$ (100 ft). The maximum concentration of man-made radionuclides measured in the tanks farm soils is approximately $4,000 \mathrm{pCi} / \mathrm{g}$. Examination and comparison of historical and present gamma logs indicate that following initial infiltration of the contaminants with subsequent migration to the indicated depths, no evidence of further migration is indicated.

An evaluation was performed on the radiological release-inventory presented in Table 5 to determine which transuranics. were released and their total estimated concentrations. The primary transuranics presented in the releases are ${ }^{237} \mathrm{Pu},{ }^{237} \mathrm{~Np},{ }^{240} \mathrm{Pu},{ }^{241} \mathrm{Am},{ }^{242} \mathrm{mAm},{ }^{243} \mathrm{Am}$, and ${ }^{243} \mathrm{Crn}$. The associated inventories are given in: Table 8 with the zones of identified contamination. A further analysis was performed to determine if these inventories could exceed $100 \mathrm{nCV} / \mathrm{g}$ concentrations. Three potential zones of contamination were identified: AX2, AX4, and:AX6: The associated mobility of these transuranics is low with the exception of ${ }^{237} \mathrm{~Np}$. The identified concentrations of transuranics are expected to be found in the upper $3 \mathrm{~m}(10 \mathrm{ft})$ of backfill within the three zones of contamination.

\subsection{REFERENCES}

Agnew, S.F, J Boyer, T.A. Corbin, T.B. Duran, J.R. Fitzpatrick, K.A. Jurgensen, T.P. Ortiz, and m.:B.L.:Young, 1997a; Hanford Tank Chemical and Radionuclide Inventories: HDW:Model

Co Rev 4,LA-UR-96-3860, Los Alamos National Laboratory, Los Alámos, New Mexico, (W) January 1997 .

Agnew, S.F,, P.Baca, R.A. Corbin, T.B. Duran, and K.A. Jurgensen, 1997b, Waste Status and Transaction Record Summary (WSTRS Rev. 4), LA-UR-97-311, Rev. 0, Los Alamos n.i. National Laboratory, Los Alamos, New Mexico.

Anderson, J. D., 1990, A History of the 200 Area Tank Farms, WHC-MR-0132, Westinghouse Hanford Company, Richland, Washington, June.

Brevick, C. H.; 1996, Supporting Document for the Northwest Quadrant Historical Tank Content $\therefore$ Estimate:Report for AX-Tank Farm, WHC-SD-WM-ER-309, Rev 1, Westinghouse Hanford Company, Richland, Washington, June 28. से

DOE, 1997a, Vadose Zone Characterization Project at the Hanford Tank Farms, AX Tank Farm Preliminary Report, GJO-HAN-10, U. S. Department of Energy, Richland Operations A.men Office; Rỉchland; Washington, April.

aring

Nons as 
DOE, 1997b, Vadose Zone Characterization Project at the Hanford Tank Farms, Tank Summary Data Report for Tank AX-101, GJ-HAN-49, U.S. Department of Energy, Grand Junction Office, Grand Junction, Colorado, January.

DOE, $1997 \mathrm{c}$, Vadose Zone Characterization Project at the Hanford Tank Farms, Tank Summary Data Report for Tank AX-102, GJ-H.AN-50, U.S. Department of Energy, Grand Junction Office, Grand Junction, Colorado, January.

DOE, 1997 d, Vadose Zone Characterization Project at the Hanford Tank Farms, Tank Summary Data Report for Tank AX-103, GJ-HAN-51, U.S. Department of Energy, Grand Junction Office, Grand Junction, Colorado, January.

DOE, 1997e, Vadose Zone Characterization Project at the Hanford Tank Farms, Tank Summary Data Report for Tank AX-104, GJ-HAN-52, U.S. Department of Energy, Grand Junction Office, Grand Junction, Colorado, January 1997.

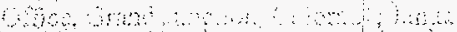

Kelly, D.I, 1994, DSI- East Tank Farms History, March 6, 1994 to East Tank Farm Managers. Mercier, P.F, 1990, Survey of Single-Shell Tank Histories, RHO-CD-1 172, Rockwell Hanford Operations, Richland, Washington, October 29.

RHO, 1990; Handbook - 200 Areas. Waste Sites RHO-CD-673, Rockwell Hanford Operations, Richland, Washington, December 7.

Routson, R.C., D.J. Brown, K.R. Fecht, W.H. Price, 1979, High-Level Waste Leakage From the 241-T-106 Tank at Hanford, RHO-ST-14, Rockwell Hanford Operations, Richland, Washington.

Welty, R.K., 1991. Waste Storage Tank Status and Leak Detection Criteria, SD-WM-TI-356, Rev. 0, Westinghouse Hanford Company, Richland, Washington, March 21 . 
HNF-SD-HTI-TI-001, REV. 0

SESC-EN-RPT-002, Rev. 0

(formal7y known as)

Figure 1. General Site and Plumes

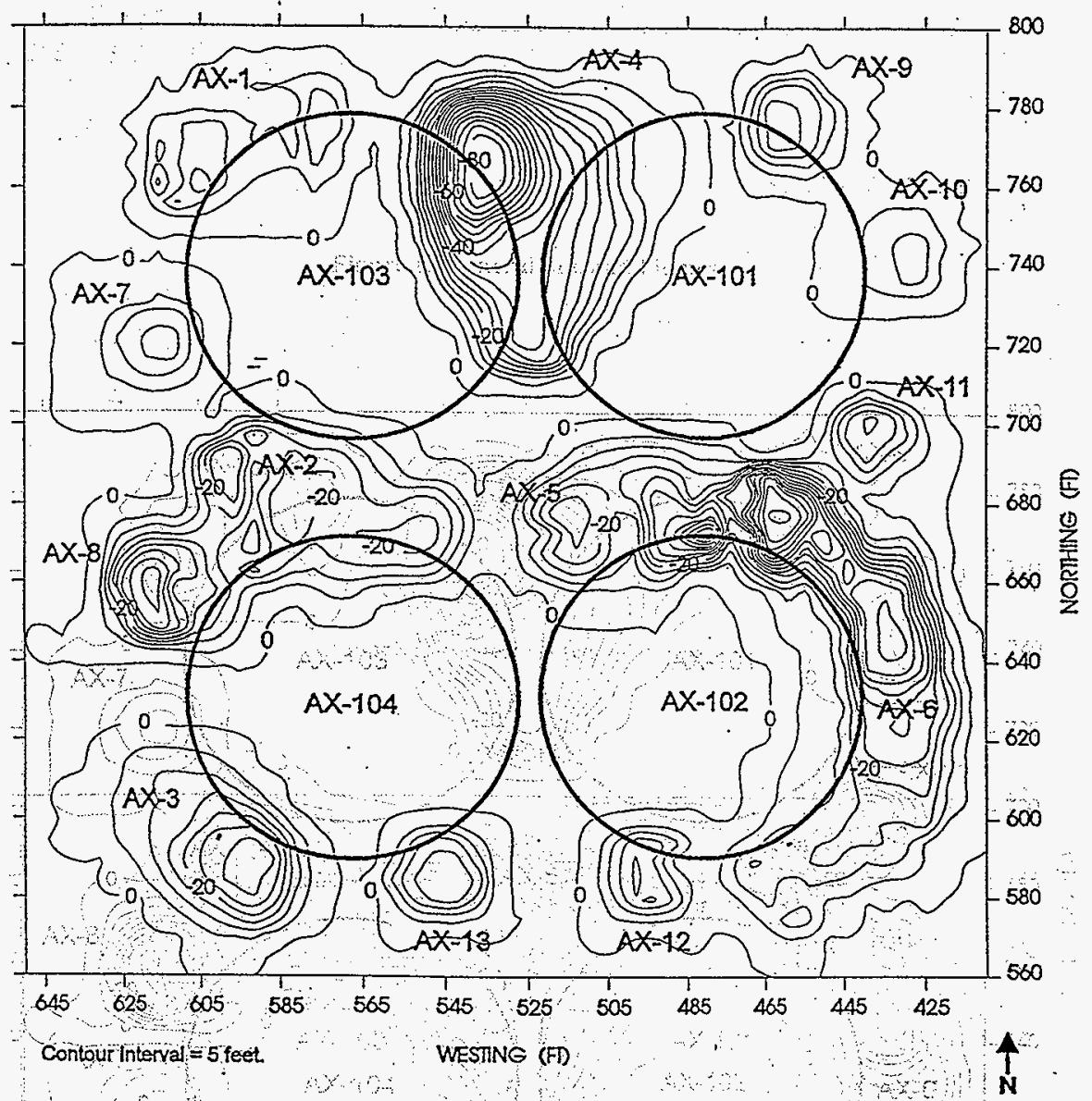


HNF-SD-HTI-TI-001, REV. 0

Figure 2. AX1 - Contaminated Area
SESC-EN-RPT-002, Rev. 0

(formally known as)

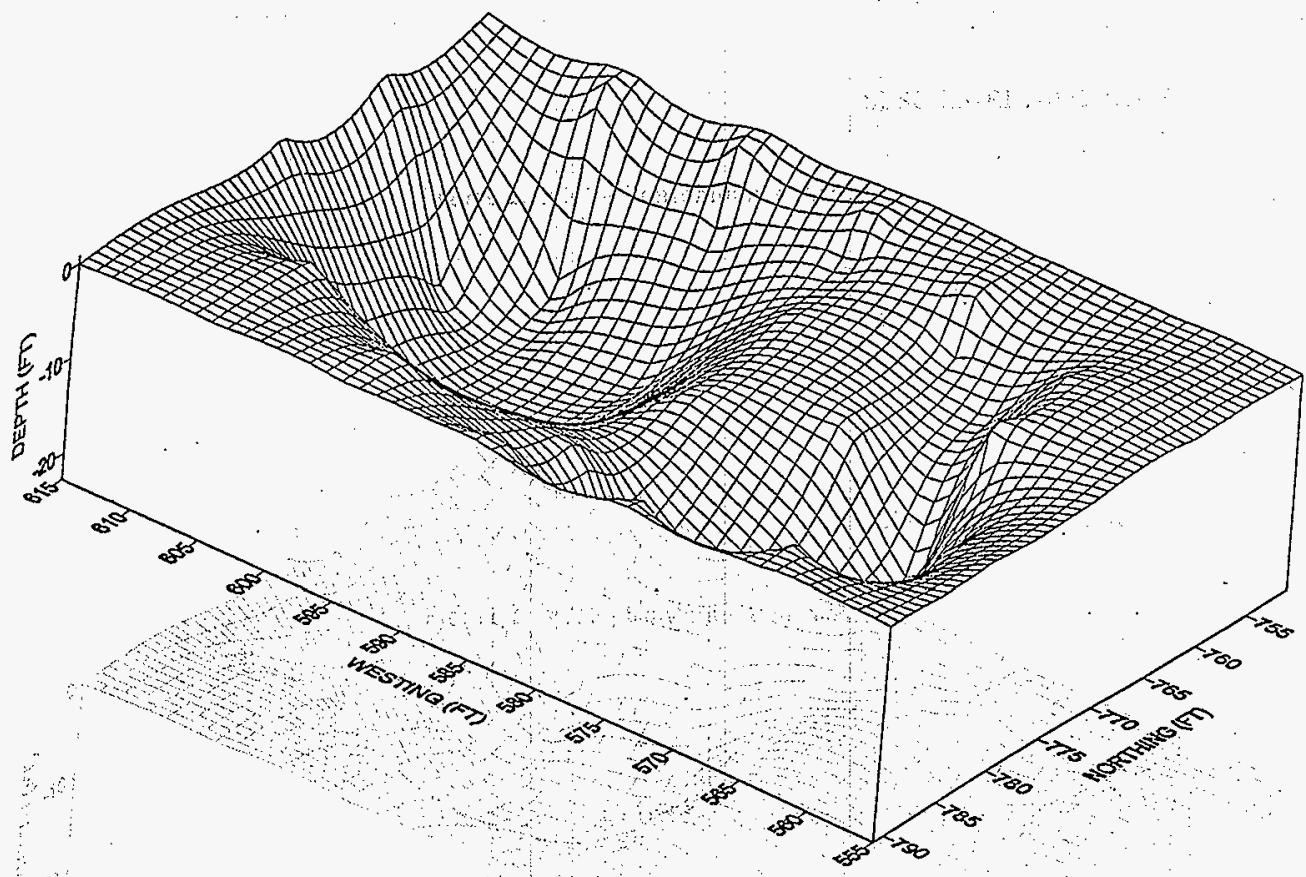


Figure 3. AX1 - Contour Map

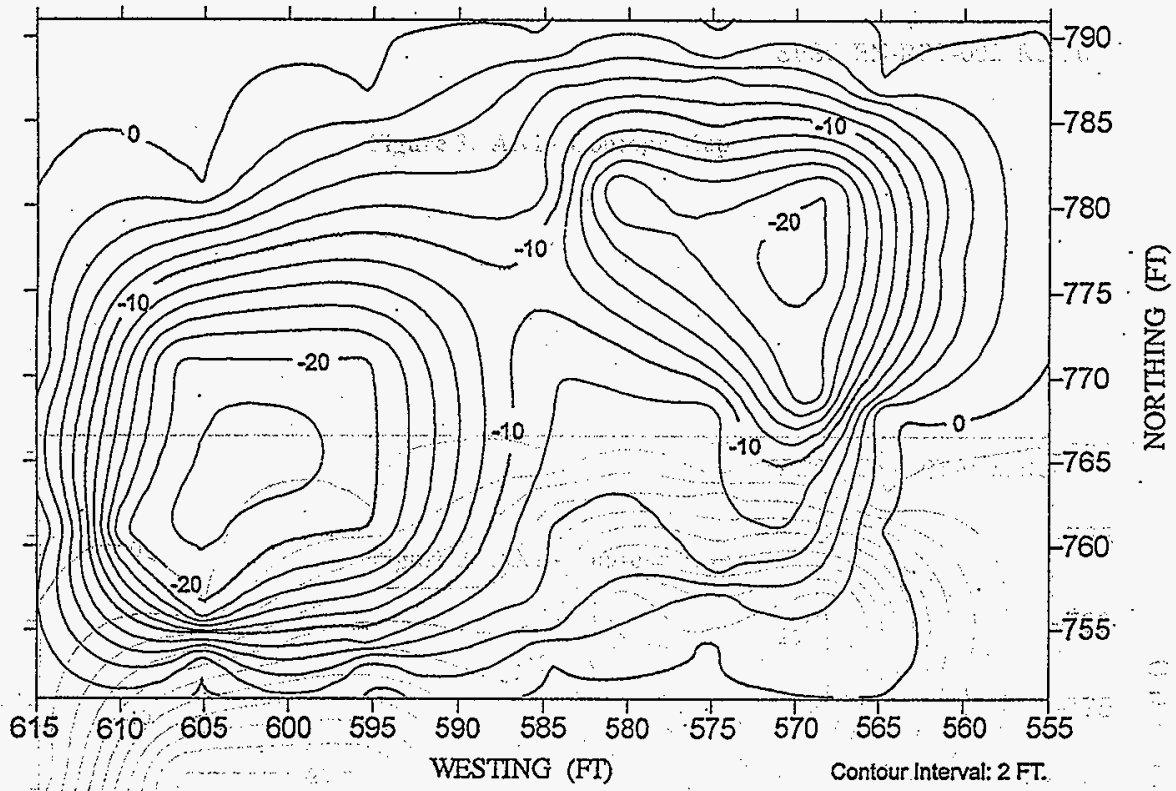


Figure 4. AX4 - Contaminated Area

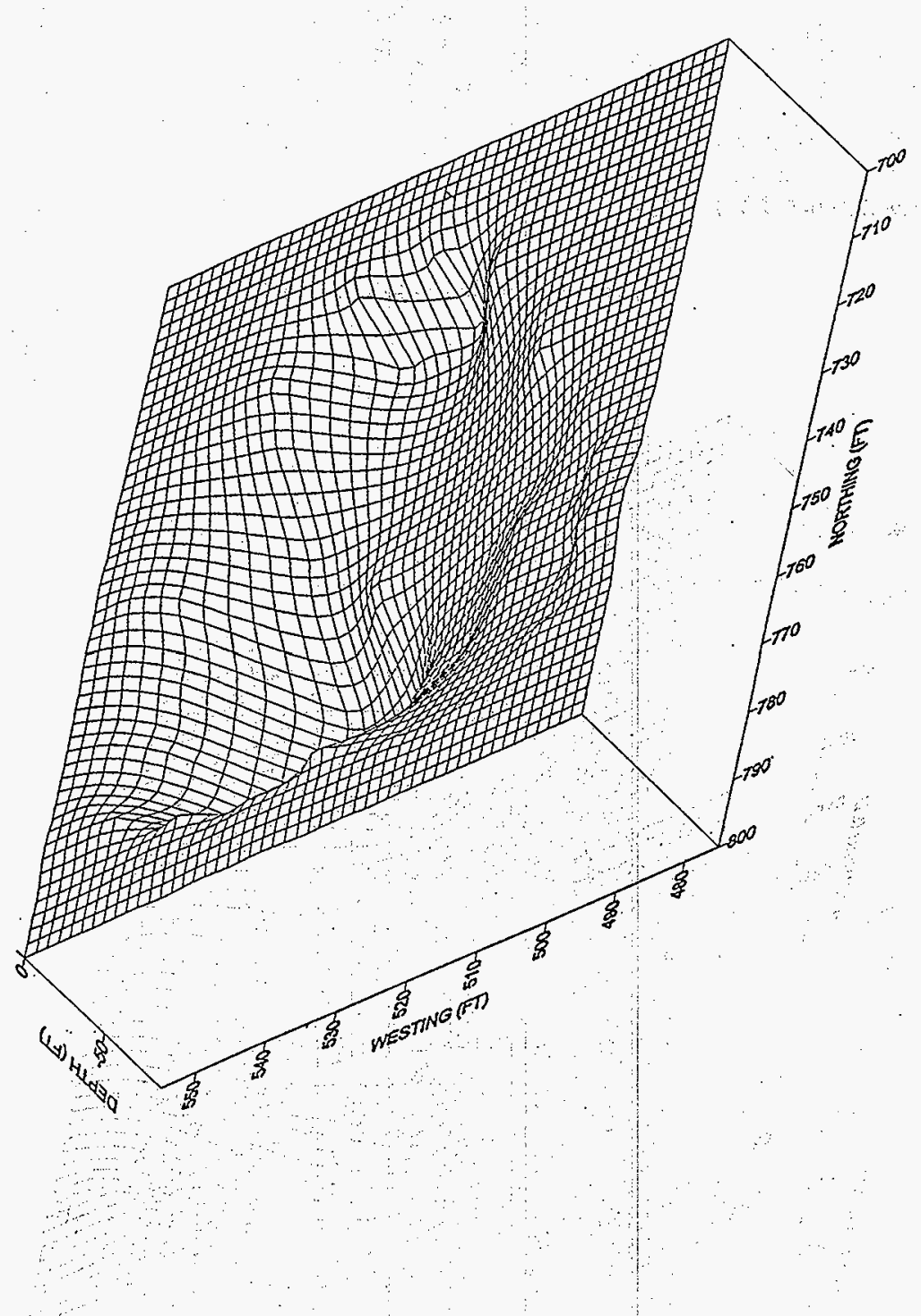


Figure 5. AX4 - Contour Map

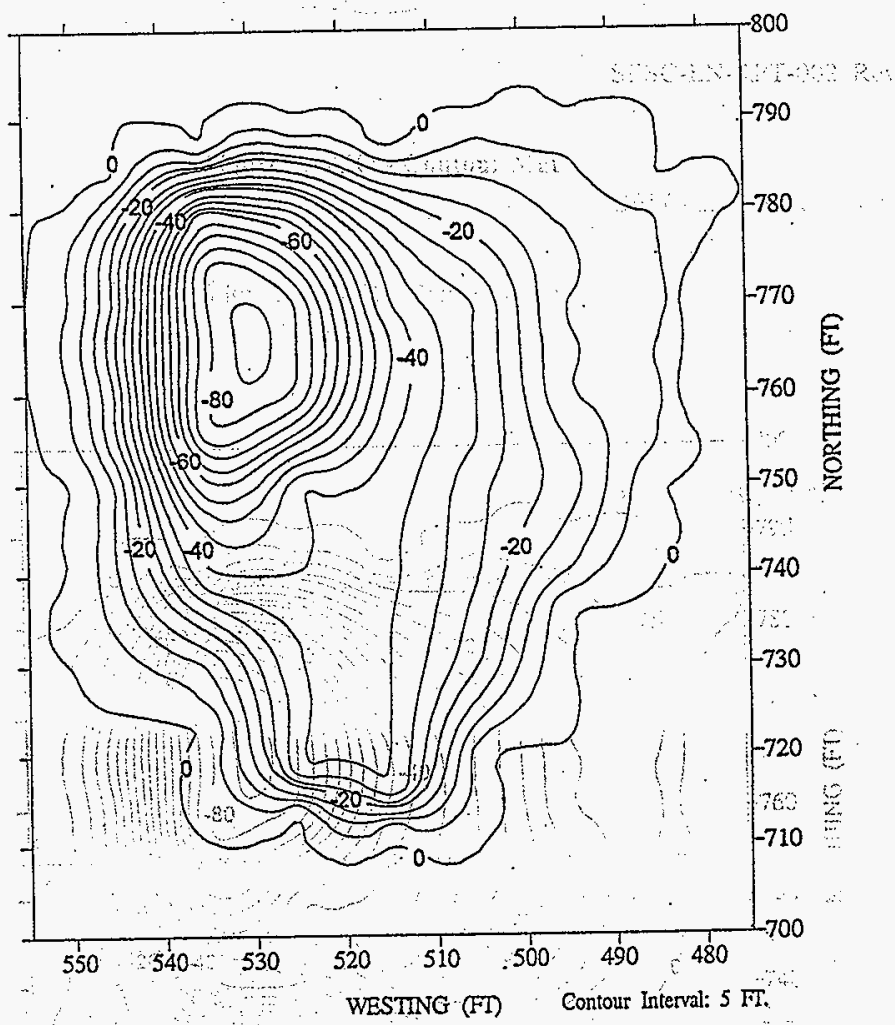


Figure 6. AX2 - Contaminated Area

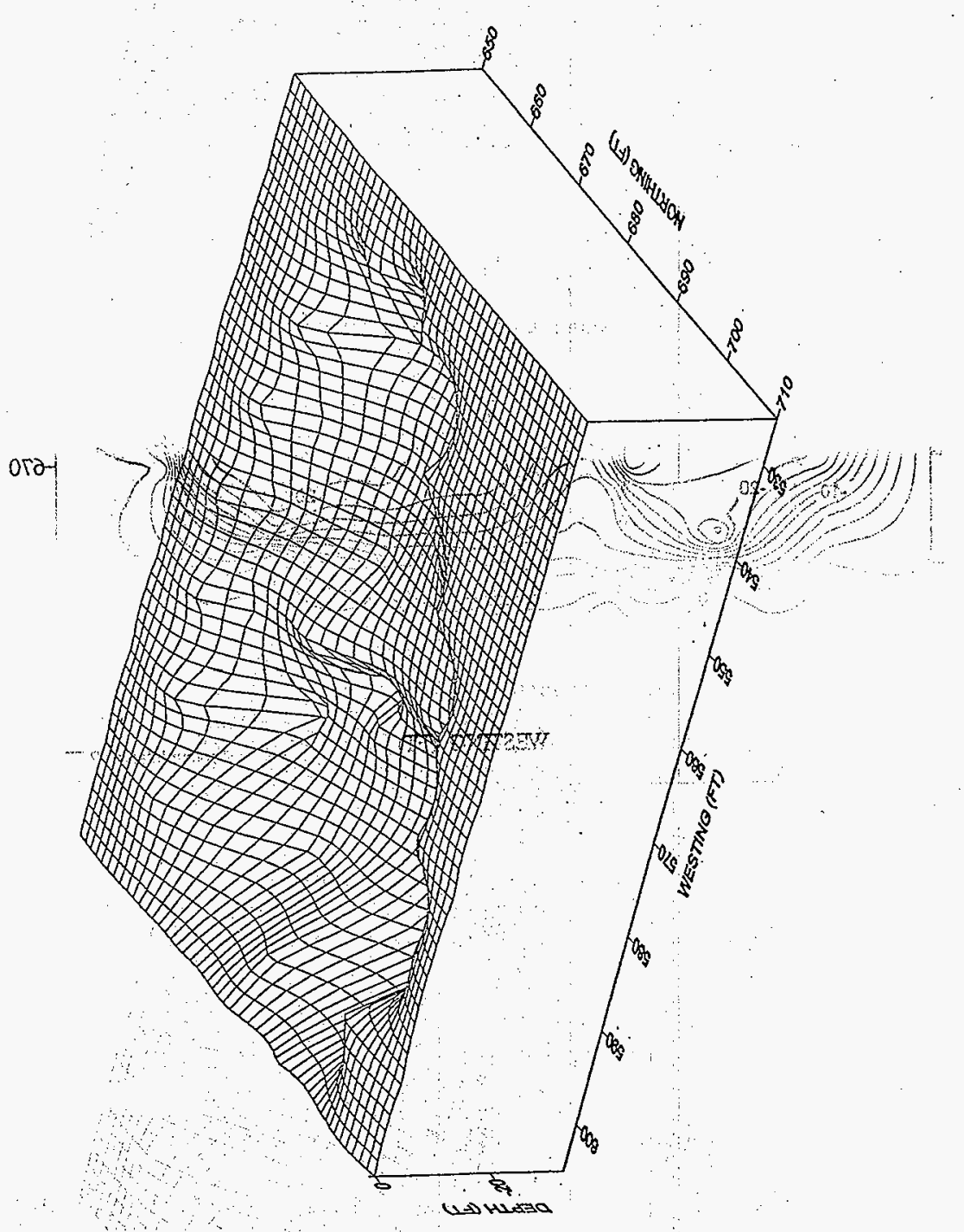

FF-6 
HNF-SD-HTI-TI-001, REV. 0

Figure 7. AX2 - Contour Map
SESC-EN-RPT-002, Rev. 0

(formally known as)

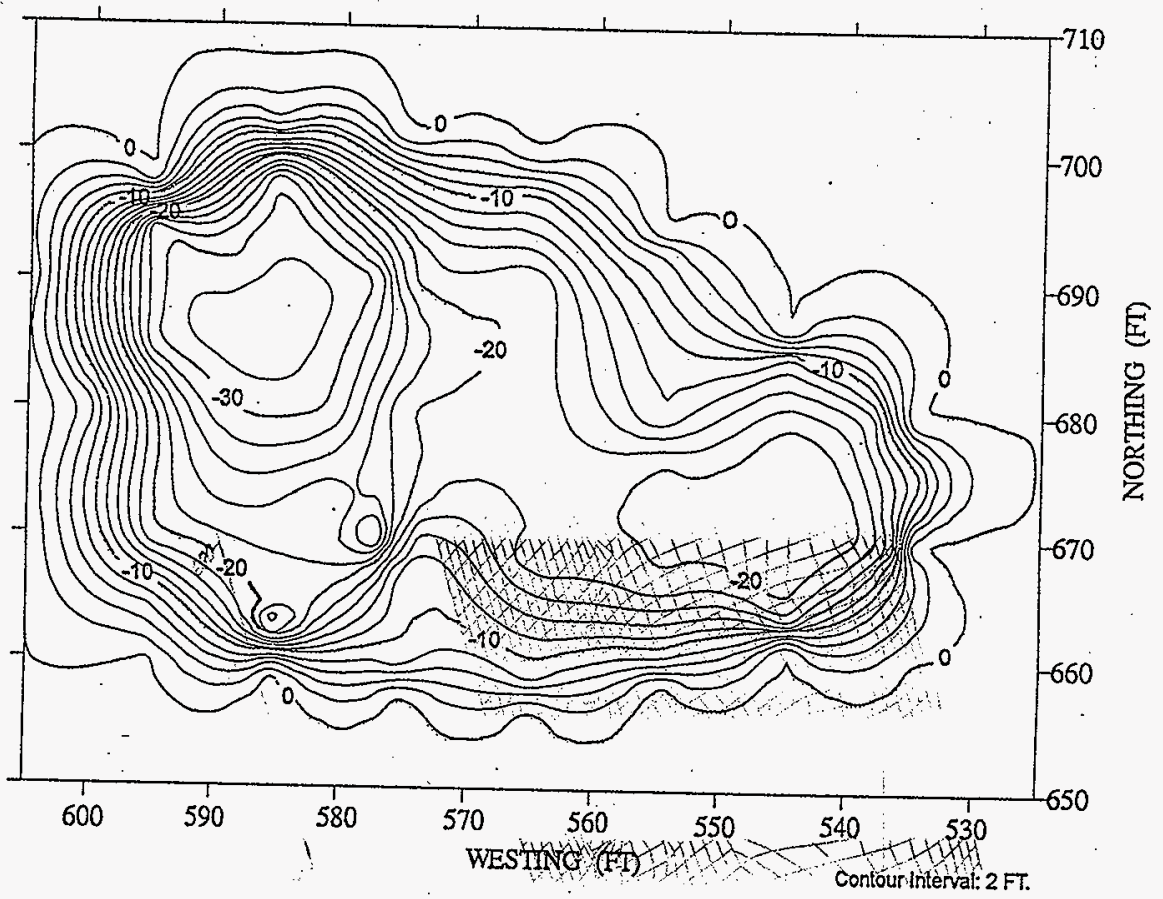


HNF-SD-HTI-TI-001, REV. 0

SESC-EN-RPT-002, Rev. 0

(formally known as)

Figure 8. AX5 - Contaminated Area

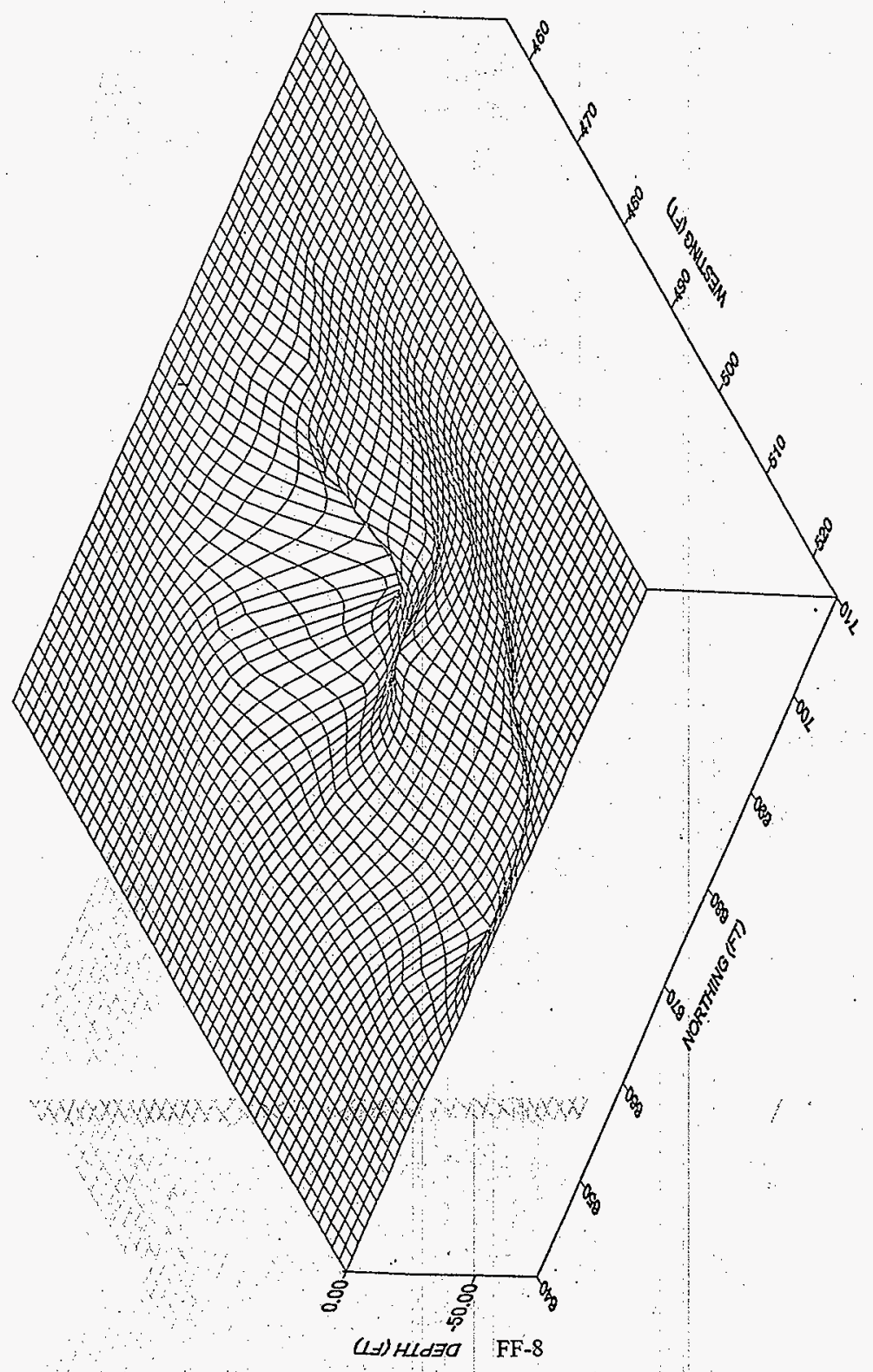


Figure 9. AX5 - Contour Map

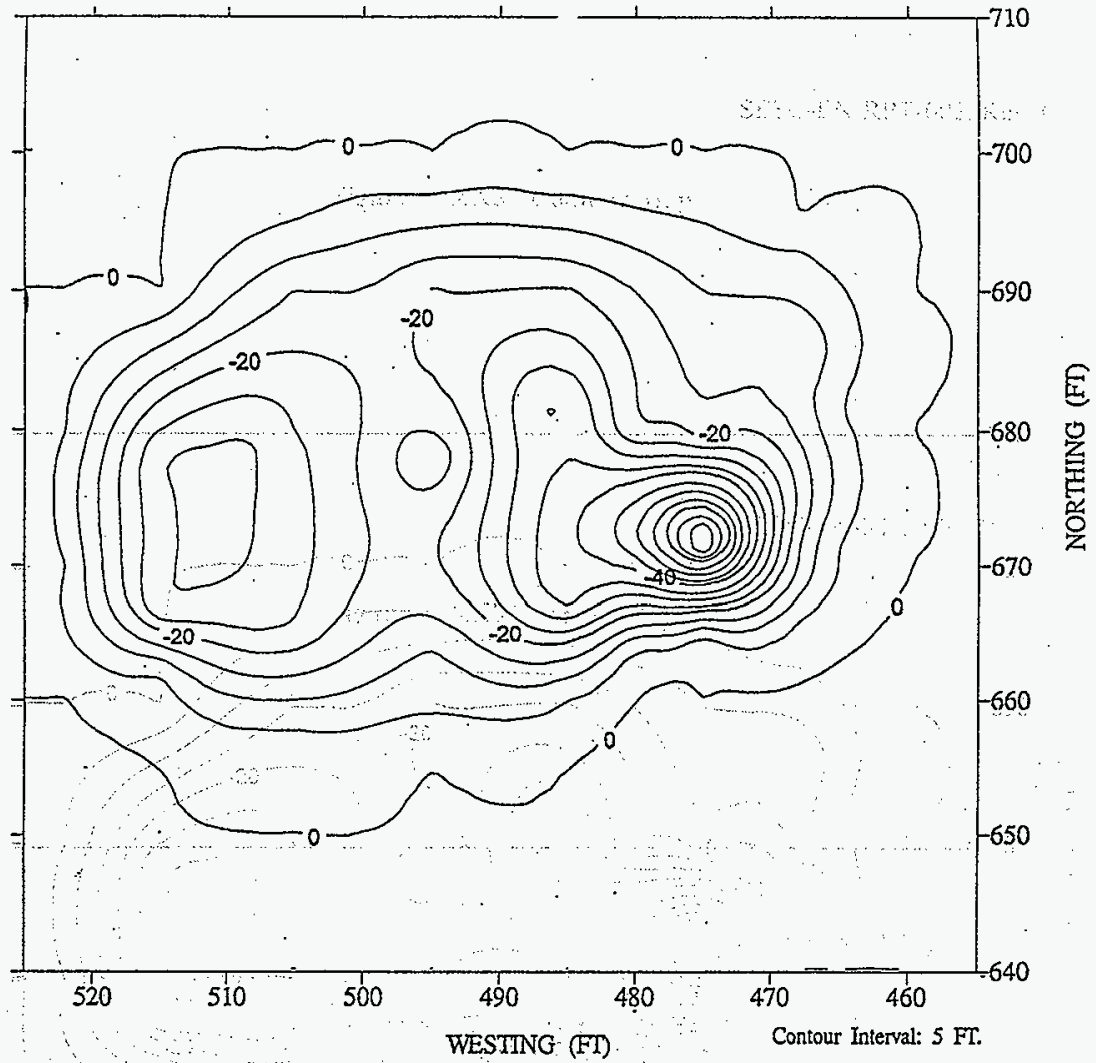


(formally known as)

Figure 10. AX3 - Contaminated Area

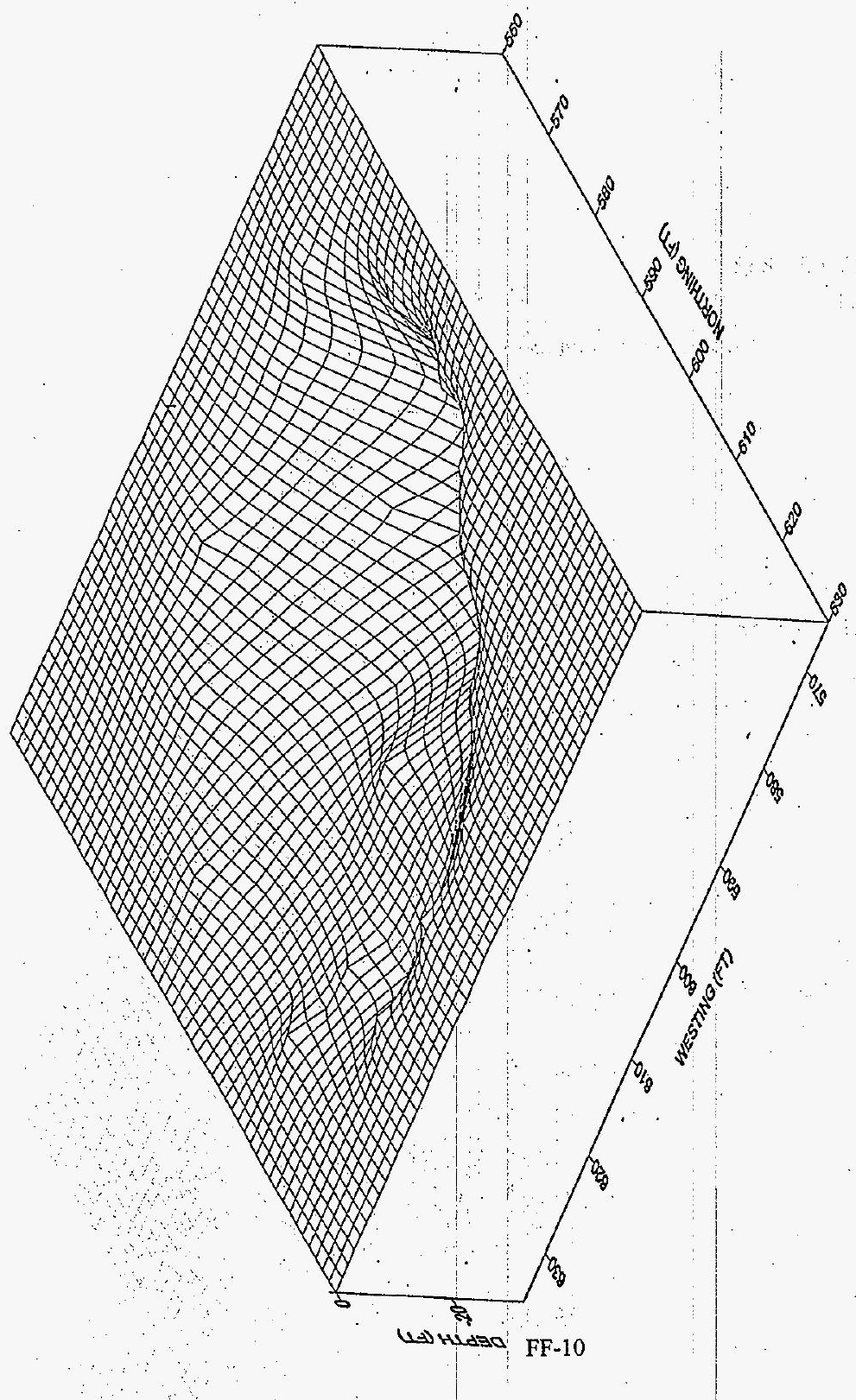


Figure 11. AX3 - Contour Map

(formally known as)

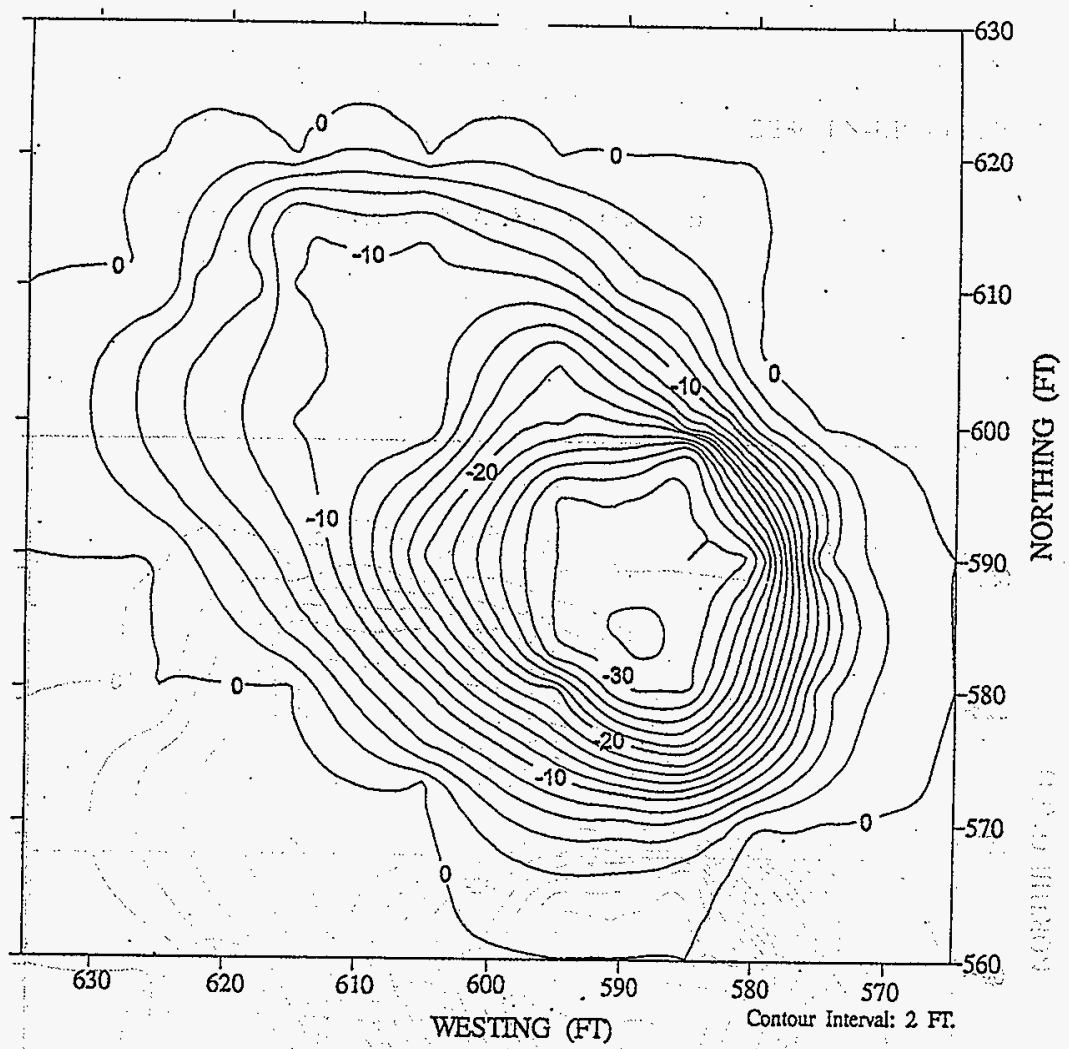


Figure 12. AX6 - Contaminated Area

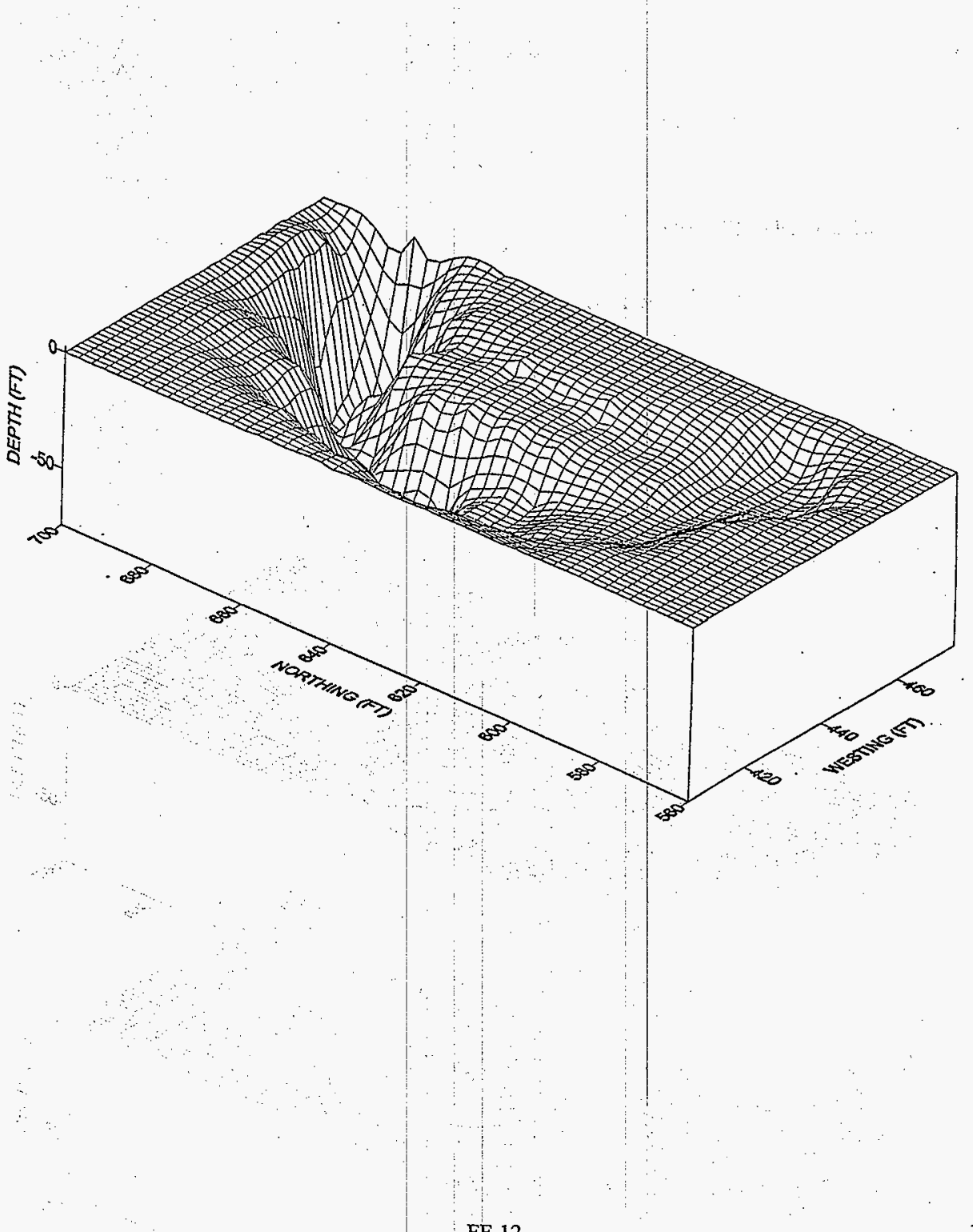


Figure 13. AX6 - Contour Map

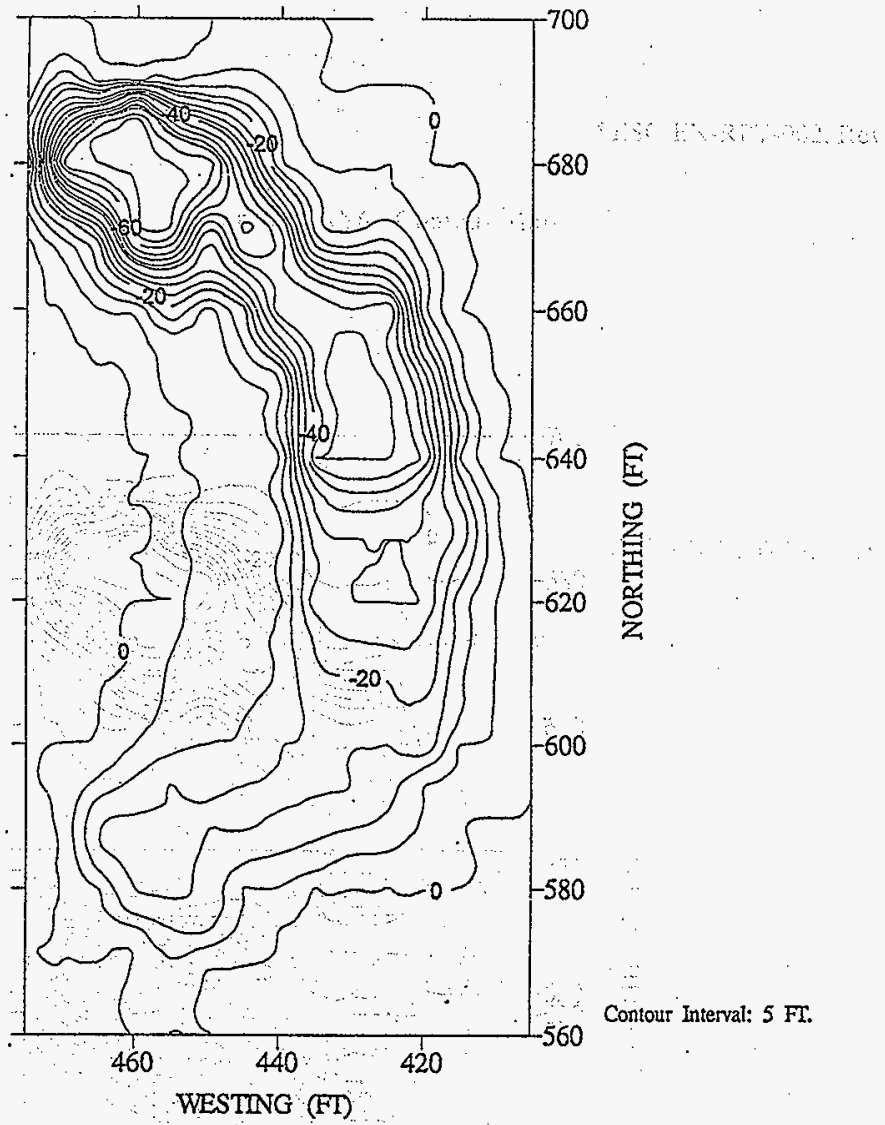


(formally known as)

Figure 14. AX7 - Contaminated Area

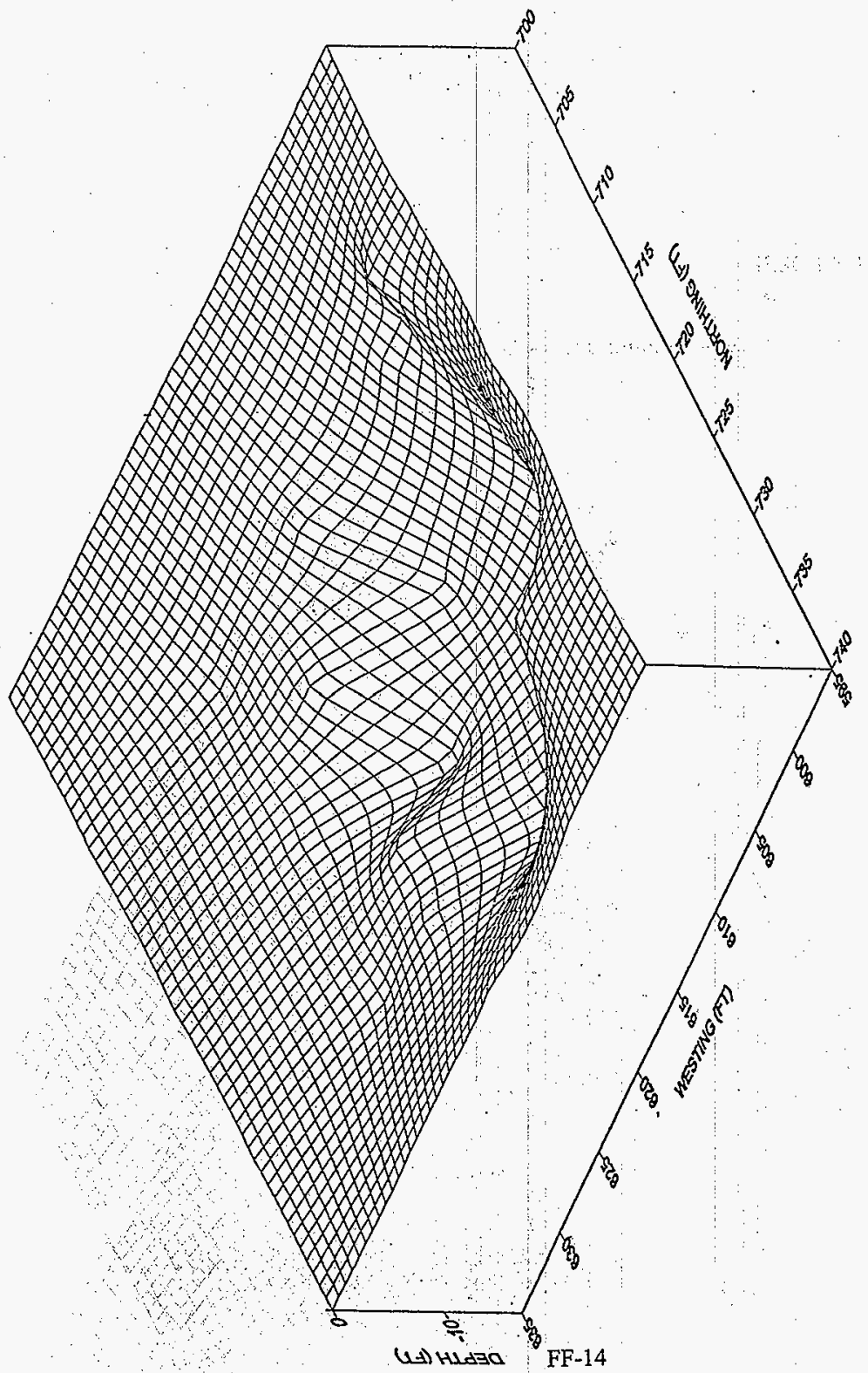


(formally known as)

Figure 15. AX7 - Contour Map

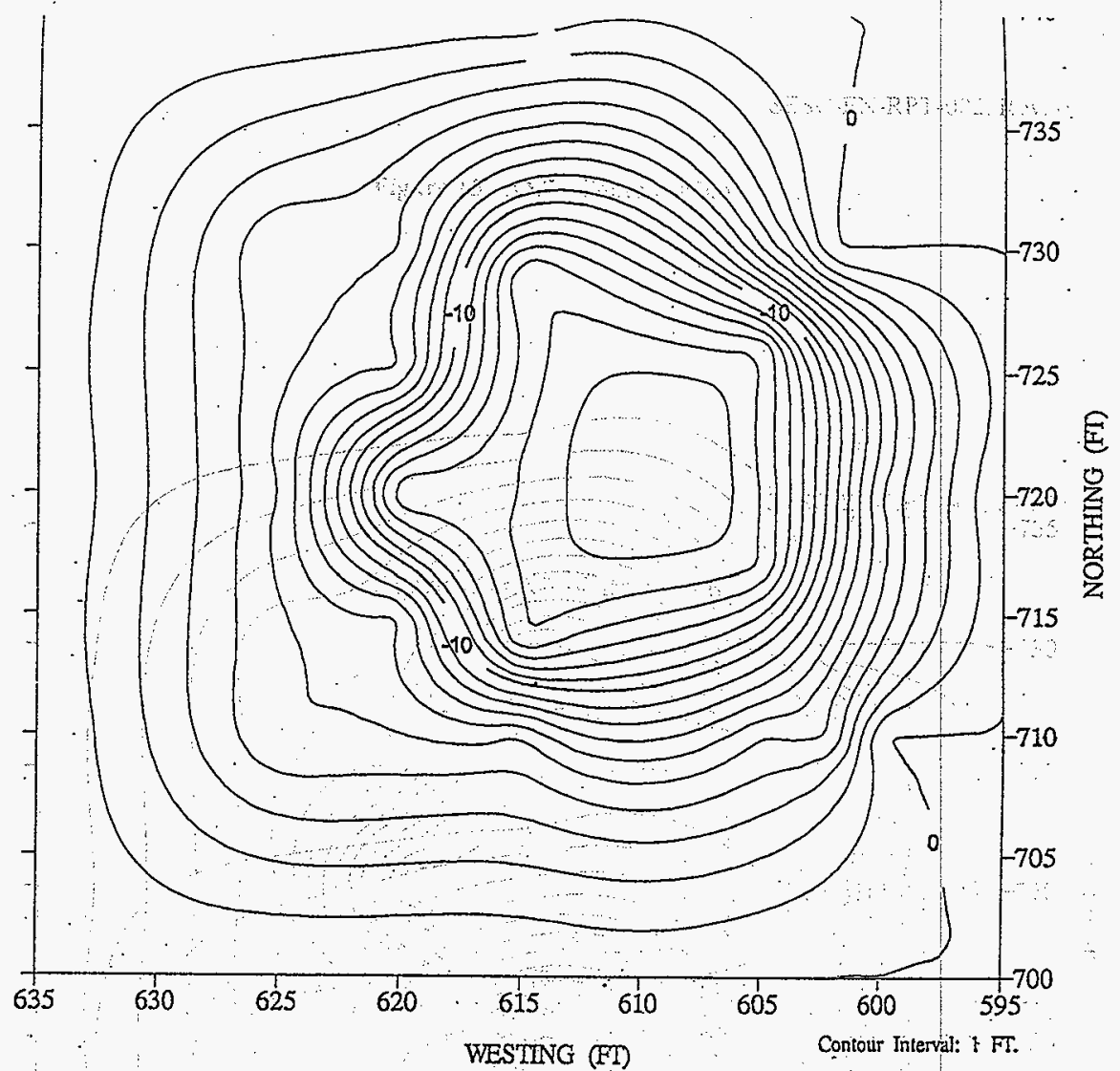


(formally known as)

Figure 16. AX8 - Contaminated Area

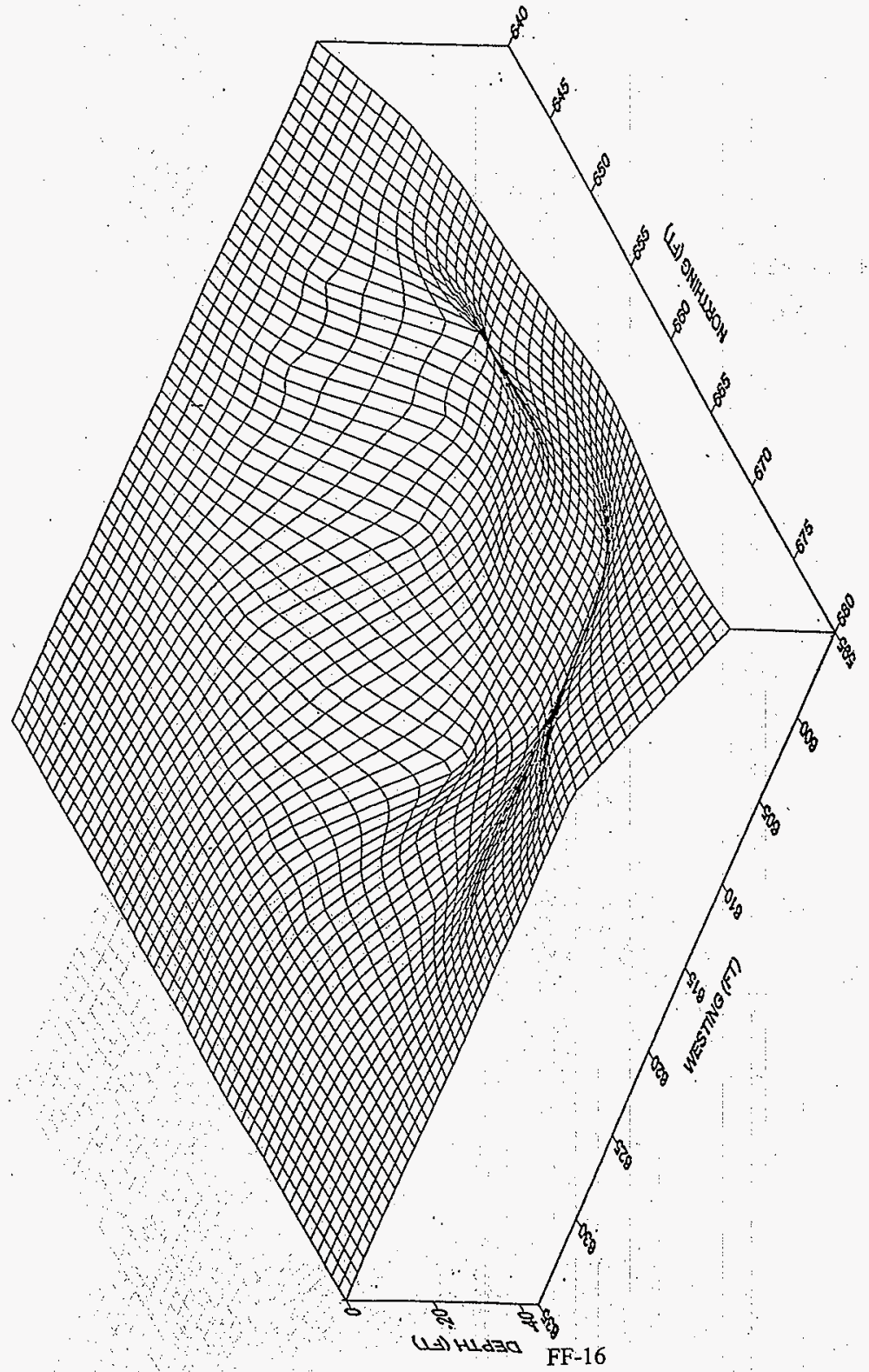


HNF-SD-HTI-TI-001, REV. 0

Figure 17. AX8 - Contour Map
SESC-EN-RPT-002, Rev. 0

(formaliy known as)

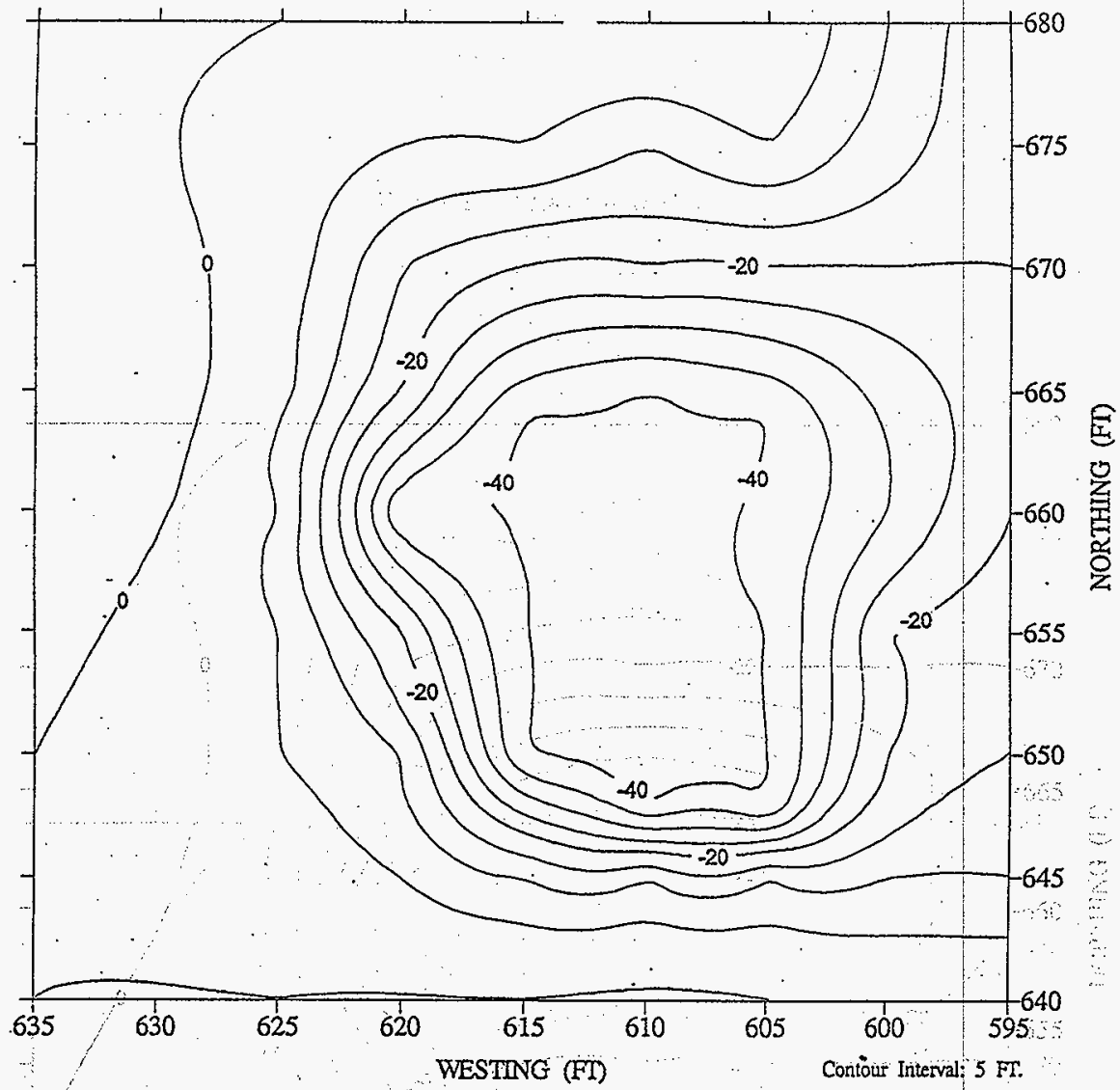


Figure 18. AX9 - Contaminated Area

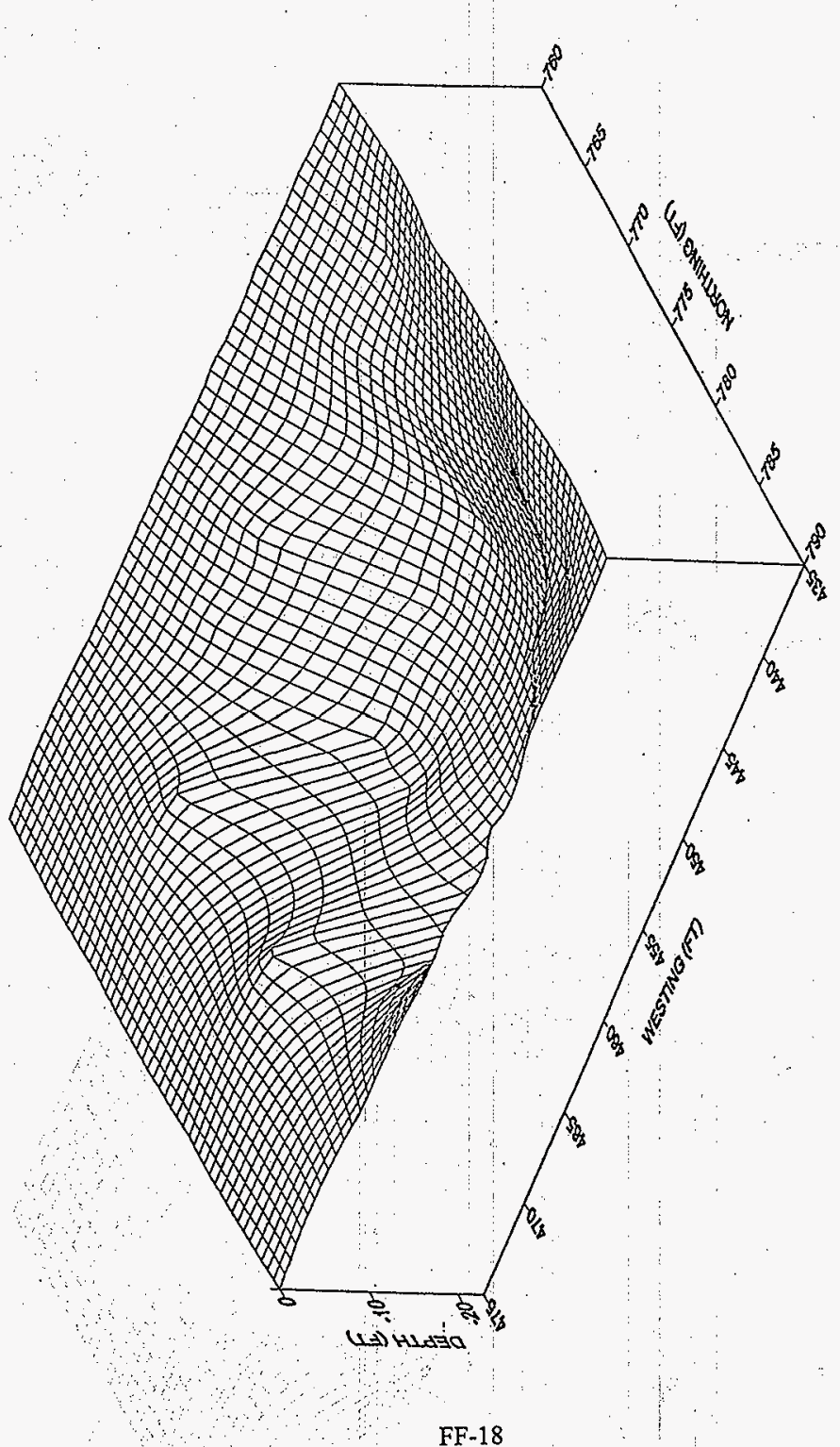


HNF-SD-HTI-TI-001, REV. 0

Figure 19. AX9 - Contour Map
SESC-EN-RPT-002, Rev. 0

(formally known as)

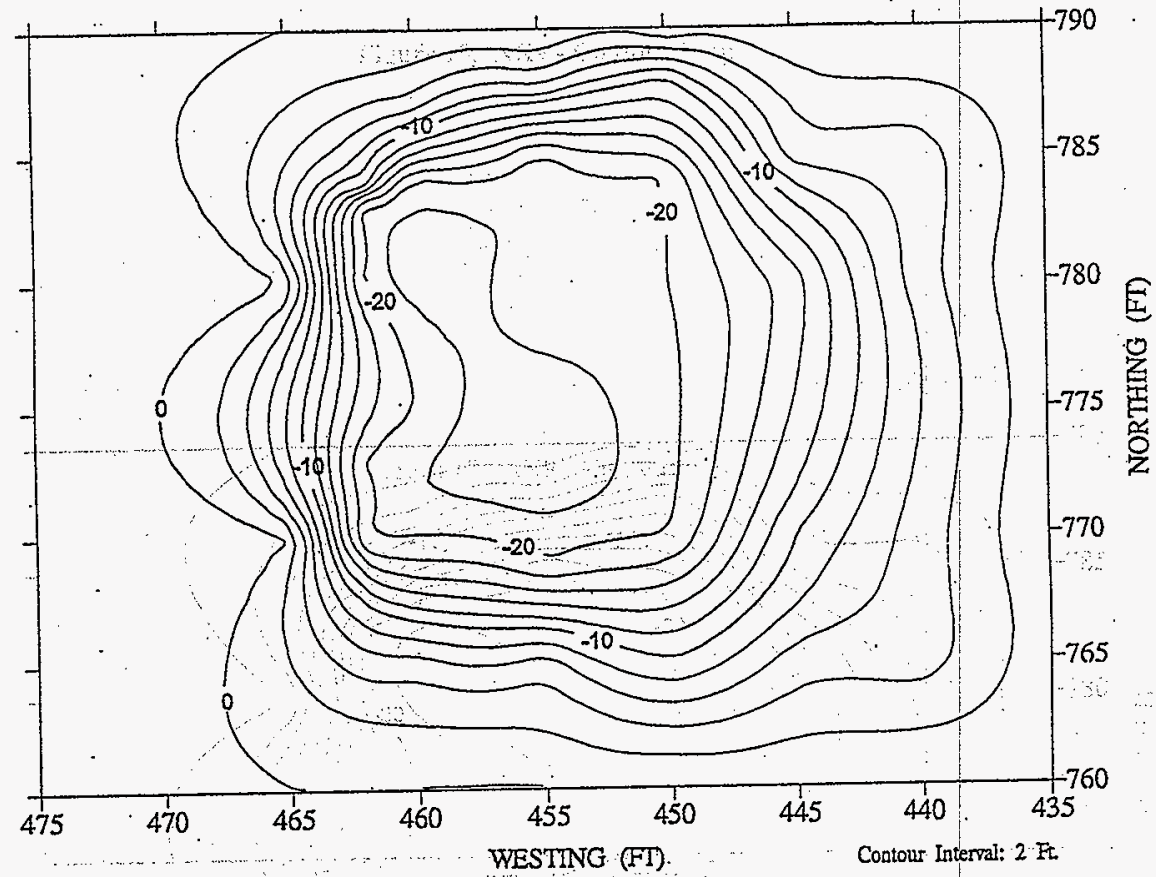


HNF-SD-HTI-TI-001, REV. 0

SESC-EN-RPT-002, Rev. 0

Figure 20. AX10 - Contaminated Area

(formally known as)

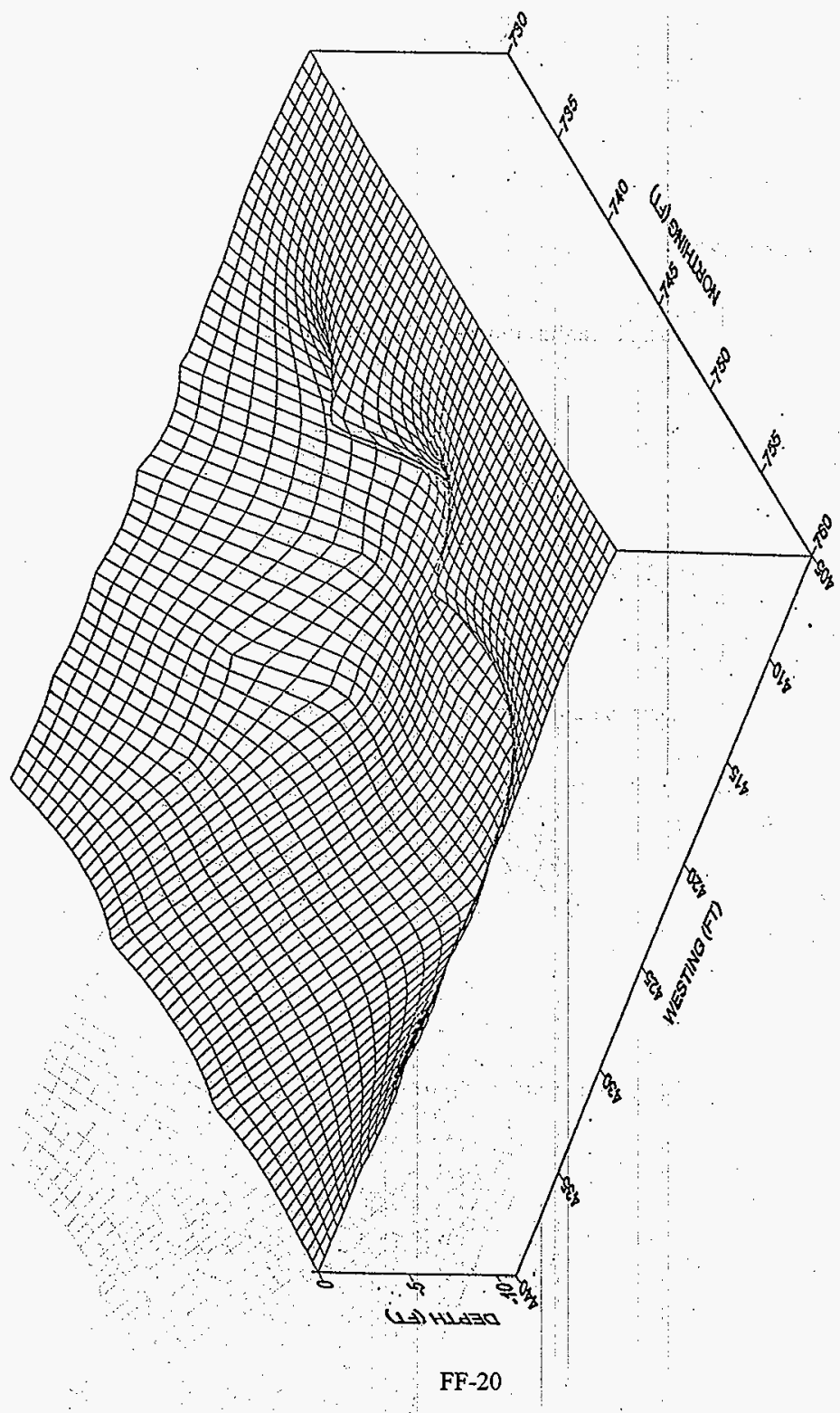


Figure 21. AX10 - Contour Map

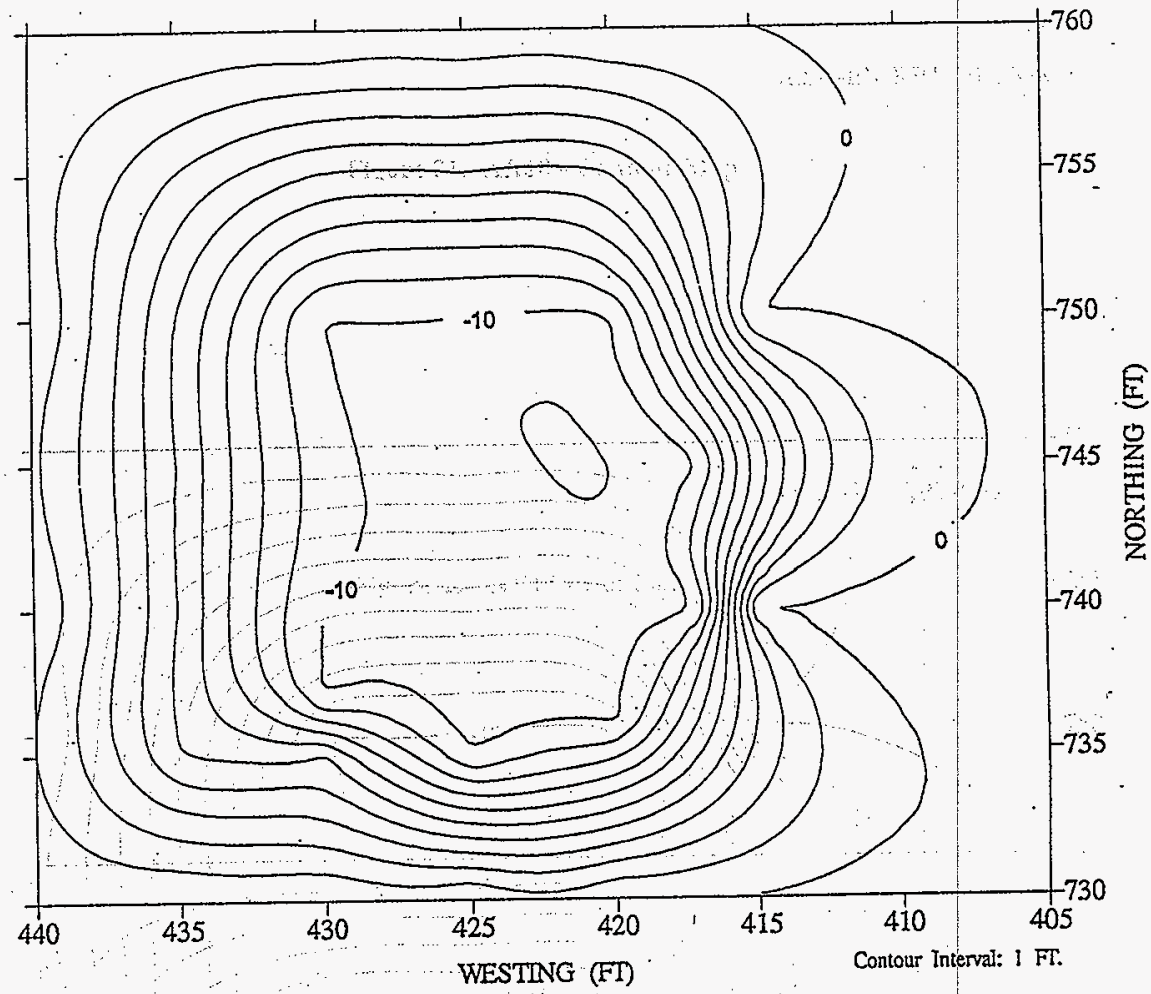


HNF-SD-HTI-TI-001, REV. 0

SESC-EN-RPT-002, Rev. 0

(formally known as)

Figure 22. AX11 - Contaminated Area

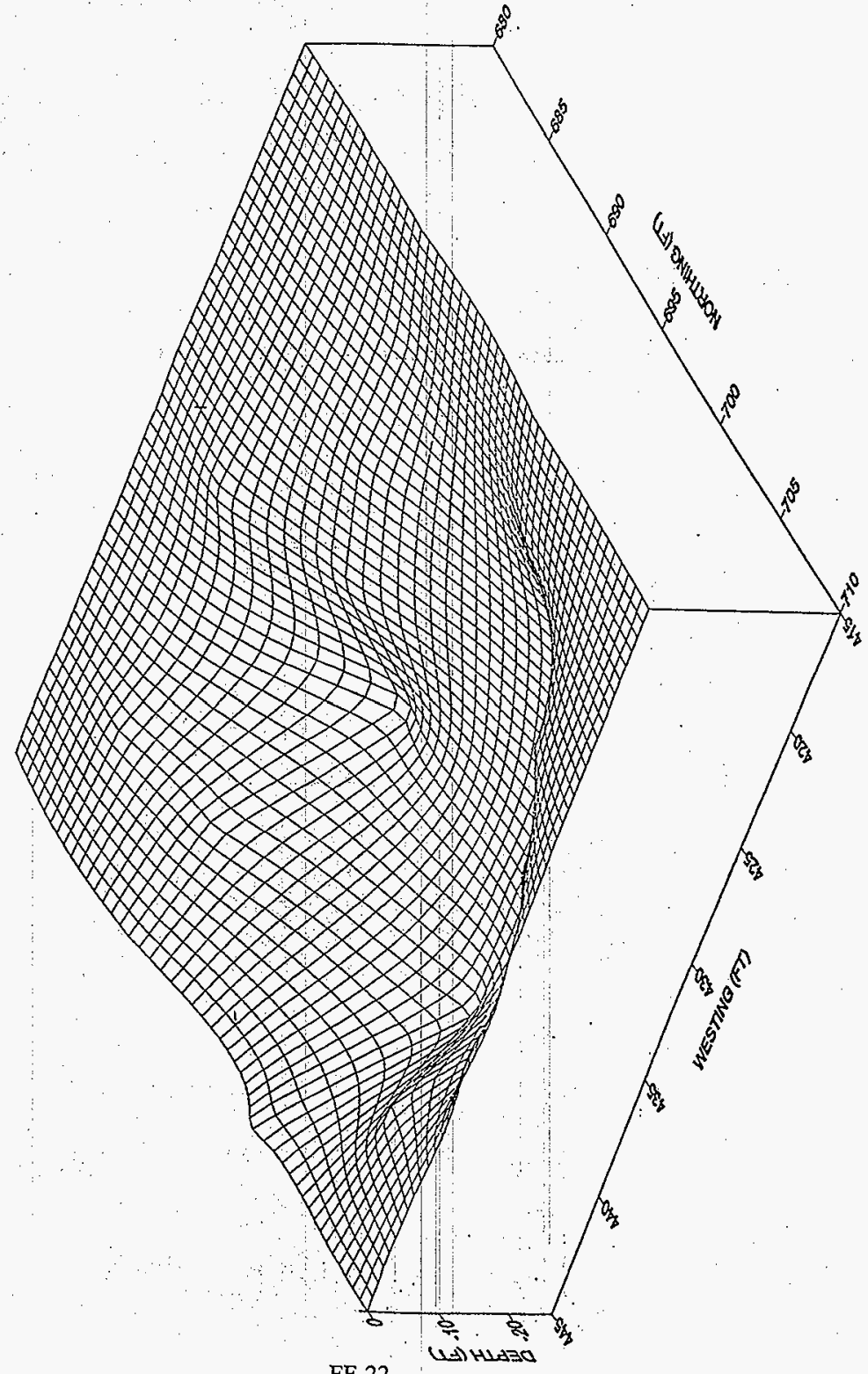

FF-22 


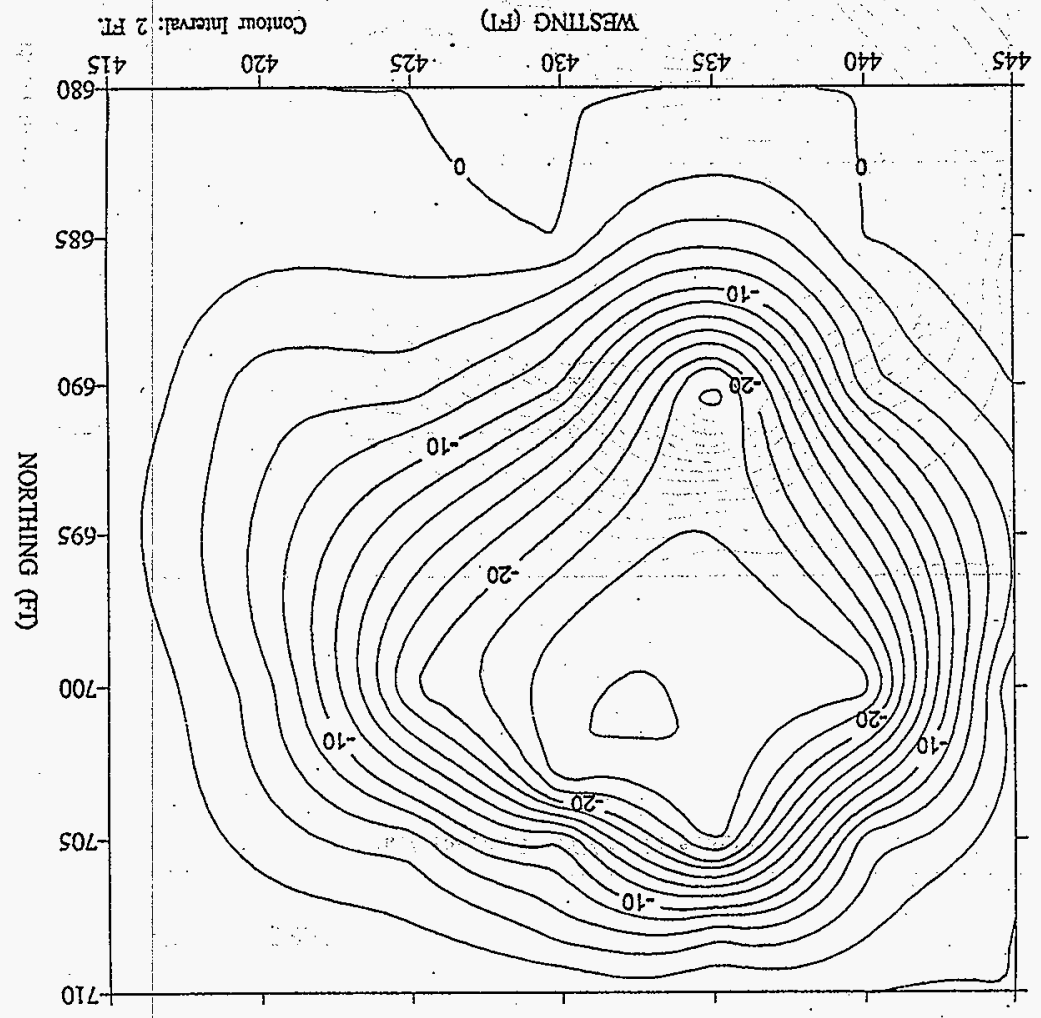


Figure 24. AX12 - Contaminated Area

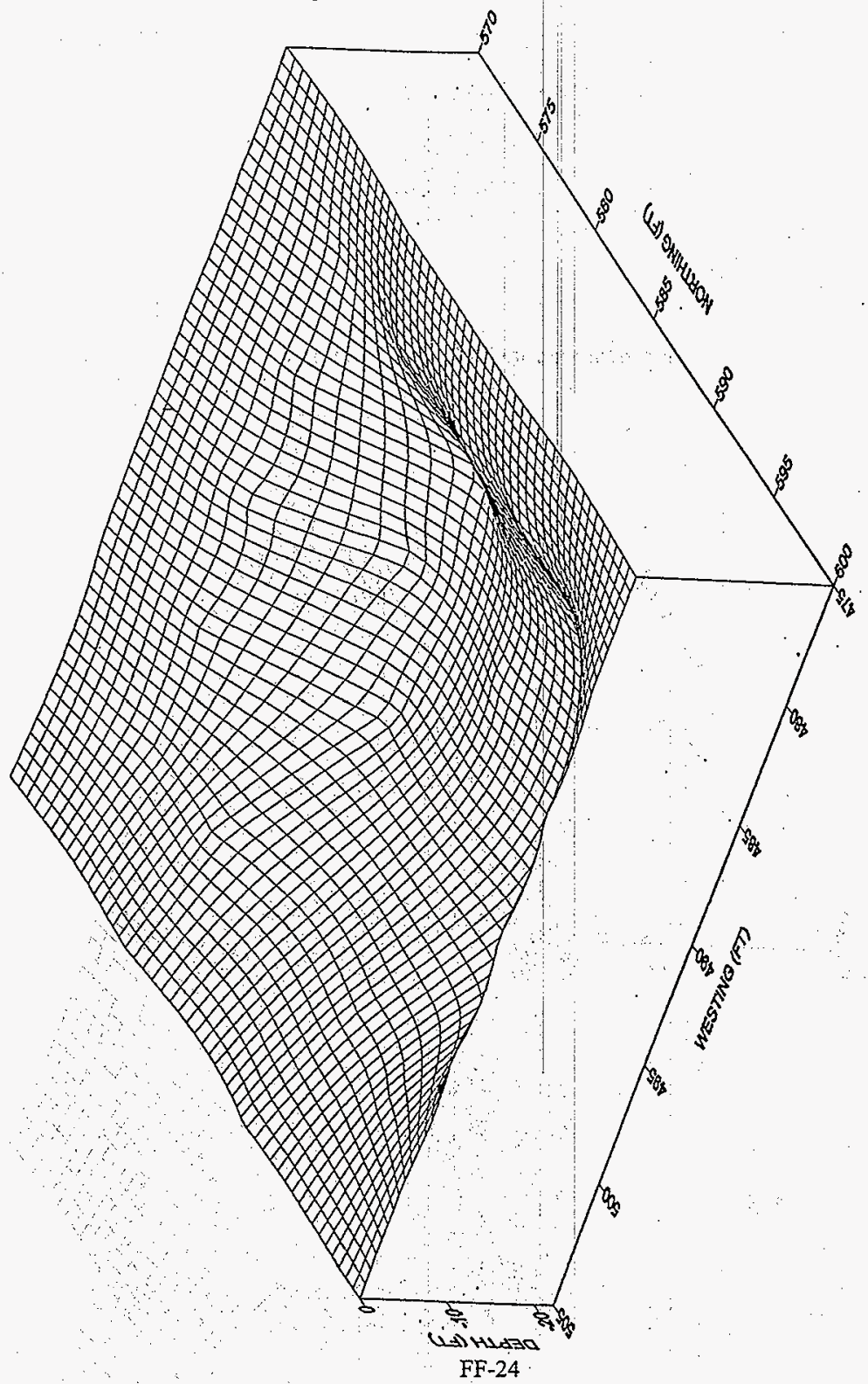


HNF-SD-HTI-TI-001, REV. 0

Figure 25. AX12 - Contour Map
SESC-EN-RPT-002, Rev. 0

(formally known as)

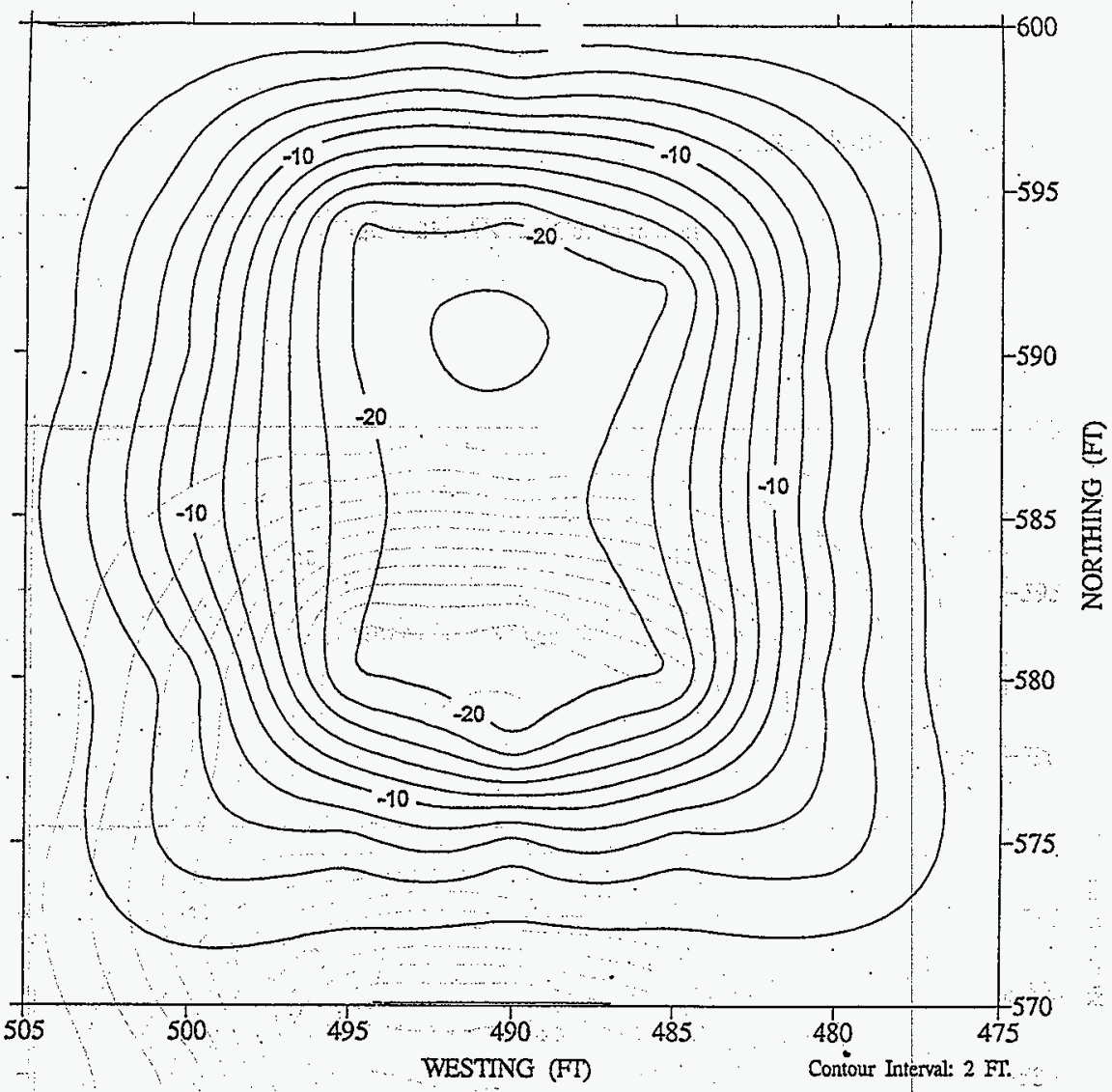


(formally known as)

Figure 26. AX13 - Contaminated Area

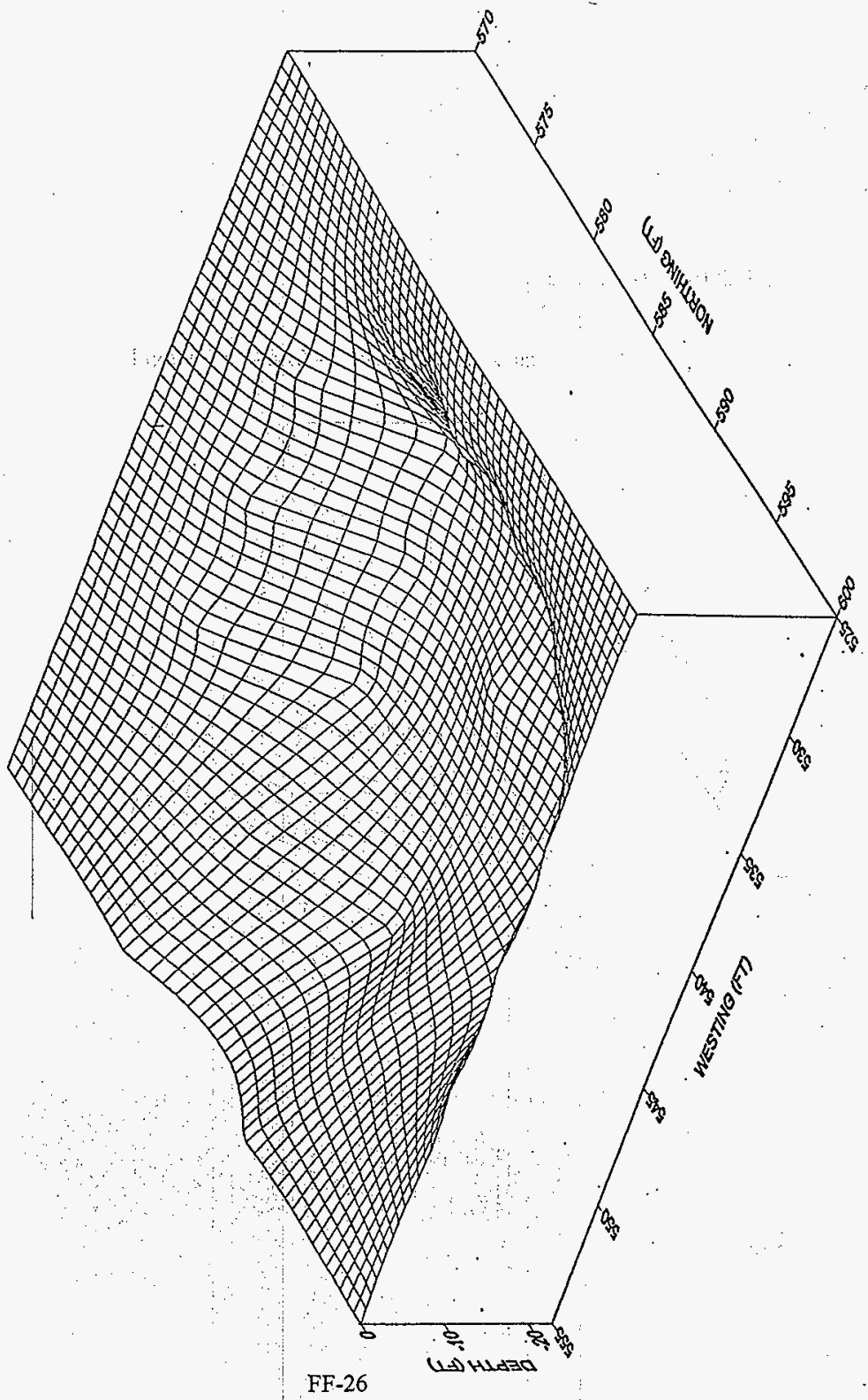


HNF-SD-HTI-TI-001, REV. 0

Figure 27. AX13 - Contours Map
SESC-EN-RPT-002, Rev. 0

(formaliy known as)

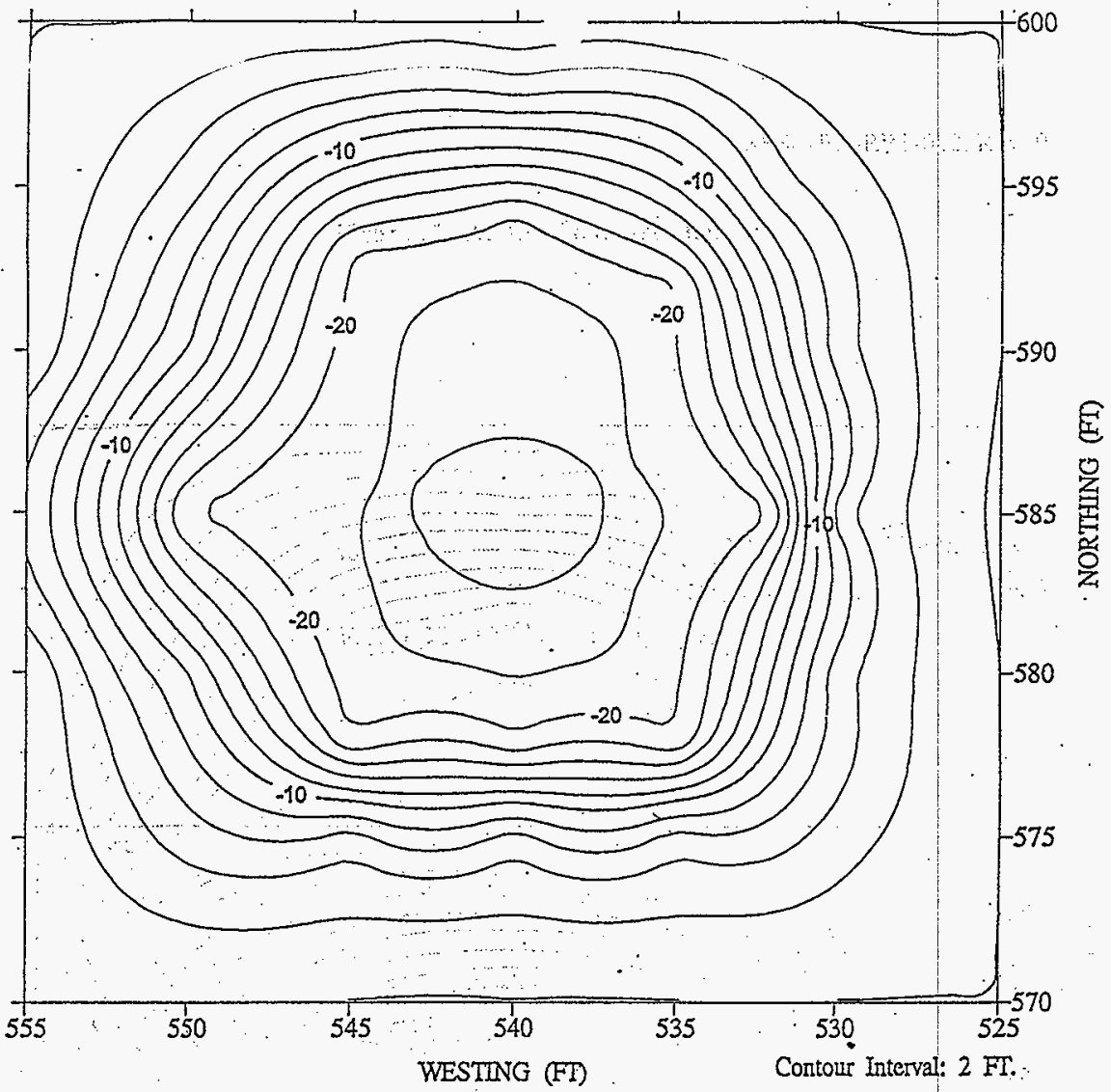



HNF-SD-HTI-TI-001, REV. 0

SESC-EN-RPT-002, Rev. 0

(formally known as)

Table 1. Summary of Contamination Releases

\begin{tabular}{|l|l|l|l|}
\hline $\begin{array}{c}\text { Release } \\
\text { Order }\end{array}$ & \multicolumn{1}{|c|}{ AX-Farm Location } & \multicolumn{1}{|c|}{ Quantity } & \multicolumn{1}{|c|}{ Description } \\
\hline 1 & Northwest & $40 \mathrm{~L}$ & PSS \\
\hline 2 & Northcentral & $40 \mathrm{~L}$ & $\begin{array}{l}48.9 \% \text { OWW2 } \\
51.1 \% \text { IWW }\end{array}$ \\
\hline 3 & Central Northwest & $80 \mathrm{~L}$ & OWW2 \\
\hline $4 \& 5$ & Central and Centraleast & $11.360 \mathrm{~L}$ & OWW3 \\
\hline 6 & Central and Southwest & $30.280 \mathrm{~L}$ & IWW \\
\hline $7 \ldots \ldots$ & Southeast & $20 \mathrm{~L}$ & $\begin{array}{l}12 / 76 \text { B Plant } \\
\text { Sludge Recovery } \\
(10 \%) / \text { Sluice water }\end{array}$ \\
\hline
\end{tabular}


HNF-SD-HTI-TI-001, REV. 0

SESC-EN-RPT-002, Rev. 0

(formally known as)

Table 2. Contaminant Stream Compositions (page 1 of 2)

\begin{tabular}{|c|c|c|c|c|c|c|c|}
\hline \multicolumn{3}{|c|}{ 241-AX Farm Release Estimates } & \multicolumn{5}{|c|}{ Concentrations - $\mathrm{mol} / \mathrm{L}$} \\
\hline Region & NW. & NC & NC & CNW & C\&CE & C\&SW & $\overline{S E}$ \\
\hline $\begin{array}{l}\text { Assoc. } \\
\text { Tank }\end{array}$ & $103-A X$ & 103-AX & $103-A x$ & $102-A X$ & $102-A X$ & $104-A x$ & |102-AX \\
\hline $\begin{array}{l}\text { Volume } \\
\left(\mathrm{m}^{3}\right)\end{array}$ & 0.04 & 0.02 & 0.02 & 0.08 & 11.36 & 30.28 & 0.002 \\
\hline Date & $2 / 13 / 74$ & $7 / 1 / 66$ & $7 / 1 / 66$ & $1 / 21 / 68$ & $7 / 1 / 68$ & $7 / 1 / 69$ & $12 / 4 / 76$ \\
\hline Material & PSS. & OWW2 & $\operatorname{IIMN}(\mathrm{P} 2)$ & own2 & own3 & IIWW(P2) & B SL/H2O \\
\hline Density & 1.157 & 1.04179 & 1.0459412 & 1.04179 & 1.058684 & 1.0459412 & 1.24409 \\
\hline $\mathrm{Ag}$ & & 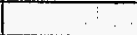 & $\because$ & 0 & & 0 & $\cdot$ \\
\hline $\mathrm{Al}$ & 0.022 & & & 0 & & 0 & 2.324 \\
\hline As & & & : & 0 & & 0 & \\
\hline$B a$ & & & 1 & 0 & & 0 & \\
\hline$B i$ & $\cdot$ & & i & 0 & & 0 & \\
\hline $\mathrm{Ca}$ & & $9.00 \mathrm{e}-03$ & $9.00 \mathrm{e}-03$ & $9.00 \mathrm{e}-03$ & $9.00 \mathrm{e}-03$ & $9.00 \mathrm{e}-03$ & $2.14 e-01$ \\
\hline $\mathrm{Cd}$ & & & & 0 & & 0 & \\
\hline Cl & & 0.00692 & 0.02614008 & 0.00692 & 0.021392 & 0.0261401 & \\
\hline $\mathrm{Cr}$ & & 0.00802 & 0.00806046 & 0.00802 & 0.008018 & 0.0080605 & \\
\hline $\mathrm{Cu}$ & & & $\because$ & 0 & & 0 & \\
\hline$F$ & & & & 0 & & 0 & \\
\hline $\mathrm{Fe}$ & & 0.002 & 0.00200005 & 0.002 & 0.002 & 0.0020001 & 1.000298 \\
\hline $\mathrm{Hg}$ & & & & 0 & & 0 & \\
\hline $\mathrm{K}$ & & 0.01353 & 0.00568263 & 0.01353 & 0.005535 & 0.0056826 & \\
\hline La & & & & 0 & & 0 & \\
\hline $\mathrm{Mg}$ & & & & 0 & & 0 & \\
\hline $\mathrm{Mn}$ & & 0.009 & & 0.009 & 0.000884 & 0 & \\
\hline $\mathrm{Na}$ & 5.111 & 1.12565 & 1.28540407 & 1.12565 & 1.579112 & 1.2854041 & 2.40634 \\
\hline $\mathrm{Ni}$ & & 0.0018 & 0.0018 & 0.0018 & 0.0018 & 0.0018 & 0.040277 \\
\hline $\mathrm{Pb}$ & & & & 0 & & 0 & \\
\hline Se & & & & 0 & & 0 & \\
\hline $\mathrm{Si}$ & $2.78 \mathrm{e}-04$ & & 0.03402903 & 0 & & 0.034029 & 1.20317 \\
\hline Sr & 0.0000023 & 0 & 0.00002 & 0 & 0 & 0.0000172 & 0.0000208 \\
\hline TOC & & 0.27986 & & 0.27986 & 0.22239 & 0 & \\
\hline Total U & 0 & 0.0040394 & 0.0015748 & 0.0040394 & 0.0040104 & 0.0015748 & 0.001065 \\
\hline $\mathrm{Zr}$ & & & & 0 & & 0 & \\
\hline $\mathrm{Zn}$ & & & & 0 & & 0 & \\
\hline$Z_{r}$ & & & & 0 & & 0 & \\
\hline EDTA & & & & 0 & & 0 & \\
\hline $\mathrm{NH}_{3}$ & & & t. & 0 & & 0 & \\
\hline $\mathrm{Cr}^{+6}$ & & & & 0 & & 0 & \\
\hline $\mathrm{T}: \mathrm{C}$ as $\mathrm{CO}_{3}$ & 0.4 & 0.39095 & 0.00900371 & 0.39095 & 0.295646 & 0.0090037 & 0.214419 \\
\hline $\mathrm{CN}$ & & & & $\underline{0}$ & & 0 & \\
\hline
\end{tabular}




\section{Table 2. Contaminant Stream Compositions (page 2 of 2)}

\begin{tabular}{|c|c|c|c|c|c|c|c|}
\hline \multicolumn{3}{|c|}{ 241-AX Farm Release Estimates } & \multicolumn{5}{|c|}{ Concentrations - $\mathrm{mol} / \mathrm{L}$} \\
\hline Region & NW & NC & NC & CNW & C\&CE & C\&SW & $S E$ \\
\hline $\begin{array}{l}\text { Assoc. } \\
\text { Tank }\end{array}$ & $103-A X$ & 103-AX & $103-A x$ & $102-A X$ & $102-A x$ & $104-A x$ & $102-A X$ \\
\hline $\begin{array}{l}\text { Volume } \\
\left(\mathrm{m}^{3}\right)\end{array}$ & 0.04 & 0.02 & 0.02 & 0.08 & 11.36 & 30.28 & 0.002 \\
\hline Date & $13 / 74$ & $7 / 1 / 66$ & $7 / 1 / 66$ & $1 / 21 / 68$ & $7 / 1 / 68$ & $7 / 1 / 69$ & $12 / 4 / 76$ \\
\hline Mater & SS & OWn2 & $\operatorname{IWW}(\mathrm{P} 2)$ & OWn2 & own3. & IUWW(P2) & B SLH 20 \\
\hline $\mathrm{NO}_{3}$ & 0.14 & 0.37839 & 0.1337853 & 0.37839 & 0.944986 & 0.1337 .853 & \\
\hline $\mathrm{NO}_{2}$ & 1.36 & 0.01002 & 0.5 & 0.01002 & 0.010023 & 0.5935814 & \\
\hline $\mathrm{OH}$ & 0.77 & 0.06559 & 74894 & 0.06559 & 0.088134 & 0.1927489 & 1.080852 \\
\hline $\mathrm{Pas} \mathrm{PO}_{4}$ & 0.013 & & & 0 & & 0 & \\
\hline $\mathrm{Sas} \mathrm{SO}_{4}$ & $\begin{array}{r}0.19 \\
\end{array}$ & 0.00401 & 0.15 & 0.00401 & 0.004009 & 0.1599881 & \\
\hline $\mathrm{H}_{2} \mathrm{O}$ & 52.149518 & 53.1716427 & 53.185209 & 53.171643 & 51.980008 & -53.18521 & \\
\hline
\end{tabular}

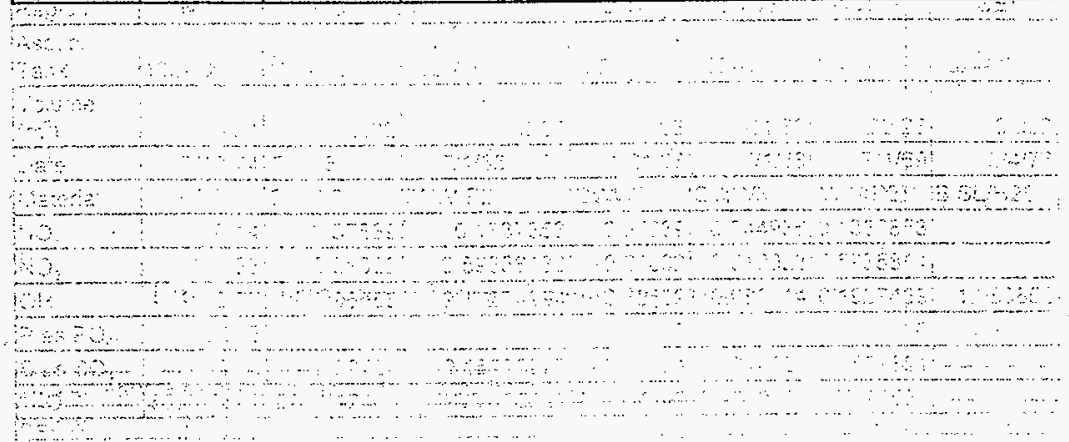


HNF-SD-HTI-TI-001, REV. 0

SESC-EN-RPT-002, Rev. 0

(formally known as)

Table 3. Contaminant Stream Radiological Compositions (page 1 of 2)

\begin{tabular}{|c|c|c|c|c|c|c|c|}
\hline \multicolumn{3}{|c|}{ 241-AX Farm Release Estimates } & \multicolumn{5}{|c|}{ Concentrations - $\mathrm{Ci} / \mathrm{L}$} \\
\hline & NW & NC & NC: $:$ & CNW & C\&CE & C\&SW & SSE \\
\hline & PSS & OWw2 & IiVW(P2) & OWW2 & lown3 & $\operatorname{IWW}(\mathrm{P} 2)$ & $\mathrm{BSL} / \mathrm{H} 2 \mathrm{O}$ \\
\hline Decay & $10 / 15 / 74$ & $1 / 2 / 94$ & $1 / 2 / 94$ & $1 / 2 / 94$ & $1 / 2 / 94$ & $1 / 2 / 94$ & $1 / 2 / 94$ \\
\hline${ }^{3} \mathrm{H}$ & & & 0.0001581 & 0 & & 0.0001581 & 0.0000649 \\
\hline${ }^{14} \mathrm{C}$ & & & $2.95 \mathrm{e}-05$ & 0 & & 0.0000295 & 0.00002 \\
\hline${ }^{60} \mathrm{Co}$ & & & $4.06 \mathrm{e}-05$ & 0 & & 0.0000406 & 0.0000481 \\
\hline${ }^{63} \mathrm{Ni}$. & & & 0.0003663 & 0 & & 0.0003663 & 0.0003679 \\
\hline $7^{9} \mathrm{Se}$ & & & $2 e-06$ & 0 & 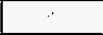 & 0.000002 & 0.0000024 \\
\hline${ }^{00} \mathrm{Sr}$ & 0.0046 & & 0.03400003 & 0 & & 0.034 & 0.0411512 \\
\hline $90 Y$ & 0.0046 &.$\quad 0$ & 0.03400003 & 0 & 0 & 0.034 & 0.0411512 \\
\hline${ }^{93} \mathrm{Zr}$ & & & $1 \mathrm{e}-05$ & 0 & & 0.00001 & 0.0000121 \\
\hline PSTC & & & $\mid 0.00020894$ & 0 & & 0.0002089 & 0.000133 \\
\hline${ }^{126} \mathrm{Sn}$ & & & $3 e-06$ & 0 & & 0.000003 & 0.0000036 \\
\hline 129 & & & $4: 04 \mathrm{e}-07$ & 0 & & 0.0000004 & 0.0000003 \\
\hline${ }^{134} \mathrm{Cs}$ & 0.0358 & & $9.68 \mathrm{e}-06$ & 0 & . & 0.0000097 & 0.0000023 \\
\hline${ }^{135} \mathrm{Cs}$ & & & & 0 & & 0 & \\
\hline${ }^{137} \mathrm{Cs}$ & 2.16 & & 0.77029728 & 0 & & 0.7702973 & 0.0320419 \\
\hline${ }^{137} \mathrm{mBa}$ & 2.04336 & 0 & 0.7287 & 0 & 0 & 0.7287012 & 0.0303116 \\
\hline${ }^{151} \mathrm{Sm}$ & & & 0.00700001 & 0 & & 0.007 & 0.0084723 \\
\hline${ }^{152} \mathrm{Eu}$ & & & $484 e-06$ & 0 & & 0.0000048 & 0.0000065 \\
\hline${ }^{154} \mathrm{Eu}$ & & & 0.0005 & 0 & & 0.0005 & 0.0006052 \\
\hline${ }^{155} \mathrm{Eu}$ & & & 0.00036024 & 0 & & 0.0003602 & 0.0003163 \\
\hline${ }^{228} \mathrm{Ra}$ & & & $6.02 e-09$ & 0 & & $6.020 \mathrm{e}-09$ & $7.504 \mathrm{e}-11$ \\
\hline $227 \mathrm{Ac}$ & & & $3.60 \mathrm{e}-10$ & 0 & & $3.600 e-10$ & $4.357 \mathrm{e}-10$ \\
\hline${ }^{228} \mathrm{Ra}$ & & & $2.55 \mathrm{e}-15$ & 0 & & $2.550 \mathrm{e}-15$ & $2.728 \mathrm{e}-15$ \\
\hline${ }^{229} \mathrm{Th}$ & & & $3.98 \mathrm{e}-13$ & 0 & & $3.980 \mathrm{e}-13$ & $2.560 \mathrm{e}-13$ \\
\hline${ }^{23 i} \mathrm{~Pa}$ & & & $2 \mathrm{e}-09$ & 0 & & $2.000 \mathrm{e}-09$ & $2.421 \mathrm{e}-09$ \\
\hline${ }^{232} \mathrm{Th}$ & & & $7.48 \mathrm{e}-15$ & 0 & & $7.481 \mathrm{e}-15$ & $8.445 \mathrm{e}-15$ \\
\hline${ }^{232} \mathrm{U}$, & & $6.40 \mathrm{e}-08$ & $1.04 \mathrm{e}-11$ & $6.400 \mathrm{e}-08$ & $1.59 \mathrm{e}-06$ & $1.040 \mathrm{e}-11$ & $3.164 e-11$ \\
\hline${ }^{233} \mathrm{U}$ & & $2.50 \mathrm{e}-07$ & $245 \mathrm{e}-13$ & 0.0000002 & $6.09 \mathrm{e}-06$ & $2.452 \mathrm{e}-13$ & $4.183 \mathrm{e}-13$ \\
\hline${ }^{234} \mathrm{U}$ & & $3.30 \mathrm{e}-0.7$ & $128 \mathrm{e}-07$ & 0.0000003 & $4.64 e-07$ & 0.0000001 & 0.0000001 \\
\hline${ }^{235} \mathrm{U}$ & & $1.40 \mathrm{e}-08$ & $5: 35 e-09$ & $1.400 \mathrm{e}-08$ & $1.62 \mathrm{e}-08$ & $5.346 \mathrm{e}-09$ & $4.305 \mathrm{e}-09$ \\
\hline $236 \mathrm{U}$ & & $8.90 \mathrm{e}-0.9$ & $3.50 \mathrm{e}-09$ & $8.900 \mathrm{e}-09$ & $3.25 \mathrm{e}-08$ & $3.497 \mathrm{e}-09$ & $8.628 \mathrm{e}-09$ \\
\hline${ }^{237} \mathrm{~Np}$ & & & $446 \mathrm{e}-07$ & 0 & & 0.0000004 & 0.0000004 \\
\hline${ }^{233} \mathrm{Pu}$ & & & $3.37 \mathrm{e}-07$ & 0 & & 0.0000003 & 0.0000015 \\
\hline${ }^{238} \mathrm{U}$ & & $3.20 \mathrm{e}-0.7$ & $1: 25 \mathrm{e}-07$ & 0.0000003 & $3.17 e-07$ & 0.0000001 & $8.424 \mathrm{e}-08$ \\
\hline${ }^{239} \mathrm{Pu}$ & & & $8.73 e-06$ & 0 & & 0.0000087 & 0.0000101 \\
\hline${ }^{240} \mathrm{Pu}$ & & & $167 e-06$ & 0 & & 0.0000017 & 0.0000036 \\
\hline${ }^{241} \mathrm{Am}$ & & & 0.00003 & 0 & & 0.00003 & 0.0000363 \\
\hline${ }^{242} \mathrm{Cm}$ & & & $1.34 \mathrm{e}-07$ & 0 & & 0.0000001 & 0.0000006 \\
\hline
\end{tabular}




\section{HNF-SD-HTI-TI-001, REV. 0 \\ SESC-EN-RPT-002, Rev. 0 \\ (formally known as) \\ Table 3. Contaminant Stream Radiological Compositions (page 2 of 2)}

\begin{tabular}{|l|l|l|l|l|l|l|l|}
\hline $241-A X$ Farm Release Estimates & \multicolumn{5}{l|}{ Concentrations - Ci /L } \\
\hline & NW & NC & NC & CNW & C\&CE & C\&SW & SE \\
\hline & PSS & OWW2 & IWW(P2) & OWW2 & OWW3 & WW(P2) & B SLH20 \\
\hline Decay & $10 / 15 / 74$ & $1 / 2 / 94$ & $1 / 2 / 94$ & $1 / 2 / 94$ & $1 / 2 / 94$ & $1 / 2 / 94$ & $1 / 2 / 94$ \\
\hline${ }^{242} \mathrm{mAm}$ & & & & 0 & & 0 & \\
\hline${ }^{243} \mathrm{Am}$ & & & $9.20 \mathrm{e}-10$ & 0 & & $9.203 \mathrm{e}-10$ & 0.0000649 \\
\hline${ }^{243} \mathrm{Cm}$ & & & $1.03 \mathrm{e}-08$ & 0 & $\ddots$ & $1.027 \mathrm{e}-08$ & $4.061 \mathrm{e}-09$ \\
\hline${ }^{244} \mathrm{Cm}$ & & & $1 \mathrm{e}-07$ & 0 & & 0.0000001 & 0.0000001 \\
\hline
\end{tabular}

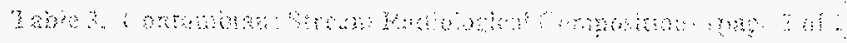

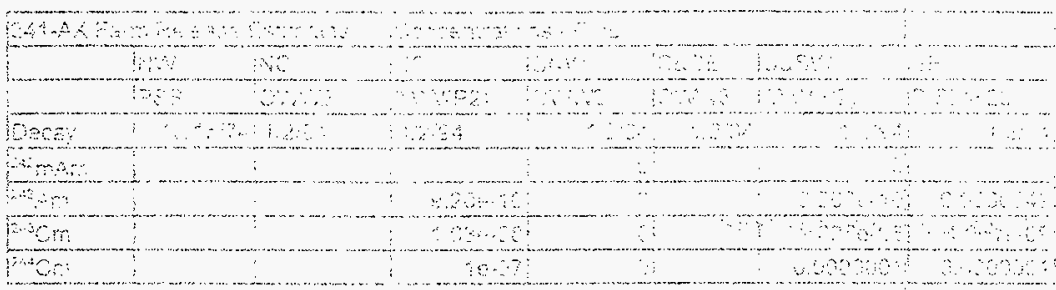


Table 4. 241-AX Farm Chemical Release Inventory Estimate (page 1 of 2)

\begin{tabular}{|c|c|c|c|c|c|c|c|}
\hline \multicolumn{5}{|c|}{ 241-AX Farm Release Estimates } & \multicolumn{3}{|l|}{ Inventory $\mathrm{kg}$} \\
\hline Region & NWW & NC & CNW & $\mathrm{C} \& \mathrm{CE}$ & C\&SW & $S E$ & Total \\
\hline \begin{tabular}{|l} 
Assoc. \\
Tank \\
\end{tabular} & $103-A x$ & $103-A x$ & $102-A x$ & $102-A X$ & 104-AX & $102-\mathrm{AX}$ & \\
\hline $\begin{array}{l}\text { Volume } \\
\left(\mathrm{m}^{3}\right)\end{array}$ & 0.0400335 & 0.04 & 0.08 & 11.35599 & 30.28264 & 0.002 & \\
\hline Date & $02 / 12 / 74$ & $.06 / 30 / 66$ & $01 / 20 / 68$ & $06 / 30 / 68$ & $06 / 30 / 69$ & $12 / 03 / 76$ & \\
\hline Material & PSS & $\begin{array}{l}\text { OWWW2IW } \\
\dot{w}(\mathrm{P} 2)\end{array}$ & own2 & own3 & $\operatorname{INW}(\mathrm{P} 2)$ & $\mathrm{B}$ SL/H2O & \\
\hline $\mathrm{Ag}$ & $\mathrm{NR}^{1}$ & INR & NR & NR & NR & NR & NR \\
\hline Al & $2.38 \mathrm{e}-02$ & NR & NR & NR & NRR & $1.25 \mathrm{e}-01$ & $1.49 \mathrm{e}-01$ \\
\hline As & NR & NR & NR & NR & NR & NR & NR \\
\hline $\mathrm{Ba}$ & NR & NR & NR & NR & NR & NR. & NR. \\
\hline Bi. & NR: & NR. & NR. & NR. & NR & NR & NR \\
\hline $\mathrm{Ca}$ & NR & $1.44 \mathrm{e}-02$ & $2.89 \mathrm{e}-02$ & $4.10 e+00$ & $1.09 e+01$ & $1.72 \mathrm{e}-02$ & $1.51 e+01$ \\
\hline Cd & NR & INR & NR: & NR & NR & NR & NR \\
\hline Cl.......... & NR & $2.37 \mathrm{e}-02$ & $1.96 \mathrm{e}-02$ & $8.61 e+00$ & $2.81 e+01$ & NR - & $3.67 e+01$ \\
\hline $\mathrm{Cr}$ & NR & $1.67 \mathrm{e}-02$ & $3.34 \mathrm{e}-02$ & $4.73 e+00$ & $1.27 e+01$ & NR & $1.75 e+01$ \\
\hline $\mathrm{Cu}$ & NR: & NR & NR: & NR & NR: & NR & NR \\
\hline F & NR & NR & NR & NR & INR & NR & NR \\
\hline $\mathrm{Fe}$ & NR & $4.47 \mathrm{e}-03$ & $8.94 \mathrm{e}-03$ & $1.27 \mathrm{e}+00$ & $3.38 e+00$ & $1.12 e-01$ & $4.78 \mathrm{e}+00$ \\
\hline $\mathrm{Hg}$ & NRR & NR & NR & NR & INR & NR & NR \\
\hline $\mathrm{K}$ & NR & $1.49 \mathrm{e}-02$ & $4.24 \mathrm{e}-02$ & $2.46 e+00$ & $6.73 e+00$ & NR & $9.24 \mathrm{e}+00$ \\
\hline Là & NR & NR & NR & NR & INR & NR & NR \\
\hline $\mathrm{Mg}$ & NRR & NR & NR & NR & INR & NR & NR \\
\hline $\mathrm{Mn}$ & NR & $9.67 \mathrm{e}-03$ & $3.96 \mathrm{e}-02$ & $5.52 \mathrm{e}-01$ & NR & NR & $0.01 e-01$ \\
\hline $\mathrm{Nä}$ & $4.70 e+00$ & $1.11 \mathrm{e}+00$ & $2.07 e+\infty$ & $4.12 e+02$ & $8.95 \mathrm{e}+02$ & $1.11 \mathrm{e}-01$ & $1.32 e+03$ \\
\hline $\mathrm{Ni}$ & NR & $4.23 \mathrm{e}-0,3$ & $8.46 \mathrm{e}-03$ & $1.20 \mathrm{e}+00$ & $3.20 e+00$ & $4.73 \mathrm{e}-03$ & $4.42 e+00$ \\
\hline $\mathrm{Pb}$ & NR & NR & NR & NR & NR & NR & NR \\
\hline Se & NR & NR & NR & NR & NR & NR & NR \\
\hline$S i$ & $3.13 \mathrm{e}-04$ & $1.95 \mathrm{e}-0.2$ & NR & NR & $2.89 \mathrm{e}+01$ & $6.76 \mathrm{e}-02$ & $2.90 \mathrm{e}+01$ \\
\hline $\mathrm{Si}$ & $8.17 e-06$ & $3.08 e-0.5$ & NR & NR & $4.57 \mathrm{e}-02$ & $3.65 \mathrm{e}-06$ & $4.57 \mathrm{e}-02$ \\
\hline TOC & NR & $6.57 e-0.2$ & $2.69 e-01$ & $3.03 e+01$ & NR & INR & $3.07 e+01$ \\
\hline Total U & NR & $2.65 \mathrm{e}-0.2$ & $7,70 \mathrm{e}-02$ & $1.08 e+01$ & $1.14 \mathrm{e}+01$ & $5.07 e-04$ & $2.23 e+01$ \\
\hline $\mathrm{Zr}$ & NR & NR & NR & INR & NR & NR & NR \\
\hline $\mathrm{Zn}$ & NR & NR & NRR & NR & NR & NR & NR \\
\hline $\mathrm{Zr}$ & NR & NR & NRR & NR & NR & NR & NR. \\
\hline EDTA & NR & NR & NR & NR & INR & NR & NR \\
\hline $\mathrm{NH}_{3}$ & NR & NR & INR & NRR & INR & INR & NR \\
\hline
\end{tabular}

NR [ $]$. Not Reported. 
Table 4. 241-AX Farm Chemical Release Inventory Estimate (page 2 of 2)

\begin{tabular}{|c|c|c|c|c|c|c|c|}
\hline \multicolumn{5}{|c|}{ 241-AX Farm Release Estimates } & \multicolumn{3}{|l|}{ Inventory $\mathrm{kg}$} \\
\hline Region & NW & INC & CNW. & C\&CE & C\&SW & SE & Total \\
\hline \begin{tabular}{|l} 
Assoc. \\
Tank \\
\end{tabular} & 3-AX & $103-A x$ & $102-A X$ & $102-A X$ & 104-AX & $102-A x$ & \\
\hline $\begin{array}{l}\text { Volume } \\
\left(\mathrm{m}^{3}\right) \\
\end{array}$ & 0.0400335 & 0.04 & 0.08 & 11.35599 & 30.28264 & 0.002 & \\
\hline Date & $2 / 12 / 74$ & $06 / 30 / 66$ & $01 / 20 / 68$ & $06 / 30 / 68$ & $06 / 30 / 69$ & $12 / 03 / 76$ & \\
\hline Material & PSS & $\begin{array}{l}\text { OWW2IW } \\
\text { W(P2) }\end{array}$ & OWW2 & lown3 & IWW(P2) & B SL/H2O & \\
\hline $\mathrm{Cr}^{+6}$ & NR & NRR & NR & NR & NR & NRR & NR \\
\hline TIC as $\mathrm{CO}_{3}$ & $9.61 \mathrm{e}-01$ & $4.70 \mathrm{e}-01$ & $1.88 \mathrm{e}+00$ & $2.01 \mathrm{e}+02$ & $1.64 \mathrm{e}+01$ & $2.57 \mathrm{e}-02$ & 2.2 \\
\hline $\mathrm{CN}$ & NR & NRR & INR & NR & NR & NR & NR \\
\hline $\mathrm{NO}_{3}$ & $.3 .48 \mathrm{e}-01$ & $6.28 \mathrm{e}-01$ & $1.88 \mathrm{e}+00$ & $6.65 \mathrm{e}+02$ & $2.51 \mathrm{e}+02$ & NR & +02 \\
\hline $\mathrm{NO}_{2}$ & $2.50 \mathrm{e} \pm 00$ & $5.67 \mathrm{e}-01$ & $3.69 \mathrm{e}-02$ & $5.24 \mathrm{e} \pm 00$ & $8.27 e+02$ & $\mid \mathrm{NR}$ & $8.35 e+02$ \\
\hline OH & $5.24 e-0.1$ & $8.88 \mathrm{e}-02$ & $8.93 \mathrm{e}-02$ & $1.70 \mathrm{e}+0.1$ & $9.93 e+01$ & $3.68 \mathrm{e}-02$ & $1.17 e+02$ \\
\hline Pasp & $4.94 \mathrm{e}-02$ & NR & NR & NR & INR & NRR & $4.94 \mathrm{e}-02$ \\
\hline $\mathrm{S}$ as $\mathrm{SO}_{4}$ & $7.31 \mathrm{e}-01$ & $3.22 \mathrm{e}-01$ & $3.08 \mathrm{e}-02$ & $4.37 \mathrm{e}+00$ & $465 \mathrm{e}+02$ & NR: & $4.7 \cdot 1 e+02$ \\
\hline $\mathrm{H}_{2} \mathrm{O}$ & $3.76 e+01$ & $3.83 e+01$ & $7.67 e+0.1$ & $1.06 e+04$ & $2.90 \mathrm{e}+04$ & ANR & $3.98 e+04$ \\
\hline
\end{tabular}


Table 5. 241-AX Release Radiological Inventory (page 1 of 2)

\begin{tabular}{|c|c|c|c|c|c|c|c|}
\hline \multicolumn{4}{|c|}{ 241-AX Farm Release Estimates } & \multicolumn{4}{|c|}{ Inventory (Ci) } \\
\hline & NW & NC & $\mathrm{CSW}$ & C\&CE & CNW & SE & Total \\
\hline & PSS & $\begin{array}{l}\text { OWW2 } \\
\text { IWW(P2) }\end{array}$ & OWW2 & OWW 3 & IWW(P2) & $\mathrm{B} \mathrm{SL} / \mathrm{H} 2 \mathrm{O}$ & \\
\hline Decay & $12 / 31 / 99$ & 12/31/99 & $12 / 31 / 99$ & $12 / 31 / 99$ & $12 / 31 / 99$ & $12 / 31 / 99$ & $12 / 31 / 99$ \\
\hline${ }^{3} \mathrm{H}$ & NR & $2.31 e-03$ & NR & NR & $3.42 e+00$ & $9.28 \mathrm{e}-05$ & $3.42 e+00$ \\
\hline${ }^{14} \mathrm{C}$ & NR & $4.30 \mathrm{e}-0.4$ & NR & NR & $6.38 \mathrm{e}-01$ & $2.86 \mathrm{e}-05$ & $6.38 \mathrm{e}-01$ \\
\hline${ }^{60} \mathrm{Co}$ & NR & $5.93 \mathrm{e}-04$ & NR & NR & $8.79 \mathrm{e}-01$ & $6.88 \mathrm{e}-05$ & $8.79 \mathrm{e}-01$ \\
\hline${ }^{63} \mathrm{Ni}$ & NR & $5.35 \mathrm{e}-03$ & NR & NR & $7.93 e+00$ & $5.26 e-04$ & $7.93 e+00$ \\
\hline${ }^{79} \mathrm{Se}$ & NR & $2.92 e-05$ & NR & NR & $4.33 \mathrm{e}-02$ & $3.46 e-06$ & $4.33 e-02$ \\
\hline${ }^{90} \mathrm{Sr}$ & $4.48 \mathrm{e}-02$ & $4.97 \mathrm{e}-01$ & NR & NR & $7.36 e+02$ & $5.88 \mathrm{e}-02$ & $7.36 \mathrm{e}+02$ \\
\hline${ }^{90} \mathrm{Y}$ & $4.48 \mathrm{e}-02$ & $4.97 \mathrm{e}-01$ & NR & NR & $7.36 e+02$ & $5.88 \mathrm{e}-02$ & $7.36 \mathrm{e}+02$ \\
\hline${ }^{93} \mathrm{Zr}$ & NR & $1.46 \mathrm{e}=04$ & NR & NR & $2: 16 \mathrm{e}-01$ & $1.73 e-05$ & 2.17e-01 \\
\hline $99 \mathrm{Tc}$ & $\mathrm{NR}$ & $3.05 \mathrm{e}-03$ & NR & NR & $4.52 e+00$ & e-04 & $2 e+00$ \\
\hline${ }^{126} \mathrm{Sn}-\cdots$ & NR & $438 \mathrm{e}=0.5$ & . n........... & $\overline{\mathrm{NR}}$ & $6.49 \mathrm{e}-02$ & $5: 1$ & $0=02$ \\
\hline 129 & NR: & $5.90 e-06$ & NR & NR: & $8.75 \mathrm{e}-03$ & $3.70 \mathrm{e}-07$ & $8.75 \mathrm{e}-03$ \\
\hline${ }^{134} \mathrm{Cs}$ & $3.49 \mathrm{e}-01$ & $1.41 \mathrm{e}-04$ & $\mathrm{NR}$ & NR & $e-01$ & $3.31 \mathrm{e}-06$ & $2-01$ \\
\hline${ }^{135} \mathrm{Cs}$ & NR & NR & $\mathrm{NR}$ & NR & NR: & NR & NR \\
\hline${ }^{437} \mathrm{Cs}$ & $2.10 e+01$ & $e+01$ & $\mathrm{NR}$ & NR & $1.67 e+04$ & 02 & $7 e+04$ \\
\hline${ }^{137} \mathrm{mBa}$ & $1.99 \mathrm{e}+01$ & $1.06 \mathrm{e}+01$ & $\mathrm{NR}$ & NR & $1.58 \mathrm{e}+04$ & $4.33 e-02$ & $1.58 e+04$ \\
\hline $151 \mathrm{Sm}$ & $N R$ & $e-01$ & $\mathrm{NR}$ & NR & +02 & -02 & $2 e+02$ \\
\hline${ }^{152} \mathrm{Eu}$ & NR & $7.06 e-05$ & $\mathrm{NR}$ & $\mathrm{NR}$ & $0-01$ & -06 & $e-01$ \\
\hline${ }^{154} \mathrm{Eu}$ & NR & $e-03$ & NR & NR & $e+01$ & -04 & $3 e+01$ \\
\hline${ }^{155} \mathrm{Eu}$ & NR & $5.26 \mathrm{e}-03$ & NR & NR & $7.79 e+00$ & $4.52 \mathrm{e}-04$ & $7.80 \mathrm{e}+00$ \\
\hline${ }^{226} \mathrm{Ra}$ & NR & $8.79 \mathrm{e}-08$ & NR & NR & $1.30 \mathrm{e}-04$ & $1.07 \mathrm{e}-10$ & $0 \mathrm{e}-04$ \\
\hline${ }^{227} \mathrm{AC}$ & $\mathrm{NR}^{\mathrm{K}}$ & $5.26 \mathrm{e}-09$ & NR & NR. & -06 & $6.23 \mathrm{e}-10$ & $2-06$ \\
\hline${ }^{228} \mathrm{Ra}$ & INR & $372 \mathrm{e}-14$ & NNA & $\mathrm{NR}$ & $5.52 \mathrm{e}-11$ & $e-15$ & $2 e-1.1$ \\
\hline $229 \mathrm{Th}$ & $N R$ & $5.81 \mathrm{e}-12$ & $\mathrm{NR}$ & $\mathrm{NR}$ & $8.61 \mathrm{e}-09$ & $3.66 \mathrm{e}-13$ & $62 \mathrm{e}-09$ \\
\hline $23 \mathrm{~Pa}$ & NR: & $2.92 e-08$ & $\mathrm{NR}$ & NR & $4.33 \mathrm{e}-05$ & $-3.46 \mathrm{e}-09$ & $4.33 \mathrm{e}-05$ \\
\hline${ }^{233} \mathrm{Th}$ & NR: & $1.09 \mathrm{e}-13$ & $\mathrm{NR}$ & NR & $1.62 \mathrm{e}-10$ & $1: 21 \mathrm{e}-14$ & $2 \mathrm{e}-10$ \\
\hline${ }^{323} \mathrm{U}$ & $\mathrm{NR}$ & $8.95 \mathrm{e}-07$ & $1 \quad 3.66 \mathrm{e}-06$ & $1.29 \mathrm{e}-02$ & $2.25 \mathrm{e}-07$ & $4.52 e-11$ & $9 e-02$ \\
\hline${ }^{233} \mathrm{U}$ & NR & $3: 49 \mathrm{e}-06$ & $1.43 e-05$ & $4.94 e-02$ & $5.31 \mathrm{e}-09$ & $5.98 e-13$ & $4.94 e-02$ \\
\hline${ }^{234} \mathrm{U}$ & NR * & $6.48 \mathrm{e}-06$ & $1: 89 e-05$ & $3.76 e-03$ & $277 \mathrm{e}-03$ & $1.60 \mathrm{e}-07$ & $6.56 \mathrm{e}-03$ \\
\hline${ }^{235} \mathrm{U}$ & NR . & $2.74 \mathrm{e}-07$ & $8.01 e-07$ & $1.31 \mathrm{e}-04$ & $1.16 \mathrm{e}-04$ & $6.15 \mathrm{e}-09$ & $8 \mathrm{e}-04$ \\
\hline${ }^{236} \mathrm{U}$ & NR & $1.75 \mathrm{e}-07$ & 5.09e-07 & $2.64 e-04$ & $7.57 \mathrm{e}-05$ & $1.23 \mathrm{e}-08$ & $3.40 \mathrm{e}-04$ \\
\hline${ }^{237} \mathrm{~Np}$ & NR & $6.52 \mathrm{e}-06$ & NR & NR & $9.66 \mathrm{e}-03$ & $6.11 \mathrm{e}-07$ & $9.67 e-03$ \\
\hline${ }^{238} \mathrm{Pu}$ & $\mathrm{NR}$ & $4.92 \mathrm{e}-06$ & $\mathrm{NR}$ & NR & $7.29 \mathrm{e}-03$ & $2.13 \mathrm{e}-06$ & $7.30 \mathrm{e}-03$ \\
\hline 2380 & $N R$ & $6.29 \mathrm{e}-06$ & $183 \mathrm{e}-05$ & $2.57 \mathrm{e}-03$ & $2.70 \mathrm{e}-03$ & $1.20 e-07$ & $5.30 e-03$ \\
\hline${ }^{239} \mathrm{Pe}$ & NR & $127 \mathrm{e} 04$ & $\mathrm{NR}$ & NR & $1: 89 e-01$ & $144 \mathrm{e}-05$ & $1.89 \mathrm{e}-01$ \\
\hline${ }^{240} \mathrm{PH}$ & $N R$ & $2.43 \mathrm{e}-05$ & NR & NR & $3.60 \mathrm{e}-02$ & $5.18 \mathrm{e}-06$ & $3.61 \mathrm{e} 02$ \\
\hline $247 \mathrm{Am}$ & NR & $4.38 \mathrm{e}-04$ & NR: & NR & $6.49 \mathrm{e}-01$ & $5.19 \mathrm{e}-05$ & $6.50 \mathrm{e}-01$ \\
\hline${ }^{242} \mathrm{Cm}$ & INR & $1.95 \mathrm{e}-06$ & NR & $\mathrm{NR}$ & $2.89 \mathrm{e}-03$ & $8.05 \mathrm{e}-07$ & $2.89 \mathrm{e}-03$ \\
\hline
\end{tabular}


Table 5. 241-AX Release Radiological Inventory (page 2 of 2)

\begin{tabular}{|c|c|c|c|c|c|c|c|}
\hline${ }^{242} \mathrm{mAm}$ & NR & NR & NR & NR & NR & NR & NR \\
\hline${ }^{243} \mathrm{Am}$ & NR & $1.34 \mathrm{e}-08$ & NR & NR & $1.99 e-05$ & $9.28 \mathrm{e}-05$ & $1.13 e-04$ \\
\hline${ }^{243} \mathrm{Cm}$ & NR & $1.50 \mathrm{e}-07$ & $N R$ & NR & $2.22 e-04$ & $5.80 \mathrm{e}-09$ & $2.22 e-04$ \\
\hline${ }^{244} \mathrm{Cm}$ & NR & $1.46 \mathrm{e}-06$ & NR & NR & $2.16 \mathrm{e}-03$ & $1.73 e-07$ & $2.17 \mathrm{e}-03$ \\
\hline
\end{tabular}

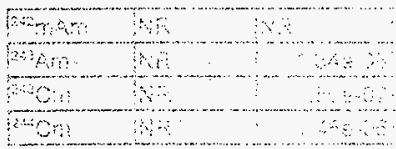


Table 6. Estimated Volume of Contamination in 241-AX Tank Farm

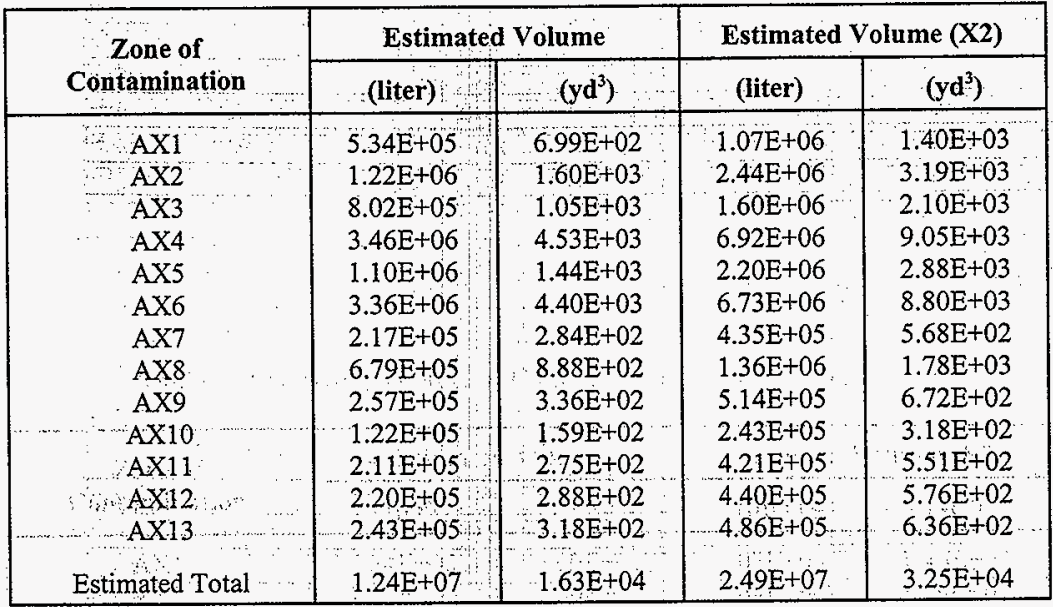


HNF-SD-HTI-TI-001, REV. 0

SESC-EN-RPT-002, Rev. 0

(formally known as)

Table 7. Radionuclide Concentrations of Zones of Contamination

\begin{tabular}{|c|c|c|c|}
\hline $\begin{array}{c}\text { Zone of } \\
\text { Contamination }\end{array}$ & $\begin{array}{l}\text { Concentration } \\
\quad(\mathrm{pCi} / \mathrm{g})\end{array}$ & $\begin{array}{c}\text { Man-Made } \\
\text { Radionuclides } \\
\text { Detected }\end{array}$ & $\begin{array}{l}\text { Location of Peak } \\
\text { Concentrations }\end{array}$ \\
\hline $\begin{array}{l}\text { AX1 } \\
\text { AX2 } \\
\text { AX3 } \\
\text { AX4 } \\
\text { AX5 } \\
\text { AX6 } \\
\text { AX7 } \\
\text { AX8 } \\
\text { AX9 } \\
\text { AX10 } \\
\text { AXX11: } \\
\text { AX13 }\end{array}$ & $\begin{array}{c}40 \\
100 \\
34 \\
4,000 \\
417 \\
16 \\
8 \\
1,456 \\
8 \\
6 \\
52 \\
13 \\
10\end{array}$ & $\begin{array}{c}{ }^{137} \mathrm{Cs},{ }^{60} \mathrm{Co},{ }^{125} \mathrm{Sb} \\
{ }^{137} \mathrm{Cs},{ }^{60} \mathrm{Co},{ }^{125} \mathrm{Sb} \\
{ }^{137} \mathrm{Cs} \\
{ }^{137} \mathrm{Cs},{ }^{60} \mathrm{Co},{ }^{154} \mathrm{Eu},{ }^{125} \mathrm{Sb} \\
{ }^{137} \mathrm{Cs},{ }^{60} \mathrm{Co},{ }^{154} \mathrm{Eu},{ }^{125} \mathrm{Sb} \\
{ }^{137} \mathrm{Cs},{ }^{60} \mathrm{Co} \\
{ }^{137} \mathrm{Cs} \\
{ }^{137} \mathrm{Cs},{ }^{60} \mathrm{Co},{ }^{137} \mathrm{Eu} \\
{ }^{137} \mathrm{Cs} \\
{ }^{137} \mathrm{Cs} \\
{ }^{137} \mathrm{Cs} \\
{ }^{137} \mathrm{Cs}\end{array}$ & $\begin{array}{l}0 \text { to } 15 \mathrm{ft} \\
0 \text { to } 10 \mathrm{ft} \\
0 \text { to } 5 \mathrm{ft} \\
0 \text { to } 25 \mathrm{ft} \\
0 \text { to } 15 \mathrm{ft} \\
0 \text { to } 10 \mathrm{ft} \\
0 \text { to } 5 \mathrm{ft} \\
0 \text { to } 10 \mathrm{ft} \\
0 \text { to } 5 \mathrm{ft} \\
0 \text { to } 5 \mathrm{ft} \\
0 \text { to } 5 \mathrm{ft} \\
0 \text { to } 5 \mathrm{ft} \\
0 \text { to } 5 \mathrm{ft}\end{array}$ \\
\hline 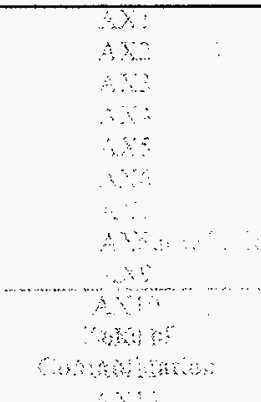 & $\therefore \quad \cdots$ & $\begin{array}{c}\square \\
\therefore\end{array}$ & $\begin{array}{l} \\
\therefore \\
\therefore\end{array}$ \\
\hline
\end{tabular}


HNF-SD-HTI-TI-001, REV. 0

SESC-EN-RPT-002, Rev. 0

(formally known as)

Table 8. 241-AX Tank Farm Release Radiological Inventory

\begin{tabular}{|c|c|c|c|c|c|c|}
\hline \multirow[b]{2}{*}{ Transuranics } & \multicolumn{6}{|c|}{ Zones of Contamination } \\
\hline & $\begin{array}{l}\mathbf{A X 1} \\
(\mathbf{C i})\end{array}$ & $\begin{array}{l}A \times 2 \\
(\mathbf{C i})\end{array}$ & $\begin{array}{l}\mathbf{A X 3} \\
(\mathrm{Ci})\end{array}$ & $\begin{array}{l}\mathrm{AX} 4 \\
(\mathrm{Ci})\end{array}$ & $\begin{array}{l}\text { AX5 } \\
\text { (Ci) }\end{array}$ & $\begin{array}{l}\text { AX6 } \\
(\mathrm{Ci})\end{array}$ \\
\hline${ }^{237} \mathrm{~Np}$ & $\mathrm{NR}$ & $9.66 \mathrm{E}+-$ & NR & $6.52 \mathrm{E}-06$ & NR & $6.11 \mathrm{E}-04$ \\
\hline${ }^{238} \mathrm{Pu}$ & NR & 03 & NR & $4.92 \mathrm{E}-06$ & NR & $2.13 \mathrm{E}-06$ \\
\hline${ }^{240} \mathrm{Pu}$ & NR & $7.29 \mathrm{E}-03$ & $\mathrm{NR}$ & $2.43 \mathrm{E}-05$ & NR & $5.18 \mathrm{E}-06$ \\
\hline${ }^{241} \mathrm{Am}$ & NR & $3.60 \mathrm{E}-02$ & NR & $4.38 \mathrm{E}-04$ & NR & $5.19 \mathrm{E}-05$ \\
\hline${ }^{243} \mathrm{mAM}$ & NR & $6.49 \mathrm{E}-01$ & NR & NR & NR & NR \\
\hline${ }^{243} \mathrm{Am}$ & NR & NR & NR & $1.34 \mathrm{E}-08$ & NR & $9.28 \mathrm{E}-05$ \\
\hline${ }^{243} \mathrm{Cm}$ & NR. & $\begin{array}{l}1.99 \mathrm{E}-05 \\
2.22 \mathrm{E}-04\end{array}$ & NR & $1.50 \mathrm{E}-07$ & NR: & $5.80 \mathrm{E}-09$ \\
\hline $\begin{array}{l}\text { Estimated Total } \\
\text { TRU (Ci) }\end{array}$ & NR & $7.02 \mathrm{E}-01$ & $\mathrm{NR}$ & $4.74 \mathrm{E}-04$ & NR & $7.62 \mathrm{E}-04$ \\
\hline
\end{tabular}

NR-..not recorded 
VOLUME COMPUTATIONS 


\section{VOLUME COMPUTATIONS}

UPPER SURFACE

Grid File: C:/AXTF/AX1/AX1.GRD

Rows: 0 to 32766 .

Cols: 0 to 32766

Grid size as read: $\quad 50$,cols by 50 rows

Delta X: $\quad 1.22449$

Delta Y: $\quad 0.816327$

$X$-Range: $\quad 555$ to 615

Y-Range: 751 to 791

Z-Range: $\quad-22.7541$ to 0.875335

\section{LOWER SURFACE}

Level Surface defined by $Z=0$

VOLUMES

Approximated Volume by

Trapezoidal Rule: $\quad-18861.3$

Simpson's Rule: $\quad-18873.5$

Simpson's 3/8 Rule: -18868.8

CUT \& FILL VOLUMES

Positive Volume [Cuts]: $\quad 85.4335$

Negative Volume [Fills]: $\quad 18946.7$

Cuts minus Fills: $\quad-18861.3$

\section{AREAS}

Positive Planar Area

(Upper above Lower):

Negative Planar Area

(Lower above Upper):

Blanked Planar Area: 0

Total Planar Area: $\quad 2400$

Positive Surface Area

(Upper above Lower):

Negative Surface Area.

(Lower above Upper): 


\section{VOLUME COMPUTATIONS}

UPPER SURFACE .

Grid File: C:/AXTF/AX2/AX2.GRD

Rows: 0 to 32766

Cols: 0 to 32766

Grid size as read: $\quad 50$ cols by 50 rows

Delta X: $\quad 1.63265$

Delta Y: . 1.22449

$X$-Range: $\quad 525$ to 605

Y-Range: $\quad 650$ to 710

Z-Range: $\quad-33.1141$ to 0.973262

\section{LOWER SURFACE}

Level Surface defined by $Z=0$

ism:

\section{VOLUMES}

Approximated Volume by

Trapezoidal Rule: $\quad-43100$

Simpson's Rule: $\quad-\quad-43118.2$

Simpson's 3/8 Rule: -43132.8

CUT \& FIL YOLUMES

Positive Volume [Cuts]: $\quad 536.881$

Negative Volume [Fills]: $\quad 43636.9$

Cuts minus Fills: $\quad-43100$

\section{AREAS}

Positive Planar Area

(Upper above Lower):

1503.38

Negative Planar Area

(Lower above Upper):

Blanked Planar Area: 0

Total Planar Area: $\quad 4800$

Positive Surface Area

(Upper above Lower):

Negative Surface Area

(Lower above Upper):

3296.62

\section{s}

t

FAtt-3

1528.96

6209.35 


\section{VOLUME COMPUTATIONS}

UPPER SURFACE

Grid File:

C:/AXTF/AX3/AX3.GRD

Rows: 0 to 32766

Cols: 0 to 32766

Grid size as read: $\quad 50$ cols by 50 rows

Delta X: $\quad 1: 42857$

Delta Y: $\quad 1.42857$

X-Range: $\quad 565$ to 635

Y-Range: $\quad 560$ to 630

Z-Range: $\quad-\quad 32.2984$ to 1.15128

LOWER SURFACE

Level Surface defined by $Z=0$

VOLUMES

Approximated Volume by

Trapezoidal Rule: $\quad-28312.9$

Simpson's Rule: $\quad-28314.7$

Simpson's 3/8 Rule: $\mathbf{- 2 8 3 1 3 . 7}$

CUT \& FILL VOLUMES

Positive Volume [Cuts]: $\quad 443.22$

Negative Volume [Fills]: 28756.1

Cuts minus Fills: - $\quad-28312.9$

AREAS

Positive Planar Area

(Upper above Lower):

Negative Planar Area

(Lower above Upper):

Blanked Planar Area: 0

Total Planar Area: $\quad 4900$

Positive Surface Area

(Upper above Lower):

Negative Surface Area

(Lower above Upper): 


\section{VOLUME COMPUTATIONS}

UPPER SURFACE

Grid File: C:/AXTF/AX3/AX3.GRD

Rows: 0 to 32766

Cols: 0 to 32766

Grid size as read: $\quad 50$ cols by 50 rows

Delta X: $\quad 1.42857$

. Delta Y: $\quad 1.42857$

X-Range: $\quad 565$ to 635

Y-Range: $\quad 560$ to 630

Z-Range: $\quad-32.2984$ to 1.15128

\section{LOWER SURFACE}

Level Surface defined by $Z=0$

MES

Approximated yolume by

Trapezoidal Rule: $\quad-28312.9$

Simpson's Rule: , 28314.7

Simpson's 3/8 Rule ,-28313.7

CUT \& FILL VOLUMES

Positive Volume [Cuts]: $\quad 443.22$

Negative Volume [Fills]: $\quad 28756.1$

Cuts minus Fills: $\quad-28312.9$

AREAS

Positive Planar Area

(Upperabove Lower)

Negative Planar Area

(Towerabove Upper)

Blanked Planar Area: 0

Total Planar Area: 4900

Positive Surface Area

(Upperabove Lower):

1708.16

Negative Surface Area

(Lower above Upper):

.1721 .8

4975.51 
VOLUME COMPUTATIONS

UPPER SURFACE

Grid File: C:/AXTF/AX5/AX5.GRD

Rows: 0 to 32766

Cols: 0 to 32766

Grid size as read: 50 cols by 50 rows

Delta X: $\quad 1.42857$

Delta Y: $\quad 1.42857$

$X$-Range: $\quad 455$ to 525

Y-Range: $\quad 640$ to 710

Z-Range: $\quad-73.9561$ to 1.29546

LOWER-SURFACE

Level. Surface defined by $Z=0$

VOLUMES

Approximated Volume by

Trapezoidal Rule: $\quad-38899.4$

Simpson's Rule: $\quad-38908.9$

Simpson's 3/8 Rule: -38911.5

CUT \& FILT VOLUMES

Positive Volume [Cuts]: $\quad 569.429$

Negative Volume [Fills]: $\quad 39468.8$

Cuts minus Filis: $\quad-38899.4$

AREAS

Positive Planar Area

(Upper above Lower):

Negative Planar Area

(Lower above Upper):

Blanked Planar Area: 0

Total Planar Area: 4900

Positive Surface Area

(Upper above Lower):

Negative Surface Area

(Lower above Upper): 


\section{VOLUME COMPUTATIONS}

UPPER SURFACE

Grid File: C:/AXTF/AX6/AX6.GRD

Rows: 0 to 32766

Cols: 0 to 32766

Grid size as read: $\quad 50$ cols by 50 rows

Delta X: $\quad 1.42857$

Delta Y: $\quad 2.85714$

$X$-Range: $\quad 405$ to 475

Y-Range: $\quad 560$ to 700

Z-Range: - $\quad-74.4226$ to 2.52762

\section{LOWER SURFACE}

Level Surface defined by $Z=0$

VOLUMES

Approximated Volume by

Trapezoidal Rule: $\quad-118778$

Simpson's Rule: $\quad-118809$

Simpson's 3/8 Rule: - -118766

CUT \& FILL YOLUMES

Positive Volume [Cuts]: $\quad 454.758$

Negative Volume [Fills]: $\quad 119232$

Cuts minus Fills: $\quad-118778$

\section{AREAS}

\section{Positive Planar Area}

(Upper above Lower):

Negative Planar Area

(Lower above Upper):

Blanked Planar Area: 0

Total Planar Area: $\quad 9800$

Positive Surface Area

(Upper above Lower):

Negative Surface Area

(Lower above Upper):

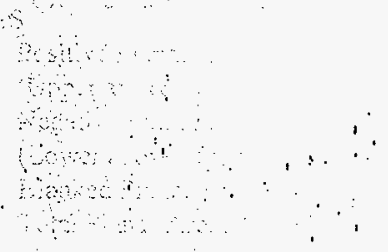


VOLUME COMPUTATIONS

UPPER SURFACE

Grid File:

C:AXTF/AX7/AX7.GRD

Rows: 0 to 32766

Cols: 0 to 32766

Grid size as read: $\quad 50$ cols by 50 rows

Delta X: $\quad 0.816327$

Delta Y: “ $\quad 0.816327$

X-Range: $\quad 595$ to 635

Y-Range: $\quad 700$ to 740

Z-Range: $\quad-16.9266$ to 0.576796

LOWER SURFACE

Level Surface defined by $Z=0$

\section{VOLUMES}

Approximated Volume by

Trapezoidal Rule: $\quad-7671.59$

Simpson's Rule: ... $\quad-7674.16$

Simpson's 3/8 Rule: -7674.28

CUT \& FILL VOLUMES

positive Volume [Cuts]: $\quad .22 .8273$

Negative Volume [Fills]: $\quad \mathbf{7 6 9 4 . 4 2}$

Cuts minus Fills: $\quad-7671.59$

\section{AREAS}

Positive Planar Area

(Upper above Lower):

Negative Planar Area

(Lowerabove Upper):

Blanked Planar Area: 0

Total Planar Area: 1600

Positive Surface Area

(Upper above Lower):

Negative Surface Area.

(Lower above Upper):

93.8422

1506.16

1600

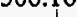

95.2003

2045.91 
VOLUME COMPUTATIONS

UPPER SURFACE

Grid File: C:/AXTF/AX8/AX8.GRD '

Rows: 0 to 32766

Cols: 0 to 32766

Grid size as read: $\quad 50$ cols by 50 rows

Delta X: $\quad 0.816327$

Delta: Y 0.816327

$X$-Range: $\quad 595$ to 635

Y-Range: $\quad 640$ to 680

Z-Range: $\quad-44.5405$ to 0.83372

LOWER SURFACE

Level Surface defined by $Z=0$

VOLUMES

Approximated Volume by

Trapezoidal Rule: $\quad-23969.5$

Simpson's Rule: $\quad-23973.5$

Simpson's 3/8 Rule: -23974.2

CUT \& FIL VOLUMES

Positive Volume [Cuts] $\ldots \quad 56.5943$

Negative Volume [Fills]: $\quad 24027.2$

Cuts minus Fills: $\quad-23970.6$

AREAS

V Positive Planar Area

(Upper above Lower):

Negative Planar Area

(Lower above Upper):

Blanked Planar Area: 0

Total Planar Area: $\quad 1600$

169.985

1430.02

Positive Surface Area

(Upper above Lower):

Negative Surface Area

(Lower above Upper):

174.438

3572.94 


\section{VOLUME COMPUTATIONS}

UPPER SURFACE

Grid File: $\quad$ C:/AXTF/AX9/AX9.GRD

Rows: 0 to 32766

Cols: 0 to 32766

Grid size as read:

Delta X: $\quad 0.816327$

Delta Y: $\quad 0.612245$

$X$-Range: $\quad 435$ to 475

Y-Range: $\quad 760$ to 790

Z-Range: $\quad-23.0326$ to 0.960121

\section{LOWER SURFACE}

Level Surface defined by $Z=0$

\section{VOLUMES}

Approximated Volume by

Trapezoidal Rule: $\quad-9073.25$

Simpson's Rule: $\quad-9076.56$

Simpson's 3/8 Rule -9075.96

CUT \& FILL YOLUMES

Positive Volume [Cuts]: $\quad 92.4404$

Negative Volume [Fills]: $\quad 9165.69$

Cuts minus Fills: $\quad-9073.25$

\section{AREAS}

\section{Positive Planar Area}

(Upper above Lower):

Negative Planar Area

(Lower above Upper):

Blanked Planar Area: 0

Total Planar Area: $\quad 1200$

Positive Surface Area:

(Upper above Lower):

Negative Surface Area

(Lower above Upper): 
VOLUME COMPUTATIONS

UPPER SURFACE

Grid File: $\quad$ C:/AXTF/AX10/AX10.GRD

Rows: 0 to 32766

Cols: 0 to 32766

Grid size as read: 50 cols by 50 rows

DeltaX: : $\quad 0.714286$

Delta Y: $\quad 0.612245$

$X$-Range: $\quad 405$ to 440

Y-Range: $\quad 730$ to 760

Z-Range: $\quad-11.0765$ to 0.319953

LOWER SURFACE

Level-Surface defined by $Z=0$

VOLUMES

Approximated Volume by

Trapezoidal Rule: $\quad-4293.29$

Simpson's Rule: $\quad-4295.77$

Simpson's 3/8 Rule 4295.31

CUT \& FILL VOLUMES

Positive Volume [Cuts]: $\quad 21.8042$

Negative Volume [Fills]: $\quad 4315.1$

Cuts minus Fills: $\quad-4293.29$

AREAS

Positive Planar Area

(Upper above Lower):

170.661

Negative Planar Area

(Lower above Upper):

Blanked Planar Area: 0

Total Planar Area: 1050

879.339

Positive Surface Area

(Upper above Lower):

Negative Surface Area

(Lower above Upper):

171.396

1224

FAtt-11 
VOLUME COMPUTATIONS

UPPER SURFACE

Grid File:

C:/AXTF/AXI I/AXII.GRD

Rows: 0 to 32766

Cols: 0 to 32766

Grid size as read: $\quad 50$ cols by 50 rows

Delta X: $\quad 0.612245$

Delta Y: $\quad 0.612245$

X-Range: $\quad 415$ to 445

Y-Range: $\quad 680$ to 710

Z-Range: $\quad-26.2546$ to 1.16173

LOWER SURFACE

Level Surface defined by $Z=0$

VOLUMES

Approximated Volume by

Trapezoidal Rule: $\quad-7431.52$

Simpson's Rule: $\quad-7434.56$

Simpson's 3/8 Rule: $\quad-7434.28$

CUT \& FILL VOLUMES

Positive Volume [Cuts]: $\quad 19.247$

Negative Volume [Fills]: $\quad 7450.77$

Cuts minus Fills: $\quad-7431.52$

\section{AREAS}

Positive Planar Area

(Upper above Lower):

Negative Planar Area

(Lower above Upper):

Blanked Planar Area: 0

Total Planar Area: $\quad 900$

Positive Surface Area

(Upper above Lower):

Negative Surface Area

(Lower above Upper): 


\section{VOLUME COMPUTATIONS}

\section{UPPER SURFACE}

Grid File: $\quad$ C:/AXTF/AX12/AX12.GRD

Rows: 0 to 32766

Cols: 0 to 32766

Grid size as read: $\quad 50$ cols by 50 rows

Delta X: $\quad 0.612245$

Delta Y: $\quad 0.612245$

$X$-Range: $\quad 475$ to 505

Y-Range: $\quad 570$ to 600

Z-Range: $\quad-22.313$ to 0.0773491

\section{LOWER SURFACE}

Level Surface defined by $Z=0$

\section{VOLUMES}

MES

Approximated Volume by

Trapezoidal Rule:

Simpson's Rule:

$-7771.15$

Simpson's 3/8 Rule 7774.34

CUT \& FIL YOLUMES

Positive Volume [Cuts]: $\quad 0.0185393$

Negative Volume [Fills]: $\quad .7771 .17$

Cuts minus Fills: $\quad-\mathbf{7 7 7 1 . 1 5}$

\section{AREAS}

Positive Planar Area

(Upper above Lower):

Negative Planar Area

(Lower above Upper):

Blanked Planar Area: 0

Total Planar Area: $\quad 900$

Bositive Surface Area

(Upper above Lower):

Negative Surface Area

(Lower above Upper):

\subsection{4}

899.176 


\section{VOLUME COMPUTATIONS}

UPPER SURFAC̣E

Grid File: C:/AXTF/AX13/AX13.GRD

Rows: 0 to 32766

Cols: 0 to 32766

Grid size as read: 50 cols by 50 rows

Delta X: $\quad 0.612245$

Delta Y: $\quad 0.612245$

X-Range: $\quad 525$ to 555

Y-Range: $\quad 570$ to 600

Z-Range: $\quad-22.7918$ to 0.290993

LOWER SURFACE

Level: Surface defined by $Z=0$

VOLUMES

Approximated Volume by

Trapezoidal Rule: $\quad-8578.61$

Simpson's Rule: . . $\quad-8582.41$

Simpson's 3/8 Rule: $\quad-8582.03$

CUT \& FILL VOLUMES

Positive Volume [Cuts]: $\quad 0.42165$

Negative Volume [Fills]: $\quad 8579.03$

Cuts minus Fills: $\quad-8578.61$

AREAS

Positive Planar Area

(Upper above Lower): $\quad 6.75232$

Negative Planar Area

(Lower above Upper):

893.248

Blanked Planar Area: 0

Total Planar Area: $\quad 900$

Positive Surface Area

(Upper above Lower):

Negative Surface Area

(Lower above Upper):

7.56796

1877.02 


\section{DISTRIBUTION SHEET}

\begin{tabular}{|c|c|c|c|c|c|}
\hline & \multirow{2}{*}{\multicolumn{3}{|c|}{$\begin{array}{l}\text { From } \\
\text { D. L. BECKER }\end{array}$}} & \multicolumn{2}{|l|}{ Page 1 of 1} \\
\hline DISTRIBUTION & & & & \multicolumn{2}{|c|}{ Date $12-16-97$} \\
\hline \multirow{2}{*}{\multicolumn{4}{|c|}{$\begin{array}{l}\text { Project Title/Work Order } \\
\text { HTI - AX TANK FARM WASTE INVENTORY STUDY FOR THE HANFORD TANKS } \\
\text { INITIATIVE PROJECT HWF-SD-HTI-TI-001, REV. } 0 \\
\end{array}$}} & \multicolumn{2}{|c|}{ EDT No. 622810} \\
\hline & & & & \multicolumn{2}{|l|}{ ECN No. } \\
\hline \multicolumn{2}{|c|}{ Name } & $\begin{array}{l}\text { Text } \\
\text { With All } \\
\text { Attach. }\end{array}$ & Text Only & $\begin{array}{l}\text { Attach./ } \\
\text { Appendix } \\
\text { Only }\end{array}$ & $\begin{array}{l}\text { EDT/ECN } \\
\text { Only }\end{array}$ \\
\hline
\end{tabular}

Central Files

HTI Project Files

DL Becker

AF Choho

EA Fredenburg

$C$ Henderson

AF Noonan

RW Root

JC Sonnichsen

TL Stewart

CD West

NA Homan $\begin{array}{ll}\text { BT }-07 & X \\ \text { H6-08 } & X\end{array}$

H6- $12 \quad X$

H6-35

H6- 12

B1-40

K9-91

$\mathrm{H} 6-12$

H6-26

K9-69

S7-53

H6-25 $x$
$x$
$x$
$x$
$x$
$x$
$x$
$X$
$x$
$x$
$x$
$x$ 
